

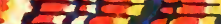

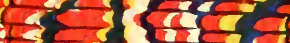

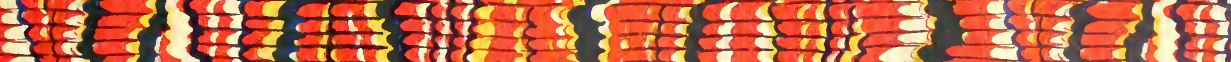
1 19

(U)

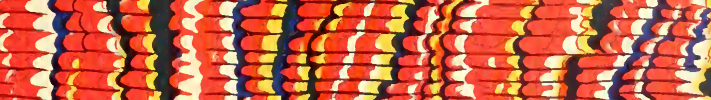

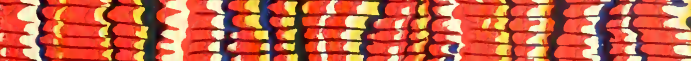

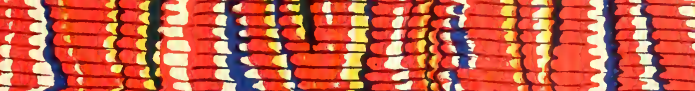

(1.) $\}^{2}=y^{2}$

What

(1)

1)

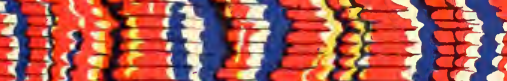

$4125\}^{2}$

(1) 11

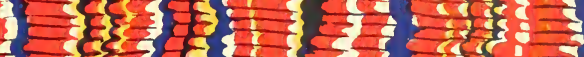

,

$\xi-\frac{1}{4}$

$+\frac{4}{2}+2$

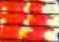

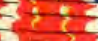

I

int

.

Int

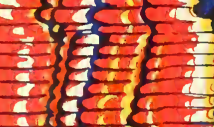

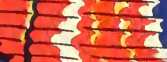

$\sum_{2}$

$\left(4 \frac{25}{2+5}\right.$

空

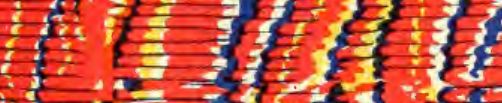

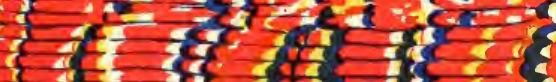

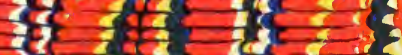

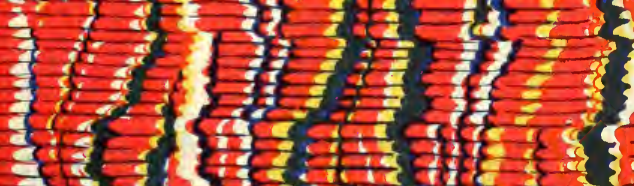

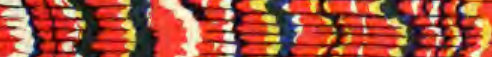

$\operatorname{lic}^{2}$ a

$\frac{\pi}{4}$

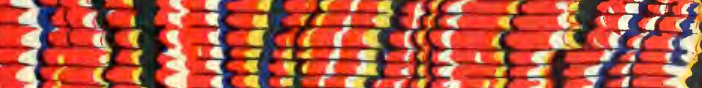

1) 12

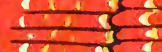

(t)

I :

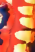

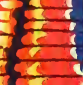

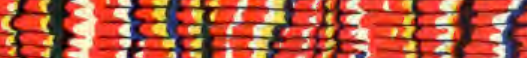

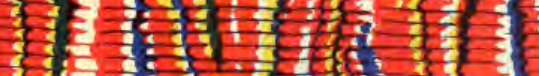

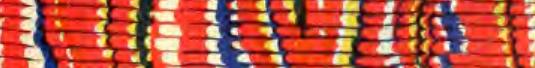

I)

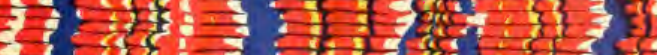

1. I)

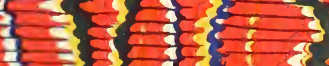

10

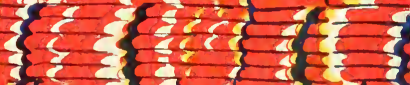

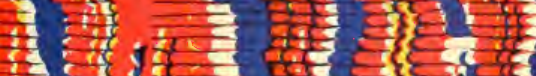

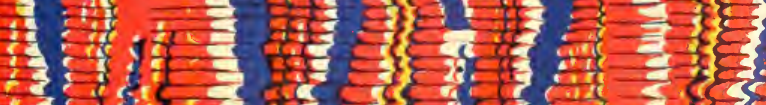

3) 







\title{
TRANSACTIONS
}

OF

\section{THE ZOOLOGICAL SOCIETY OF LONDON.}

Vol. XVII.-PART 1.

\author{
LONDON: \\ PRINTED FOR THE SOCIE'T', \\ SULD AT THEIR HOUSE IN HANOVER-SQUARE; \\ AND BY MESSRS. LONGMANS, GREEN, ANI CO., PATERNOSTER-ROW: \\ August 1903. \\ Price 30 s.
}




\title{
TRANSACTIONS OF THE ZOOLOGICAL SOCIETY OF LONDON.
}

\author{
To Fellows. To the Public. \\ \& s. d. $\quad \& s . d$. \\ VOLUME \\ I. (1833-1835, containing 59 Plates) . . Price 3136 . . . 418 (3)

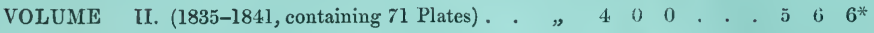

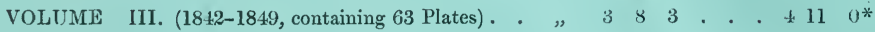 \\ VOLUME IV. (1851-1862, containing 77 Plates). . $\quad " \quad 6 \quad \begin{array}{llllllll} & 2 & 0 & . & . & 8 & 2 & 6\end{array}$ \\ VOLUME V. (1862-1866, containing 67 Plates). . " $\quad \begin{array}{llllllllll} & 5 & 4 & 3 & . & 6 & 19 & 0\end{array}$

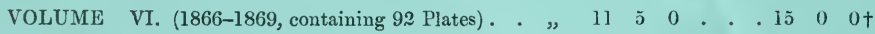 \\ VOLUME VII. (1869-1872, containing 73 Plates) . „ " $10+0$. . $13120+$ \\ VOLUME VIII. (1872-1874, containing 82 Plates). . $\quad \begin{array}{llllllllll} & 9 & 8 & 3 & . & . & 12 & 11 & 0\end{array}$

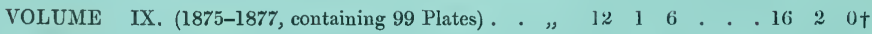 \\ VOLUME X. (1877-1879, coutaining 95 Plates). . " $10 \begin{array}{lllllllll}1 & 0 & 3 & . & 13 & 7 & 0\end{array}$ \\ GENERAL INDEX, Vols. I. to X. (1833-1879) . „ $\quad 0 \quad 7 \quad 6 \quad$. . . 010 \\ VOLUME XI. (1880-1885, containing 97 Plates). . ” $\quad$ y $12 \quad 0 \quad . \quad .12160$ \\ VOLUME XII. (1886-1890, containing 65 Plates) . . „ $\begin{array}{lllllllllll}5 & 8 & 0 & . & . & . & 7 & 4 & 0\end{array}$ \\ VOLUME XIII. (1891-1895, containing 62 Plates) . . „ $\quad \begin{array}{lllllllll}6 & 8 & 3 & . & 8 & 11 & 0\end{array}$ \\ * No copies of these volumes remain in stock. \\ † Only complete copies of these volumes are left in stock.
}



genus so that even a tyro could recognize them, and when there is no good dividingline, I cannot see that any object is gained by attempting to split up the genus. Mr. de Nicéville has suggested spelling the word "Arkopala" with two " $r$ "s," but, according to the strict canon, I prefer to leave it as it was spelt at its first institution.

The section dealing with this group in de Nicéville's work, already referred to, is by far the most valuable treatise we have, but there are so many extra-Indian species and so much material has been received since the publication of that book, the descriptions of which are seattered throughout many periodicals, whilst a good many new ones appear in this monograph, that the present seems an appropriate time to gather up these fragments and present them as a whole for the student.

Witl the exception of one or two species found in China and Japan and in some of the Pacific Islands, the whole group is confined to the Indo-Malayan region, in which I include $\mathrm{X}$. Australia: the insects appear to be confined, to a very large extent, to forest districts-de Nicérille says they seldom or never go down to streams for moisture, neither do flowers attract them; and the only way to collect them is to beat the bushes and catch them as they fly up; their flight is rapid but always short. In the present paper I have described a dozen new forms, whilst in 1896 I described thirteen new species in the 'Proceedings' of this Society, and I am figuring a considerable number of species that are in an unsatisfactory and doubtful condition.
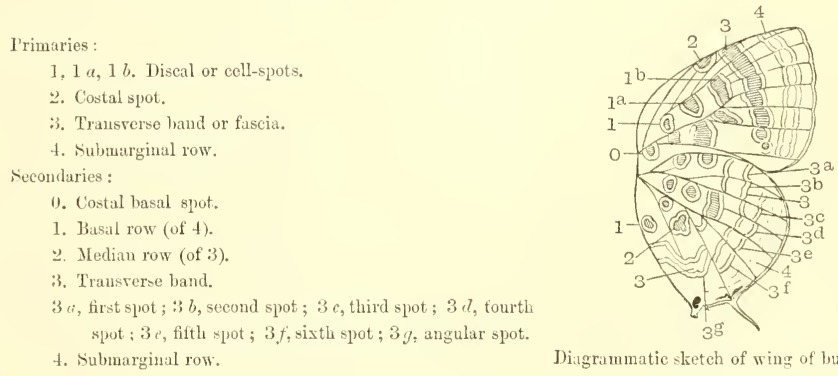

Diagrammatic sketch of wing of butterty of the genus Aitropalu.

When I undertook this work I har no idea that it would be so heary, and I have to thank mauy entomologists for valuable help. My most hearty thanks are due to Mr. de Nicéville (whose death I deeply regret and in whom India loses a very valuable observer) and to the late Dr. Staudinger-the former having sent me from India the whole of his valuable collection of this group, including all his types, whilst my old 
friend Dr. Staudinger likewise sent me the most important portion of his collection; these two alone furnished me with considerably over 2000 specimens, without which my task would have been well nigh impossible, for, with species so closely related as are many of these, it is extremely difficult to differentiate them without the types, especially when they are not described on the same plan. I have therefore in this revision adopted a uniform plan of description for the genus Arhopala, which will be easily understood on reference to the accompanying figure (Text-fig., p. 2). I have further examined nearly all the most important collections in the kingdom, and through the kindness of Herr Georg semper, who sent me all his Philippine specimens, I have been able to examine this valuable collection, so that my grateful thanks are due to him, as also to many other entomologists both on the Continent and at home; and I would specially thank Mr. Hamilton Druce, who has helped me frequently on various difficult points.

The genitalia have had my careful attention, and have often proved a real help in settling the specific value of certain species, especially in the green division of the genus Ailopalı. The subgroups, as a rule, follow the main lines of a certain pattern, and in all cases that $I$ am aware of they have a definite specific value.

\section{Surexpra Moore.}

Suremdra Moore, Proe. Zool. Soc. Lond. 1878, p. 835, et 1879, p. 112 ; id. Lep. Cey. vol. i. p. 112 (1881); de Nicéville, Butt. Ind. vol. iii. p. 218 (1890).

Both wings short and broad. Primaries with the costa evenly arched, more strongly in the female, apex acute. Pusterior margin excavated below the apex, then strongly convex, especially so in the female. Inner margin waved: costal nervure ending about the apex of the cell; second subcostal nervule with its base midway between the first and upper discoidal; third subcostal short, rising nearer the apex of the wing than the cell; discocellular nervules upright, concave, the middle rising from the upper discridal close to its base and rather shorter than the lower, submedian nervure straight. Secondaries with the costa strongly arched at the base, then almost straight in the male, but slightly arched in the female; posterior margin evenly rounded to the tail, then deeply excavated and oblique to the lobe, but in the female it is excavated up to the outer tail; abdominal margin excavated above the lobe, then rounded; first subcostal nervule rising somewhat near the apex of the cell; discocllular nervules with a slight oblique tendency outwards, straight; the second median nersule rises just at the lower end of the cell; submedian nervure straight, internal nervure straight, then strongly arched. The male has a shortish tail at the end of the first median nervule. The female has likewise, and in addition has another at the end of the second median nervule. Antennæ of molerate length; eyes smooth; palpi long, slender; legs short.

I have been unabie to trace any record of the life-history of any species of this genus, but Mr. Doherty was apparently acquainted with their eggrs, for he writes 
(J. A. S. B. vol. Iviii. pt. 2, p. 409, 1859) that the genus Surendra Moore and a number of species of Arhopala have hemispherical eggs covered with white globular tubercles and triangular reticulations, six of which radiate from each tubercle. De Nicéville says (Butt. India, vol. iii. p. 220) "that Mr. P. W. Mackinnon has seen the female of S.quercetorum laying eggs on a species of mimosa in the Dehra Dun."

The genitalia in this genus are more of the usual "Lycana" shape, the tegumen heing less ample. The hooks, however, are short and stout, whilst the clasps are not so reduced as in the genus Aikopala. The penis is long and slencler, with the extremity slightly extended (see Plate IV. fig. 1).

After examining a very considerable series of this genus (nearly two hundred are now before me, and I must have examined nearly double that number) $I$ find it is quite impossible to retain the species described from India, Ceylon, and the Andaman Isles; they are, without doubt, one and the same variable species, viz. S. quercetorum Moore, and I believe that this name should also give way to S. vivarna Horsfield, but I have not sufficient material from Java or Singapore to decide, and I therefore treat them as distinct for the present. In a hundred specimens now lying before me I cannot find one dividing-line, the ground-colour of the males ranging from a bright purplish blue, extending over the greater part of the primaries, to an exceedingly dull violet of small extent; the pattern of the mulerside varies likewise, often tending to disappear, these features obtaining in specinens from the same neighbourhood. Then as to the females, Andaman specimens (as also the Javan $S$. vivarna) are entirely dull warm brown; but I have several specimens from the Khasia Hills that are quite iudistinguishable from them, whilst from this locality I have also the common form showing the slightly paler discal patch, and one at least which is quite as pale as the average Ceylonese form named by Mr. Moore discalis. The outline of the wings seems equally liable to variation, for I have males from the Khasias with most decided "hook-tips" and others with an almost straight outer margin.

Turning now to the amisena group, I find, on careful comparison, that Staudinger's types of palowna (which I lave before me) agree precisely with Hewitson's type of amisena, the tail being but little different, but much exaggerated in Hewitson's drawing. Florimel of Doherty has no tail, and therefore I retain it as distinct; it is also bright and has a somewhat different underside. Stimula de Nicéville is, without doubt, referable to $S$. florimel Doherty, as there is no difference except in the larger size of de Nicéville's forms.

SUREXDRA QUERCETORUM (Moore).

Amblypodia quercetorm Moore, Horsfield and Moore, Cat. Lep. Mus. E.I.C. vol. i. p. 42. n. 63, pl. i $a$. fig. 7, ơ (1857); Hewitson, Cat. Lycænida B.M. p. 14 (1862); id. Ill. Diurn. Lep., Lye. p. $14(1865)$. 
Amblypodia rivarna IIewitson (nec Horsfield), Cat. Lyc. B.M. pl. vii. fig. 76 , ơ (1862).

Surendra discalis Moore, Proe. Zool. Soc. Lond. 1879, p. 142; id. Lep. Cey. rol, i. p. 112, pl. sliv. figs. $1 \delta^{\circ}, 1 a$ ㅇ $(1881)$.

Surendra latimargo Mloore, Proe. Zool. Soe. Lond. 1579, p. 142.

Surendra quercetorum var. latimurgo Wood-Mason and de Nicéville, J. A. S. B. vol. xlix. pt. 2, p. 235 (1880).

Surendra biplagiata Butler, Proc. Zool. Soc. Lond. 1853, p. 117. pl. xriv. fig. 12, đ.

Amblypodia quercetorum Staudinger, Ex. Sclmett. p. 281, pl. xcri. (1888).

Surendre quercetorum MLoore, Proc. Zool. Soc. Lond. 158:, p. 251; Doherty, J. A. S. B. vol. lv. pt. 2, p. $130(1886)$.

Surendra quercetorum de Nicéville, Butt. Ind. vol. iii. p. 220 (1890).

Surendra biplagiata de Nieéville, op. cit. p. ․:21.

Surendra disculis and S. latimargo de Nicévilie, op. cit. p. 222.

Hab. Sylhet; N. India; Kangra Valley; Bagheswar; Lower Ramganga; Gori and Kali Valleys; Kumáun; Madras; Ceylon; Andamans; Burma; Issam; Kaslmir.

Expanse, o 2s-34, o $36-39 \mathrm{~mm}$.

o. Upperside: both wings riolet-blue; primaries with broad black costa, broader posterior margin, and apex black from the termination of the cell; secondaries with the blue extending only in the median area and just into the cell. Tail tipped with white; lobe rery much produced. Underside: both wings greyish brown: primaries with an obscure dark dash in the cell and a narrow elongated spot at the close, two other dark dots on the costa, a dark, very irregular, transverse line midway between the end of the cell and the posterior margin from the costa to the submedian nervure, beyond which is a row of small very dark dots, sometimes very obscure: secondaries with a white dot below the costal nervure near the base, beneath which is an obseure, dark, jagged, interrupted line ; from the apex to the centre of the abdominal margin is an obscure band of dark shading, in which is an irregular whitish-edged fascia from the costa (before the apex) to the abdominal margin; a submarginal row of dark spots, sometimes formed into a lunulated line; lobe-spot very dark redlish brown; anal area sprinkled with greyish scales.

ㅇ. Upperside: both wings entirely dark brown, with a pale dash beyond the cell in the primaries. Tails edged with white. Underside exactly as in the male, but with all the markings sharper.

On examining very carefully a large series of this species, I find it is quite impossible' for me to differentiate biplagiata Butler and latimargo Moore from Moore's original species; it is so very variable everywhere that it is useless retaining these names. The same remark applies with regard to discalis Moore: this is a mere aberration which is quite inconstant; in some specimens the ochreous patch is very prominent, in others less so, and I have others from the same locality in which there is no trace of it. 
Strexpra tivaria (Horsfield). (Plate I. fig. 6.)

Amblypodia virarna Horsfield, Cat. Lep. Mus. E.I.C. p. 99. n. 31 (1839) ; Hewitson, Cat. Lỵcenidre

33.M. p. 13. n, 61, pl. vii. figs. 73,77 \% , 75 \& $(1862)$.

Surendra vivarna de Nicéville, Butt. India, vol. iii. p. 221 (1890).

Ilab. Java; Sumatra.

Expanse, o 29-33, ㅇ $31-34 \mathrm{~mm}$.

o. Upperside: both wings rather intense deep blue: primaries with the costa broadly, posterior margin more broadly, apex still more broadly black; secondaries with the blue limited to just over the median aren, the rest of the wings black. Tails two, black, the longer one white-tipped. Underside: both wings very dark greyish brown: primaries with an obscure dark dot near the centre of the cell and a small dash closing it, costa with three dark dots; transverse blackish line curved irregularly and scalloped from the costa to the submedian nervure, a submarginal row of blackish dots, margin obscurely dark, internal area quite pale: secondaries with a small white spot about one-third along the costal nervure, below which is an obscure dark short dash in the cell; from two-thirds along the costa to the middle of the abdominal margin is a narrow, indefinite, obscure band of dark shading edged externally and sharply with white, a submarginal row of dark spots forming an aluost lunular line; on each side of the long tail is a slight grey scaling.

q. Upperside: both wings entirely dark brown. Underside as in the male, but decidedly paler.

In this species the outer margin is much produced in the median area, both in the male as well as in the female, but is a somewhat unusual feature in the former, whilst in the female the tij) is much less produced outwards, forming less of a hook-tip.

Sunindra amisena (Hewitson). (Plate I. figs. 3 o , 4 \& 5 ㅇ ; Plate IV. figs. 1 \& 1 a.) Amblypodia amisena Hewitson, Cat. Lycenide B.MI. 1. 13, pl. vii. figs. 7t-78, of (1862); Kheil, Rhop. Ins. Nias, p. 33. n. 123 (1881).

Rapala amisene Distant, Rhop. Malay. p. 277. n. 1, pl. xxiii. fig. 13, б (1885).

Surendra amisena Doherty, J. A. S. B. vol. lviii. pt. 2, p. 424 (1889).

Amblypodia yelowna Staudinger, 1ris, vol. ii. p. 131, pl. ii. fig. 3 (1889).

Surendra amisena de Nicéville, Butt. Ind, vol, iii. p. 22:2 (1890).

Surendra pralowne Druce, Proe. Zool. Soc. Lond. 1895, p. 588.

Ilab. Sumatra; Borneo; Palawan; Balabac; Nias; Malacea.

Expanse, of 40-43, ㅇ $39-45 \mathrm{~mm}$.

o. Upperside: both wings dull violet to purplish blue: primaries with apical area very broadly dark brown, tapering rery narrowly to the anal angle and less narrowly on the costa: secondaries with blne confined within the upper discoidal and submedian nervures; posterior margin narrowly brown. Underside: both wings warm slight!y rufous brown. Primaries with the least trace of a most obscure spot 
in the cell and an equally obseure line closing the cell, often entirely obsolete; transverse band dark, sharply defined, with its centre curved ontwards, thus giving it somewhat the shape of a strung bow, the line slightly interrupted at the nervures; a submarginal row of moderately distinct dark dots; internal area pale. Secondaries with a white spot below the costal nervure; a third along it, below which is an obseure, irregular, short line aeross the eell; transverse line not far beyond the cell, very irregular, composed of short, white, interrupted marks from the eosta (a third from the apex) to near the end of the internal nervure; these white marks have all a dark diffused interual shading; the dark submarginal row is lunulax, interrupted at each nervure and edged interually with whitish or palely; the anal angle has more or less metallic scaling, oceasionally entirely wanting, often very slight, but sometimes eonsisting of two large patehes of bluish scales with a small spot at the extremity of the fold. 'The tail of the type specimens is very short, the margin scalloped on each sicle of it; this is very variable, however. I have before me some without any tails at all which appear from several localities with the tailed form; then I have others in which the tail is reduced to a short tooth-like excrescence.

․ Upperside: both wings glossed all over with slightly lustrous dull violet-manve, which makes the species imuediately recognizable from all others of the genus. I have a second form which is entirely glossed with steel-blue; both have precisely the same underside as the male just deseribed. This is evidently a case of a dimorphic female.

Dr. Standinger's types of $S$. palowna are before mc, and they are absolntely the same as the specimen labelled amisenu in Hewitson's collection, each having slight tails. Mr. Drnee is eorreet in saying, in his Bornean paper (P. Z. S. 1895, p. 5ns), " that the charaeters he mentions, of the tails, will be found to be insuficient to separate amisene and palowna."

Hewitson's figures show the tails very considerably longer than appears in any speeimen that I have seen. I hope that my figures of both forms of the female of this species will prevent further confusion.

\section{SuRENDR Florimel Doherty.}

Surendra florimel Doherty, J. A. S. B. vol. 1viii. pt. 2, p. 4:24, pl. xxiii. figs. 17 J, 4 \& (1859); de Nicéville, Butt. India, vol. iii. p. 2:2:3 (1 590$)$.

Surendra stimulu de Nicéville, Journ. Bomb. Nat. Hist. Soc. vol. ix. pl. O. fig. 23 (1895).

IIcb. Wagung, Tavoy District; Burma; Sumatra; Java.

Expanse, of \& $8,35-39 \mathrm{~mm}$.

c. Above rich purple-blue from the costal vein to the hind margin, the biue area outwardly angled at the upper median rein, and oecupying nearly halt of the 
fore wing; on the lind wing it extends from just below the lower subcostal to the submedian vein, leaving the upper part of the cell dark; a narrow black marginal line. Below the ground is light fuscous brown, as in amisena, but with the cell and disc of the fore wing much darker and the basal and apical half of the hind wing deep violet-brown. Fore wing with a short oblique dark streak in the middle of the cell, a larger one across its end, and one or two costal streaks; a transverse discal line of joined lunules (separated in amisena) from the second subcostal to below the lower median, projecting ontwardly below the lower radial vein; apex widely, and onter margin narrowly, pale fuscous. Hind wing with the transverse discal fascia consisting of a broken dull silvery line on a deep brown ground, an obscure, onter, discal, transverse band, pale on the dark apical, and dark on the pale abclominal ground; an obscure metallic patch in the lower median space.

․ Above dull brown, a slightly paler area in the middle of the disc. Below the dark area of the fore wing is confined to the neighbourhood of the median spaces on the disc, that of the hind wing to a band across the wing from the apex to the hind margin, crossing the end of the cell; a distinct whitish spot basally between the costal and the subcostal veins; the inner transverse line united, crossing the dark area subapically; the outer one consisting of pale lumules, bordered, especially outwardly, by a dark band in which there are two dark subapical spots, the second larger.

This species has the hind wing strongly angled at the end of the middle median vein, and quite straight thence to the anal angle; there is no trace of tails or lobes. The fore wing is not faleate in either sex. The egg and venation are as in amisena and queicetorum. It is a very distinct species, ancl the male is very richly coloured.

One male and several females taken on the pass near Wagung, Tavoy District, at 1500 feet altitude.

S. stimula de Nicérille, the type of which is before me, is, without doubt, only a large example of this species.

Inaota Moore.

Iraota Moore, Lep. Cey. vol. i. p. 101 (1881); Distant, Rhop. Malay. p. 253 (1885̃); de Nicéville, Butt. India, vol. iii. p. 213 (1890).

Wings less ample, but strong. Primaries with the costa curved at the base, excarated slightly in the mirlde, then straight; apex rounded; outer margin convex at apex, then concave; inner margin straight. Costal nervure of medium length, ending about the apex of the discoidal cell: first subcostal nervule curved upwards near the base; second subcostal rising midway between the first and the upper discoidal nervule; third subcostal long, from the subcostal nervure nearer to the apex of the wing than to the origin of the upper discoidal; fourth subcostal (not present in the female) rery short, rising close to the apex of the wing; the end of the 
subcostal nervure terminates just below the apex of the wing in the male, but at the apex in the female; the lower cliscoidal nervule rises from the upper discoidal not very far from the origin of the latter; the upper and middle discocellular nervules absent; lower discocellnlar mpright, slightly concave, rising directly after the origin of the discoidal nervule; second median nervule rising just before the lower end of the cell; submedian nerrure straight. Secondaries with the costa evenly curred; the onter margin in the male is slightly scalloped and inwardly oblique, in the female rounded and decidedly scalloped; the submedian nervure is produced into a short tail, gencrally much longer in the female than in the male, sometimes with a second tail at the end of the first median nerrule in the male longer than the other-this tail is always present in the female, but is shorter; sometimes there is a third tail at the termination of the second median nervule, which is the shortest of the three. Anal lobe large and well formed. The costal nervure is curved throughout, but very strongly near the base; first subcostal, rising close to the end of the cell, is likewise curved; upper and lower discocellular nervules slightly concave and outwardly oblique, second median nervule rising near the lower end of the cell; submedian nervure slightly recurved, the internal nervure strongly recurved and long. Antenne rather long, over half the length of the costa. Eyes smooth. Palpi porrect. Thorax stont. Body fairly robust. The male has a small tuft of hairs just before the middle of the inner margin of the primaries, and a very slight glandular space between the bases of the costal and the subcostal nervures.

Larva onisciform, smooth; head small; second segment small, then increasing rapidly to the fifth, afterwards decreasing to the anal segment. Pupa smooth, humped on the thorax; abdominal segments rery broad at first, but rapidly decreasing to the tail.

De Nicéville says lıe has only taken specimens of this genus on or near the banian tree, on the leaves and small branches of which they alight. He describes the flight as very powerful and rapid, thongh the insects soon settle after being disturbed. The triangular slape and strong texture of the wings would lead one to expect that all members of the genus were powerful and rapid fliers. The genitalia are specialiserl, the tegumen being of a very simple hood-like shape (like a sun-bonnet) with long slender hooks attached very simply to its lower extremity; the lateral supports are slender and the clasps well dereloped.

Iraota timoleon (Stoll). (Plate IV. figs. 2 \& 2 a.)

Papilio timoleon Stoll, Suppl. Cramer, Pap. Ex. vol. v. pl. xxxii. figs. $4,4 d$, q (1790).

Amblypodia timoleon Horsfield and Moore, Cat. Lep. Mus. E.I.C. vol. i. p. 1H. n. 6z, pl. xii. figs. 3 larva, $3 a$ pupa (18jz); Marshall and de Nicéville, Butt. Ind. vol. i. pl. ii., larra and jupa (1882).

Iraota timoleon Moore, Proc. Zool. Soc. Lond. 1882, p. 249; Staudinger, Exot. Schmett. p. 279, pl. xevi., o (1888).

vol. XiII.-PARt I. No. 2.-August, 1903. 
Thecla nila Kollar, Hügel's Kaschmir, vol. iv. pt. 2, p. 413. n. 3, pl. iv. figs. 5, 6, ơ (1844).

Iruota timoleon de Nicéville, Butt. Ind. vol. iii. p. 215. n. 775, pl. xxvii. figs. 192 o , 193 (1890).

Hab. China; Bhutan; Kangra District; Masuri; Dahlousie ; Chumba, Dagshai, Faizabab; Julpigori; Sikkim; Cachar; Pachmarli ; Orissa; Ganjam ; Rutnagherry ; Khandala; Poona; Nilgiris (found only at low elevations).

Expanse, o 48 , 우 $48-56 \mathrm{~mm}$.

o. Upperside: both wings black: primaries with a large patch of brilliant deep lustrous azure below the cell, extending from the base across three-quarters of the wing: secondaries with a larger patch of lustrous deep azure between the upper discoidal and the submedian nervure, and extending but little into the cell, and leaving a rather broad black posterior margin; lobe brick-red, the single fairly long grey-tipper tail adjoining it. Underside: primaries blackish, with the whole of the submedian area grey, and the costa and upper half of the posterior margin broadly red; beyond the centre of the costa is an obscure pale greyish patch; a silvery-white club-shaped stripe extends rather over halfway along the upper edge of the cell, which is closed by a similar white spot; a straight, interrupted, very obscure, whitish-spotted fascia extends from the costa to the lower median nervule, the lower part of which consists of two lunular white spots, the upper part being very obscure; in the red apical area there is a trace of another short whitish-spotted row. Secondaries clouded grey-black and brown, lusted all over more or less thickly with red irrorations; from the base of the cell up to just beyond the middle of the costal nervure an irregular white patch extends which is narrowed in the middle, and also has a certain amount of red irroration therein; cell partly closed by a short white dash from the middle of the lower median nervule to the abdominal edge ; there is a very irregular whitish line, outside which are three longish red spots touching eaclı other, below which is another white stripe; there is a broadish orange patch in the middle of the posterior margin; lobe velvety red, with grey fringes.

․ Upperside : both wings brown, with two tails; the primaries only with a sublustrous violet patch. Underside as in the male, but altogether paler.

Horsfield and Moore figure the larva as onisciform and smooth, with a very small head; eecond segment largish; third and fourth each larger than its predecessor, then lecreasing evenly to the tail. Nearly one inch long. Pinkish, shading off into greenish on the sides; the terminal segments entirely green, with three rows of lateral dots. Pupa dark brown, striped with darker brown. Short and thick; head distinct; abdomen slightly constricted below the thorax, and roundish at the end.

De Nicéville $(l . c$.) writes that both $I$. timoleon and mecenas present the same apparent dimorphism in the female, and he continues: " though these two species are apparently so distinct, I loold to the opinion that breeding will probably prove them to 
be but one rariable species." The same opinion is held by Mr. W. Doherty, who writes of $I$. macenas, "an extremely variable species wherever I have found it." I think it by no means improbable that this "variability is due to seasonal eauses, and that it will hereafter be found that $I$. timoleon is the rains form and $I$. mrecencs the dry-season form of one species."

The dimorphic female referred to by de Nicéville is very curious, it being oecasionally found that some females are as brilliantly and as extensively metallic blue as the males. The prehensores are among the most simple in shape of any that I know; the tegumen is a quite plain hood, with long slenler hooks attached to the lower extremities; the lateral supports long and slight; the clasps fairly developed, bam-shaped, with square extremities whose upper corner is produced. Penis long, with the lower portion of the tip extended considerably beyond the upper half.

IraOta MaCENAS (Fabricius).

Hesperia mecenas Fabrieins, Ent. Syst. vol, iii. pt. 1, p. 271. 11. 45 (1793); Donoran, Ins.

Clina, pl. xxxis. fig. : 2, \& (1798).

Deudorix macenas Hewitson, Ill. Diurn. Lep., Lyc. p. 25. n. 27 (1863); Butl. Cat. Fab. Lep.

B.M. p. 180. no. 2 (1869).

Iraota mecenas Moore, Lep. Cer, rol. i. p. 102, pl. xl. fics. $2 *, 2 a$ f , $2 b$ larva and pupa (1981);

Doherty, J. A. S. B. vol. lv, pt. 2, p. 126. n. 123 (1886).

Deudorix timoleon Hewitson, Ili. Diurn. Lep., Lyc. pl. viii. fig. 21, f (1863).

Iraota mecenas de Nieévillc, Butt. Ind. vol, iii. p. 216 (1890).

Ilat. China; Hongkong; North India; Cẹlon; Jhulaghât; Eastern border of Kumaun; Tanna, or Nasik 1)istriet; Egntpura, or the Thul Ghat (October), Bombay ; Bhutan, Sikkim (April, November, and Decenber); Mundi, Naswin ; Dinapore; Pholahât; Calcutta; Orissa; Bangalore.

Expanse, ơ 36-48, q $42-54 \mathrm{~mm}$.

c. Upperside: both wings rery dark purplish brown, with blue patches deeper in tone than in timoteon, and perhaps rather more extensive in the primaries. Underside: both wings almost precisely as in timoleon, but not quite so dark, anil with no silvery-white patch below the costa of the secondaries; the ontline of this patch is, however, quite distinct as a rule.

ㅇ. Upperside: both nings brown, with a violet or purplish patch of eonsiderable extent on the primaries, whilst on the secondaries this colour is reduced almost to the lisc. This species, like timolcon, has another occasional form of the female just like the male, and I conclude it was from one of this form that Mr. Moore described the species with the male and female similar in colour. The common torm is as deseriber! here. I have one specimen also in which the violet-blue colour of the primaries is reduced alnost to the discal area.

The earlier authors mixed up this and the previous species considerably, but I believ 
that de Nicéville (l. c.) has quite correctly elucidated them. This species may be known from all others by the absence of the silvery-white patch at right angles to the body, just below the costa in the secondaries. It seems to obtain in precisely the same district as timoleon. It would be an interesting life-history to work out, and so prove the correctness of de Nicéville's theory that it is the dry-season form of that species.

Iraota Rochana (Horsfield).

Amblypodia rochana Horsfield, Cat. Lep. Mus. E.I.C. p. 108. n. 40 (1829) ; Horsfield and Moore, Cat. Lep. Mus. E.I.C. vol. i. p. 44. n. 68, pl. i a. fig. 10, ठ (185\%).

Iraota rochana Moore, Journ. Linn. Soc. Lond., Zool. vol. xxi. p. 43 (1886); de Nicéville, Butt.

Ind, vol. iii. p. 217. n. 777 (1890); Druce, Proc. Zool. Soc. Lond. 1895, p. 587;

de Nicéville aud Martin, J. A. S. B. vol. lxiv. pt. 2, p. 463 . n. 383 (1895).

Thecla timoleon Boisduval (nec Stoll), Sp. Gén, vol. i. pl. xxii. fig. 4, q (1836).

Deudorix timoleon Drucc, P. Z. S. Lond. 1873, p. 352.

Iraota boswelliana Distant, Rhop. Malay. p. 258. n. 1, pl. xxii. fig. 23, $q$ (1885); Staudinger,

Exot. Schmett. p. 279, pl. xevi., 우 (1888).

Ilab. Mergui; Java, Borneo (Kina Balu and Labnan); Penang; Singapore; Philippines (Felder); Sumatra.

Expanse, of $38-44$, ㅇ $43-50 \mathrm{~mm}$.

ठ. Upperside: both wings brownish black, with the blue patches of a pale metallic azure, not the deep blue of the previons two species. Two tails, tipped with white, one at the lobe and one from the end of the lower median nervule; there is also a tooth-like excrescence at the end of the second median nervule. Underside: primaries dark grey with the internal margin quite pale; a silvery-white stripe along the upper discoidal nervure terminating a third before the end of the cell, which is closed by a likecoloured spot, beyond which is a curved row of three silvery-white spots, the lowest being the most outward and forming at the same time the uppermost of a row of three straight, very oblique (inwardly), white spots ; the ground beyond the curved row is red up to the submarginal row of white spots, which row is curved ontwards in the centre, while beyond this the margin is slightly rufous, and the costal area is also somewhat rufous. Secondaries with the basal half brightly rufous, the extreme basal costa being shortly white; from the base there is a very broad band of creamy silvery touching the costal nervure at and beyond its middle, which sends a creamy stripe to the upper median nervule, thus closing the cell; a toothed whitish stripe runs from the base of the second median nervule to the upper part of the abdominal margin. This rufous area is edged by an irregular, somewhat interrupted, curved stripe of whitish, on the onter margin of which is a row of four or tive very deep red, lunular, small spots extending as an interrupted red stripe to the abdominal edge, beyond which is a broad band of neutral grey tapering and narrowing towards the costa and ending in a small red patch; outside this is a marginal row of spots, the lobe-spot and three beyond it being 
relvety-black, while above these the other four are red, the central three being the smallest; all are entirely encircled with white, and the spot next that on the lobe is almost entirely obsolete with superimposed submetallic bluish-grey scales.

ㅇ. Upperside: both wings of a somewhat dark golden brown, darker at the extremities, with three distinct white-tipped tails, the upper one being short and broad; lobe-spot black. I have one specimen before me with a trace of violet scaling on both wings; the brown line in this specimen is quite dark all over. Underside: both wings like the male, but all the silvery-white spots and markings are very much enlarged and intensified throughout, and the submedian area and internal margin in the primaries are whitish, whilst the broad tapering band of the secondaries is ochreous rather than grey.

In the specimens with riolet scaling on the upperside the costal and subcostal margin of the primaries is orange rather than red, and in the other specimens there is a tendency towards this tone of colour. This species has two tails in the male and three in the female. It may casily be distinguished from the preceding species by the distinct black spots in the anal area, the greater extent of white in the secondaries, and by the pale delicate brown subcostal band preceding the blick anal spots.

Inıota laz.seesa (Felder). (Plate I. fig. 2, 오)

Myrima lazarena, Felder, Wien. ent. Monats, vi. p. 293.

Iraota luzarena, Semper, Sehmett. Philip. Ins. Bd. v. p. 195.

IIab. Borneo; Celebes; Philippine Islands (Coll. Semper).

Expanse, of \& , $51 \mathrm{~mm}$.

o. Uppersicle : both wings brownish black, with a patch of brilliant metallic emeraldgreen scales, that on the primaries occupying the subrliscal area, but only extending slightly over the submedian nervure, and bnt little beyond the cell; on the secondarics these scales are more extensive, extending in a line down the median nervure, increasing slightly towarls the end of the cell, where it suddenly expands and occupies a good part of the median area; three tails, tipped with white; lobe well cleveloped, with a black eye-spot. Underside: both wings greyish brown: primaries with a white slightly increasing streak occupying nearly the full length of the cell, beyond which is a white spot; transverse band composed of five spots, the first three inclined very ubliquely outwards, the first, nearest the costa, being very small, the fourth and fifth inclined very obliquely inwards; a narrow submarginal line of continuous spots; submedian area pale. Secondaries with a short white edging to the base of the costa, followed by a broad stripe of the ground-colour; a broadish white oblique stripe extends from the base to the apex of the costa, interrupted near the apex; in the large area of the darker ground-colour there is a horizontal irregular shortish white stripe; cell closed by a narrow white line; this dark area is edged yet lower down by 
an irregular indistinct whitish line, this is followed by a very broad paler band of the ground-colour tapering towards the apex, edged outside by a fine, irregular, white line, heyond which is a row of marginal spots, all of which are indistinct except those ndjacent to the tails, that by the first short tail being quite black, whilst the lobe-spot is intense velvety black; these are edged above, and the space between them is filled in, with a sparse scattering of submetallic green scales.

ㅇ. Upperside : both wings entirely warm darkish brown, with three tails, all whitetipped. The costal area of the secondaries is pale. Beneath, the pattern in both wings is like the male, but all the white markings are greatly accentuated and are brilliantly pearly white, and the darker ground-colour is rich reddish brown.

This species is nearest rochana Horsfield, but is very much larger, and the male has three distinct tails, a mique feature in the whole group; the metallic colour is distinctly green in all lights, not blue; and in the secondaries below the white marks are distinct stripes and lines, and not broken up as in rochana.

I figure a female from Celebes in my own Collection.

\section{IrAotA NILA Distant.}

Jraota nila Distant, Rhop. Malay. p. 462. n. 2, pl. xliv. fig. 24, $q$ (1886); Druce, Proc. Zool. Soc. Lond. 1895, p. 588. 1, xxxiii. fig. 1, ơ ; de Nicéville and Martin, J. A. S. B. vol. lxir. pt. 2, p. 463. n. $38+$ (1895).

Ilab. Malacca; Bornco; Sumatra; Perak.

Expanse, of 39-40, o 41-12 mm.

8. Upperside: both wings blackish with a steely-blue lustre in certain lights, with bright deep blue stripes in the cell, the median interspaces, and the submedian area; in the secondaries these stripes are confluent, forming a good-sized patch intersected by the blackish nervures, the two tails short tipped with white; lobe small, but well defined; antenn unusually long and tipped with whitish. Underside: both wings pale ochreous with white spots. Primaries: cell closed by a white spot above and below which are confluent, white marks extending to the costa and lower median nervule, beyond which there is a patch of reddish, edged exteriorly by three white spots, beyoud which are three more smaller white spots in the apical area; below the centre of the red patch are two white spots, followed exteriorly by two larger black spots with indefinite reddish margins; submedian area dark grey, below which the ground-colour becomes whitish. Secondaries with three white spots below each other encircled with black rather near the base, beyond which are four more white spots encircled with black, below the lowest of these and nearer the anal angle is an irregular black mark pmpilled with white extending to the internal nervure; at the apex is a good-sized red jatch, at the outer edge of which are four small white spots encircled with black; a marginal row of five white dots in the nervule interspaces and an isolated black spot 
in the lower submedian interspace somewhat near the outer margin; tails and lobe velvety black, above which are two ill-defined white marks.

q. Upperside: both wings steely lustrous bluish; costa aud outer margins of primaries narrowly brown; costa of sccondaries broadly, onter margin narrowly, brown; two tails, brown tipped with white. Underside exactly like the male.

This is a very beautiful and distinct species. Mr. H. H. Druce has figured, in the 'Proceedings Zool. Soc. Lond.' for the year 159j, a male from Borneo with metallicgreen interspaces; this is a very beautiful local race. Two males now before me from Sumatra have no trace of the green in any light, but are deep bright blue.

This species may be recognized at a glance from any others; it is very much smaller in size.

\section{Amblypodia Horsfield.}

Amblypodia Horsfield, Cat. Lep. Mus. E.I.C. p. 98 (18:9) ; Moore, Lep. Cey. vol. i. p. 113; Distant, Rhop. Malay. p. 275 (1895); de Nicéville, Butt. Ind. vol. iii. p. 208 (1890); Staudinger, Exot. Schmett. (in parte), p. 281 (1888); Schatz and Rüber, Exot. Schmett. p. 275 (189\%).

Wings broad. Primaries with base curved, apex pointed and acute, costa archerl more strongly at base; posterior margin almost straight or very slightly convex in the male, in the female slightly excavated just below the apex, then decidedly convex; inner margin produced, slightly excavated in the centre. Costal nervure of moderate length, ending just beyond the apex of the cell ; first and second subcostal nervules with their bases close together; third subcostal nervule rising nearer to the base of the wing than to the origin of the upper discoidal; in the female this ends at the apex of the wing, but in the male only a fourth subcostal is present, which is very long, terminating at the apex of the wing, its origin being wuch nearer the origin of the third subcostal than the apex of the wing; the end of the subcostal nervure terminates in the posterior margin just below the apex; the upper discoidal nervure rises from the subcostal long before the apex of the cell, whilst the lower discoidal rises from the upper, well beyond its origin, the base of which is deflexed; lower discocellular nervule upright, slightly concave, twice as long as the middle discocellular; seconel median nervure rising some way before the lower end of the cell; submedian nervire straight at the base, then slightly deflexed towards the apex. Secondaries very considerably more ample in the female than in the male; costa and posterior margin strongly curved, the latter excavated before the submedian nervure, which is produced into it short stout tail; a moderate-sized anal lobe, above which the internal or abdominal margin is somewhat excavated, but is afterwards convex. Costal nervure strongly arched, long, ending at the apex of the wing; first subcostal nervule rising some way before the apex of the cell; upper discocellular nervule shorter than the lower, straight and outwardly oblique; lower liscocellular slightly concave, the secona median nervule rises close to the lower end of the cell, submedian nervure almost straignu: internal nervure 
short, strongly recurred. Antenne short, about one-third the length of the costa. Eyes smooth. Palpi porrect, longish ; thorax stont; body robust; legs short and thick. The arrangement of the discoidal nervules is quite remarkable, and I believe is peculiar to ihis genus and to Ireota Moore-at least, I do not know of any other "Old World" Lycrenidæ which have it. Horsfield figures the larvæ of the usual Lycænid shape with small head and second segment much larger, segments getting wider up to the seventh, then decreasing; the constrictions between the segments are fairly well marked, the sides of the body being slightly bristled. Pupa attenuated in a very unnsual mamer, with the head round, thorax humped, abdominal segments slender, and tail slarply pointed.

Mr. Doherty in describing the egg of A. naratl Horsfield says it is "large, coarse, and orexlaid with white, roughly tubercular, and indented with spaces obscurely hexagonal. It greatly resembles that of most of the "Thecline." "

The tegumen and lateral supports of the prehensores are more fully developed in this genus, whilst the clasps though smaller are vory unusual in shape. Penis small.

Amblypodia namad Horsfield. (Plate IY. figs. 3 \& 3 a.)

Amblypodia narada Horsfield, Cat. Lep. Mus. E.I.C. p. 98. n. 30.

Thecla narada, Horsfield, op, cit. pl. i. fig. 8 ơ , pl. jw. figs. 4 larva, 4 a pupa (1829) ; Horsfield and Noorc, Cat. Lep. Mus. E.1.C. vol. i. p. 39. n. 51, pl. i. figs. 4 larva, $4 a$ pupa (185z) ; Distant, Rhop. Malay. p. 2\% 6. 21. 1, pl. xxi. fig. 23, o (1885); de Nicérille, Butt. Ind. vol. iii. p. 210 (1890).

Amblypodia taoona Moore, Proc. Zool. Soc. Lond. 1878, p. 835 ; de Nicéville, Butt. Ind. vol. iii. p. 211 .

Amblypodia narada Druce, Proc. Zool. Soc. Lond. 1895, p. 58̃ ; de Nicéville and Martin, J. A. S. B. rol. lxiv. pt. 2, p. 463 (1895).

Hab. Mergui; Penang; Malacca, Java, Andamans, Mindanao, Palawan, Mindoro; Borneo; Nias.

Expanse, ơ 51-56, ㅇ 50-58 mm.

§. Upperside: both wings bright purplish blue (I cannot call any male Amblypodia that I have seen true ultramarine-blue, as all had a tinge of purple). Primaries with a moderately broad blackish apex, decreasing in width along the posterior margin; costa rather narrowly black, but variable. Secondaries with costa and apex very broadly (but variably) brown, tapering down narrowly to the upper median nervule, whence to the anal angle the margin is quite narrow; internal margin very broadly brown. Underside: both wings rufous brown; a dark sinuous line passes from the apex of the primaries obliquely through both wings, terminating above the centre of the abdominal margin; from this line to the base the whole of the ground is dark blackish brown with no definite markings therein. In the primaries midway between this line and the posterior margin there is a row of obscure reddish spots darkly edged, those nearest 
the apex being only dark dots; the ground-colour is darker at the apex and anal angle. Secondaries with a similar broad row of confluent spots darlily edged, beyond which edging there is a whitish diffused internal and external scaling; lobe reddish; the lobe is very well developed and adjoins a short stout tail ; marginal area dark.

ㅇ. Upperside: both wings brown, primaries with a good-sized pale azure patch, secondaries with the azure patch very much reduced in size. Underside: both wings ochreous grey, with the oblique stripe passing through both wings, the ground-colour being rather darker up to the base; the other markings us in the male, but approaching evanescence.

This species is most variable, individuals from every island apparently presenting minor differences which it would be absurd to name. A form found in Nias has the female of the same blue colour as the male, an almost unicolorous dark underside with the obliqne stripe as usual, but the lobe has a large velvety-black spot with two or three black marginal spots beyond, all the spots being broadly encircled with glaucous: this form I also have before me from Borneo, but the nnderside is paler. A form found in several of the Philippine Islands has the male with a pale violet patch on the upperside, while the female is not quite so blue as in the type-species, but the underside is strongly tinged with olive-green or olive-brown and is also alnust unicolorous. Specimens of this torm occasionally present a trace of the black spots at the anal augle.

I have no doubt at all that $A$. troom Moore is merely a bright specimen of this species, the blue colour of which varies a good deal. The wilth of the black border not only varies a good deal in the female but in the males also. The clasps of the prehensores are rery peculiar, being small for the size of the insect, but the extremities are strongly serrate and produced upwards into a long straight extension and attached to the laterals by a fine corering of thin chitine; the penis is short and stout.

\section{Amblypodia andersonil Moore.}

Amblypodia andersonii Moore, Journ. A. S. B. vol liii. pt.2, p. 43 (1881) ; ill. Jonrn. Lim. Soc. Lom?., Zool. vol. xxi. 1. 4t, pl. iv. fig. t, o (1886); de Nieérille, Butt. Ind. vol. iii. p. 211 (1890).

Hab. Sampu; Sullivan Island, Mergui (January).

Expanse, ơ, 1.75 inches (le Nicéville).

"o smaller than A. taooana Noore. Upperside: both wings of a similar tint of ultramarine-blue, with much narrower marginal border. Underside: both wings much darker coloured, but similarly marked" (Moore, l.c.). The unique type of this species is in the Indian Museum at Calcutta. De Nicéville say's that the blue colvur is rich and beautiful, and is unlike anything else in the genus, except that he has one specimen of the true A. narala Horsfield with which it entirely agrees. The probability is that this therefore is only an aberration of Horsfield's insect. I keep them separate, as I have been unable to see the type.

FOL. XVII.-PART I. No. 3.-August, 1903. 
Amblypodia anita IIewitson.

Amblypodia anita Ilewitson, Cat. Lycenidæe B.MI. p. 14. n. 66, pl. viii. figs. 90, 91, ठ (1362) ; Butler, Proc. Zool. Soc. Lond. 1883, p. 147. n. 8; Elwes, Trans. Ent. Soc. Lond. 1888, p. 403.

Amblypodia narade var. erichsonii Wood-Mason and de Nicéville, J. A. S. B. vol. xlix. pt. 2, p. 234.

n. 53 (1880); et vol. 1. pt. 2, p. 250. n. 7t (1881) ; de Nicéville, Butt. Ind. vol. iii. p. 211 (1890).

Amblypodia naradoides Noore, Proc. Zool. Soc. Lond. 1879, p. 141; ct Lep. Cey. vol. i. p. 114, pl. xliii. figs. 1, 1 a, \& (1881); de Nicéville, Butt. Ind. vol. iii. p. 212 (1890).

Amblypodia darana Moore, Proc. Zool. Soc. Lond. 1879, p. 141; et Lep. Cey. vol. i. p. 11t, pl. xliii. fig. 2, ㅇ (1881); de Nicéville, Butt. Ind. vol. iii. p. 212 (1890).

Amblyporlia arracana (irose-Smith, Ann. \& Mag. Nat. Hist. ser. 5, vol. xx. p. 268 (1887); de Nicéville, Butt. Ind. vol. iii. p. 213 (1890).

Amblyportia anita Drnee, Proc. Zool. Soe. Lond. 1895, p. 587.

Hab. Siam, Madras, Sikkim, Sumatra, Ceylon, Arracan Hills; Mangioli, Sula Island. Expanse, \& \& o , $50-57 \mathrm{~mm}$.

§. Upperside: both wings dull violet. Primaries with the posterior margin rather broadly blackish, and the costa less broadly so. Secondaries with costa very broadly and posterior margin narrowly blackish, lobe dull red. Tail stout. Underside : both wings rufous brown, with an oblique transverse black line from the apex of the primaries going right through both wings to the middle of the abdominal margin ; from this line both wings are more or less suffused with dark scales-this, however, is very variable indeed, the wings being occasionally almost uniform in colour. The primaries have a very obscure submarginal spotted row, frequently almost obsolete, and the secondaries, as well as the lobe-spot of the secondaries, are black, and there is also an obscure black marginal spot between the second and lower median nervules.

․ Upperside: both wings blackish brown, with the submedian and discal areas dull slightly lustrous violet; in the secondaries this colour is confined to the discal and median areas. I have before me another form of this sex in which the patches on the wings are brightish purplish blue. Underside of both just like male, but with the transverse lines more marked and a slight grey scaling at the anal angle.

I am quite umble to differentiate Mr. Mioore's species and have most reluctantly becu compelled to sink his names, as I really cannot find any true points of distinction. Winen the males are quite indistinguishable I do not consider it wise to make a species on account of the female being of a different form to that usually found: this surely points to nothing else than a dimorphic female, the original one probably being brown, whilst the purplish one is a more recent development.

The colour of ithis species being so constant, it appears to be advisable to retain the name as distinct from nurull, it being an easily recognisable form. 
Amblipodia axietta Standinger.

Amblypodia annetta Standinger, Exot. Sehmett. p. 281, Taf. 96, ते (1889).

Amblypodia annetta var. anna Staudinger, Exot. Schmett. p. 282 (1889).

IIab. Batchian; Waigeoe; Saparua; Amboina.

Expanse, o 45-49, ㅇ $53-55 \mathrm{~mm}$.

§. Upperside: both wings very dark brown, primaries with a discal and submedian patch of submetallic purplish blue; secondaries with the blue confined almost to the discal and medim areas. The colour of this patch is given to vary somewhat, as I have a specimen in which it is metallic deep azure and another in which it is metallic blue of lavender tinge. Underside: both wings miformly rather dark brown, occasionally with a puple tinge; primaries withont any mark at all : secondaries with a submarginal lumulated whitish intermpted stripe, preceded internally by a most obscure dark line; there is also a marginal pale spotted row most obscure at the apex, but quite distinct at and near the anal angle; lobe-spot blackish. I have two specinens from Waigeoe, in both of which there is a distinct trace of the transverse line extending through both wings; this is eutirely wanting in the type specimens from Batchian.

․ Upperside: both wings dark brown, with a much more limited patch (even than the male) of very pale greyish lustrons blue. Underside: both wings pale purplish greyish brown, with a dark oblique stripe through both wings; the posterior margin of primaries broadly brown (not grey or purplish); secondaries with a submarginal tapering spotted row palely edged on both sides, lobe-spot blackish. This description is taken from Waigeoe specimens, as I do not possess a male from Batchian.

The var. anm Staudinger is really not worthy of a name, the only difference being that the blue has a slightly lavender tinge, and this, as we have seen, is variable, as also is the pattern of the underside, or more accurately, I might say, absence of pattern; the female on the underside is precisely the same as the type female, but the blue of the upperside has a slight greenish tinge, otherwise there is no difference.

The species may be recognised from the others by the very small expanse of blue in the males and by the different shape of the wings.

\section{Amblypodia Faisina Ribbe.}

Amblypodia faisina Ribbe, Iris, vol. xii. p. 252, Taf. iv. fig. 16, $q$ (1899).

IIrb. Faisi Island (Bismarck Archipelago).

'This species is very near $A$. annettu Stgr., having been described from a unique female which is the exact colour above of a female of Staudinger's species; but Ribbe's insect is smaller and can also be recognised by the broad pale band on the underside of both wings. 
Avblypoda hasana Crowley.

Amblypodia hainana, Cromley, Proc. Zool. Soc. Lond. 1900, p. 508.

Hab. Hainan.

Expanse $56 \mathrm{~mm}$.

I have not been able to see this species, but it should be recognised without difficulty by its large size, for it is abont 10 millimetres larger than any specimen of the genus that I have seen.

\section{Manathala Moore.}

Mahathala Moorc, Proc. Zool. Soc. Lond. 18\%8, p. 702 ; de Nicéville, Butt. India, vol. iii. p. 282 (1890).

Apporasa Moore, J. A. S. B. vol. liii. pt. 2, p. 39 (1881) ; de Nicéville, Butt. Ind. vol. iii. p. 224 (1890).

Wings broad, short. In the primaries the costal nervure is less than half the length of the costa, terminating well in front of the apex of the discoidal cell; the first and second subcostal and the upper discoidal nervules all have their bases about equidistant; the third subcostal nervule is short, rising nearer the apex of the wing than of the cell; the middle discocellular nervule is rery short, straight, and outwardly oblique; the lower discocellular is nearly four times as long as the middle, concave, and nearly straight. Second nedian nervule given off some little distance before the lower apex of the cell; first median bent downwards near the base. In the secondaries the costal nerrure is strongly sinuate and bent upwards at the end; the first subcostal nervule arises some way before the end of the cell, and is strongly and somewhat evenly arched. The upper discocellular nermle is straight and very oblique inwardly, whilst the lower is likewise equally oblique inwardly, thus forming a $<$ shape. The second median nervule is given off almost at the juncture of the upper median, but just below it-i.e. just in front of the lower end of the cell. The submedian nervure is nearly straight; the internal nerrure short and sinnous. The abdominal margin is decidedly excised, and thus forms a distinct anal lobe. The antenuæ are very short, about a third the length of the costa. De Nicéville (l.c.) says:-_. Although Apporasa atkinsoni possesses a tail similar to Maliathala ameria Hewitson, and the costa of the hind wing is also somewhat similar, yet it is, I believe, nearer to Thaduka multicaudata Moore than to that species. It has the costa of the fore wing arched as in T. multicaudata (considerably more so than in M. ameria)." Joherty (J. A. S. 13. vol. Wviii. pt. 2, 1. 423) says that "the genus Apporasa differs from Mahathala in the less acuminate apex of" the hind wing, in the egg (which is covered with triangles and tubercles instead of quadrangles and spines, a difference which in this group is of small importance), and in the more undulate margin of the hind wing" ; and he continues:- " But atkinsoni when sitting on a trce-trunk las a marvellous resemblance to a patch of lichen, and 
the irregular ontline adds to the effect. Mimicry of this sort is a sign of great flexibility of structure, and such genera must be jurlged by severer canons than others, so perhaps Apporasa had better be sunk in Mrahathala."

I entirely agree with Mr. Doherty in this; the neuration is the same, the arch of the costa of the primaries is rather stronger than in M. ameria, but decidedly less strong than in $T$. multicaudata; the costa of the sccondaries is precisely the same as in Mahathala, and therefore I do not see what use there is in separating the two generain fact, I do not see what characters there are to enable us to separate them. The prehensores are highly developed; the tegumen is very ample, with strong straight hooks, with a considerable muscular attachment ; the clasps are also unusually ample and peculiar. The penis is short and stout. I have described and figured them under the species 11 . ameria IIew.

\section{M.hilatilala atKixsoni (Hewitson).}

Amblypodia atkinsoni Hewitson, Ill. Diurn. Lep., Lỵc. p. 14g. n. 99, pl. iii ל. figs. 4s, 49 (IS69). Apporasa atkinsoni Moore, J.A.S. B. vol. liii. pt. 2, p. 38 (188t); de Nicéville, Butt. Ind. vol. iii. p. 224. n. $781(1890)$.

Wahathala (Atyporasa) athinsoni Doherty, J. A. S. B. vol. 1viii. pt. 2, p. 423 (1889).

Mah. Moulmein; Myitta (Tenasserim Valley), Tilin Maw, and Katha District, x. Burma (Coll. de Nicéville).

Expanse $4.2-45 \mathrm{~mm}$.

o. Uppersicle: primaries very dark blackish brown, tinged with purple; costa lightly spotted, with the discoidal and submedian areas pale lustrous violet-blue (I cannot possibly call it purple); secondaries dark brown, with a similar violet-blue patch as the primaries. Underside: primaries dark brown, posterior margin densely irrorated with grey; costa irrorated and speckled with a similar colour; a whitish dash across the centre of the cell, which is closed by two broad, short, whitish dashes outlining a sort of spot, beyond which is a dark spot laterally edged with whitish; below this several indefinite whitish spots, and the submedian area is also whitish. Secondaries paler brown, mottled and densely irrorated all over with reddish grey or grey tinget with lilac; the cell is closed by a dark mark, and there are one or two spots at the base; a very few metallic bronzy-green scales are scattered here and there over the wiug indefinitely. All the markings are most indefinite on both wings, and the few bromy scales would render the mimicry of lichen (to which Mr. Duherty likens the under:ide) about perfect.

q. Fxactly like the male, except that the blue of the under surface is paler, bluer. brighter, and more extensive.

This is apparently a very rare insect; it has been described for more than thirty years, and there are but few collections in which spccimens appear. It is a beautiful and very intercsting species, and is readily separable from any others of the genus by the 
paler blue and broad margins of the male, as also by the curious colour of the under surface.

Mamathala ameria (Hewitson). (Plate IV. figs. 4, 4 a.)

Amblypodia ameria Hewitson, Cat. Lycrenidæ B.M. p. 14. n. 61, pl. viii. figs. 85, 86, \& (1862).

Mahathala ameria Noore, Proc. Zool. Soc. Lond. 18;8, p. 703; Rothney, Eut. Month. Mag. vol. xix. p. 35 (1882).

Narathria ameria Distant, Rhop. Malay. p. 268. n. 13, pl. xxi. fig. 30, \& (1855).

Mahathala ameria de Niecille, Butt. lnd. vol. iii. p. 283. 11. 818, pl. xxvii. fig. 200, o (1890).

Arhopala (Mahathala) ameria de Nicéville and Martin, J. A. S. B. vol. lxiv. pt. 2, p. 470 (1895).

Ilab. Northem India; Siam; Hainan; China; Barrackpur; Mergui ; Perak; Beerbhum District; Calcutta; Goalpora; Sibsagar; Chittagong Hill Tracts ; Sumatra (Prnul Staudinger); Java.

Expanse, of \& ㅇ, 37-40 mm.

o. Upperside: both wings dull purple; primaries with costa rather narrowly, and posterior margin less narrowly, black; secondaries with apex and costa broadly, and posterior margin less broadly, blackish. 'Tail rather long, broad, and spatulate, scalloped on each side so as to form a short tooth-like projection. Underside: primaries coffee-brown, with pale submedian area; spots searcely darker than ground, laterally edged with greyish white, one in the centre of the eell and one more listinet closing it; below these are two divided by the lower median nervule, above them are often (not always) one or two obscure spots; transverse band broken outwardly after the first and after the second spot, and inwardly after the fourth spot, terminating on the lower median nerrule beyond this; costa and apex sprinkled with grey irrorations; marginal row lunular. Secondaries dark brown, with all the ground between the fascie closely irrorated with greyish; the basal area is very irregularly spotted and blotehed with reddish brown; a reddish-brown irregular fascia from apex to near the base of the abdominal margin, beyond which is another broad irregular faseia from the upper discoidal nervule to the middle of the abdominal margin; marginal row obseure but dark; lobe well formed.

o. Preeisely like the male in every particular, except that the purple area of the upperside is much more restricted.

The female of this species is subject to considerable variation both as to the colour of the blue and as to its extent. I have specimens before me with the purple occupying an area only just beyond the outer limit of the cell, and others which are bright rich blue, with only a broad dark posterior margin and broader apex.

I believe that the male also varies in coluur, for Mr. de Nicéville says the male is not purple but rich deep blue. The clasping-organs here figured are, however, from a specimen which is quite purple aud very dull in tone, and I may say that I have not secu a really blue male. These organs are strongly specialised in this grenus. The 
tegumen consists of a very ample and substantial hood, to the lower part of which are affixed, by a strong muscular attachment, the hooks, which are very robust and straightish, with a slight defleetion at their tips. The clasps are unusually fully developed, and are excised in the middle so as to form the extremities into two strong points. The penis is short, with the hinder two-thirds very large.

Maimatimali himavi, n. sp. (Plate I. fig. 1.)

Hab. Isle of IIainan.

Expanse $48 \mathrm{~mm}$.

‥ Upperside: both wings very dark purplish brown; primaries with a good-sized patch of violet-blue over the discal submedian and two-fitth of the median areas; secondaries with the violet-blue only a little beyond the diseal cell. Underside: primaries coffee-brown (more or less dark), with three rery short and fine white dashes in the cell; cell elosed by a spot laterally edged very finely with whitish, below which is a longish spot edgred above with white; basal area dark up to just beyond the cell, whence the submelian area is quite pale; transverse band of moderately cqual width, strongly curved from the eosta to the upper disenidal nervule, from where it deseends almost straight to the lower median nervule, below which is an irrogular spot shifted inwards; margin rather broadly dark purplish grey. Secondaries: hasal area to well beyond the cell very dark reddish brown, whence to the margin it is of an indeseribable reddish grey of a lustrous texture, having almost exactly the same appearance as in an inseet that is greasy, the separation between the two areas being quite sharply defined; in the basal area there are traees of a spot across the eell, of one below it, and of a larger one elosing the cell, but they are most obscure; in the lustrous outer area the dark thriee-broken transverse panel is quite distinct from the upper diseal to the internal nervure, and is of moderately equal width; marginal area broadly dark.

From $M$. ameria Hewitson this speeies may be distinguished by its mueh larger size and by the blue of the seeondaries being so much reduced in its txtent, whilst the generul appearance beneati is quite different, owing to the uniformity of general tone, though the pattern is very similar; it is, however, much darker, with the whole of the base dark chestnut, and there is a distinct satiny gloss over the whole of thr secondaries.

I have two females from the Isle of IIainan.

M.imatiala gone Druee.

Mahathala gone Druce, Proc. Zool. Soc. Lond. 1895, 1. 59:3.

Hab. Mongolia.

Expanse $47 \mathrm{~mm}$. 
This species is described from a unique type, and is certainly somewhat different from ameria Hew. It would be very satisfactory if we were able to get other specimens from the same district.

Thaduka Moore.

Thaduka Moore, Proc. Zool. Soc. Lond. 1878, p. 836 ; de Nicéville, Butt. Ind. vol. iii. p. 225 (1890).

The neuration is almost the same as in Malathala, but in the primaries the third subcostal nervule is longer; whilst in the sccondaries the costal nervure is bent downwards, not upwards, the subcostal nervule is not nearly so strongly arched, and the internal nervure is decidedly longer than in that genus. 'The two discocellukiar nervules of the secondaries are each inclined outwards, being thus of exactly the reverse position to that in Mahathala, and the lower discocellular nervule is very decidedly longer than the upper.

The costa of the primaries is mose strongly arched than in Mahathala. Palpi slender. Antenne short. Body stont.

This genus may be known from all others by its species having three tails, two of which are somewhat spatulate. Some species of Iircotu have three tails, but they are long and by no means broad. The genitalia approach closely to the pattern of the genus Arhopala, with the fully-developed tegumen and the small clasps.

Thaduka multicaudata Moore. (Plate IV. figs. 5 \& 5 \%.)

Tharluka multicaudata Moore, Proc. Zool. Soc. Lond. 1878, p. 836, pl. lii. fig. 7 , o ; de Nicéville, Butt. Ind. vol. iii. p. 225. n. 785 , pl. xxvii. fig. 196, $f$ (1890).

Ilab. Upper Tenasserim; Nilgiris (January, Augnst, and September).

Expanse, of 38-44, 우 44-48 $\mathrm{mm}$.

8. Upperside: both wings purplish black, with the basal, discoidal, and submedian areas very pale silvery blue; abdomen and fold greyisin. Underside: both wings dark vinous brown. Primaries with the posterior half and the submedian space hoary; the central cell-spot is indistinctly outlined ly pale bluish, and the spot closing the cell is grey with superimposed bluish scales; the dark catenulated transverse band is distinct and composed of six spots, the upper three oblique outwardly, the sccond and third being dislocated, the fourth, fifth, and sixth dropping almost perpendicularly from the third, while all are palely edged; submarginal row of <-shaped shading distinct. Secondaries with the three dark, irregular, ill-detined, maculate, transverse bands palely edged generally; these markings are sometimes very indistinct indeed; anal area with a slight suffusion of bronzy-green or bluish scales, which are sometimes scattered sparingly over other parts of the wing.

․ Upperside: like the male, but with the blue not quite so pale (not silvery) and blner. Underside like the male, but nut so dark and browner; the markings decidedly more distinct and the metallic-bronzy scaing more abundant. 
I am indebted to the kindness of Sir (i. F. Hampson for being able to determine the sexes of this species; he kindly obtained for me a couple of specimens, which proved to be a male and fomale, whose clasping-organs I mounted. The insect is recounisable at a glance, but I have no doubt that the males have often hitherto been mistaken for females, as the extent of blue is quite the same, and there is very little difference in the colour.

In de Nicerville's eollection there is now a good series of this insert, the specimens of which are labelled with dates; some from the Nilgiris are dated January 1; from Atarem Valley (Tenasserim) February; the majority from the Nilgiris, however, were taken in August and september.

The genitalia are rather small. The tegumen is composed of a full hood, the hooks haring a strong musenlar attachment, straightish as in Mahathala ameria, but with a decided deflexion. 'The clasps are small, with the extremities projected well outwards, which can be seen better in the figure (Pl. IV. fig. 5) than it can be lescribed. The penis is unusually short and moderately robust.

\section{Arhopala Boisduval.}

Arhopala Boisduval, Toy. Astr., Lép. p. 75 (1832).

Narathura Moore, Proc. Zool. Soc. Lond. 1878, p. 835 ; Distant, Rhop. Malay. p. 259 (1855).

Nilasera Moore, Lep. Cey. vol. i. p. $11+$ (1881).

Panchale Woorc, Proc. Zool. Soc. Lond. 185:2, p. 251 ; Distant, op. cit. p. 272.

Satadra Moore, J. A. S. B. vol. liii. pt. ii. p. 38 (Isst).

Acesina Mloorc, tom. eit. p. 41.

Durasana Moore, tom. cit. p. 12.

Flos and Iois Doherty, J. A. S. B. vol. Wrii. pt. ii. pp. 411,412 (1ss9).

Arhopale aud Acesina de Nicéville, Butt. Iud. vol. iii. pp. 226, 280 (1890).

Amblypodia (auctorum).

Wings broad and ample. Primaries: costa variable, nearly straight, slightly areleel or decidedly arched, sometimes somewhat depressed towards the apex; apex acute or subacute; outer margin occasionally straight or sometimes evenly convex, and sometimes concave below the apex, then convex; inner margin generally, not always, slightly hollowed in the centre; costal nervure short but variable, never reaching as far as the eud of the cell ; first and second subcostal and upper discoidal nerviles with their bases nearly equidistant. Third subcostal nerrule rising nearer to the apex of the wing than to the apex of the cell, variable in length, but generally short; middle discrcellular nervale rising some little way beyond the source of the upper discoidal, very short, straight, outwarlly oblique; lower discocellular nervule variable, sometimes twice as long or up to four times as long as the middle discocellular, straight, generally but not always slightly inwardly oblique. Seeond median nervule rising some way from the luwer end of the cell; lowest median nervale bent downwards and curred. Median

rol. xvil.-Pant I. No. 4.-August, 1903. 
nervure angled upwards to the origin of the latter nervule. Submedian nervure some times straight, often waved. Hind wing generally ample, sometimes with no tail, generally with a tail at the end of the first median nervule, which is sometimes little more than a tooth, but varies considerably, and is not unfrequently long; sometimes there is a second very short tooth-like projection at the end of the second median nervule, and occasionally yet a third very short one at the end of the submedian nervure. Anal angle sometimes round or sharply angled or sometimes distinctly lobed. Inner margin variable, straight, enarginate, or rounded. Costa evenly arched, sometimes Hattened, sometimes wared. Costal nervure generally well arched, but sometimes considerably straighter. First subcostal nervule well arched, rising generally well before the apex of the cell; upper discocellular nervule shorter than the lower, rather concave, and somewhat oblique ontwardly; lower discocellular erect, or somewhat oblique inwardly, or occasionally straight, rarely concave. Second median nervule rising just before the lower end of the cell; submedian nervure wared; internal nervure recurved. Autemm short, generally less than half the length of the costa, with a slight graduated chub. Palpi rather long, porrect. Eyes smooth. Body generally decidedly robust. The larva is said to be onisciform, flattened in the anal region, and bristly laterally. Pupa of the usual Lycæuid shape.

Boisdural created the genus Arhopala and placed in it two new species, one from Now Guinea and the other from the Aru Islands, which he named respretively A. phryxus and $A$. meander. Unfortmately he did not diagnose the genus, aud until within the last decade the brothers Felder are the only authors who have used it. In Isss Dr. Staulinger drew attention to it in his 'Exotische Schmetterlinge,' and since then it has been generally accepted in a more or less restricted manner; de Niccille, however, was the first who used it in its wide and, as I believe, correct sense. Distant, in lis 'Rhopalocera Malayana,' does not use it at all. Mr. Moore, however, has split the genus up considerably, creating no less than seven genera ont of it, of which I can only retain one, viz. Mahathala. Acesina, which de Nicéville retnins with donbt, has sumewhat distinct markings below, but they coincide precisely with the general Aihopala pattern, and there is no structural difference whatever. As regards the structural characters relied on by Mr. Moore in the genera that lie suggested, there is not one that is constant; the whole are extremely variable, even in the species which are most nearly allied, and no good can be gained by subdividing a large and well-marked genus like this, merely for the sake of making it less unwieldy, when no definite and good characters can be given. I feel, therefore, with all teference to so old and experienced in observer, that I cannot adopt his ideas on this point. I have examined a considerable number of the prebensores of the males, but do not find that they aid much in this respect, and it seems very doubtful if the eggs will be sufficiently well known in our scneration to be of any use in the matter. The headquarters of the genus are Inclia 
and the Mitlay region; species occur, howerer, in (hina and Japan, also in Australin and some of the small islants of the Piteitic, such as New Britain and the Solomon Group. In colour the sprecies are nearly all blue or purple, though a few are of a brilliant histrous metallic green, whilst one or two are almost brown. In the ease of the green species, however, the females are all blue or purple, and were it not for the pattem below coinciding precisely (as it does in every ease) they would be, and occasionally have been, looked upon as distinet species. Distant remarks mon the shate of the blue varying considerably in the same species, whilst de Nicéville disagrees with the assertion. I think that now the latter author would probably have qualified this had he been alive. I have found decided differences in the colour of the same species, but how that lifference has arisen I an not prepared to say. I think it is quite possible that it is a chemical change, for the specimens look quite fresh, so that it is not unlikely that it may have been thus produced. The colours of the whole of the group are aniline-that is to say, they can only be compared to aniline colours,-and I believe the majority of them conld not be made up from the colours of the spectrum; they may theretire be more liable to change than otherwise.

I have not found the difficulty in recognising IIewitson's speeies that some have, aml I believe I have been successful in nearly every case; all that I found necessary was time and care.

De Nicéville and Martin say (J.A.S. B. vol. lxiv. pt. ii. p. 470):-_"This genus is one of the most largely represented in sumatra, which may perhaps be its headquarters, though the Malay Peninsula may possibly possess quite as many species. All are found in forests, but, nevertheless, their more or less metallic-blue, purple, and green colours are not at all conspicuons, and they do little to enliven the sombre depths of the forest, as the restless specics of Lampides do. Arhopalce never come to small streams or damp spots on roads to suck up the moisture, or to flower's they hardly ever fly unless disturbed, and as they always settle with folded wings, of which the undersides present only dull brown, grey, or dull purple colour, little is seen of them. They rest on leaves of shrubs of morlerate height, and never fly for any length of time to a distance, feeling themselves much more secure when at rest. There is therefore only one way to see and capture them, and that is to walk through the underwoor and disturb them by beating the bushes and low trees, and thus to eause them to Hy." And, again, de Nicévilie says (13utt. Ind. l. c.): "Many speeies seem to be common where they occur, others, again, appear to be very rare. Owing to their skulking habits, there is a good deal of difficulty in collecting them."

'The genitalia follow one pattern very closely, having the tegumen composed of an ample hood with strong muscular hooks straightish, $i$. e. not elbowed, the clasps decidedly small, and the penis of a medium size. 
Arhop.la inercules (Hewitson). (Plate IV. figs. $6 \& 6$ a.)

Amblypodia hercules Hewitson, Cat. Lycrenidre B.M. p. 3. n. 14, pl. viii. figs. 92 \& 93, o (1 862). Arhopala tyrannus Felder, Reise Novara, Lep. vol. ii. p. 225. 1. 247, tab. xxix. firs. 1 \& 2 , $\delta$ (1865).

Arhopala hercules Her., Staudinger, Ex. Selmett. p. 280, Taf. xevi., o (1888).

Arhopala tyrannus Felder, Standinger, Ex. Schmett. p. 280.

Arhopale hercules var. herculina Staudinger, Ex. Schmett. p. 280.

Arhopula leo Druec, Amn. \& Mag. Nat. Hist. ser. 6, vol. xiii. p. 251 (1894).

Hab. Makassar; Java; (?) Hulmaheira; Waigeoe; N. Guinea, Inuboldt Bay ; Gilolo and Ati Ati (N. Guinea).

Expanse, of \& $+62-75 \mathrm{~mm}$.

This species is the largest and one of the handsomest of the genus, its wing-expanse frequently reaching $75 \mathrm{~mm}$. It has beeu recorded from many of the Malay Islands, and extends as far as New Guinea, this being apparently its eastern limit. In the figure of the genitalia, I would draw attention to the straight sword-like hook and the peculiar upward extension of the clasp.

Var. LEO Druce,

Differs from hercules on the under surface in that the colour is hoary and tinged with very pale green, the transverse fascia on the primaries is more broken, and the same fascia on the secondiries is quite broken up beyond the fracture at the lower discal vein, and does not continuously extend to the internal vein.

This was described by Druce from Humboldt Bay, New Gninea, whence I have several specimens; it forms an excellent transition to Standinger's form "herculina" from Waigeoe.

Var. Herclina Stgr. (Plate I. fig. 9.)

C. Upper surface blue, brighter with less purple in it than hercules. Under surface with a very slight trace of green on the basal area of both wings, which is often entirely absent, the whole surface being pinkish grey; the transverse band in the primaries is more or less broken into a continuous chain of spots, not an unbroken lrand as in hercules, and this also applies to the same band in the secondaries, which furthermore is sometimes fractured between the subcostal and the upper discocellular veins, and at the upper and the lower median veins. At the anal angle there is 110 metallic scaling as is usual in hercules.

․ Brown all orer, a shacle lighter beyond the discal area of both wings. I have another form brown, with a whitish patch beyond the discoidal cell in the prinaries, over which a number of fine pale lavender-coloured scales are very distinctly spreat. A third form before me is Staudinger's blue female, which, as he says in his original description, is almost as blue as the male, the apical and costal areas being broadly brown, the expanse of blue equalling that of leo. 
This is a very interesting form indeed, for it is an insect that I should say was in ? transitional state, either allapting itself to new conditions, or, finding itsclf hard pushe $\mathrm{l}$ for existence, seizing on certain atwantages of colour ; for far from being of the very constant form of the parent species, individuals of this variety differ inter se on the underside in the pattern very considerably. They are in size rather smaller than hercules. Staudinger described his rariety from Waigeoe, but we have since receiver examples from Halmaheira, from which island I have one without any transverse band on the primaries.

Mr. Druce regards the entirely brown females as belonging, possibly, to a distinct species; I have some now before me, but they are without doubt of the same species. It is no more than a case of reversion.

Var. TrRaxyus Felder.

o. Just like hereules Hew., except that the underside is brown with no trace whatever of green, and the pattern is merely of a darker shade.

ㅇ. U pper surface entirely dark brown. Inder surface like the male. I have one specimen from Ati Ati, on the west coast of New Gninea, which forms a transition from herculina to tyrannus.

This species is apparently confined to the Malay Archipelago, where it is evidently dominant, setting up local forms in various islands. I have examined a very large number of specimens and find small divergencies arising in many cases, and have no doubt that the varieties described are local forms of Hewitson's species.

Ariopala ate (Hewitson).

Amblypodia ate Hewitson, Ill. Diurn. Lep., Lب̣c. p. 8. n. 32, pl. i. fig. 4 (1869).

Ilab. Amboina.

Expanse $47-49 \mathrm{~mm}$.

c. Upperside: both wings purplish blue, very slightly lustrous in certain lights, shaded with a brownish lustre. l'rimaries with costa and posterior margin narrowly brown, but slightly increasing at the anal angle. Lobe fairly dereloped; tail brown, white-tipped, and rather long, a tooth-like projection at the end of the second median nervure. Underside brown, slightly lustrous, with darker spots and fascia palely margined. Primaries with a small dot in the cell beyond the middle; cell closed by a rather small elongated spot, below the coll is an obscure darker spot; transverse band almost continuous, slightly oblique outwardly, rather narrow and tapering rapidly to the lower median nerrule where it ends; submarginal row obscure, submedian area paler. Secondaries rather darker than primaries, with three minute basal spots, the upper one the darkest, followed by three more very small spots below each other; cell closed by a very narrow, elongated, curved spot; transverse band continuons, almost straight, moderately broad to the spot between the lower and submedian nervures, 
which is shifted well inwards, and is almost confluent with the long spot extending up to the internal nervure; submarginal band broad and distinct to the second median nervule. Lobe-spot black, and a black spot between each of the two following nervurespaces, each broadly edged above with brilliant, very pale, greenish-blue, metallic scales, over which is greyish irroration.

Hewitson says: "Probably only variety of $A$. adatha" (1. c.).

The species has no close affinity with adatha Hew. I have examined his type and have a specimen also from the same locality (ex Mus. Dr. Standinger); it is really more like a miniature hercules, and will be best placed next to that insect. It has apparently never been noticed by collectors since it was described, and the only specimens known to me are in Hewitson's collection and one in Staudinger's collection, so that it seems to be confined to the little island of Amboina.

Ariopala philaxder Felder. (Plate 1V. figs. 7 \& 7 a.)

Arhopala philander Felder, Reise Novara, Lep. vol. ii. p. 2:26, tab. xxix. fig. 9, ठ .

Arhopala periander Grose-Smith, Novit. Zool. vol. i. p. 58.2 (1891); id. Rhop. Exot., Lỵc. vol. iii. (1898).

Hab. Halmaheira, Batchian.

Expanse, ơ $47-50$, $+52 \mathrm{~mm}$.

o. Upperside: primaries and secondaries deep blue, slightly lustrous, with very narrow black costal and posterior margins to the primaries; in the secondaries the costal border is broad, the posterior margin narrow, the abdominal fold entirely dark brown up to the submedian nerve; the lobe is very slightly developed and is black. Underside: both wings uniform brown, internal margin of primaries paler. I)iscocellular spots three, dark brown, encircled with grey, increasing in size, the last one closing the cell, below which and the central spot is another spot palely encircled. The transverse band from the costa to the lower median nervule, inereasing in width to just below the second median nervule, is bordered on each side with grey; touching this bani below the third median nervnle is another spot placed nearer the base; subuarginal band distinct but ill-defined, with a narrow posterior and a broad interior lighter edge. Secondaries with four small basal darker spots palely encircled below one another, the second placel a little inwards, and the fourtl on the outside of the internal nervure, ontside these are three larger ones correspouding in position to the three upper basal spots. The cell is closed by a long quadrate spot, below which is another small spot filling up the interior end space between the second and lower median nervule. Band contiuuous, but somewhat fractured at the upper discoidal nervure and also at the lower median, whence it is continued upwards to the internal norvure following the course of the margin. There is an indefinite trace of a submarginal darker shading, between which and the median band is a pale grey 
shading; above the anal angle the lobe-spot is black, edged above with a green iridescence, which is extended up to the second median nervule, and underneath which black spots show through the green scaling. The margin has a very fine grey border at the anal area. Tail brown, tipped with white.

\%. Upperside: blue rather brighter than in male, extended almost all over both wings; primaries have the costa blackish beyond the costal nervure; the apical area is broadly black, narrowing to quite a moderate border both towards the costal wein and the anal angle; in the secondaries the blackish costal margin is broad, the posterior margin is rather narrow, increasing a little at the anal angle; the whole of the abdominal fold up to the submedian nervure is brown.

This is another species that appears to have been unobserved and unecorded since its description by the Bros. Felder. When examining the Felder Collection in the Tring Museum I found the unique type, and recognised it as close to some specimens in Staudinger's and my own collections, and I find they are identical. I have before me one female (coll. Staudinger) from IIalmaheira, which I make the type female, as it corresponds with Felder's type; I have also five males and one temale from Batchian.

From mernuler Boisd. it may be rêcognized by the uniform brown colour of the under surface, and by the transverse band of the primaries being narrower at the costa than at its termination.

I cannot really separate periander Grose-Smith from this species.

The genitalia have a most ample tegumen; as usual in this genus, the clasps are distinct, somewhat fan-shaped, but more extended on one side. The penis has a somewhat boat-shaped orifice, as will be seen in figure $\tau a$.

\section{Arhopala hy lavder Grose-Smith.}

Arhopala hylander Grose-Smith, Novit. Zool. vol. i. p. 582 (1894); id. Rhop. Exot., Lyc. no. vii. pl. xv, figs. $6, \tau, 8$ (1898).

Ilab. Biak.

Expanse 65-70 $\mathrm{mm}$.

This species is a close ally of philander Feld., scarcely differing from it, the one distinction being that in Felder's species the transverse band near the posterior margin of the primaries is straight, whereas in the present species it is broken at the upper median nervule.

Arhopala etrisus II. H. Druce.

Arhopala eurisus Druce, Proc. Zool. Soc. Lond. 1891, p. 3r0, pl. xxxii. figs. 11 , 12 q.

IIab. Aola; Guadaleanar Island; Florida Island; (Solomon Islands) New Britain.

Expanse, : 51, o $48-51 \mathrm{~mm}$. 
I have a female before me from New Britain, in which the blue is less silvery, but decper and richer in tone, aud the underside is also rather darker. This species is near Milunder Feld., but is smaller and is paler in colour above; whlst beneath it is more uniform in tone, and the transverse bands are more irregular. The female is also much paler and silvery in its blue.

Var. tindali Rilıbe, Iris, 13d. xii. p. 251 (1899).

This variety appears to be merely a darker form of Druce's species.

Arhopala meander Boisdural. (Plate IV. figs. $S \& S \alpha$.)

Arhopala meander Boisduval, Voy. 'Astrolabe,' Ent. p. 76 (183?).

Amblypodia meender Hewitson, Cat. Lycænidæe B.M. p. 4, pl. ii. figs. 4, 5, \& 6 (1862) : id. Ill.

Dium. Lep., Lỵe. p. 4. n. 6 (1869).

Arropala meander Boisduval, Miskin, Annals Queensland Mus. no. 1, p. 70 (1891).

Arhopala meander Boisd, Betlmme-Baker \& Druce, Proe. Zool. Soe. Lond. 1896, p. 658.

Arhopula adlierbal Grose-Smith, Rhop. Exot. vol. iii. p. 10, pl. xsv. fig. 3 (1902).

Arhopala appicenus Grose-Smitl, Rhop. Exot, vol. iii. p. 11, pl. xxv. fig. 4. (1902).

Ilab. Aru; New Guinea; Waigeoe; Halmaheira; New Britain; New Zealand (Mioko); Queensland and Suth-east Dorreo; Woodlark and Fergusson Islands; Duke of Tork Island.

lixpanse, of \& $+47-j 9 \mathrm{~mm}$.

c. Ulperside: both wings violaceous blue; primaries with narrow black costal margin and rather broader posterior nargin; secondaries with broad costal and narrow posterior margin; abdominal fold brown. Tail black, tipped with white. Underside: loth wings pinkish lilac-brown, all the spots cinuamon-brown, margined with pinkish arey. Primaries: internal urea up to about the second median nervule paler and not finged with pink; three discal spots increasing in size, and the nsual two below the cell; transverse band continuous, inclined outwards as it nears the anal angle; this band gencrally reaches the submedian nervure, but the last two spots are shifted much inwards; an indistinct submarginal shading. Secondaries with four small basal spots below one another, the bottom one shifted inwards beyoud the internal nervure, beyond which are three larger ones corresponding in position to the upper three; cell closed by a long quadrate spot, below which and touching is another small spot closing the end of the space between the second and lower median nervures; transverse chainband nut absulutcly broken, but consisting of two spots above the upper discal nervure, and two spots shifted outwards below it, one between the upper and second median nervure shilted slightly inwards, the next spot is outwards, and that betwcen the submedian nervere and the lower median nervule is mored inwards and forms an acnte angle on its interior edge, thus joining the long spot reaching the internal nervure; submarginal shading darker, with a faint pale outward border; small spot at anal 
angle (there is no lobe) black, surmounted with a green iridescence, which is extended slightly into the marginal area between the submedian nervure and the second median nervule.

‥ Upperside: both wings as in male, but with a broad costal apical and posterior marginal border to the primaries; in the secondaries the costal margin only is broader than in the male. Underside precisely as in male.

This is probably the most variable species of the genus; the blue varies through violaceous to purplish up to lustrous cobalt, and the underside presents some wonderful divergencies. I have before me about 60 specimens, and have examined a considerable number more, and find that the ground-colour underneath runs from the typical pinkish through all shades up to deep rich purplish red and blackish red; then, again, a not uncommon form is rich reddish closely irrorated with bronzy-green scales, giving the insect a very beantiful colour. The markings are also subject to very great exaggeration, the spots being enlarged all over the wing, so that in the hind wing nearly all the spots and bands touch one another. The richest example before me is one from Southeast Borneo, kindly lent me by ITerr Ribbe. The species is evidently common all over the Malay Archipelago. I have specimens from New Guinea, IIalmaheira, Waigeoe, New Britain, Mioko, Aru, and Queensland.

Boisdural's description of this species would suit almost any of the group. It is necessary therefore to take the first figure, which is Hewitson's (B. M. Cat. p. 4, pl. ii. figs. $4,5, \mathbb{*} 6$ ); he knew Boisduval's insect, and the figures 4 and 5 are good, so that the insect can be recognised at once therefrom.

Mr. Grose-Smith has described two species, A. adherbal and A. appianus, both of which must, I fear, be sunk under meander Boisd. As already mentioned, I have had a very large number of specimens from the Malay Islands and elsewhere, showing a most remarkable range of variation, specimens varying from the same locality, some of which quite correspond with Mr. Grose-Smith's figures, and I cannot but regard them as aberrations. The genitalia have subovate clasps, and the penis is rather slender.

Arhopala constaxces de Nicéville.

Arhopala constancece de Nicéville, Journ. A. S. B. vol. lxiii. pt. 2, p. 34. n. 30 (1894).

Hab. South Andaman Isles.

Expanse, 우, $48 \mathrm{~mm}$.

Ir. de Nicérille described this species from a unique example taken at Port Blair by the late Mr. R. Wimberley. It may be merely an aberration of meander or one of its allies.

Arhopala AnYtis Hewitson. (Plate IV. figs. 9 \& 9 a.)

Arhopale amytis Hewitson, Cat. Lycenidx B.M. p. 4. n. 16, pl. ii. figs. $\tau, \&, \& 9$, \& (186?); id

Ill. Diurn. Lep., Lỵc. p. 4. n. 4 (1869).

VOL. XVIL-PART I. No. 5.-August, 1903. 
Amblypodia riblei Röber, Iris, vol. i. p. 70, pl. v. fig. 5, o (I886).

Amblypodia cryonthe Miskin, Proc. Limn, Soc. N.S.W. (2) v. p. 43 (1890).

Arhopala amytis Hew., Miskin, Aunals Queensland Mus. no. I, p. 70 (1891).

Arhopala cryonthe Miskin, l. c.

IIab. Queensland; Aru; Waigeoe; Woodlark Island; Fergusson Island; Tokal Key; and New Guinea.

Expanse, of 47-54, of $48-58 \mathrm{~mm}$.

c. Upperside: both wings brilliant morpho-blue, shading into purplish towards the costal and posterior margins of the primaries and towards the posterior margin of the secondaries. Costa of primaries narrowly black; posterior margin broader, increasing in width at the apex. Costa of secondaries broadly blackish; posterior margin narrow, abdominal fold entirely brownish; tail black, tipped with white; lobe scarcely developed. Underside: both wings reddish brown, with all the spots of a darker hue with pale margins. Primaries: imer marginal area paler brown, apical area washed with very pale pinkish lavender; three diseal spots increasing in size, the upper portions of each side of which are margined with pale silvery bluish, the usual two spots below the discoidal cell ; transverse band continuous, inclined outwards, terminating on the lower median nervule, below which, but unconnected with it, are one or two semi-coalescent spots shifted well inwards; submarginal row of darker spots very indefinite; the upper and apical areas are dusted orer with grey. Secondaries with a broad subeostal streak of pinkish lavender, with the four basal spots followed by the three large ones as usual; cell closed by a large quadrate spot, below which is a small spot filling the terminal space between second and lower median nervules. Transverse band unbroken, axtending round up to the internal nervure; the onter edge of this band is very jagged and irregular. Submarginal shading contimuous, between which and the band is a broad space of grey. Margin rather broadly and very darkly bordered; anal spot small, black, surmounted by slight green iridescence, which extends slightly over the marginal area between it and the second median nervule.

ㅇ. Upperside: both wings brilliant, slightly greenish morpho-blue; primaries, very broad apical and outer marginal areas and a narrow costal margin black. Secondaries with costa and apical margins very broadly blackish; posterior margin not so broad, but increasing in width at the anal angle; abdominal fold brownish. Underside as male.

I have another form of the female which has the blue darker, almost like the male, but a shade paler perhaps.

'The genitalia have the clasps peculiar, with excised extremities; the penis has a globular orifice. 
Tar. Ribber R̈̈̈ber.

o. Upperside rich purplish or vinlet-blue; primaries with very narrow black costal and posterior margins; secontaries with broad blackish costa and rery narrow outer margin; tail moderately long, stout, black, tipped with white; lobe slightly dereloped. Underside exactly as in amytis Hew.

f. Upperside paler than the male and more violet in tone; primaries with very broad costa, and much broader posterior margin and apex; secondaries with very broad margins all round. Underside exactly as in amytis Hew.

This insect is evidently a local form of Hewitson's species amytis, but it differs in the deep tone of the blue of the upperside, and the very narrow margins of the males. I have specimens of it before me from Aru (the types), Tokal Key, one male from Waigeoe, and one male from Ati Ati Onin (New Guinea). Miskin has also recorded two specimens of it from Cape lork under the name cryonthe, but, as Röber described it two years previonsly, Miskin's name falls. Amytis is somewhat variable as to the tone of the blue, and decidedly variable as to the pale subcostal streak on the underside of the secondaries, which is subject to obsolescence. I have several specimens in which it is practically obsoletc, and many where there is only a slight trace of it, and these forms occur irrespective of locality.

Throngh the kinduess of Mr. H. Druce, I have been able to examine some specimens from Furgusson and Woodlark Islands, all of which have no trace of the pale subcostal streak; one female from Fergusson Island is unusually large and robust.

Arhopdla maxe (Hewitson). (Plate 1II. fig. 22, o.)

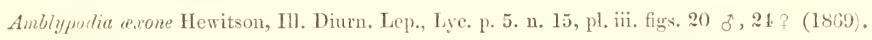

Jab. Waigeoe; New Guinea; Halmaheira; Aru; Kiriwini Island.

Expanse, o* 44-51, ㅇ $43-49 \mathrm{~mm}$.

o. Upperside: both wings brilliant silvery morpho-blue, purplish at the costa and apex of the primaries, which have a very narrow costa, rather broader posterior borter of black ; the secondaries have a broadish black costa, narrow black posterior margin, and dark grey abdominal fold; the tail is long, stont, and white-tipped, and above it at the end of the second median nervule is a tooth-like projection. Underside: both wings very dark; the primaries have three discal spots traced out by silvery-bluish edges, ahmost obsolete as to the internal edge of the third spot, which has a pale onter edging; otherwise the ground is very broadly quite pale, with more or less of a lilac suffusion, the paleness extending throughont the submedian area. Below the second and third discal spots are two other obscure spots divided by the lower median nervile. The transverse band in the midlle of the pale area is continuous, slightly curved, broadish, and generally slightly tapering narrower to the lower methian nervire, where it terminates; it occasionally has a distinct bend or angle. Submarginal row present as usual. Secondaries: the basil three-quarters of the wing very dark indeed and 
markless, followed by a pale broad internal edging to the usual submarginal row, this band of pale edging having a lilac tinge at the anal area; a black spot at the lobe and hetween the second and lower median nervules, between and over which is a seattering (more or less plentiful) of greenish metallic scales.

․ Upperside: both wings blue, slightly paler and less lustrous than in male. Primaries with costa broadly, posterior margin very broadly, and apex yet more broarly black; secondaries with costa and upper part of the posterior margin very broadly black indeed, but the margin of the anal area much more narrowly black.

At first sight this unmistakable species scarcely looks in its right place here; its size and shape, however, bring it at once into this group, and a careful examination of the under-surface pattern soon locates it ; the markings of the primaries are exceedingly close to micale Blanch., whilst in a female in my collection the transverse band of the secondaries is quite traceable, and in other specimens before me isolited spots are discernible, so that $I$ have no hesitation in fixing it here.

Arhopala sophrosyne (Grose-Smith).

Amblypodia sophrosyne Grose-Smith, Eut. Mo. Mag. xxv. p. 300 (1889).

Arhopala sophrosyne Grose-Smith, Druce, Proc. Zool. Soc. Lond. 1891, p. 370, pl. xxxii. fig. 9, ठ .

Hab. Guadalcanar Island (Solomon Group).

Expanse $49-53 \mathrm{~mm}$.

This species is described by Mr. Grose-Smith with tails, but figured by Mr. Druce without tails, his specimen having the tails broken off. It is a tailed species and very distinct.

Ariopala micale Blanchard.

Arhopala micale Blanchard, Boisd., Hombron \& Jacquinot, Voy. Pôle Sud, Lép. pl. iii. figs. 11, 12. Amblypodia micale Boisd. MS., Hewitson, Cat. Lycrenidie B.M. p. 7 (non adatha Hew. pl. iv. ơ , figs. 29, 30, 31) (186:); id. Ill. Diurn. Lep., Lycænidæ, p. 8 (1863). Amblypodia superba Röber, Iris, vol. i. pt. 4, p. 199, Taf. ix. fig. 3 (1887). Aihopala micule Blanch. et superba Röber, Staudinger, Ex. Schmett. p. 280, Taf. 96, ơ (1888).

Hab. (Amboina?); New Gininea; Batchian; Halmaheira; Gilolo.

Expanse, of 52-61, ㅇ $45-59 \mathrm{~mm}$.

o. Upperside : both wings lustrous ultramarine-blue, shading into purplish in certain lights on the costal and posterior margins in primaries; costa in secondaries broadly blackish, posterior margin narrow; abdominal fold entirely fuscous up to submedian nervure; tail tipped with white. Underside: both wings darkish brown, all the markings dark brown, with paler margins; primaries with three discoidal spots increasing in size, partly margined with pale blue, this colour being confined to the imner edge of the large spot closing the cell, the two usual spots just beneath the cell; the transverse band, edged with whitish on the upper part of the inner edge, almost 
touches the third cell-spot aud generally tapers down considerably to the lower median vein, where it ends; on the other side of this vein is another spot liable to obsoletion, shifted well inwards; ontside this band is a pale grey shading, forming the imner edge to the almost obsolete submarginal row of spots. Secondaries with four basal spots, the second and fourth shifted inwards, beyond which are three larger ones; cell closed by a long quadrate spot, below which is a small one occupying the termination of the space between the second and lower median nervule. Transverse band continuons, extending round to the internal nervare; this band has exceelingly uneven and jagged margins, but it is unbroken, though fractured to a certain extent at the lower median nervule; outside this fascia, and following its exact course, is a line of unbroken crescentic pale grey marks followed by a pale brown submarginal area. Anil spot black, sumounted by a bluish or greenish scaling, which extends up to the second median nervule aud is margined by a whitish line; there is also a small black spot at the margin of the bluish scaling between the second and lower median nervule. Tail stout, blackish, tipped with white. There is often a pale subcostal stripe more or less developed.

․ Uppersile: both wings much paler than the male; primaries with costa of medium width, posterior dark margin very broad, apical area broader still ; secondaries with broad margins all round. Underside exactly as the male.

The form usually found in New Guinea, whence I have several specimens, is deep' purplish, almost the colour of $A$. hercules Hew., but not lustrous, with the underside paler and more uniform. I have, however, one typical female.

In this species the underside pattern is somewhat liable to obsoletion, more particularly in the secondaries; this is caused by a darkening of the ground-colour and a slight lightening of the markings. The insect should be easily recognised on account of the brilliancy of the blue, whilst the under-surface pattern is also well marked in tone of colour as well as pattern. Every author that has hitherto mentioned this species has added a little to the confusion of its identification. The original figure is bad beyond comparison, and Blanchurd's description is much too vague to serve for identification. We then come to Hewitson, who first confused it with his own allutha, but afterwards discovered his error (IIl. Diurn. Lep., Lyc. l.c.) and raised both to specific rank quite correctly; unfortunately, however, he did not separate the two species in his cabinet, where they remain up to this moment wixed together. He knew Boisduval's specimens, and there is no difficulty whatever in separating the two species. Staudinger next refers to it $(l . c$.), and says that he regards amytis Hew. as a synonym of this insect; but he is wrong in this, the two species being quite distinct: superbu Röber is, however, synonymons; I have the type of this species before me, and it is like typical micrle, except that the underside of the wings is paler and the whitish is more developed and the paler subcostal stripe of the secondaries strongly marked. This form was described from Batchian, but I have it also from Halmaheira, Gilolo, 
and Ternate, with these characteristics more or less developed, and therefore the name should fall, as it is quite impossible to draw a line between this and typical micale, and all occur indiscriminately in the same districts.

Staudinger's reference of amytis to this species leads me to say that micrle can be at once separated from amytis by the rounder apex, narrow black outer margin, the fuller secondaries, the intense blue of the upper surface, and the strong brown tint of the under surface.

It appears to be confined to the Malay Islands. I liare seen no specimens from Queensland, where it may be rejlaced by Hewitson's species amytis. The figures given by Hewitson (Cat. Lycenidx, l. c.) do not belong to this insect, but to his adatha.

Arhopala kinitixil, n. sp. (Plate I. fig. 10, 0*)

Hab. 'Trobriand and Fergusson Islands.

Expanse, o* \& $\&, 54-58 \mathrm{~mm}$.

๙. Upperside: botd wings dark purplish blue; primaries with linear costal and outer margins; secondaries with a broad costa and linear onter margin, fold ample, greyish. 'Tail fairly stout, white-tipped. Underside: both wings warm brown washed with purplish, witl darker spots palely edged. Primaries with three increasing cellspots, the first one very small, below the third a largish one in the lower median angle ; transverse band composed of six confluent spots, each increasing in size up to the fifth spot, which latter is very large, the sixth spot tapers slightly towards the lower median nervule, the first four spots are outwardly oblique, the fifth and sixth. have their inner margins shifted well inwards, and below these is another smaller spot shifted inwards; submedian area paler; submarginal row fairly distinct, marginal row dark and almost coalescing with the submarginal in its upper part. Secondaries with a small spot at the extreme base of the costa and four small basal spots, the third shifted well outwards, followed by three large spots below each other, the lowest one being elongated somewhat outwardly ; cell closed by a large subquadrate spot, below which is another in the submedian angle connecting it with the clongated spot just mentioned; transverse hand composed of cight large spots, the first two extremely large, touching the spot closing the cell, the third shifted well outwards, fourth slightly out, fifth with its inner margin shifted far inwards, touching the bottom edge of the spot closing the cell, sixth spot shifted slightly outwards and larger, seventh angular spot very large and confluent with the eighth rery large rather long spot; submarginal row inclefinite; marginal row narow, just below the apex is a patch of dark brown clouding: a black spot at the anal angle edged above with bright metallic-blue scales, which are also scattered more or less along the margin up to and just beyond the tail.

․ Upperside: both wings brighter blue and paler than in the male. Primaries with a broad blackish costa, increasing in width beyond the apex of the cell; outer margin very broad; secondaries with a rery broal blackish costa and a rather broal 
outer margin, this margin is decidedly less broad than usual. Underside just like the male except that the ground-colour is paler, so that the markings stand out in greater contrast.

I have before me three males and one female of this insect from Mr. I)ruce's collection, and I have recently received other specimens from the same locality: it will come before centaurus Fabricius, but may easily be separated from that species by the difference in the blue and by the remarkable transverse bands in both wings on the underside; the general pattern and appearance are also different, and there should be no difficulty in recognising the species.

Ariopala centaurus (Fabricius). (Plate IV. figs. 10 \& 10 a.)

Pupilio centaurus Fabricius, Syst. Ent. p. 520. n. 329 (17\%5) ; id. Sp. Ins. vol. ii. p. 11\% . n. 5223 (1781) ; id. Mant. Ins. vol. ii. p. 68 . n. 616 (178\%).

Hesperia centaurus Fabrieius, Lnt. Syst. vol. iii. pt. 1, p. 2i5. n. 63 (1793).

Polyommatus helus Godart, Enc. Méth. vol. ix. p. 65??. n. 119 (18:23).

Polyommatus centaurus Godart, Ene. Métl. vol. ix. p. 658. 1. 138 (1823).

Amblypodia centaurus IIorsfield, Cat. Lep. MIus. E.I.C. p. 102. n. 33 (1829); IIewitson, Cat. Lycaenidae B.MI. p. 3. n. 15, pl. ii. figs. 10, 13 o (? figs. 12 ơ, 11 q) (186\%); Hoore, Proc. Zuol. Soe. Lond. 1865 , p. 775 ; Butler, Cat. Fab. Lep. B.A. p. 179. 12. 1 (1869); Druee, Proc. Zuol. Soe. Lond. 187t, p. 10z ; Butler, Trans. Limn. Suc. Lond., ser. 2, Zool, vol. i. p. 5 18. n. 1 (18\%7).

Amblypodia pseudo-centaurus Doubleday, List Lep. B.M. vol. ii. p. 24 (181z).

Narathura centaurus Distant, Rhop. Malay. p. 261. n. 1, pl. xxi. figs. 4 \&, 5 q (1885).

Nilasera centaurus Moorc, Journ. Linn. Soe. Lond., Zoology, vol. xxi. p. 44 (1886).

Arhopala centaurus, var. coruscuns Wood-Mason and de Nicérille, Jouru. A. S. B. vol. xlix. pt. 2, p. 234. и. $54(1880)$.

Amblypodia nakula Felder, Wien. eut. Monatsch. vol. iv. p. 395. n. 4 (1860); Druce, Proc. Zool. Soc. Lond. 1873, p. 35̃3; Kheil, Rhop. Nias, p. 33. n. 121 (1881).

Arhopala nakula Felder, Reise Novara, Lep. vol. ii. p. 22:2. n. 221, pl. xxix. fig. It (1865); Muore, Proc. Zool. Soe. Lond. 1877, p. 590, et 1878, p. 835; Wuod-MIason and de Nicéville, Journ. A. S. B. vol. 1. pt. 2, p. 251. n. 77 (1881).

Nilasera pirama Moore, Lcp. Cey. vul. i. p. 116, pl. xliii. figs. $3,3 \measuredangle \delta, 3 a$ o, $3 c$ larve and para (1881).

Nilesera pirithous Mloore, Proc. Zool. Soc. Lond. 1883, p. 531.

Arhopala centaurus de Nieéville, Butt. Ind. vol. iii. p. 234 . и. 786 (1890).

Narathura centaurus Fab., Hagen, Berl. ent. Zeit. xxviii. p. I52 (1892).

Arhopala centaurus Druce, Proc. Zool. Soc. Lond. 1895, p. 588, et 1896, p. 6z1.

Arhopala centaurus Fabricius, de Nicéville and Martin, J. A. S. B. vol. lxiv. pt. ii. p. $46+$ (1895).

Hab. India, E. Himalayas; Assam; Bhutan; Burma ; Malay Peninsula ; Siam ; South

India; Ceylon; Andaman Isles; Sumatra; Jara; Borneo; Sumba and Sumbawa.

Expanse, o\& \& , 58-6t mm.

This species and its various forms are now so well known that I will only make 
reference to those forms in which I differ somewhat from the conclusions arrived at by de Nicéville regarding them.

Cornscans (Wood-Mason and de Nicéville) and pirama Moore.-These two forms are the same; I can trace no difference whatever in the colour of either males or females from Ceylon and the Andaman Isles.

§. Upperside: both wings brilliant ultramarine-blue, sometimes paler at the base, but not always, with a very narrow black costa and onter margin.

q. Like the male in tone, but with the bases of the wings beautiful silvery greenish metallic blue extending over nearly half the surface, with costa and outer margin in the primaries very broadly black, increasing towards the apex; in the secondaries the costa is very broadly black and the outer margin by no means broad, but increasing in width towards the anal angle.

De Nicéville $(l . c$.$) says, referring to comscans: "The male may be known from$ A. pirama on the upperside by its more brilliant and lighter blue coloration, and in the female the brilliant basal blue portion is lighter and also better defined from the larker deep blue portion beyond." This is perfectly correct as regards de Nicéville's specimens, which, through his great kindness, I have before me; but it is not so at all with those I have had from my friend Dr. Staudinger and others, the males being precisely the same in every respect, and I have only one female to which it would apply-all the others from Ceylon are absolutely the same in each particular as those from the Andaman Isles.

Pseudocentauns Doubleday (amazona Pagenstecher).-This I take to be the Java form of centaurus, of which I have a number of specimens before me: the blue of some, not all, is rather brighter and bluer than ordinary centaurus Fabricins; it is, however, a curious fact that my only specimen, out of a great number, which is exactly typical with the type specimen of centaurus in the Banksian collection is one from Java, and is not of the dull purple of the common form, but rather brighter and bluer. The blue of these Javan specimens is not nearly so bright as coruscans, but it is of exactly the same shade as my Bornean specimens of centrumes Fab. and also as some specimens I have from Singapore and the west coast of Sumatra; the under surface is sonewhat more variegated, but this is so very variable throughout all the forms that no name can be based on it; pseudocentaurus and amazona must therefore be sunk under centaurus Fab.

The species being a very common one is also very variable, and it appears to me to serve no useful purpose to retain names for such a very slight variety as Doubleday's. It is one of the most widely distributed species of the genus, but unfortmately it is scarcely possible to state correctly the distribution of the type-form. Pirithous seems to occur mainly in Sikkim and Assam and on the eastern side of India. Besides these districts and Bhutan, I have it from Upper and Lower Burma; the type-form occurs with it in both these latter localities. Correscrans WVod-Mason and de Nicéville, as far 
as I can trace, appears to be confined to Ceylon and the South Indaman Isles, though a specimen I have from Nias comes very close to it.

The genitalia of all these are indistinguishable from each other, and they also are exccedingly close to $A$. micale Blanch.; the tegumen of centrums is not so large and the clasis less excised at the extremities.

Arhopala etrolis (Miskin). (Plate I. fig. 11, o.)

Amblypodiu eupolis Miskin, Proc. Limn. Soc. N.S.W. (2) v. p. 12 (1890).

Arhopala eupolis Miskin, Amals Quecnsland Mus. no. 1, p. 70 (1891).

IIab. Queensland, Tokal Key Island.

Expanse, $c$ is o , $52-58 \mathrm{~mm}$.

*. Upperside: both wings dull vinlet; primaries with the costa and outer margin very narrowly brown; secondaries with the costa widely and the outer margin very narrowly brown; abdominal fold grey. Tail longish, very broad, black, tipped with white; nervures on each side sliglitly elongated, so as to form rery short tooth-like frojections. Lobe moderately well developed. Underside: both wings dull, very pale brownish grey, uniform in tint, with darker spots palely encircled. Primaries with three increasing cell-spots, the third quadrate; below the second and third are two large spots divided by the lower median nervule; transverse band composed of siv confluent spots, forming an alniost straight fascia of equal width placed somewhat obliquely outwards; below the band is a seventh spot shifted inwards; marginal and submarginal bands very obscure. Secondaries with four basal spots, the lowest shifted in wards, followed by three smallish spots below each other; cell closed by a narrow subquadrate spot, below which is a small one; transverse band highly irregular and peculiar, composed of two large spots below each other which touch the narrow subquadrate spot, below this and shifted outwards is a broad irregular fascia ocempying the place of spots $3-6$ inclusive, the serenth angular spot is shifted inwards and is almost confluent with the eighth long spot; marginal and submarginal fascia very obseure: anal lobe blackish, edged above, and the space between it and the second median nervule filled in, with bluish metallic scales.

q. Upperside: both wings bright pale shining blue, darker towards the edges; primaries with the costa broadly blackish, increasing towards the apex, where there is a large blackish patch and the onter margin is very broadly blackish; secondaries with the costa very broadly dark brown and the onter margin narrowly so, but increasing somewhat towards the anal angle. Underside as in the male.

This species is eridently the dustralian form of centcums Fab. The colour above is duller and paler and the dark outer margin is of a wicth intermediate between that of that species and of pirithous Moore. On the underside the colour is rery much paler and is altogether more uniform in tone, the pattern is smaller in the primaries, there is no metallic edge to the cell-spots, and in the secondaries the lobe is mure VOL. XVII.-PART I. No. 6.-August, 1903. 
developed. The female closely resembles cornscans WV.-II. \& de N. in the coloration of the upperside. This is an interesting species, forming as it does a good " transit" to the species amatrix de Nicérille.

The hue of the underside varies somewhat, as in centanms Fab., being occasionally washed with violet or grey, but it is always quite pale in tone. The species has been known for years in the larger collections, having been placed either with amytis Hew. or centaurus Fab., but Mr. Miskin discriminated it in 1890. Until this year it has only been recorded from Queensland, but I have just received from Dr. Staudinger a perfectly typical female from Tokal Key.

Ariopala amatrix de Nicéville.

Arhopala amatrix de Nicéville, Journ. Bombay Nat. Hist. Sac. vol. ri. p. 3ro. no. 19, pl. G. figs. 23 đ, 24 \& (1891).

Ilab. Burma.

Expanse, ơ \& 우, 52-55 mm.

This species is a close ally of amantes Hew, but can be immediately distingnished by the broad black borders of the male, while the blue is not nearly so deep and brilliant. So far as is yet known, it is confined to Burma, but probably replaces Hewitson's species there; de Nicéville seems also to intimate this in his original description, for he says "True amantes apparently do not occur in Burma."

Ariorala ayantes (Hewitson). (Plate IV. figs. 11 \& 11 a.)

Amblypodia amantes Hewitson, Cat. Lycrenidæ B.M. p. 4. 11. 17, pl. ii. figs. 2 \& 3, of o (1862).

Arlopula amantes Wood-Mason and de Nicéville, Journ. A. S. B. vol. 1. pt. 2, p. 250. n. 76 (1881).

Nilasera amantes Moorc, Lep. Cey. vol. i. p. 115, pl. xliv. figs. $2 a, 26 \delta, 2$ o, $2 c$ larva and pupa (1881).

Nilasera apella Swinhoe, Proc. Zool. Soc. Lond. 1886, p. 429. n. 64, pl. xl. fig. 4 , q .

Hab. India; Ceylon; s. Andaman Isles; Makassar; Sumba; Timor; Babber Isles (Burma?).

Expanse, of \& क , 57-62 mm.

De Nicéville (Butt. Ind. vol. iii. p. 240) says it is widely spread throughout India, occurring " all along the foot of the Himalayas, in the plains of Bengal, the Central Provinces, and in Bombay, thence southwards to Travancore and Ceylon. Its flight is strong and rapid, and it conceals itself with wings always folded under leaves (IIutchinson)."

It is readily recognisable from ordinary centaums Fab. by the brilliancy of the blue and by the brighter females, but it is not so easily scparated from comscuns W.-M. \& de Nicéville. The blue is, however, deeper and more brilliant and the underside 
is not subject to such violent contrasts as in that insect, the tone being much more miform and the pattern more compact. Hewitson pointed out that the fourth spot of the transwerse band of the primaries was projected ontwards; this, however, is not itways so. I have specimens from sumba, Timor, and the Babber Islands, and in each of these the band is unbroken, though for all my specimens from the mainland and from Ceylon his remark is eorret; the anal lobe, moreover, is always very much more developed and is deep velvety black beneath. I have seen no specimen from the Andiman Isles. De Niciville says $(l$. c.) that he has seen one which is smaller and in which the area of the blue coloration of the upperside is different (dwes this mean the specimen was a fenale?), and all the markings below are smaller, more compact, and prominent. This specimen is not among those Mr. de Niciville kindly lent me, so I can only record his note.

[Since writing the forconing note on the Sumba, Timor, and Babber specimens, I have very carefully re-caminest them, and am inelined to regard them as a transit from this speeies to araxes Folder; the mprerside eolour is almost the colour of amantes, but the mulcrside juttern is that of Felder's insect. The range of true amantes will therefore be restricted to the mainlands and the Andaman Isles, the Makassar specimens I believe to be the transition form. In the genitalia the clasps assume a subtriangular form, whilst the base of the penis is angular instead of being almost straight.]

Ariomea araxes Felder.

Ar\%opale erraxes Felder, Reise Norara, Lep. p. 224, pl. xxix. figs. 3 \& 4 o , 5 q (1865).

Amblypudin wrexes IIewitson, Ill. Diurn. Lep., Lycenide, p. 11 a.

IIab. (Celebes, Mangioli, Sula Isles; Banka Isle.

Expanse, of 5:3, 오 $50 \mathrm{~mm}$.

$\therefore$ Upyerside: both wings brilliant morpho-blne, shating into purplish near the margins, in the costal, apical, and posterior marginal areas, costa itself tinely black, posterior margin less narrow. Sccondaries: costa broally blackish, posterior margin narrowly lilick, abdominal fold grey. Underside: both wings pale brown, with darkish spots with pale margins. Primaries with three discal spots increasing in size, all margined with bluish or silvery white except on their costal edges; below the spot closing the cell is a triangular spot, tonching the inner elge of which is a large spot in the paler submedian area followed by another near the base; transverse fascia ending on or below the lower incelian nervule and consisting of six, seven, or eight confluent spots regularly below each other with a slight ontward tendeney, the seventh and eighth sometimes detached; submaruinal row indistinct; the ground between these two lattrr faseice is greyish. Secondaries more uniform in colour with four basal spots, the second shifted slightly, and the fourth considerably inwards, the latter beyond but touching the internal nervure; outside these are two large spots below each other; cell 
closed by a quadrate spot, below which is a small triangular one; transverse fascia consisting of the following spots-two large upper almost confluent ones, two others below shifted outwards, fifth spot small, shifted inwards a little, sixth rery slightly outwards, the angular seventh spot well inwards and almost confluent with a lons eiglith spot which touches the internal nervure; submarginal row very indistinct; anal spot black, over which are scattered metallic-blue scales, as also over the marginal area up to the second median nervule, and these have an internal edging of dark brown hordered with white and following the course of the transverse fascia up to the interual nervure.

The second median nervure is elongated a little, so as to form a short tail beyond the white-tipped longish one.

․ Upperside: both wings rich dark brown; the primaries with a bright pale blue f atch on the lower half of the wing, extending two-thirds along the inner margin, while in the secondaries this blue patch extends almost to the posterior margin bolow the lower discoidal nervure. Underside as in male.

This species is very close to anantes, but may be distinguished from it at once by the very brilliant morpho-blue of the male, Hewitson's insect being very much darker ; whilst in the female of Felder's species the blue is very much less in extent, is not lustrous, and is paler. Felder also points ont another distinguishing character, viz. that the transverse band of the primaries is straight and not broken as in amantes Hew. Araces is also decidedly the larger insect of the two. I have specimens of it before me from S. Celebes, N. Celebes (Minahassa), Banka Isle, and Mangioli, Sula Isles, but I cannot trace it elsewhere, so that its distribution appears to be very confined and local.

Ariopala aglais Felder.

Arhopalu aylais Felder, Reise Novara, Lep. vol. iii. p. 223, pl. xxix. fig. 11, ठ (1865).

Amblypodia aglais Hewitson, Ill. Diurn. Lep., Lyc. p. 1ta (1869).

IIab. Philippine Islands.

Expanse, of \& $q, 56-64 \mathrm{~mm}$.

\%. Upperside: both wings deep blue with a slight mixture of purple with narrow black borders, the costa of the secondaries is rather broadly black. Abdominal fold up to the submedian nervure brown. The submedian nervure and the second median nervule is each elongated a little, so as to form a very short tail on each side the usual tail. Underside: both wings brown, paler on the primaries below the lower median nervule, all the spots very slightly darker brown and margined with whitish. Primaries with three largish discal spots increasing in size; below the spot closing the cell is another small one, and below that a third larger spot occupying the terminal 
portion of the second median and lower median spaces, and below the lower median nervule, beneath the second discal spot, is another spot, larger and more distinct than nsual: the slightly bent and uneven transverse band ends abruptly on the lower mediar nervule; submarginal row fairly distinct, with the iuner margin shaded with violet in the upper portion, which shading extends to the outer margin of the transverse band. Secondaries with four basal spots, the second and fourth shifted iuwards and outside these three large ones; cell closed by a large subquadrate spot, below which is another touching the lowest of the three. Transverse band irregular, extending to the internal nervure and consisting of two large squarish spots touching the spot closing the cell, four smaller ones shifter outwards; the next spot forming the angte is shifted inwarts and touches the spot extending up, to the internal nervure; submarginal row obsolete, but its position is indicated by the internal pale crescentic border; a large black velvety spot occupies the lobe and marginal space between the second and lower median nervules spriukled with brilliant metallic-green scales, which extend into the marginal area betwcen these two slots.

․ Upperside: dark brown, with a large patch of deep blue (not a tinge of purple in it) extending over a considerable part of the prinaries, but restricted in the sceondaries alnost to the area between the upper discoidal and submedian nervures. Underside as in male.

In the colour of the upperside this species is near micale Blanch., but is darker; it is, however, better placed here on account of the underside pattern, which is very dark and marked, the pattern being very prominently outlined with whitish and with no bluish metallic outline to the cell-spots of the primaries, so that there will be no difficulty in separating it from its near allies. Felder described it from Luzon and it appears to be confined to the Philippine Islands. In the genitalia the clasps are more ovate and the penis unusually short.

Armopala acetes (Hewitson). (Plate III. fig. 18, $0^{\circ}$.)

Amblypodia acetes Hewitson, Cat. Lycæenidæ B.M. p. 5, pl. iii. figs. 14, 15, \& (1862); id. Ill. Diurn. Lep., Lyc. p. 4 (1869).

IIab. Makassar, Celebes.

Expanse, o $64-67$, ㅇ $02-64 \mathrm{~mm}$.

This species can at once be recognised from aglais Feld. by its larger size, duller blue with merely linear black margins, and by its underside being much more uniform in tone and more spotted in pattern. It is one of the largest of the group and appears to be confined exclusively to Celebes and is a very distinct species. 
Arhopali camino (Moore).

Amblippodia camileo Moore, Horsfield and Moore, Cat. Lep. Mus, E.I.C. vol. i. p. 41. n. 58, pl. i $a$. fig. 6, \& (185\%) ; Hewitson, Cat. Lycenida B.M. p. 5. n. 23, pl. iii. figs. 25, 26, $\delta$ $(1862)$.

A.hopala camedeo Staudinger, Ex. Schmett, p. 280, pl. xeri., ơ (188s); de Nicéville, Butt. Ind. vol. iii. p, 250 (1890).

Ilal. Silkim tarai; Jalpaiguri; Assam; Chittagong Hills.

Expanse, of 5s-6t, ㅇ 60-60 mm.

This species can be recognised from any of its neighbours by the very pale lilac of its upperside, and by the pale grey of its underside with decided black spots encircled 1. istinctly with whitish. It is a beautiful and very distinct species and is not very (1) sely related to any, but is probably best placed here; de Nicéville says ( $l . c$.), "Oecurs in Sikkim tarii (not in the lills) in July and August; it is also found at Jalpraiguri and eastwards thronghout Assam, and the late Mr. H. M. Parish obtained it muly in the Chittagong Hill tracts. It appear's to be confined to the lower hills and ihe country at their feet."

Arhopala pades Felder. (Plate I. figs. 12 o , 13 ; ; Plate IV. figs. $12 \& 12 a$. )

Aryopeta parlus Felder, Reise Novara, Lep. vol. ii. p. 230.

Amblypodia viola Rüber, Iris, vol. i. p. 199, pl. ix. fig. 4 (188i).

Amblypudia padus IIewitson, Ill. Diurn. Lep., Lyc. p. 1+b. n. 79 (1865).

Hab. Halmaheira; Batchian; Banka; Mangioli, Sula Island.

Expanse, o 50-5:, ㅇ. $51 \mathrm{~mm}$.

c. Upperside: both wings pale lilac-blue, with fine black costal and posterior margins; in the secondaries the dark costa is rather broad. Abdominal fold pale urcyish. Tril black, tipped with white. Underside: both wings darkish brown, spots wecisely the same colour as ground, but broadly margined with whitish. In the primaries the space below the lower median nervule is pale greyish. Primaries with three discal spots increasing in size; above the second are two very small confluent spots and one small one above the very irregular and large spot closing the cell, while touching it beneath is a large one; the spot below the discoidal cell is large and distinct. The transverse band consists of four distinct spots-the first on the custa rery close to the terminal discal spot, the other three shifted outwards and outwarlly inclined, below which are two large spots shifted much inwards but with an outward inclination; immediately below these is a very small detached dot; the submarginal row of somewhat quadrangular spots distinct, extreme margin whitish. Secondaries with four largish basal spots below each other, the fourth shifted inwards, followed by three longer ones; cell closed by a large spot, below which and touching it is another shifted a little inwards ; the transverse chain-like fascia is composed of four jairs of spots. the upper of the costal two touching the upper one of the three larger 
spots mentioned before; the second two are shifted outwards, the next two inwards, and the final two further inwards again and quite detached from then; the last spot of these, touching the internal nervure and joining the angular one, is vory long an! extends almost up to the lowest basal spot; sulmarginal hunular row distinct. Lubrspot black; spot between the lower and second median nervules black, over which, as also over the marginal space between them, are bluish or greenish metallic scatus, Extreme margin finely white.

․ Primaries: upperside blackish, with a lare patch of very pale iridescent hl: extending a little beyond the discoidal cell to the imner margin and neculying ab ant two-thirds of the median area of the wing, in which area is a largish whits patch showir. through the iridescence. Secondaries: upperside greyish brown, with a pale slightly iridescent blue central area from the submedian to just over the discoidal nervure. Underside precisely as in the male.

These descriptions are taken from a male and female in my collection from Ilalmil. heira; the male agrees quite with Felder's type. I have male specimens from Butchiar which agree entirely with the type from Mangioli: however, the males differ slightly in having a broader suffused black posterior maryin to the primaries; in some specimns this border is rather narrow, but in others it becomes very broad from the lower me lian nervule up to the apex. The two fomale specimens I have before mo are entir ly brown all over, with a few superimposed pale blue scales on the basal area, in wir specimen only just sufficient to be seen, in the other more or less over the cell, and more thickly beneath the cell in the primaries only.

Herr löber described his species viola from langka, which is cridently only a slight variety of Felder's species; the colour is quite similar, but the apex and outer margin of the lower median nervule are broadly suftinsed with blackish. The insect is eridently variable both as to the width of the border and the tone of brown benenth: I haw specimens from Mangioli in which the border is moderately narrow, and others in which it is almost as wide as in the Bangka specimens of Röber; whilst beneath in som specimens the ground-colour is rather pale with the pattern slishtly outlined with whitish, and in others it is very dark with very marked whitish outlines. In Mancioli specimens the female is entirely brown with a slight scattering of pale blue scalc wer the basal area, and occisionally even these are almost obsolete.

This species has apparently not been recognised by anyone since Felder rescriberl it . all the specimens before me have been sent me as erillemes Feld. (a species about tivo. thirds its size), though the Felders in their work (l.c.) speak of it as reaching the sirt of camdeo Hew., and on the previous page they speak of crilanes as a third smatler than camleo.

There is now, however, no doubt as to the correct identity of each, for I hav examined the original types very carefully. The distribution is narrow; I have only seen specimens from Halmaheiru, Batchian, Bangka, and Mangioli (Sula Islands), an! 
can find no records of it at all. With a distinct species like this we may expect to find the genitalia somewhat specialised; as will be seen from fig. 12, Plite IV., the clasps are peculiar, and the tegumen is not so ample, whilst the penis is small.

Arhopala elfeta (Hewitson).

Amblypodia elfeta Hewitson, Ill. Diurn. Lep., Lyc. p. $14 b$, pl. iii $a$. fig. 40, \& (1865).

Hal. Suln (Celebes).

Expanse, + , $54 \mathrm{~mm}$.

ㅇ. Upperside: both wings brown, with a slight scattering of very pale silvery-blue scales over the basal area, not extending beyond the cell. Tail present but broken. Underside dull brown, with all the spots but slightly darker than the ground and distinctly encircled with pale greyish or whitish. Primaries with three large cell-spots, the third very large and irregular, extending down to the lower median nervule, with a very small spot above it on the costa. Transverse band consisting of six spots-first spot small, second, third, and fourth evenly and obliquely inclined outwards and shifted well out from the first small spot; fifth spot shifted well in wards, almost tonching the third large cell-spot; sixth spot below the fifth but with an outward inclination; below this is another very small spot; submarginal row fairly distinct, marginal row obscure; subdiscal area dark, submedian area pale. Secondaries with four large basal spots, the fourth shifted inwards; above the uppermost is another on the extreme basal edge of the costa; these are followed by three large spots below each other, the lowest being prolonged outwards. Cell closed by an irregular spot, below which is a small one in the lower median angle. 'Transverse band composed of eight distinct spots - the second shifted outwards, the third and fourth shifted outwards, fifth inwards, sixth outwards, serenth angular spot well inwards and touching the eighth which is unusually long and straight; submarginal row distinct and crescentic, marginal row fairly distinct; three blackish spots at the anal angle, the middle one almost covered with submetallic pale bluish scales.

This species is a very close ally of azut $a$ de Nicéville, of which at present only the male is known; the spots are larger, especially that closing the cell, but the pattem is similar, and I expect when more material comes to band that de Nicciville's name will probably fall as a synonym of this.

Arhopala azata de Nicéville.

A thopala azate de Niciville, Journ. A. S. B. vol. 1xiv, pt. ii. p. 466. n. 404 (1895); id. Journ.

Bomb. Nat. Hist. Soc. vol. x. p. 172. n. 21, pl. T. figs. 32 ơ, 33 ㅇ (1896).

Hab. Malay Peninsula (Perak); Sumatra.

Expanse, ơ, $48 \mathrm{~mm}$.

This species, coming between patus Felder and cridanus Felder, may be known from the former by its much smaller size, the colour of the upperside is very much 
darker and duller, the underside is close in both colour and pattern. From eridanus it can be separated in the same way as regards its upperside, whilst beneath it differs much more, Felder's species having a great deal more white, whilst this insect is more uniform and sombre in general tone.

Arhopala eridanus (Felder). (Plate I. fig. 14, ơ ; Plate IV. figs. 13 \& $13 \alpha$. )

Amblypodia eridanus Felder, Sitzungsber. Akad. Wiss. Wien, xl. p. 453 (1860).

Arhopala eridanus Felder, Reise Nov., Lep. vol. ii. p. 229, pl. xxix. figs. 16 \& 17 .

Amblypodia polita Röber, lris, vol. i. p. 199, pl. ix. fig. 14 (1887).

Amblypodia erielanus var. dilutior Staudinger, Iris, vol. ii. p. 123 (1859).

Amblypodia eridanus Feld., Hewitson, Ill. Diurn. Lep., Lycænidæ, p. 5 (1863).

Hab. Amboina, Palawan. Cagayan (a small island off the coast of N. Borneo), and Balabak.

Expanse. of \& 우, 46-50 $\mathrm{mm}$.

ס. Upperside: both wings pale hustrous violaceous blue, with very narrow black costal and posterior margins in primaries; in secondaries the costa is broadly blackish, posterior margin very narrowly black, abdominal fold to submedian nervure whitish grey. Underside: both wings brown, spots scarcely darker than ground, broadly encircled with white. Primaries with three discal spots increasing in size, that closing the cell very large and irregular, at the internal upper extremity of which and over the middle spot are one or two small white marks, indicating the trace of other small spots; on the costa directly over the large spot is a very small one and beneath the cell-spot is another largish one; below the middle discal spot is the nsnal one in the submedian area which is large and distinct; the transverse chain-like fascia is composed of one small spot on the costa, beyond which and quite detached are three chain-spots outwardly inclined, followed below by two more shifted inwards and detached from the three above; submarginal lunular row fairly distinct; extreme margin finely white. Secondaries with a half-spot on the extreme internal edge of costa, the white margin of which extends into a white short line along the costa; four longish basal spots below each other, the fourth being shifted inwards, followed by three others beyond; cell closed by a longish reniform spot, touching which below is another long spot; the chain-like fascia is composed of two spots generally touching each other, but not always. below which are four chain-spots, the third one shifted well inwards; the angular spot, detached and shifted inwards, touches the very long spot which almost reaches the fourth basal spot; submarginal lunular row distinct, a largish black spot occupies the lobe and the marginal space, above which and over the space intervening are scattered bluish-metallic scales. Extreme margin finely white. The second median nervule and the submedian nervure are slightly elongated, so as to form the trace of a tail on each side of the usual tail.

vol. XVII.-PART. I. No. T.-August, 1903. 
․ Upperside: both wings dark brownish, the primaries with a large patch of very pale iridescent blue from the discoidal to the submedian nervure and slightly on to the internal margin; in the posterior area a patch of white shows through the blue iridescence; there is a large dark spot closing the cell, which also shows through the iridescence and off which the blue scales are liable to get rubbed. Secondaries with the pale blue iridescence not extending quite so far towards the posterior margin. Underside as in male, but with paler ground and darker spots (in contrast) and the white encircling broader. In the primaries the spots over the middle discal spot and up to that closing the cell are quite distinct though irregular in shape, and the submedian area is whitish. In the secondaries there is a half basal spot on the extreme internal edge of the costa.

The type of this species, a single fenale, was described by Felder from Amboina. I have therefore described a male from that island and also a female agreeing almost exactly with the type ; the colour of the underside is not, however. constant in examples from the same locality-some from Amboina being quite pale brown, others dark brown; the pattern, however, appears not to be subject to variation. In the female the pale upperside patch occupies a greater or less area in different specimens quite irrespective of locality. Dr. Standinger has described a variety from Palawan as var. dilutior, of which I have the type male and female before me; the male is precisely the same as Amboina specimens of eridamus Feld., and the female differs only in the extent of the pale upperside, which is slightly greater than in the type-this, however, vanes in different specimens. Herr Röber has also described his species polita from Ceram (Iris, l. c.), the type of which is also before me, and it is absolutely the same as a specimen from Amboina, so that both these names must sink. I have before me, through the kindness of Mr. Cator, a series of eight specimens, tour males and four fenales, from Cagayan, which present no differences from evidemus Feld., except that the tone of colour of the male is distinctly bluer than usual. Dr. Staudinger calls his var. dilutior a small local torm of eridanus Feld.; this remark no doubt arises from the fact that he had not differentiated this species from the large patus of Felder, the two former being similar in size as well as colour and pattern. The genitalia are very similar to those of $A$. patus Feld., but the hooks attached to the lower part of the tegumen are recurved, as shown in Plate IV. fig. 13.

Arhopala carolina Holland.

drhopala carolina Holland, Novit. Zool. vol. vii. p. 78 (1900).

Hal. Buru Island.

Expanse, o\& \& 우, about $40 \mathrm{~mm}$.

I have not seen this species, which is described from specimens in Dr. Holland's collection. I admit it with some doubt, believing it will turn out to be merely a slight 
variety of eridanus Feld. Dr. Holland says it is like polita Röber (a synonym of eridanus), but the spots below, instead of being round, are elongated transversely. In many species of this genus I have noticed that the spots are occasionally liable to this curious malformation.

Arhopala opalisa (Moore).

Nilasera opalina Moore, Proc. Zool. Soc. Lond. 1883, p. 531, pl. xlix. fig. J, б.

Arhopala opalina de Nicéville, Butt. Ind. vol. iii. p. 257 (1890).

Hab. Khasia Hills.

Expanse, o, $38 \mathrm{~mm}$.

This species can be recognised at once from its neighbours by its small size and the quite distinct pattern of the under surface. It was described from a unique male specimen in the collection of Mr. Moore, which specimen is unique to the present time.

Arhopala viola Semp. (non viola Röber). (Plate I. fig. 7 , o; Plate III. figs. 29 \& 30 , ․)

Arhopala viola Semp. Schmetterl. Philip. i. p. 196.

Hab. Mindanao.

Expanse, o 36, q $36-37 \mathrm{~mm}$.

§. Upperside: both wings violaceous blue, slightly lustrous ; primaries with a narrow black costa and rery broad apical area and posterior margin, the latter becoming narrower at the anal angle; secondaries with costa broadish black, and posterior margin narrow; abdominal fold grey; from the submedian nervure up to the upper discal nervule is a narginal row of black luuules decreasing in size. Underside: both wings darkish brown, spots rather darker than ground, encircled, or partially so, with whitish. Primaries with two basal spots; the third closing the cell is not margined at its costal or anal edge with white, but occupies a large irregular area from the second subcostal to the lower median nervule; the transverse fascia consists of four confluent spots ontwardly inclined, below which are three more confluent spots shifted inwards and reaching almost to the inner margin; submarginal lunular row distinct, extreme margin finely edged with white; there is a small light patch near the anal angle on the inner margin. Secondaries with half a spot on the extreme upper basal edge, the white border of which extends shortly along the costa; beyond and below this are the four basal spots, the lowest shifted inwards on to the internal nerrure; ontside these are three largish spots, the top one of which is not margined with white on its costal edge; cell shifted inwards. Chain-like fascia rery irregular, the second spot shifted outwards, the third still further outwards, the fourth outwards somewhat again, fifth well inwards, sixth slightly outwards, the seventh spot at angle inwards, touching the long final spot, which nearly reaches the lowest basal one. This fascia is not absolutely 
fractured anywhere, though so irregular; submarginal lunular row distinct. A black spot occupies the lobe and the marginal space between the submedian and lower median nervures and between the latter and the second median nervule; the first and last are slightly edged above with bluish-metallic scales, and the middle spot has its entire central area filled with these scales, so that it appears as two little black spots at each extremity. Extreme margin finely white. Tail black, tipped with white.

․ Upperside: both wings pale azure-blue; primaries with very broad costal and posterior margins. Secondaries with very broad costal and posterior margins, the latter narrowing at anal angle; abdominal fold gres; anal angle with two black spots, lobe with a small black spot. Underside as in male, but spots more broadly encircled with white, and in the primaries the submedian area is all whitish, with the nsual spot below the middle discal spot. This area in the male is almost nuiform in colour with the ground. I have before me a second female in which the blue is deep slightly Justrons ultramarine, and the markings of the underside are not so conflnent, and the gromd darker brown.

A male and two females from Mindanao. Both these females are figured on Plate III. figs. 29 \& 30. E Mus. Standinger.

This species is much smaller than eridanus Feld., and may be known by this fact and also because the apex and onter margin are broadly blackish, whilst in the female the pale central area is not white but blue and is very restricted. The under surface is darker in both sexes, and with the white outlines of pattern narrower.

\section{Arhopala annulata (Felder). (Plate IV. figs. 16 \& 16 a.)}

Amblypodia anmulata Felder, Lep. Amboin., Sitz. Akad. Wiss. Wien, sl. p. t5:? (1860); Hewitson, Cat. Lycænidæ B.M. p. 9 (1862) ; id. Ill. Diurn. Lep., Lycænidæe, p. 5, pl. iii. fig. 21 (1865). Amblypodia tristris Röber, Iris, vol. i. p. 200, Taf. lx. fig. 9 (1887). Amblypodia erebina Staudinger, Iris, vol. ii. p. 123, Taf. i. fig. 14 (1889).

Hab. Amboina; Banka Island; Palawan and Saparua and Mindoro.

Expanse, of 32-38, ㅇ $35 \mathrm{~mm}$.

8. Upperside: both wings brown, with a few blue scales scattered over the basal half of the wings; in one specimen before me these blue scales occupy the whole of the basal, central, and submedian area, and in the secondaries the same area, but to a more limited extent. Tail brown, tipped with white, not long. Underside: both wings brown, with slightly darker spots encircled with whitish. Primaries with three discal spots increasing in size; below the spot closing the cell is another smaller one, and in the submedian area is another beneath the second discal spot; the transverse chainlike band is composed of seven distinct spots, all tonching each other, except that in the submedian area, which varies much in size. The first spot on the costa is very small, and is followed by three shifted outwards and outwardly inclined; the tifth is 
shifted well inwards; the sixth outwards again, immediately below which is the seventh detached spot. Submarginal lunnlar row distinct, beyond which is a marginal row of dark dashes interrupted at each nervure; extreme margin pale; subdiscoidal area slightly paler than ground. Secondaries: a half-spot at the extreme basal edge of the costa ; four basal spots below each other, the lowest shifted inwards, followed by three large spots; cell closed by a large. somewhat irregular spot, beneath which is a small triangular one shifted inwards; chain-like band composed of eight spots, the two costal ones inclined outwards, the next two shifted well outwards, tifth spot shifted decidedly inwards, sixth ontwards, the angular serenth spot sliglitly inwards, whence the long eighth spot runs upwards to the lowest basal one, which it sometimes tonches; submarginal lunular row distinct; marginal row less distinct; extreme margin finely paler; a dark spot occupies anal angle, the marginal submedian space, and the marginal space betwcen the lower median and the second median nervule, over which are slightly scattered, but more thickly in the central space. bluish-metallic scales.

q. Upperside: both wings as in male, but with a large central and basal and submedian area of superimposed pale bluish scales; this area is more restricted in the secondaries. In one specimen before me this area is whitish, tinged with lavender. A dark spot shows through, closing each of the cells. Underside as in male, but spots darker and more broadly encircled with white.

Dr. Staudinger's species erebina, from Saparna, agrees precisely with annulata in erery particular, and so does Röber's tristis from Banka-in fact, Hewitson's drawing might have been taken from Dr. Staudinger's type, they are so close. This species may be easily recognised from viola semp. by its brown colour and smaller size; the shape of the wings is also different, being narrower than in semper's insect. The female is variable; I have one in which the blue is quite bright (almost ultramarine), others almost brown, and one wlitish. The superimposed blue scales are evidently rubbed off easily in both sexes, and are often very sparse indeed. In the genitalia the same recurved (at the base) hooks appear as in eridanus, with subtriangular clasps and small penis.

Arhopala tephlis (Hewitson). (Plate I. figs. 15 \& 16, o; Plate IV. figs. 14 \& 14 a.) Amblypodia tephlis Hewitson, Ill. Diurn. Lep., Lycenidie, p. 14c, figs. 57 \& 58, of (I865) Amblypodia bicolora Röber, Iris, vol. i. p. 71, Taf. v. fig. 7 (1886).

Hab. Gilolo; Celebes; Halmaheira.

Expanse, of \& \& , about $47 \mathrm{~mm}$.

o. Upperside: both wings dull violaceons blue, with a not very narrow black costa and a broadish black posterior margin to the primaries, and fringes tipped with snowy white for the anal half. Secondaries with broad brown costa, and apex increasing in width at the anal angle; abdominal fold grey ; extreme margin in anal area bright blue; 
tail black, tipped with white, fringes tipped with snowy white; the submedian and lower median nervures are slightly elongated, so as to form two more very short tails, the upper one being the shorter. Underside: both wings brown, with spots marked ont by broad whitish margins, but in the primaries the spots are not encircled, though in the secondaries most are completely encircled. Primaries with three discal spots, the large irregular one closing the cell quite open above and below ; submedian area whitish; below the middle discal spot is another spot in the submedian space; transverse fascia marked out by three confluent spots, which are quite open above and below-these have an outward teudency; below are two more distinct confluent spots, shifted so much inwards that their onter margins touch the inner margins of the previous three-these two have a very broad internal white margin; immediately below them is a double crescentic dark spot; submarginal line distinct, between which and the upper three spots of the transverse fascia is a dusting of white scales. Secondaries with a half-spot at the upper basal extremity of the costa ; four basal spots below each other, the second and fourth shifted inwards, the latter being outside the internal nervure; beyond these are three large spots, the upper one of which is situated in a large whitish patch; cell closed by a large irregular spot, below which is a smaller one shifted a little inwards. The transverse chain-like fascia is composed of two very large upper spots, open above and below; the third, shifted right out on to the outer margin of the second, is very small indeed and entirely encircled with whitish ; the fourth, equally small and encircled, is again shifted on to the outer margin of the previous one; fifth smaller, still shifted inwards, below which is the sixth; the angular seventh spot much larger and shifted slightly inwards, and confluent with the eighth, which runs upwards to the internal nervure; following the course of this fascia is a dark submarginal line with an interior pale edging, and the space between the two is more or less suffused with whitish. Lobe-spot black, between which and the second median nervule the marginal area is covered with bright blue metallic scales, a very few being also sprinkled above and below the lobe-spot.

․ Upperside: both wings blackish brown, with a small brightish blue patch occupying the basal, submedian, and discoidal areas. Underside precisely as in male.

This is a common species in South Celebes, and is very distinct from all others, its nearest ally being bazaloides Hew.

This insect is subject to great variation, the form found in Celebes and in Halmaheira, named by Röber bicolora, being of a brighter blue and less violaceons ; it has very narrow black borders, the underside of which has very much less white and the spots are only margined very finely with white. I have, however, from S. Celebes specimens exactly like the type-form also.

Herr Röber had evidently overlooked Hewitson's inadequate description and also his figures; the two insects are identical. The genitalia are compressed, with the clasps larger and more rounded; the penis, with a trumpet-shaped orifice, is small. 
Arhopala bazaloides (Hewitson). (Plate 1. fig. 17; Plate 1V. figs. 15 \& 15 a.) Amblypodia bazaloides Hewitzon, Ill. Diurn. Lep., Lycænide, Suppl. p. 21, pl. vii. figs. $62 \& 63$. Arhopala buzalus de Nicéville, Butt. Ind. vol. iii. p. 2\$9 (1890).

Hub. Palawan; Mindanao; Zebu; Assam ; Trarancore and Canara.

Expanse. of 37, ㅇ $40 \mathrm{~mm}$.

đ. Uplerside : both wings deep purplish, with broad costal and posterior brown margins. In the secondaries these borders are decidedly broader than in the primaries; abdominal fold brown. Tail brown, white-tipped. the nervures on each side of which are elongated and form two very short tails. Underside: both wings brown, with the spots margined with whitish. Primaries with three discal spots increasing in size, that closing the cell being open above and below; beneath it is a short white dash; the transverse band is just discernible by the interior and exterior interrupted white margins; the upper three spots shifted outwards, the next two inwards, so that their inner edge touches the white dash just mentioned; helow this is a small dark submarginal row, fairly distinct; below the second discal spot there is a trace of another in the pale submedian area; apex with a few scattered whitish scales. Secondaries suffused more or less almost all over with whitish scales, with half a spot at the extreme hasal edge of the costa, the usual four basal followed by the three larger spots, the upper ones of these two series being confluent; ceil closed by a large spot, heneath which is a small triangular one. Transverse band indefinite, consisting of four pairs of spots: the upper pair heing dark and large; second pair small, indistinct, and projected outwards; third small pair shifted inwards, almost confluent with the seventh angular spot, which is also confluent with the eighth long spot, which latter is broken up into two, that touching the angular spot being small and round. There is a clistinct submarginal dark waved line; aual spot black; a black spot also between the submedian and lower median nervure, and between the latter and the second median nervule, -these two being covered with bluish-metallic scales, which also edge the anal spotabove.

․ Upperside: buth wings brighter purplish than in the male, with very broad, dark brown apical and posterior margins, and broad costa in primaries. In the secondaries the purplish is confined to nearly the area of the cell.

I have before me a male and two females of this Philippine form. There are decided differences between them and bicolore; it is only about three-quarters its size, the white margins of the spots below in the primaries are rednced so much as to become in some cases almost olsolete-the colour is quite different above and below; whilst in the secondaries the colour is also different, and the chain-band spots decidedly larger, though the insect is smaller.

In de Nicéville's collection are quite typical specimens from the Khasia Hills (Assam), Travancore, Canara; but he mistook Hewitson's species bazalus (his teesta) for this insect. The genitalia are similar to those of tephlis, but the clasps differ, as 
will be seen on reference to the figures (Plate IV. figs. $15 \& 15 a$ ), and the hooks have a decided upward curve at their extremities.

Arhopala theba (Hewitson). (Plate IV. figs. $17 \& 17$ a.)

Amblypodia theba Hewitson, Ill. Diurn. Lep., Lycænidæ, p. 6, pl. v. figs. $29 \& 30$ (1865).

Hab. Mindoro; Mindanao.

Expanse, of 41, 우 $42 \mathrm{~mm}$.

${ }^{*}$. Upperside: both wings brilliant pale morpho-blue, primaries shading into rich deep purple on the costa from the end of the discoidal cell to the apex and down the posterior margin to about the lower median nervule; costa narrowly black, posterior margin rather broadly black. Secondaries with a broadish dark costa; abdominal fold grey; posterior margin very finely black, and dotted with black between each nervure; tail black, tipped with white. Underside: both wings very dark brown, with the spots no darker than the ground, but marked out by broad white margins. Primaries with two discal spots not margined on the costal edge; the third spot, closing the cell, very large and irregular, is open above and below, and extends from the second subcostal on to the submedian nervule from the lower edge of the cell; the inner white margin is projected suddenly outwards so as to almost touch the outer margin on the lower median nervule; the transrerse band is irregularly marked out by the white margins, which rapidly taper from just below the lower discoidal nervure until they meet on the lower median; margin spotted with white between each nervule, with brown central dashes; submedian space whitish; the usual spot in the subdiscal area is present just below the second discal spot; there is a short white dash on the costal nervure up to the first discal spot. Secondaries with a half-spot slightly extended outwards on the extreme basal margin of the costa; four basal spots below each other, the lowest shifted inwards beyond the internal nervure, almost touching the margin itself; beyond these are three larger spots, the upper one not margined on the costal edge; cell closed by a large subquadrate spot, open above and below, beneath which the usual spot can be traced by its internal and external margins; the transrerse band marked out only by the lateral margins of the usual spots, but the margins are very irregular, thus the inner margin of what should be the second spot is projected well inwards, the margins of the third slightly outwards, and the fourth more outwards, the fifth well inwards, the sixth outwards, the angular seventh inwards and it is quite confluent with the eighth long spot, running up to the internal nervure; outside this fascia there is a suffusion of white scales; marginal row distinct the internal margin of which is very finely white; extreme margin white; anal spot black; spot between the second and lower median nervule black, the space between being filled with greenish-metallic scales, which are also scattered more or less over the spots.

ㅇ. Upperside: both wings brown, with a large pale blue patch over the basal and 
central areas, extending right into the inner margin in the primaries; this patch in the secondaries is larger in extent, extending further towards the posterior margin. Underside precisely as in male.

This very lovely species forms a natural comnecting-link, by its underside pattern, between bazaloides Hew, and the most beautiful (though not the largest in size) subgroup of the genus. From bazaloides Hew. it is immediately separable by its gorgeous colouring above, whilst below the pattern, though similar in character, is equally distinct in the very marked contrast of almost pure white and very dark brown. I have specimens from Mindanao as well as from Mindoro, so we may expect it to occur in other islands of the Philippine group. The genitalia are very distinct; the tegumen is not a hood, but is open at the top, and the laterals are small, the side supports being ample; the hooks are clouble-jointed, with the terminal arm sharply bent at the elbow: the clasps are curved and rather small, whilst the penis is long, slender, horn-shaped, with a trumpet-shaped orifice.

\section{Arhopala argentea standinger.}

Arhopalu argentea Staudinger, Exot. Schmett. p. 281, pl. xevi. (18s8).

Arhopale clarissa Grose-Smith, Novit. Zool. vol. iv. p. 366 (1897); id. Rhop. Exot., Lycænidæ, pl. xiv. figs. 4 \& 5 (1898).

Hab. Minahassa and South Celebes.

Expanse, of 45 , ㅇ $46 \mathrm{~mm}$.

I have, through my friend Dr. Standinger's kindness, his two types of this most unusual and lovely insect. The best description of the colour of the male is to call it mother-of-pearl, for it quite shows the greenish and mauve translucent tints of that material. It is at once separable from all other species by this colour. Mr. GroseSmith has since described it from South Celebes, so that it occurs both in the north and south of that island.

Arhopala saxgira Bethume-Baker. (Plate I, fig. 20, o .)

Arhopala sangira Bethune-Baker, Ent. Mo. Mag. vol. xxxiii. p. 202 (1897).

Hab. Sangir.

Expanse, ơ , $44 \mathrm{~mm}$.

This unique and beautiful little insect has only been recorded from the one island. It should be recognised at a glance whenever found.

Arhopala arostya (Hewitson).

Amblypodia aromya Hewitson, Ill. Diurn. Lep., Lỵcænide, p. 14 e, pl, iii $b$. figs. 45 \& 46 (1865).

Hul. Mindanao.

voL. xvil.-Part I. No. S.-August, 1903. 
Expanse, of \& $q, 46-48 \mathrm{~mm}$.

Hewitson's figures are very fair. I have a male from the same locality as his type, in which the colour is rather deep purplish blue, much deeper than usual.

Arhopala axthore (Hewitson). (Plate IV. figs. 18 \& 18 a.)

Amblypodia anthore Hewitson, B. M. Cat. Lyc. pl. iii. figs. 21 \& 22 (1862); id. Ill. Diuru. Lep., Lyc. p. $6(1865)$.

Arlopala anthore Hewitsoin, Staudinger, Exot. Schmett. p. 280, pl. xcvi. (1888).

Hub. Batchian, Halmaheira, and Ternate.

Expanse, of $4 \%-48$, of about $44 \mathrm{~mm}$.

From the preceding species anthore may be recognised by its larger size, brilliant blue, and by its underside being spotted rather than lined, as in Felder's species. From helius Cram. it may be known in that its underside is nuiform dark brown, the spots being merely narked out by the white edging, and no darker than the ground, whilst in Cramer's insect the spots are very decidedly darker than the ground-colour. The colour above is almost the same, but anthore Hew. is usually more suffused with purple in the primaries than is helius Cram. In distribution the species is very local though apparently plentiful where it occurs. I can trace it only from Batchian, Halmaheira, and Ternate. The genitalia have the tegumen hooded, extending right down to the extremities of the side supports; the hooks are straightish, the clasps suboval, and the penis small and slender.

Arhopala helius (Cramer). (Plate I. tig. 21 o , \& var. anthelits Stgr., fig. 22 o.) Papilio helius Cramer, Pap Exot. pl. cei. figs. F, G (1782).

Polyommatus helius Lucas, Lep. Exot. pl. xliv. fig. 4.

A'hopala phryxus Boisd. Voy. de l'Astrolabe, Ent. p. 75.

Amblypodia pleryxus Westwood, Doubl. \& Hewitson, Gen. Dium. Lep. p. 178.

Amblypodia helins Westwood, Doubl. \& Hewitson, Gen. Diurn. Lep. p. 478.

Amblypodia helius var. anthelius Staudinger, Exot. Schmett. p. 281 (1888).

Anllypodia tamyrus Felder, Reise Novara, Lep. vol. ii. p. 230, pl. xxviii. fig. 30 (1865).

Amblypodia helius Ribbe, Iris, vol. ii. p. 256 (1889).

Amblypodia sophax Nathew, Trans. Ent. Soc. Lond. 1887, p. 17.

Arhopala helianthes Grose-Smith, Rhop. Exot. vol. iii. p. 11, pl. xxv. figs. 5, 6, 7 (190:2).

Hab. Amboina; Aru; Tokal liey; New Guinea; Ceram; Waigeoe; Solomon Islands; Fergusson Island.

Expanse, ơ , 41-44 mm.

§. Upperside: both wings brilliant morpho-blue. Primaries shading into deep rich slightly purplish blue over the cell and in the apical area, and slightly on the upper half of the posterior margin; costa dark brown from costal nervure to margin, beyond extremity of nervure very narrowly brown; posterior margin less narrowly 
blackish. Secondaries with costa broadly grey; narrow brown posterior margin; abdominal fold pale grey. Underside: both wings pale brown, with a purplish shade in many parts; spots dark and velvety, broadly margined with whitish. Primaries with a pale submedian area; three discal spots increasing in size; above the outer edge of the second are two very small spots over each other; two or three are over the third spot; below this is another, and a trace of one in the pale submedian area below the second spot; transverse fascia consists of six confluent spots, the second shifted inwards, the third well outwards, the lower three below each other and shifted slightly inwards; there is sometimes just a trace of a small detached spot below the submedian nervure; submarginal row distinct. Secondaries with a half-spot at the extreme basal edge of the costa ; four basal suall spots, second and fourth shifted inwards, the fourth beyond the internal nervure, the first spot being a double one; beyond these are three large spots, the upper one being shifted right outwards, its iuner margin touching the outer margin of that below it, and the lowest spot ruus outwards into the seventh spot of the transverse fascia; cell closed by a large suboval spot; trinsverse fascia consists of nine spots, the second slightly shifted outwards, the confluent third and fourth right out, their inner margin touching the outer margin of the second, the fifth and sixth each slightly inwards, the usual angular seventh spot is divided into two, the upper of the two ruming into the lowest of the three across the central discal area, and the lower of the two-or the eighth, as I call it-confluent with the long spot which extends up almost to the lowest basal spot; submarginal band distinct, the white margins of which are rather suffused; lobe-spot black; spot between the second and lower median nervures black, the marginal space between which is broadly coloured with greenish-blue metallic scales which extend considerably over each spot; extreme margin whitish; tail stout, rather short, brown, tipped with white.

ㅇ. Upperside: both wings pale silvery azure-blue. Primaries with costa narrowly, apex very broadly, and posterior margin broad at first, then tapering to quite narrow, black. Secondaries with costa broadly dark grey, and posterior margin narrowly black. Underside as in male, but paler.

This species, which is one of the two on which Boisrluval founded his genus Arhopalu, may be known from anthore Hew. by the pale submarginal suffusion and by the fact that the markings are decidedly darker than the gronnd and are much more spotted in appearance.

Var. anthelius Standinger is a very pretty smaller form described from Aru and Waigeoe, but the Aru specimens are without doubt ordiuary helius; the Waigeoe specimens, however, are readily separable by the smaller size, especially noticeable in the females, and by the dark purple suffusion of the undersides, which is particularly prominent in the secondaries. Mr. Grose-Smith's helianthes, of which I have specimeus from Milne Bay, New Guinea, is referable to Staudinger's variety; it corresponds precisely with it. 
Arhopala minnetta (Butler).

Amblypodia minnetta Butler, Ann. \& Mag. Nat. Hist. ser. 5, vol. x. p. 152 (1882).

Hab. Duke of York Island; New Britain; New Guinea.

Expanse, ơ , $41 \mathrm{~mm}$.

This species is probably a local race of Aihopala helius, but is separable easily by the quite pale under surface and by the spots being somewhat smaller.

Arhopala albopunctata (Hewitson).

Amblypodia albopunctata Hewitson, Ill. Diurn. Lep., Lyc. p. $14 c$. 11. 89 , pl. iii $b$. figs. $43 \& 41, \delta$ (1869).

Narathure albapenctata Moore, Journ. Linn, Soe. London, Zoology, vol. xxi. p. 44 (1886). Arhopala albopanctata de Nicéville, Butt. Ind. vol. iii. p. 261. n. 821, frontispiece fig. 126 (1900).

Hab. Burma.

Expanse, o $37-44$, ㅇ $33-42 \mathrm{~mm}$.

The figure of the female given on the frontispiece by de Nicéville, in his · Buttertlies of India,' vol. iii., is not like Hewitson's female specimens; the underside markings are almost entirely disintegrated and practically resolve themselves into white spots and dots, though it is just possible to trace the sequence of the pattern, and there is scarcely any trace of the oval black spots at the anal angle of the upperside mentioned by him. This species can be immediately separated from lycanaria Feld. by the metallic morphoblue of its upper surface, which in the latter insects is somewhat shining pale violet, and the strong contrast of the dark ground and white spots and lots of the underside is very different to lycanaria.

Arhopala lycenaria (Felder).

Amblypodia lycenaria Felder, Wien. ent. Monatsch. vol. iv. p. 396. n. 8 (1860); Hewitson, Cat.

Lyc. B.M. p. 12. n. 54 (1862) ; Druce, Proc. Zool. Soc. Lond. 1873, p. 354. 1. 12.

Arhopala lycenaria Felder, Reise Novara, Lep. vol. ii. p. 232. n. 258, pl. xxix. fig. 13, $\sigma^{\pi}$ (1865).

Narathura lycenaria Distant, Rhop. Malay. p. 269. n. 15, woodeut n. 79, $\delta$ (1885).

Amblypodia olinda Druce, Proc. Zool. Soc. Lond. 1873, p. 354, pl. xxxiii. tig. 5, q.

Amblypodia buxtoni Hewitson, Ill. Dinrn. Lep., Suppl. p. 22. n. 104, pl. viii. suppl. figs. 68 \& 69 , $q$ (1878).

Narathur buxtoni Distant, Rhop. Malay. p. 464. n. 20, pl. xliv. fig. 18, ㅇ (1886).

Arhopale lyccenaria de Nicéville, Butt. India, vol. iii. p. 262.

Arhopula buxtoni, de Nicéville, loc. cit.

Arhopala olinda Druce, P. Z. S. 1895, p. 591.

Hab. Malacca (interior); Penang; Singapore; Borneo; Sumatra.

Expanse, of 34-35, ㅇ $36-39 \mathrm{~mm}$.

A. lyconaria is a species that has been rare hitherto; I do not think, however, that olinda Druce can be separated from it. Felder's original type is small and weak-looking; but I have other specimens before me, undoubted lyccenaria, that are 
fully as large as ordinary olinde and likewise almost identical in colour, whilst the general pattern of the underside is quite inseparable. They appear to obtain in exactly the same localities, and I think they must be synonymous.

Arhopala Alitels (Hewitson). (Plate IV. figs. I9 \& 19 «.)

Amblypodiu alitceus Hewitson, Cat. Lب̣c. B..11. p. \%. 11, 29, pl. v. figs. 45 \& 46, ठ (1862); id. III. Dinrn. Lep., Lyc. p. 8 (1865).

Amblypodia viriuna Röber, Iris, vol. i. p. 200, Taf. ix. figs. 13 \& 14 (1887).

Hab. Makassar; south Celebes; Banka; Mindoro.

Expanse, of 35, 우 $32 \mathrm{~mm}$.

Röber has described specimens from Banka as vivirna which, without doubt, belong to this species; both malc and female are exactly like Hewitson's insect in every particular, except that the posterior border of the latter is slightly wider. The form found in Celebes is much brighter blue, though dark, and not violaceous, whilst in the female the blue is brighter still and confined to a small spot just below and at the end of the cell of the primaries, and the underside is a little more strongly marked, but exactly the same pattern. Dr. Staudinger has sent me a specimen from Mindoro, and there is also one in Semper's Philippine collection. It is at once recognisable from its allies and is fairly well figured by Hewitson. The genitalia are less robust, the hooks are spatulate, the clasps subtriangular, with a moderately robust penis.

Arhopala mirabelia Doherty.

Aihopala mirabella Doherty, J. A. S. B. 1889, vol. lviii. pt. 2, p. 420. в. 13.

Hal). Mergui; Myitta.

I have not seen this species; from the description it appears to be an exceedingly close ally of aliteus Hewitson, so near that, without seeing the specimens, it is scarcely possible to differentiate them; but with species that are so close, as in this genus they are, an opinion can scarcely be formed in the absence of a good figure or the specimen itselt.

Arhopala myrtha (Staudinger). (Plate I. fig. 23, ơ.)

Amblypodia myrtha Staudinger, Iris, vol. ii. p. 127 (1889).

Heb. Palawan.

Expanse, ơ, $35 \mathrm{~mm}$.

o. Upperside: both wings deep ultramarine-blue, quite lustrous as it catches the light, but in some lights very deeply subdued. Primaries with a very broad blackish posterior margin; fore part of costa narrowly brown up to the costal nervure. Secondaries with broad blackish margins all round; abdominal fold greyish; tail black, tipped with white. Underside: both wings warm cinnamon-brown, spots and fascia scarcely darker than ground, palely encircled. Primaries: three discal spots 
increasing in size, below which are two spots separated by the lower median nerrule. and orer which are two indistinct small spots, with a third spot on the costa, that over the second spot beneath the costal nervure, between these, but further from the costa, is another indistinct dot; transverse chain-band composed of seven spots, first four detached from the three lower ones, the row of four is inclined outwards and the second and fourth spots are shifted outwards, the fifth and sixth are confluent, shifted well inwards, but with an outward inclination, the seventh spot smaller and indistinct; submarginal row fairly distinct; extreme posterior margin finely dark with a fine paler interior edge; submedian space paler. Secondaries with four basal darker spots, the third shifted outwards, followed by three larger ones below each other; cell closed by a large spot margined laterally, below which is a small triangular spot; transverse fascia with the first and second spot confluent, the second the larger, with its inner edge shifted well inwards and touching the spot closing the cell near the centre of its upper edge; third spot shifted well outwards, fonrth spot smaller, shifted outwards again, fifth inwards, its inner edge often almost touching the spot closing the cell, sixth slightly outwards, the serenth angular spot confluent or touching the eighth and shifted right inwards, its inner angle being very acnte and its inner upper margin almost touching the small triangular spot; submarginal row distinct; lobe-spot black; a black spot between the submedian and lower median and also between the latter and the second median nervule, which are almost obliterated by metallic-blue scales, which also edge the lobe-spot above and below; extreme margin finely brown with a fine interior edging of white.

This species may at once be recognised by the peculiar lustrous shading of the upper surface and by its unusually broad black outer margins, and also by the very irregular transverse band of the primaries beneath. I have before me three male specimens, all from Palawan.

Arhopala mindanexsis, n. sp. (Plate I. fig. 24, $0^{7}$.)

Hab. Mindanao; Mergui; Singapore.

Expanse, of 32-36, 우 $43 \mathrm{~mm}$.

§. Upperside: both wings deep sublustrous purplish violet, shading into lustrous brown in certain lights. Primaries: costa narrowly black, posterior margin with a broad black border. Secondaries with a very broad blackish costa and a broad posterior margin; abdominal fold pale brownish. Tail black, tipped with white. Tnderside: both wings greyish brown, with darker spots encircled with white. Primaries with three discal spots, the second rery large, quite as large as the third; below each of the latter two is another spot separated by the lower median nervule, that below the third having its white margin confluent with the inner margin of the third spot; between these two discal spots and the costa are three or four very small indistinct spots; transverse fascia composed of seven spots, the first on the costa small, the 
second larger, shifted outwards, third slightly inwards, fourth well outwards, these all having an outward inclination, fifth and sixth confluent and shifted inwards, seventh below the lower median nervule inwards again and irregular in shape; submarginal row almost evanescent at apex but more distinct towards the anal angle. Submedian area whitish. Secondaries with four basal spots larger than usual. Second and fourth shifted inwards, third ontwards, the upper three almost touching each other, followed by three larger ones, the lower two touching; cell clused by a large irregular spot, below which is a small triangular one; transverse fascia with the second spot larger than the first, its inner margin being shifted inwards (though I have one specimen with the onter margin shifted outwards, but in this the spots are all compressed together, being a small specimen), third spot shifted right outwards, fourth outwards again, fifth inwards, sixth outwards and tapering in shape, seventh angular spot right inwards, detached, and confluent with the eighth long spot; submarginal row distinct; extreme margin finely dark, edyed by an interior tine prale line; anal spot blackish, and a black spot between the second and lower median nervures, the space between which and also over each being filled with metallic greenish-blue scales.

?. Upperside: both wings purplish brown. Primaries with a small purple patch nccupying the discal and submedian area, but not below the submedian nervure. secondaries with a purple patch rery obscure and contined to the cell. I have one specimen before me withont any purple on the secondaries. Underside precisely as in the male.

This species may be known from mytha. itandinger by its deep purplish-violet colour and by the border not being half as wide. On the underside also it differs by its pale colour and by the distinct white edging to the spots, and also by a slight whitish suffusion in the secondaries; the transverse band is, moreover, less fractured and the spots larger and slightly different in position. The tone of blne raries somewhat, one specimen being decidedly bluer than the type. A female from Yergui in de Nicéville's collection is quite bright azure, and its underside pattem much more strongly marked.

Arhopala mrrtale (staudinger). (Plate I. fig. 25, o.)

Amblypodia myrtale Stgr. Iris, rol. ii. p. 126, pl. i. fig. 17 (non 16) (1889).

Arhopala myrtale Druce, P. Z. S. Lond. 1895, p. 592.

Hub. Palawan; Borneo (Sandakan and Labuan).

Expanse, of, $42-46 \mathrm{~mm}$.

The female of this species is not at present known. In his description Dr. Staudinger refers to some specimens doubtfully as the females, but he is so doubtful that he suggests the name myithe should be given them should they prove distinct. There is uo doubt that they are distinct, and, moreover, they are not females, but males haring broad borders. This and the paler blue will at once separate them from myrtrile; the 
latter is also a larger insect with a darker underside and a very much less broken-up transverse band. The same characteristics on the underside will separate it also from mindanensis B.-B., but the blue of my species is very decidedly darker and purpler and with broader borders than in myrtale. These three species are somewhat closely allied, but are, I believe, quite distinct and are easily separable.

The legend to the plate in the 'Iris ' $(l . c$.$) is incorrect: fig. 17$ represents myrtale and fig. 16 agesilaus.

Arhopala AIDA de Nicéville.

Arhopala aida de Nicéville, Journ. Bomb. Nat. Hist. Soc. vol, iv. p. 168. n. 7, pl. A. fig. 1, of ; id. Butt. India, vol. iii. p. 247. n. 802 (1890); Doherty, Jouru. A. S. B. vol. kviii, pt 2, p. 422. n. 21 ; Druce, P. Z. S. Lond. 1896, p. 666.

Hab. Burma; Labuan (Druce).

Expanse, ơ , $44 \mathrm{~mm}$.

The female of this species is at present unknown. De Nicéville describes $(l . c$. ) a female from Mergui, but is evidently doubtful as to its identity and notes certain differences. I have carefully examined his specimens and believe them to be a very strongly marked form of mindanensis, of which I have tive specimens from Mindanao; the female, however, is paler and brighter than my females, and the male is exactly the same above. Aida differs from myrtale Stgr. in its darker and more violet-blue and its broad outer margins; the undersides are, however, very much alike.

Arhopala dohertyi, n. sp. (Plate I. fig. 8, o* Plate IV. figs, 20 \& 20 a.)

Hab. Celebes.

Expanse, o* \& ㅇ, $3 \delta_{-42} \mathrm{~mm}$.

o. Upperside: primaries very dark deep blue, slightly violaceous, somewhat iridescent, with very dark and broad purplish-brown posterior margins, the blue has a very uniform and defined posterior margin following the comrse of the wing-margin; costa narrowly dark brown. Secondaries dark brown, with a small deep blue patch occupying the central area of the wing; abdominal fold greyish brown. Underside: both wings brown, with darker spots lightly encircled. Primaries with three increasing discoiclal spots; beneath the third is rather a large triangular spot; another small spot just beneath the inner end of the lower median nervule. Transverse chain-like band consisting of seven spots, of which the upper four have the inner edges uniformly curved outwards, but the onter edges of the two lower spots are projected outwards; the fifth and sixth spots are shifted well inwards and are followed by a smaller spot below the lower median nervule, usually, but not always, shifted slightly outwards; submarginal row distinct; extreme margin pale; submedian area greyish. Siecondaries with a small spot at the extreme basal edge of the costa, followed by the four basal spots below each other, the lowest shifted inwards beyond the internal nervure, three 
larger spots across the central discal area; cell closed by a subquadrate spot, below which is a smaller one connecting it with the third central discal spot; chain-like band composed of eight spots, the two distinct upper spots outwardly inclined, third and fourth spots confluent, shifted well outwards, fifth spot small, shifted inwards, sixth spot outwards, the angular seventh confluent with the long eighth spot which touches the internal nerrure; submarginal row distinct, extending very narrowly over the metallic spots up to the internal nervure, the light edging of which is more pronounced in the anal area; the black spots at the anal angle are almost entirely covered with metallic bluish-green scales np to the second median nervule: tail brown, tipped with white; submedian nervure very slightly prolonged, so as to form a very short tooth-like anal projection; extreme margin pale.

․ Upperside: primaries rich purplish black, with a patch of purplish blue occupying the cell, the submedian area, and about half of the posterior area below the upper median nervule. recondaries dark brown, with a small patch of purplish blne occupying about the discoidal area; tail darker, tipped with whitish; fringes grey. Underside as in male.

I have described the blue of the male as iridescent; this is not absolutely correct, but is the best term I can use, the one wing in the light looking very much brighter than the other, and in one particular light the wing looks lustrous brownish.

It is evidently a common insect in Celebes, judging from the number Mr. Doherty sent over here.

This is a rery distinct species and should be recognised at a glance on account of the peculiar blue of the male and its exceedingly broad onter margius, while on the underside of the primaries the upper four spots of the transverse band are peculiar, the first spot quite small, second rather larger, third and fourth very much larger; the whole of the underside is also very distinctly marked. The genitalia have the usual hooded tegumen and straightish hooks, the clasps are ham-shaped with squarish extremities. The penis is rather small for the size of the insect and is straight.

Arhopala labtaxt Bethune-Baker.

Arhopala labuana Bethune-Baker, Proc. Zuol. Soc. Loud. 1896, p. 667, pl. xxx. tigs. 12 o , 13 o.

Hab. Labuan; Mindanato.

Expanse, of 49, \& $44 \mathrm{~mm}$.

From dohertyi this species may be recognised by the brighter blue, very much narrower borders, much shorter tail, which is little more than a tooth-like projection, whilst below in the primaries the transverse band is not dislocated, but in the secondaries it is strongly dislocated. It is much nearer arzenius Felder, but is very much larger than that species; the distinctions are given in the description of that insect.

vol. xril.-PaRt I. No. 9.-August, 1903. 
Arhopala arzenius Felder.

Arhopala arzenius Felder, Reise Novara, Lep. vol. ii. p. 236, tab. xxix. fig. 18 (1865).

Hab. Luzon ; Batchian.

Expanse, ơ 40, 우 $41 \mathrm{~mm}$.

§. Upperside: both wings deep purplish blue, bright in some lights but exceedingly dull in others. Primaries with costa narrowly, outer margin widely, and apex very widely black; secondaries with costa broadly, and outer margin less broadly, black. Tail short, not much more than a tooth. Underside: both wings ochreous brown, with dark brown markings with pale ontlines. Primaries with three small but increasing cell-spots, below each of which is another ; transverse band of nearly uniform width, rather wide, nearly straight, but with a very slight outward inclination, composed of six spots, the first of which is so small and indistinct as to be nearly obsolete, the sixth spot ends on the lower median nervule; submarginal row distinct, composed of six spots terminating on the submedian nervure; submedian area very pale. Secondaries with four basal spots inwardly oblique, followed by four larger spots also somewhat inwardly oblique; cell closed by a subquadrate spot, below which is a small one connecting it with the third spot in the second series of four; transverse band composed of seven spots, the second of which touches the quadrate spot-hind spot shifted right outwards on to the outer edge of the second, fourth slightly outwards, fifth smaller oval spot inwards, sixth outwards, seventh angular spot well inwards; submarginal row distinct; a few metallic-blue scales near the anal angle.

․ Upperside: both wings paler violet-blue; primaries with the costa broadly, outer margins more broadly, apex yet more broadly dark fuscous; cell closed by a blackish dash; secondaries with the costa very broadly, and the outer margins less broadly, fuscons. Underside precisely as in the male, but the metallic-blue scales near the anal angle, very few in the male, are absent in the female.

From labuana this species may be recoguised by its much smaller size and by the broad borders of the primaries, while on the underside the transverse band of the primaries is of uniform width, absolutely unbroken and nearly straight, and there is scarcely a trace of the metallic-blue scaling at the anal angle of the secondaries.

Arhopala vihara (Felder). (Plate II. fig. 1, o*.)

Amblypodia vihara Felder, Wien. ent. Monatsch. vol. iv. p. 395. и. 5 (1860); Kheil, Rhop. der lnsel Nias, p. 33. n. 122 (1884).

Arhopalu vihara Felder, Reise Novara, Lep. vol. ii. p. 228. n. 253 , pl. xxix. fig. 7 (1865).

Narathura vihara Distant, Rhop. Malay. p. 2270. 1. 16, woodeut n. 80 (1885).

Arhopala vihara de Nieiville, Butt. India, vol. iii. p. 241 (1890); Betliune-Baker and Druee,

P. Z. S. Lond. 1896, p. 662.

Hab. Malacea; Nias Island, Borneo (Labuan and 'Tameang-Lajang), Sumatra, and Upper 'Tenasserim?

Expanse, o, 44 mm. 
$\therefore$ Upperside: both wings deep blue; primaries with a narrow black costa and less narrow black posterior margin; secondaries with a very broad brown apical area, tapering off towards the base of costa; posterior margin rather narrowly black; abdominal fold greyish brown. Underside: both wings golden brown, with dark spots palely margined. Primaries with three discal spots, beneath each of which is another, two below the median nervure, the third in the angle of the lower median nervule; transverse band composed of a curved row of forr confluent spots, followed by two larger spots shifted inwards and another much smaller one below the lower median nervule; submarginal row somewhat indistinet; submedian area paler. Secondaries with four basal spots, second and fourth shifted inwards, the latter beyond the internal nervure, followed by three larger spots; cell closed by a subquadrate spot, below which is a small triangnlar one; chain-like band composed of two distinct upper spots, the third and fourth confinent shifted right ontwards, fifth inwards, sixth slightly outwards, the angular seventh spot inwards and confluent with the long eighth; submarginal row fairly distinct, the pale edging of which is much more prononnced at the anal angle above the metallic spots; a black velvety spot occupies the anal angle, and a small dark one the margin between the second and lower median nervule, between which the space is filled with metallic-blue scales, which also edge the spots above; tail brown, tipped with white.

I have not seen a female of this species; it is a near ally of $A$. adorea de Nicéville, but may be recognised by its darker blue, rather wide black borders, whilst below it is decidedly darker in colour, and the transverse band of the primaries is rquite different in shape, which also applies to this band in the secondaries; the difference is, however, so difficult to convey in words that I must refer my readers to the figure; there is no costal spot in the primaries in firont of the transverse band.

In de Nicéville's collection I find several males from sumatra and I have two before me from Borneo.

Arhopala adorea de Nicéville.

Lrhopala adorea de Nicéville, Butt. Ind, vol. iii. p. 238. n. 789, pl. frontispiece fig. 139, $\delta$ (1890). Arrhopala adorea de Nicéville and Martin, Butt. Sumatra, Journ. A. S. B. vol. lxiv. pt. 2, p. 465. n. 391 (1895).

Hfab. Sikkim; Khasia Hills; Tenasserim Valley; Burma; Singapore; Sumatra; Malacca.

Expanse, of \& $f, 50-56 \mathrm{~mm}$.

There appear to be two forms of this species, one distinctly violet in shade, the other almost blue, and they have their respective females : beneath they are the same, but the colour above is readily separable; the blue form has rather broader outer margins than he purpler one, and I believe has often been confused with "vihari Feld.", with which it 
is very closely allied. It may be separated best by the underside pattern of the primaries, the spots being decidedly less than in Felder's insect, which latter has also a different transverse band beginning with quite a small spot on the costa, and the fifth and sixth spot being much larger and shifted further inwards. The genitalia are similar to those of dohertyi. but larger, with subtriangular clasps, and more slender penis which has a long opening at the orifice.

ARHopala Ph.enops Felder. (Plate I. fig. 27, 0.)

Arhopala phrenops Felder, Reise Novara, Lep. vol, ii. p. 227. n. 251 (1865).

Hab. Lnzon and Philippine Islands.

Expanse, of \& ㅇ, 36-39 mm.

This species is easily separable from adorea de Nicéville, for it is very much smaller in size and the transverse band of the underside is not dislocated, and it is altogether more uniform in tone of colour. From sandakani mihi it may be recognised by its much duller and darker upper surface and by the broader margins; beneath the colour is darker, the pattern is slightly different and is also more uniform than is my species. The figure will show at once the various points of difference. The genitalia are similar to those of dohertyi in pattern, but with smaller clasps rounded at the lower extremity but sharply angled at the upper extremity.

Arhopala sandakani Bethune-Baker.

Arhopala sandakani Bethune-Baker \& Druce, Proc. Zool. Soc. Lond. 1896, p. 671, pl. xxxi. fig. 2. ơ.

Hab. Sandakan; Java; Silam; Pulo Bai.

Expanse, o 35-45, 우 $42 \mathrm{~mm}$.

This species is easily separated from the following by its smaller size, narrower margins, brighter and bluer colom, and by the darker tone of the undersides. Since describing this species, Mr. Cator has taken many in Pulo Bai and one in Silam, Borneo. The genitalia are very similar to those of phenops, but the hooks are slightly curved upwards.

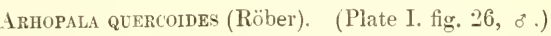

Amblypodia quercoides Röber, Iris, vol. i. p. 72, Taf. v. fig. 9 (1886).

Hab. Celebes.

Expanse, of \& ㅇ, $37-42 \mathrm{~mm}$.

This is a common insect in Celebes: in the male the violaceous colour has in certain lights a brown shimmer over it; it may be readily recognised from its near allies by its very much greyer under surface and rery distinctly marked pattern and the unusually even transverse band. The genitalia have oval extremities to their clasps, but are otherwise similar to those of phanops. 
Arhopala DRUcer Bethume-Baker.

Arhopala drucei Bethunc-Baker \& Druce, P. Z. S. Lond. 1896, p. 661, pl. xxx. figs. 1 o , 2 o.

Hab. Kina Balu, Bornen.

Expanse, of 55, o $50 \mathrm{~mm}$.

This is a very marked species and should be recognisable immediately; I have only seen a male and two females, all from Kina Balu, as mentioned in my original description (l.c.).

Arhopala apha de Nicciville.

Arhopala apha de Nicéville, Journ. Bombay Nat. Hist. Soc. vol. ix. p. 287. n. 21, pl. O. fig. 31, $\delta$ (1895).

Hiðb. Tenasserim; Burma; Lombok.

Expanse, ot 45-is, of $48 \mathrm{~mm}$.

This species is a very close ally of arlatha Hew., but its under surface is of a pinker and richer brown, whilst the spots are very much darker than in Hewitson's species. The upperside of apha is of a very much brighter and more shining blue and its outer border's are rather broader: there should be no difficulty in separating these species. I have recently received a pair of aph from Herr Fruhstorfer, taken in the Isle of Lombok.

Ariopala adatha (Hewitson).

Amblypodia adutha Hewitson, Cat. Lyc. B.11. pl. iv. figs. 29, 30, \& 31, o (1862); id. Ill. Diurn.

Lep., Lycenidæe, p. S. n, 28 (1805); Butler, Trans. Linn. Soc. Lond., ser. 2, Zoology, vol. i. p. 548. n. 4 (187\%).

Narathura adatha Distant, Rhop. Malay. p. 265 (figures incorrect) (1885).

Arhopala adatha de Nicéville, Butt. Ind. vol. iii. p. 247.

Hul. Amboina; Nalacca; Singapore; Celebes; Philippine Islands (Mindanao aud Mindoro).

Expanse, of \& $f, 48-54 \mathrm{~mm}$.

๙. Upperside: buth wings dark, somewhat purplish blue, primaries with costa narrowly and posterior margin less narrowly black, secondaries with costa very broadly and posterior margin rather narrowly blackish; lobe spot black, edged above with whitish; tail blackish, white-tipped. Underside: both wings rufous brown, with dark spots palely encircled. Primaries with three increasing discal spots; above the third is a small spot on the costa and below it (the third) is another in the lower median angle, the subdiscal area is darker; submedian area quite pale up to the submarginal row; transverse band oblique, composed of six confluent spots, the first on the costa being the smallest, the second, third, and fourth are continuous, fifth very slightly shifted inwards, 
sixth ending on the lower median nervule shifted slightly outwards, below this is a detached or occasionally almost detached spot; submarginal row obscure, but quite perceptible: marginal row almost obsolete. Secondaries with four basal spots, the fourth beyond the interual nervure, followed by three larger spots below each other; cell closed by a large subquadrate spot, below which in the lower median angle is another very narrow spot; two large spots below each other from the costal nervure to the subquadrate spot, the lower one of which also touches the transverse band, which begins on the upper discoidal nervule and is composed of two curved confluent spots edged laterally, followed below by the third spot shifted inwards, fourth shifted outwards, fifth angular, shifted right inwards and completely confluent with the sixth long spot, so that it appears as an angulated fascia with one side abnormally long; submarginal row obscure; marginal sublunulated row likewise obscure; lobe-spot black, followed by two other black marginal spots, which are almost entirely obliterated by bronzy-green metallic scales, which also edge the lobe-spot above, the metallic scales being margined above with very pale greyish.

ㅇ. Upperside: both wings dark purplish brown, with a very large patch of rather brighter purplish blue occupying the cell, the submedian and three-fifths of the median areas of the primaries, and in the secondaries just over the cell and about two-fifths of the median area; the blue of the primaries is invaded at the end of the cell by a wedge of ground-colour. Underside precisely as in male.

There has been considerable confusion with this species, which was figured by Hewitson as adatha in his Cat. Lycrenide B.M. pl. iv. figs. 29-3I, but in the text was sunk under micrle Boisdural, and in his Ill. Diurn. Lep., Lyc. p. 8, was raised to specitic rank again, but without any remark. His type labelled adatha from Amboina is quite evidently that shown as figure 31 , which is a very fairly accurate figure. Had it been left thus the matter was perfectly simple, but unfortunately Mr. Distant refers to it in his work Rhop. Nalay. p. 265, tab. xxiii. figs. 18,2 o , thus:- "The figures here given are those of a male and temale specimen captured in Malacca by Captain Pinwill and now contained in the British Museum ; these figures do not altogether correspond to those given by $\mathrm{Mr}$. Hewitson as representative of his species. I have, however, carefully compared them with the type specimens of Hewitsols, and find that they are correct and faithful." In Hewitson's collection there is one specimen labelled allatha: this Mr. Distant, I doubt not, has called the type specimen; I have done it likewise, more especially as Hewitson's figure $3 I$ is quite evidently drawn from it; but how Mr. Distant can consider his figures are "correct and faithful" to it, I cannot understand-they have no resemblance whatever, either in form, colour, or markings, to Hewitson's specimen labelled adatha; they evidently depict an insect belonging to quite a different section of this genns. But are tigures 29 and 30 the same species as 31 ?-de Nicéville considers them probably distinct (vide Butt. India, l. c.). I feel however, that I really cannot separate them. All the Amboina specimens have the 
transverse band of the primaries unbroken, and one specimen from Minatiassa (Celebes) has this band likewise unbroken, inother has it slightly fractured at the fifth and sixth spot, whilst several Philippine specimens have similar slight fractures, but one from Miudoro has the band distinctly fractured and is exactly represented by figure 29 from Singapore: otherwise both in size and colour they are just the same and also as to the width of the margin. Under these circumstances I do not see any advantage in splitting the forms up, as, until we have very much more material there can be no certainty of being correct in so doing.

The identity of adathe Hew, is, howerer, quite settled, and I feel myself that the other is merely an aberration, perhaps a gradual setting up into a local form of the same species.

There is nothing unusual about the genitalia.

Arhopala malayica, 11, sp. (Plate 1I. fig. 2. 0 o.)

Hab. Philippine Islands; Java.

Expanse, of $d$ \& , $50-58 \mathrm{~mm}$.

8. Upperside: both wings deep purplish blue, primaries with the costa rather narrowly brown and onter nargin rather wider and blackish, secondaries with the costa broadly and the outer margin not very narrowly blackish. Tail long, black, tipped with white, the nervule on each side of it being elongated so as to make a slight tooth; lobe well developed, with a black spot edged slightly above with metallic blue. Underside: both wings ochreons brown, with dark spots palely edged. Primaries with three small but increasing cell-spots; below the third is a large one in the lower median angle; subdiscal area dark with a very faint paler spot in the middle; transverse band narror, composed of six confiuent spots, with a very slight outwardly oblique inclination. the band being nearly straight, except that the fourth spot is curved very slightly outwards and the fifth spot has its inner edge shifted shightly inwards below the sixth spot; in the pale submedian area is another spot (divided into two in the type male, but not so in the female) shifted inwards; submarginal row distinct but indefinite. Secondaries with small spot at basal extremity of costa; four quite small basal spots, the third shifted well outwards, followed by three larger spots below each other; cell closed by a largish spot, below which is another in the lower melian angle; shifted well out from the spot closing the cell are two spots which usnally form the upper two spots of the transverse band between the costal and upper discoidal nervures, the two spots are isolated and confluent, the second being the larger; the transverse band beginning on the upper discoidal nervule and shifted right out is composed of six spots, the first four almost confluent, but with the second having in the type, but not always so, a slight outward shifting and the third a very slight inward shifting, the fifth angular spot confluent with the long sixth spot is shifted right inwards; submarginal row broad and fairly distinct; lobe- 
spot large, velvety black, and a deep black spot beyond the tail, well covered, as is also the space between the two spots, with bright pale bluish-metallic scales, which likewise edge the lobe-spot above.

ㅇ. Upperside: both wings violet-blue; primaries with very broad black costa and outer margin, and yet broader apical area; secondaries with very broad margins all round. Underside like that of the male, except that the ground-colour is rather paler.

One specimen from Mindoro has the costa and outer margin of the primaries decidedly narrower than in the type.

This species comes between adatha Hew. and silhetensis Hew. ; on the upperside it has wider borders than the former but rather narrower than the latter. In general pattern of the underside it is more like adatha, but has the spots nearly half the size and very much darker, thus forming a decided contrast with the ground-colours, and the transverse band of the secondaries is quite different, this being caused by the isolation of the upper two spots. The spots are also decidedly smaller than in silhetensis; there is also no spot on the costa of the primaries, and the transrerse bands in both wings are not dislocated as they are in that species. In the genitalia the clasps have conical extremities.

Arhopala silhetensis (Hewitson).

Amblypodia silhetensis Hewitson, Cat. Lycænidæ B.M. p. 7. n. 31, pl. iv. figs. 27, 28, of (1862).

Arhopala silhetensis de Nicéville, Butt. Ind. vol, iii. p. 237 . 1. 788 (1890).

Arhopala arama de Nicérille, Journ. Bombay Nat. Hist. Soc. vol, ix. p. 285, u. 20 (1895).

Hab. Sylhet; Sikkim Dooars, Sikkim; Burma (? Cochin China).

Expanse, of \& ㅇ , 49-54 mm.

o. Upperside: both wings deep purplish blue; primaries with the costa narrowly and the posterior margin broader black; secondaries with the costa very broadly and the posterior margin less broadly, but increasing at the anal angle, black; abdominal fold very broadly brown; lobe well developed: tail blackish, tipped with white. Underside: both wings dull brown, with darker spots bordered with blackish with an outer encircling of white. Primaries with three increasing cell-spots; above the third near the costa is a small one, and below it (the third) another; subdiscal area dark, with a paler spot in the middle; submedian area paler; transverse band composed of seven spots, the first four placed obliquely outwards and slightly curved, the second and fourth being the largest, fifth and sixth spots shifted well inwards, but with an outward inclination, the seventh elongated spot is also shitted inwards, submarginal row distinct. Secondaries with a spot at the basal costal extremity, and the usual four basal spots, the fourth shifted inwards, followed by three larger ones below each other ; cell closed by a subquadrate spot, below which is a small one, and above which are two confluent spots, the lower larger than that next the costa, these usually forming the 
first two spots of the transverse band, which band begins on the upper discoidal nervule. composed of six spots, the second shifted ontwards, the third well inwards, fourth ontwards, fifth angular spot right inwards, detached and tonching the sixth long spot which extends וㅏ to the internal nervure; lobe largely developed; lobe-spot black finely edged above with metallic-blue scales, which extend slightly into the nervule interspace beyond, above which is a broad dash of greyish scales; snbmarginal row obscure.

9. Paler, and the blue more riolet in shade ; in the primaries the costa and posterior margins are very broadly, and the apex yet more broadly, purplish black; the secondaries have exceedingly broad margins all round. Underside as in the male. In the Hewitson collection is a female, labelled Cochin China, in which the blue is much brighter and paler than usual.

A. sillietensis can be separated from malayica mihi by the pattern beneath; the spots are all larger, the transverse band of the primaries is distinctly fractured (whilst in my species it is not), and the transverse band of the secondaries is different, the third, fourth, fifth, and sixth spots being twice fractured, but being in maluyica almost confluent; there is also a distinct black spot in the lower median nervule space in my species, absent in Hewitson's, and his species has only a trace of a very sparse metallic scaling, wherens mine has an abundance of bright blue metallic scales. From niceillei it is easily separable becanse of the violet colour of that speciess, and by the pale greyish underside with the blackish spots standing ont in strong contrast to my species.

'This little group of four species allied to adatha Hew. has been difficult to arrange: adatha Hew., malayica mihi, sithetensis Hew., and nicérillei mihi are all closely allied yet quite distinct in the appearance of the underside; of mulayica I have nine specimens, and of nicévillei five, each constant in pattern: aphu de Nicéville is closc also, but I think there is no doubt that they are distinct from each other.

A. areme of de Nicéville falls as a synonym of this species. My friend Mr. de Nicéville had uever scen this species, and from Hewitson's description he mistook the insect. I have carefully compared his type of arama with Hewitson's insect, and find that they agree absolutely.

Under the circumstances I have thought it well to describe these fully, more especially as this last species is very rare and Hewitson's description is very inadequate.

Ariopala aicévillia, n. sp. (Plate II. fig. 3, §.)

Hab. Burma and sikkim.

Expanse, of 56, ㅇ 48-56 mm.

¿. Upperside: both wings violet-blue, slightly lustrous, in certann lights dull violet; primaries with the costa and outer margins narrowly dark fuscous: secondaries with the custa and abdominal margins broadly and the onter margin very narrowly dark fuscuus; abdominal fold grey; lobe highly developed, with a blackish spot; VOL. XVII.-PART 1. No. 10.-August, 1903. 
tail long, dark fuscous, tipped with white, nervures on each side of this being slightly elongated into a tooth-like projection. Underside: both wings greyish ochreous brown, with very dark brown, almost blackish spots encircled with whitish. Primaries with three increasing cell-spots; above the third a small one near the costa, and below it (the third) a large one in the lower median angle; a very large subdiscal spot, with a pale centre in it; submedian area pale grey. Transverse band composed of seren spots, highly dislocated between the fourth and fifth; the second spot is large and shifted outwards as to its outer margin only, third spot smaller with its outer margin consequently inwards, fourth spot shifted somewhat outwards altogether, fifth spot shifted right inwards, with its outer margin on the inner margin of the fourth spot, sixth long spot shifted slightly ontwards, seventh spot shifted inwards, but with an outward inclination; submarginal row distinct, but indefinite. Secondaries with a spot at the basal costal extremity ; four basal spots, the lowest shifted inwards, followed by three larger spots below each other; cell closed by a large quadrate spot, below which is another connecting it with the lowest of the three afore-mentioned; above this cellspot, touching it, are two large spots above each other, extending up to the costa; these nsually form the first two spots of the transverse band, but in this species they form an inner fascia with the cell-spot, the small one below it, and the third spot of the series of three. Transverse band beginning on the discoidal nervure, composed of four spots and a large crook-shaped mark; the second spot is shifter ontwards, third slightly inwards, fourth slightly outwards, the crook-shaped mark, composed of the angular spot and long spot combined in one, shifted right inwards and extending nearly up to the lowest of the basal spots. Submarginal row indefinite; lobe-spot deep black, with a slight black marginal spot in each of the next two nervure interspaces, over which latter are superimposed greenish-metallic scales, which also edge the lobe-spot above; between these and the transverse band there is a slight scattering of greenish-grey submetallic scales on a darker background.

\&. Upperside: both wings a little bluer than the male; primaries with broad costa, broader onter margin, and very broad black apical area: cell closed by a black dash: secondaries with very broad black margins all round. Underside: both wings precisely as in the male.

This species, of which I lave five specimens before me, is nearest sithetensis Hew., but may be readily distinguished by the paler violet-blue and the very narrow black borders to the primaries; beneath it is much paler and greyer, whilst the blackish spots, all standing out most prominently, make it recognisable at a glance.

Arhopala nobilis (Felder). (Plate II. figs. 4 o , 5 q.) Amblypodia nobilis Felder, Sitzb. Akad. Wiss. Wien, xl. p. 453 (1860). A $\cdot$ hopala nobilis Felder, Reise Nov., Lep. vol. ii. p. 226. n. 219, tab. xxix. fig. 6 (1865). 
Amblypodia nobilis Hewitson, Cat. Lyc. B.M. p. 7. n. 33 (1862); id. Ill. Diurn. Lep., Lyc. p. 8 $(1865)$.

Amblypodia alce Ribbe, Iris, vol. ii. p. 956 (1899).

Arhopala alcestes Grose-Smith, Rhop. Exot. vol. iii. p. 9, pl. xxv. fig. I.

Ilab. Amboina; Ceram.

Expanse, of $4 \bar{t}$, ㅇ $49 \mathrm{~mm}$.

o. Upperside: both wings shining ultramarine-blue; primaries with a very narrow black costa and narrow posterior margin. Secondaries with broad blackish costa, narrow posterior margin, blackish-grey abdominal fold; anal angle with a large black spot; tail black, white-tipped, a short black tail also at the end of the scond median nervule; lobe highly developed, black, edged above with brilliant cærulean. Underside: both wings warm brown, with dark velvety spots palely edged. Primaries with threc large and increasing spots, the second not cdged on its costal side, and the third edged laterally only ; anterior to the second and over the third are two small spots on the costa; bencath the sccond spot in the paler submedian area is a darker shading forming a very indefinite spot: transverse band composed of six spots, a small costal one confluent with the much larger sccond spot; third and fourth larger still, shifted well ontwardly, confluent, with no outward pale erlging, but diffused right into the submarginal row, the upper of these two spots forms an interior obtuse angle with the lower one; fifth spot shifted right inwards, the sixth also slightly inwards and terminating on the lower median nervnle; submarginal row distinct. Secondaries with a small spot at the costal base; a large, irregular, basal spot, followed by two small roundish ones, the lower one being shifted beyond the intemal nervure; these are followed by three longish spots below each other; cell closed by a subquadrate spot, below which is a small, very dark spot in the lower median angle. Two large confluent spots are just below the costa, which shonld form part of the transverse band, but are quite disconnected from it; the upper one touches the middle spot, and the lower one touches the spot closing the cell. Transverse band begins on the upper discoidal nervure with two confluent quadrate spots, followed by the third shifted well inwards, the fourth outwards, fifth angular spot slightly inwards and confluent with the sixth long spot; submarginal row almost obsolete. Lobe-spot large, velvety black, and more or less black in the marginal spaces between the three succeding nervules, over which is a considerable suffusion of greenish-metallic scales, which are edged above by a black stripe up to the internal nervure; over this again are more metallic-greenish scales mixed with grey ones. Most of the spots on the secondaries have pale centres.

ㅇ․ Upperside: both wings bright azure-blue, with broad purplish-black costal and posterior margins to the primaries, and broad margins all round in the secondaries. Underside as in male.

This specics is very close to alce Hew., but the blue of the upperside is much brighter and of a different tone, and the undersicle markings are much less and are not 
at all confluent as in Hewitson's insect. The shape of the wings is also different, the apex of the primaries being sharper, the posterior margin straighter, whilst the secondaries are more excavated towards the tails. Alce also has the black margins less narrow than in this species. IJerr Ribbe recorded alce from Ceram (Iris, l. c.), but I have the specimens before me, and they are nobilis. Alcestes Grose-Smith must sink as in synonym of Felder's species; the underside pattern is quite similar, the only difference being the whitish patch by the subcostal nervule of the secondaries, and as there is sometimes a lightening of the scales there it can only be a pale aberration.

Arhopala Alce (Hewitson). (Plate V. figs. 1 \& 1 a.)

Amblypodia alce Hewitson, Cat. Lyc. B.M. p. 5. n. 21, pl. iii. $q$ figs. 18, 19. o 20 (1862); id.

III. Diurn. Lep., Lyc. p. 4, fig. 9 (1865).

Arhopala athara Grose-Smith, Rhop. Exot. vol. iii. pp. 9, 10, pl. xxv. fig. 2.

Hab. Aru; Halmaheira.

Expanse, o 50-51, 우 $60 \mathrm{~mm}$.

This is probably a local form of nobilis Feld., and both appear to be rare species. It may be separated by its larger size, brighter blue colour, and below by the extremely large size of all the spots, which are much confluent, and at the base of the seeondaries are strongly so, and they thus form a very irregular, dark, basal blotch. I camnot find any distinction between $A$, athara Grose-Smith and alce Hew. ; the position of the spots mentioned by Mr. Grose-Smith is by no means constant in Hewitson's species, of which I have before me a fair series, so that it would not be possible to separate them on this character ouly. The clasps of the genitalia are peculiar, becoming attenuated at the extremities; the hooks have a downward curve.

Arhopala anunda Hewitson. (Plate III. figs. 19-21; Plate V. figs. 2 \& 2 a.)

Amblypodia anunda Hewitson, Ill. Dium. Lep., Lyc. p. 14a. n. 73 , pl. iii $a$. fig. 32.

Narathura anthelus Distant, Rhop. Malay. pl. xxiii. fig. 4, $q$, and in parte p. 263.

Amblypodia anthelus var. saturatior Staudinger, Iris, vol. ii. p. 122.

Hab. Borneo; Philippines (Mindoro, Mindanao, Palawan); Sumatra and Java.

Expanse, ơ 45-52, 우 46-51 mm.

8. Upperside: both wings brilliant shining violet-blue; the primaries with black linear costa and posterior margin; secondaries with broadish brown costa, linear black posterior margin, and very pale grey abdominal fold. Tail black, white-tipped. Underside: both wings pale greyish brown, with dark spots broadly edged with whitish. Primaries with three large increasing spots, tonching the second of which are two or three somewhat confluent spots up to the costal nervure; over the third is a largish spot on the costa, and anterior to it is another just touching the transverse band; beneath the second and third are two spots separated by the lower median 
nervule, that in the grey pale submerlian area being coutinned up to the base; transverse catenulated band composed of five spots from the third subcostal to the lower median mervule, the second of which is shifted inwards, the third well outwards, the fourth and tifth confluent well inwards, but with an outward inclination; subnuarginal row obscure; around the uppermost spot of the transverse band, the interior costal spot touching it, is a considerable greyish-white suffusion. Secondaries with a spot on the costal base, followed by two more touching each other; below the third ar three smaller basal spots, the lowest shifted on to the internal margin, then come three larger spots below each other; cell closed by a largish irregular spot, below which is a smaller triangular one; transterse band composed of eight spots, the upper two being round and separated from the others by a pale suffusion, the lower of these two is the smaller and shifted outwards; the fourth spot is shifted outwards, the fifth inwards, sixth outwards, seventh angular spot touching the eighth long one and shifted inwards; submarginal row obseure; a black spot at anal angle and between the second and lower median nervules, the space between and over which is filled with bronzy-greenish metallic scales, edged above by a dark suffusion. In the secondaries the spots near the costa are all very dark rich brown, the others quite pale; there is also more or less of a lilac suffusion in the basal half of both wings.

․ Upperside: both wings violet, with very broad brown costal and posterior margins to primaries and less broad borders to the secondaries. Underside as in male.

These descriptions appear to be of the commonest form of this species. Hewitson described his male (from Borneo) as brilliant morpho-blue, but his labelled type is violet-blue. I have specimens similar to this from Palawan, Miudoro, and Mindanao, and in all these the ground-colour beneath is darker, but the markings are the same. I have one female which might well answer to this male, as it is brilliant azure with very broad blackish borders. I have also three females in very good condition which are entirely brown, with no trace of blue whatever above. I am inclined to think that the species is dimorphic, as I have both forms from various islands of the Philippines (both forms from the same island), and I have also the violet-blue form from South-east and North-west Borneo now lying before me. This shows that both the morpho-blue and the violet-blue forms co-exist; it would therefore be most interesting to investigate the life-history of the species. The underside in both forms is precisely the same, except that the more brilliant of the two is darker on the underside. It is fortunately a well-marked species, so that there is no difficulty in recognising it. The figure given by Distant (Rhop. Malay. l.c.) as A. anthelus is without doubt annnda, and his text evidently partially refers to this species, he having, I imagine, not differentiated the two species. Dr. Staudinger has also described (vide Iris, l.c.) var. saturatior as a variety of anthelus; it is, however, a very bright and pale blue form of this species. The genitalia are somewhat similar to alce Hew., though the clasps differ, and the hooks are straight, whilst the penis is long, bent, and large at the orifice. 
Arhopala antharita Grose-Smith.

Arhopala antharita Grose-Smith, Novit. Zool. vol. i. p. 583 (1891); id. Rhop. Exot. part 44, Lye. no. 8, pl. xv. figs. $9 \& 10$, $q$ (1898).

Hab. New Guinea?

Expanse, ㅇ, $78 \mathrm{~mm}$.

I admit this species with donbt. It is described from a single specimen, and has, as Mr. Grose-Smith says, a very strong resemblance to anumla Hew., which species is decidedly variahle, even in its females, some of which are entirely brown on the upperside, as this species is. There being only one specimen extant, it is impossible to say more than this at present.

Arhopala axtuelus (Doubleday and Hewitson).

Amblypodia anthelus Doubleday and Hewitson, Gen. Diurn. Lep. vol. ii. p. 478. n. 5, pl. lxsiv. fig. 6, of (1852); Hewitson, Cat. Lycrenida B.M. p. 5. n. 22, pl. iii. figs. $23 \& 24$, + (1862). Satadra anthelus Moore, Journ. A. S. B. vol. iii. pt. 2, p. 38 (1884).

Narathura anthelus Distant, Rhop. Nalay. p. 263. n. 3.

Arhopala anthelus de Nieérille, Butt. Ind. vol. iii. p. 259. n. 818 (1830).

Hab. Moulmein ; Upper 'Tenasserim and ? Mergui.

Expanse, of 65-66, ㅇ 60-62 mm.

o. Upperside: both wings brilliant, lustrous, rather deep morpho-bine, deepening slightly on the outer clges; primaries with a rather narrow brown costa and wider black outer margin; secondaries with broad black costa, narrow outer margin, and a broadish patch of blackish at the anal angle. Lobe only moderately developed. Tail stout, long, black, tipped with white, the nervule on each side of which is slightly elongated so as to form a very short tooth. Underside: both wings very uniform, soft, rather pale ochreous brown, with spots, some very dark, and some with only an inner linear edging of dark brown, edged rather palely. Primaries with a heary dark donble spot at base of cell; a much larger treble coufluent spot in the middle, the two upper spots having paler central irrorations; cell closed by a very large distinct spot, above and below which is another one, the upper one having the greyish central scaling; all these spots are almost black; subdiscal area very dark brown; transverse band composed of six spots, the upper four palish with a double edging, the inner dark, the outer slightly paler than ground, the fifth and sixth almost black; the second spot is shifted well outwards, third rery slightly inwards, fourth (a darker spot than the previous ones) outwards but with an inward inclination, fifth spot large, shifted inwards, sixth very large, with an outward inclination; a trace of a submarginal very dark row. Secondaries with a rather dark narrow costal stripe; a blackish spot at the basal extremity of the costa, with another blackish spot beside it; four basal spots, the 
upper one largish, touching the second costal spot, the second and third very small and dark, the fourth rather larger, paler, and shifted inwards, followed by three spots, the upper one near the costa blackish, the second one in centre of cell, small, dark, with paler central scaling and shifted well inwards, the third larger, paler, with a good deal of paler scaling and shifted slightly outwards; cell closed by a large pale spot with a double edging, the inner one dark and onter one rather paler than the ground, below which is a smaller similar spot in the lower median angle; transverse band composed of eight spots, the first large, roundish, and black, with a little central paler scaling, second round, very small, dark, with paler centre, shifted outwards and quite isolated, third quadrate, shifted outwards, fourth right out but not detached, fifth well inwards, sixth well outwards, seventh angular, touching the long eighth spot, shifterl well inwards; all these last six spots are pale, with the double edging of dark and light; a trace of the submarginal row; lobe-spet blackish, small, and another small blackish spot on the other side of the tail, slightly edged above with greenish-bronze metallic scales, which also occupy sparingly the intermediate space.

i. Upperside: both wings lustrous silvery blue; primaries with a broad purplishbrown costa and onter margin increasing rapidly towards the apex, and with a large black cell-spot beyond the end of the upper part of the cell ; secondaries with a broad brown costa, narrow outer margin increasing very rapidly from the second median nervule to the anal angle, where it is very broad. Underside like that of the male.

There is generally in both sexes a light clouding, slightly mauvish, towards the end of the costa in the primaries, and below the subcostal nervule in the secondaries. This species is a very close ally of anunda Hew., and though the blue of the latter sometimes approaches it in shade (the type, however, being quite purplish), it is never so brilliant and morpho-like, and the black costa and outer margins are much narrower, being almost linear usually. The patterns beneath are almost the same, but the two species look quite distinct by the lack in anthelus of the white edging which is so very conspicuous a feature in anunla; the edging in the former is little paler than the ground-colour, the spots are also smaller in the secondaries, and the transverse band more irregular. Anumla is subject to considerable variation, both as to the tone of blue and as to the underside, which sometimes is very dark incleed, and the pattern is occasionally so enlarged as to become confluent over a large area of the wing. Anthelus, on the other hand, appears to be exceedingly constant in coloration; it is a very local species, but I imagine not excessively rare in its localities. The shape if the wings is likewise different, being somewhat excavated as to the outer margin of both primaries and secondaries, whilst in anunda they are very full and rounded, and the latter are decidedly more ample. 
Arhopala subfasciata (Moore).

Nilasera subfasciata Moore, Proc. Zool. Soc. Lond. 1883, p. 532, pl. xlix. fig. 2.

Arhopala subfasciata Doherty, Journ. A. S. B. vol. kriii.pt. 2, p. 418. 1. 5 (1889); de Nicéville,

Butt. Ind. vcl. iii. p. 260. n. 820 (1890).

Hab. Tavoy; 'Tenasserim Valley; Burma.

Expanse, ơ 44, q 48-49 mm.

This is a very beautiful species and should be distinguishable at a glance. It is, however, very close to ijanensis mihi, but is a much less robust insect, has a much larger blue area, and is very decidedly paler beneath; my species is more uniform in tone, and there is only a trace of the rery distinct white subcostal stripe so marked in Moore's species.

Arhopala ijauexsis Bethune-Baker. (Plate I. fig. 28, ơ .)

Arhopala ijanensis (recte ijauensis) Bethune-Baker, Ent. Mo. Mag. vol. xxxiii. p. 203 (1897).

Hub. Perak (Gimong Ijau).

Expanse, of \& $q, 48-50 \mathrm{~mm}$.

This fine species, in the Hon. Walter Rothschild's collection, is close to subfiscirta Noore, but decidedly larger ; the differences will be better gathered by reference to the figure.

Arhopala auxesia (Hewitson). (Plate III. fig. 23.)

Amblypodia auxesia Hewitson, Ill. Dium. Lep., Lyc. p. 5, pl. i, figs. 1 q, 2 \& 3 o (1865).

Hab. Sumatra; New Guinea.

Expanse $48-51 \mathrm{~mm}$.

This species is nearest anzea de Nicéville, but the upperside colour is quite different ; the distinctions are detailed in the description of that insect.

ARHOPALA FrUHSTORFERi Röber.

Amblypodia fruhstorferi Röbcr, Ent. Nach, vol. xxiii. p. 6 (1897).

Hab. Jara (Gede Mountain).

Expanse $43 \mathrm{~mm}$.

This species is described from a single female; unfortunately the description is decidedly inadequate, but, so far as I can judge, not haring seen the specimen, I believe it to be most probably auxesia Hew.

Arhopala adzea de Nicéville.

Arllopala auzea de Nicéville, Journ. Bomb. Nat. Hist. Soc. vol. x. p. 169. u. 19, pl. S. figs. 29 §, 30 ? (1896).

Hab. Java (Preanger). 
Expanse, \& f , 6t mm.

This species is nearest auxesia Hew., but the colour of the male is quite different, being somew hat silvery, shading into purplish at the borders, whereas aux sic Hew. is slightly greenish and rery metallic, with a white spot at the end of the cell, and very broad black costa and outer margin in the primaries. This species is paler in the female, with a dark spot closing the cell in the midst of a whitish patch, whereas Hewitson's species is purplish, darker in its male, and has no spot at the end of the cell. The underside pattern is likewise different, as described.

Arhopala axarte (Hewitson).

Amblypodia anarte Ilewitson, Cat. Lycænide B.M. p. 5. n. 20, pl. iii. figs. 16 \& $17, \delta$ (1862) ; Druce, Proe. Zool. Soc. Lond. 1873, p. 353. 11. 9; Doherty, Jourm. A. S. B. vol. lviii. pt. 2, p. 417 (1889).

Arhopala anarte de Nieérille, Butt. Ind. vol. iii. p. 260. n. 819 (1890).

Ilab. Myitta; Burma; Malacea (interior); Borneo; Makassar.

Expanse, o 61-69, ㅇ 65-68 $\mathrm{mm}$.

๑. Upperside: both wings brilliant pale morpho-blue, tinged with lilac; primaries with very narrow brown costa and outer margins; secondaries with broad brown costa and very narrow outer margins. Tail fine, long, tipped with white. Underside: both wings pale brown with a slight chestnut tinge, with darker spots palely encircled. l'rimaries with three increasing cell-spots, the second and third very large indeed, the second being the largest by its conflnence with two spots over it extending up to the costal nervure, and it is also joined to the third spot by an additional one along the upper margin of the cell; below the third spot is a large one in the lower median angle, generally connected with the third by a small intermediate spot; underneath the first and second, in the subdiscal area, is a very large spot half divided on the upper part of the centre; transverse band very unusual in form, divided into two distinct portions, the upper part forming a broad are of five increasing spots, beginning over the third cell-spot and extending to the submarginal row; the lower part is composed of two large ovate spots below each other, shifted so far inwards as nearly to touch the third cell-spot; submarginal row very indefinite and indistinct. Secondaries with a slight lilac suffusion in the upper half; at the extreme basal extremity of the costa are one or two spots, with four large basal spots below each other, second and fourth shifted inwards, followed by three larger spots below each other; cell closed by a very large irregular spot, below which is a small one in the lower median angle; transverse band composed of four pairs of spots, the second spet shifted outwards, the second pair is shifted right ontwards, the lower of which is the further out, the third pair well inwards, fourth pair inwards again, composed of the usual angular spot convected by a line or by a narrow neck with the long eighth spot; submarginal row fairly distinct, marginal row less so; a black velvety spot at the rol, xvil.-PaRt I. No. 11.-Angust, I903. 
anal lobe, which is slightly developed, preceded by two black spots, the middle one being almost entirely covered with pale bluish-metallic scales, and the other two broadly edged above in like mauner; the submedian nervule is elongated, so as to form a tootl making a second short inner tail.

ㅇ. Upperside: both wings pale lustrous violet-blue, more violet in hue at the outer edges; primaries with rather broad brown costa and broader brown outer margin; secondaries with broad brown costa and less broad brown outer margin, decreasing towards the anal angle. Underside just like that of the male, but without the lilac suffusion in the secondaries.

This is a very distinct species and may be at once recognised by its lustrous lilac-blue above, and by its distinct markings below, especially its transverse band. Mr. Mewitson confused this species with agnis Feld. (which latter he correctly figures on pl. i. figs. 6 \& 7 of 1ll. Dium. Lep.); he, however, tigures his own species fairly well in the first instance in the Cat. B. M. pl. iii. figs. $16 \& 17$, but the transverse band of the primaries is not quite accurate; the spots should be separate, and the two lowest spots forming the lower portion of the band are quite distinct and far scparated from the upler five; this, I believe, arises from the figure not being large enough, so that the markings are cramped to get them all in. There should, however, be no difficulty whatever in recognising at a glance this lovely insect.

Ariopala achelots (Hewitson).

Amblypodia achelous Hewitson, Cat. Lyc. B.M. p. 7. n. 30, pl. v. figs. 7, 8 o (1862); Druce, P. Z. S. Lond. 1873, p. 354. n. 13.

Norathura achelous Distant, Rhop. Malay. p. 2i1. n. 18, woodeut n. 8:2, o (1885).

drikopala achelous de Nicéville, Butt. Ind. vol. iii. p. 22:\$ (1890); Druce, P. Z. S. Loud. 1895, p. 590 .

Ilab. Singapore; Borneo.

Expanse, of \& ㅇ, $46 \mathrm{~mm}$.

This species is very marked and should be recognised without difficulty, the spots beneath are very dark and prominent and the pale purplish subcostal stripe is a marked character.

Arhopala havilandi Bethume-Baker.

Arlopala havilandi Bethunc-Baker \& Druce, P. Z. S. Lond. 1s96, p. 665, pl. xxx. figs. 8 o , 9 q.

IIab. Kina Balu; Borneo.

Expanse, of o, $47-48 \mathrm{~mm}$.

I originally compared this species with aidt de Nicéville, but having more recently seen a larger series of achelous Hewitson, I have no doubt the present is its proper place: it may be easily separated by the deeper purplish blue of the upperside, and by the quite uniform tone of the underside; it entirely lacks the pale subcostal streak 
of the sccondaries as well as the large dark spots which are so prominent in Hewitson's species.

Arilopala afabi (Ilewitson).

Amblypodia agaba Hewitson, Cat. Lycenide B.M. p. 8. 11. 39, pl. iv. figs, 39 \& 10, f (1869).

Sutadra aguba Moore, Journ. A. S. B. vol. liii. pt. 22, p. 38 (1856); Elwes and de Nicéville, Jouru. A. S. 13. vol. lv. pt. 2, p. 430. n. I04. (Is8(i).

Arlanpelte agaba de Nicéville, Butt. Ind. vol. iii. p. 241. n. 797 (1890); Doherty, Journ. A. S. B. vol. tviii. pt. 2, p. 4:2. n. 20 (1889).

Ihub. India; Mergui Archipelago; Upper Tenasserim; Tavoy.

lixpanse, d \& \& , $41-47 \mathrm{~mm}$.

§. Upperside: both wings bluish purple; primaries with the costa having a very fine linear black line and a narrow black onter margin; secondaries with a broad blackish costa and narrow black outer margin; abdominal fold grey; tail long, black, tipped with white. Underside: both wings brown tinged with purple, with a superimposed strong lilac gloss, with darker spots margined with very pale lilac. Primaries with the lilac gloss contined to the costal half of the wing; three increasing spots in the cell, above the third spot a small one close to the costa, below it (the third spot) it larger one; snbdiscal area dark; transverse baud oblique, outwardly almost straight, but occasionally slightly bent at or below the fourth spot, the band being componct of seven spots, not quite evenly pliced, but in the main in a fairly straight direction; submarginal row distinct, submedian area pile yellowish grey. Secondaries with the lilac gloss more or less all over, but strongest near the base and at the apex; four basal spots, the third shifted slightly outwards and the fourth well inwards, follower hy three larger spots below each other; cell closed by a subquadrate spot, below which is a small one connecting it with the lowest of the three jnst mentioned, the spot closing the cell also touching the trunsverse band giving it a bifurcated appeuance; transverse band composed of eight spots, the first two below each other and large, the third shifted well outwards, fourth further out, fifth slightly inwards, sixth outwards, seventh angular spot well inwards, eighth long spot outwards but inclined upwards to the internal nervure; submarginal band distinct, largish, somewhat indefinite, o black spot on the small anal lobe, beyond which a few greenish-metallic scales are sprinkled.

우. Upperside: both wings bright ultramarine-blue, tinged with purple in certain lights; primaries with costa broadly, outer margin more broadly, aud apical area still more broadly black; secondaries with very broal margins all round, but decreasing towards the anal angle. Uuderside like that of the male, but often with much less of the lilac glossing.

This is probably a somewhat local species, though not rare in its own localities. From havilandi it may be at once separated by its decidedly smaller size and its much 
duller and purpler and non-lustrous blue, whilst below the pattern is quite different. It is rare in European collections, and as the male has never been figured, 1 have thought it well to do so now.

Arhopala SELta (Hewitson).

Amb7ypodia selta Hewitson, Ill. Diurn. Lep., Lyc. p. 14. n. 92, pl, iii $a$. figs. 36 \& 37 (1869).

Satadra selta Moore, J. A. S. B. vol. liii. pt. 2, p. 38 (1881).

Arhopala selta de Nicérille, Butt. Ind. vol. iii. p. 245. n. 798 (1890).

Ilab. Moulmcin; Mergui; Tenasserim.

Expanse, of, $38 \mathrm{~mm}$.

This species is not unlike a small specimen of agaba Hewitson, but it lacks the strong purplish tint of the underside, which is replaced by a much more subdued pink, and the pale lilac washing is totally absent; in the secondaries also the transrerse band is quite disconnected from the upper two spots and is shifted well out from them and the spot closing the cell. Agaba is also a decidedly larger insect and is more purple and duller in tone, whilst the black margins are much narrower, especially in the secondaries.

In de Nicéville's collection are several specimens from Tenasserim, and one female in which the blue is bright lustrous cobalt.

Arhotala brooket, n. sp. (Plate I. fig. 29, o.)

1lab. Pulo Laut; Borneo.

Expanse, ơ, 40-44 mm.

§. Upperside: both wings very deep indigo-purple, nearly as dark as in bazalus Hew. ; primaries with a very fine black costa and the finest black linear onter margins; secondaries with broad brown costa and fine blackish outer margins; tail fiue, whitetipped; abdominal fold brownish grey. Underside: both wings dull brown with slightly darker markings, faintly and palely encircled. Primaries with all the markings very obscure, three small increasing cell-spots, below the third a smaller one in the lower median angle; transverse band composed of five spots, the first threc outwardly oblique, the fourth shifted inwards, below which is the fifth, shifted outwards; submarginal row indistinct; submedian area paler. Secondaries with an indistinet spot at the basal extremity of the costa, four basal spots below each other, the third shifted outwards, followed by three larger spots below each other; cell closed by a subquadrate spot, below which is a small spot in the lower median angle; transverse band composed of eight spots, the second one much larger than the first and touching the spot closing the cell, third shifted right outwards and detached, fourth outwards again but with an inclination inwards, fifth inwards, sixth outwards, seventh angular spot right inwards and detached, and practically confluent with the long eighth spot; submarginal row rather indistinct, darker over the pale sky-blue metallic scaling at anal angle. 
I have before me one specimen from Pulo Laut in which the brown surface below is quite lustrous and the markings of the primaries are much more distinct.

This species is nearest aroc Ilew., but can be recognised immediately by the exceptionally dark blue of the upper surface, in which it differs from all its near allies.

Arhopala scera, n. sp.

Hab. Sumatra.

Expanse, of \& $q, 40 \mathrm{~mm}$.

3. Upperside: both wings purple of a reddish tint, in a side light having a brownish shade; primaries with a narrow brown costa and outer margin; secondaries with a broad brown costa and narrow onter margin; the lower median nervule is elongated into a distinct tooth, but apparently there is no tail. Underside: both wings warm greyish brown with darker spots palely encircled. Primaries with three increasing cell-spots; below the second and third are two smaller ones divided by the lower median nervule; transverse band composed of six spots with a detached one below the sixth in the submedian area; first spot small and round, second, third, and fourth each shifted beyoud its predecessor and increasing in size, of a broadish oval shape, fifth spot of same shape shifted inwards, sixth inclined slightly outwards, and below this the seventh detached spot already referred to; submarginal row very obscure. Secondaries with four basal spots, second and fourth shifted slightly inwards, followed by three large spots below exch other, of which the second and third touch ; cell closed by a largish spot, below which is a very small one in the lower median augle; transierse band compersed of eight spots, the second shifted well outwards, third and fourth confluent, shifted well outwards again, fifth narrow, wedgeshaped, shifted inwards, sixth outwards, seventh and eighth confluent and shifted right inwards; submarginal row less obscure than in the primaries; anal spot deep black, preceded by two others, more or less covered with metallic bluish or greenish scales.

ᄋ. Upperside: both wings violet; primaries with broad brown costa, broader outer margin, and yet broader apical area; secondaries with very broad margins all round. Underside as in male.

This species has a very distinct underside; the spots are prominent and the transverse binds have an unusual look difficult to describe, especially in the primaries, in which the spots are of a broad flattened oval shape.

Ariopala aro. (Hewitson). (Plate V. figs. 3 \& 3 a.)

Amblypodia aroa Hewitson, Ill. Dimm. Lep., Lyc. p. 13. n. 60, pl, ii. fig. 12, (1862); Butler,

Trans. Linn. Soc. Lond., ser, 2, Zool. vol, i. p. 548 (18\% $\%$ ). Nirathura aroe Distant, Rhop. Malay. p. 266, pl. xxiii. fig. 17, o (1855). Arhopalı aroa de Nicérille, Butt. India, vol. iii. p. 214 (1890). 
Amblypodia pryeri Butler, P. Z. S. Lond. 1892, P. 121.

Arlopela aroa and pryeri Druce, P. Z. S. Lond. 1895, p. 590.

Arhopalc aroa de Nieéville and Martin, J. A. S. B. vol. lxiv. pt. 2, p. 465. n. 394 (1895).

Hab. Sumatra; Malacca ; Jara; Burma; Penang; Singapore; Borreo; Batchian; and New Guinea.

Expanse, \& \& \& , 42-47 mm.

This species is easily separated from selta by the plain brown underside, also by its larger size and narrow black margins above. It is an insect of very wide range and raries somewhat in tone of colour both abore and below, the blue sometimes being quite blue and sometimes purplish; the underside markings are very constant. It comes within de Nicéville's Indian region; I have specimens from Burma and from Tenasserim. In Sumatra it is common, and I have it also from Java, Malacea, Singapore, Batchian, Borneo, and New Guinea. The genitalia are of the ordinary pattern, the hooks being slencler, but the clasps robust, whilst the penis has a sonsewhat peculiarly shaped orifice, as will be seen from the figure (Pl. V. fig. $3 a$ ).

Ariforala elopura 1)ruee. (Plate V. figs. 4 \& $4 a$.)

Arhopala elopura Druee, Ent. Mo. Mag. scr. 2, vol. v. 1. 9 (1894) ; id. P. Z. S. Lond. 1s\%5, p. 590, et 1896 , p. $6 \% 0$, pl. xxix. fig. 6 .

Hab. Borneo.

Expanse, o \& ㅇ, $39-42 \mathrm{~mm}$.

This is evidently one of the commonest species of the genus in Borneo. I have specimens before me taken in every month from Narch to September inclusive. It is nearest to aroa Hewitson, but may be recognised by its more purple colour above, and easily by its pale underside, by the markings being no darker than the groundcolour, and by the transverse band of the primaries being always dislocated at the fourth spot. The genitalia are peculiar, the hooks being broadly spatulate, with an ample hooded tegumen and heary clasps; the orifice of the penis has a peculiar projecting upper lip, as shown in the figure.

Arhopala rafflesil de Nicéville.

Narathura am, hinuta Distant (nee Felder), Rhop. Malay. p. 26z. n. 2, pl. xxi. figs. 9 o , 10 o (1885).

Arliopella rafflesii de Nicéville, Butt. India, vol. iii. p. 218. n. 803, pll. frontispicce fig. 136.

Arhopole pseudomuta de Nić́ville and Martin, J. A. S. B. vol. lxiv. pt. 2, p. 46.5 (1895).

Ilab. Burma; Penang, Province Wellesley; Singapore; Sumatra; Mergui.

Expranse, of 43 , ㅇ 40-41 mm.

This species is nearest pseudomuta Staudinger, but can be recognised at once by its mnch brighter, lighter, and bluer colour, and by the very decidedly broader borders of the upperside, and beneath by the difference in the transverse bands of both wings; in the primaries the fourth spot is always shifted well out and dislocated (not so in 
pseudomita), whilst in the secondaries the whole band is different. In Standinger's species spots 1 and 2 are quite isolited, and 3,4 , and 5 form an even arc, whilst in inffesii 1 and 2 are confluent and almost quadrate, and 3 to 6 are nearly straight; the latter is also a smaller insect. De Nicéville and Martin $(l . c$. $)$ sink this species under pseulomuta staudinger, but they are quite distinct.

Arhopala psel doneta (Staudinger). (Plate I. fig. 30, 8.)

Amblypodia psendomute standinger, 1ris, vol. ii. p. 195 (1889).

Arhopula pseudomuta Bethume-Baker and Druce, P. Z. S. Lond. 1896, p. 662.

Ilull. Malacea; Borneo.

Expanse, \& 46 , of $47 \mathrm{~mm}$.

This species may be recognised from raflesii de Nicéville by its larger size and blaer chlour; more detailed differences are given in the description of that insect.

Ariofala atosil (Hewitson). (Plate V. figs. 5 \& 5 a.)

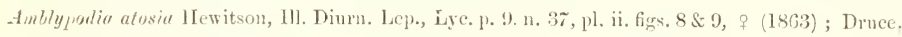

P. Z. S. Lond. 15:3, p. 353. n. 4; Butler, Trans. Limn. Soc. Lond., ser. 2, Zool. vol. i. p. 518.

n. 5 (18i

Narethura atosice Distant, Rhop. Malay. p. 265. n. 7, pl. xxiii. figs. 5 \& , 6 ठ (1895).

Arhopalu utusin de Nicéville, Butt. Ind. vol. iii. p. 211, frontispiece fig. 135, $\delta$ (1890); Druce, P. Z. S. Lond. 1895, p. 589.

Aihopala atosia de Nicérille, J. A. S. B. vol, lxiv. pt. 2, p. 165 (1895).

Amblypodia aricia Staudinger, Iris, vol. ii. 1. 124, Taf. i. fig. 15 (Is89).

Ilab. Sumatra; Borneo; Malacca; Mergui; Tenasserim Valley; Burma; Penang; Sapranaya; Pulawan.

Expanse, of \& 우, $39-45 \mathrm{~mm}$.

§. Upperside : both wings violaceous blue, with a linear black costa and posterior margin to primaries, and a large patch of differently arranged scales in the centre of the wing, showing darkly through in certain lights, but not altering the colour of the wing; a broad costa to secondaries and a linear black posterior margin; abdominal fold greyish; tail black, tipped with white. Underside: both wings greyish brown with scarcely darker spots palely encircled. Primaries with three increasing discoidal spots; beneath the second and third are two spots in the submedian area and in the lower median angle respectively; above the third spot is often a small one near the costa; transverse band consisting of four confluent spots outwardly inclined, the fourth shifted further out than the others, followed by two confluent spots shifted right inwarls; submarginal row just traceable. Secondaries with fiur basal spots inclined inwardly, but the third spot is projected outwards, followed by three rather larger spots below each other; cell closed by a subquidrate spot, below which is it small one in the lower median angle; transverse chain-band compoied of two upper spots touching each other, detached from rest of band, the third and fourth spots are each shifted outwards, fifth inwards, its inner margin being far inwards, sixth very 
slightly outwards, the seventh angular spot well inwards and confluent with the long eighth spot; submarginal row just traceable; a black spot at anal angle and between the submedian and lower median nervules, over which are scatterert thickly bright metallic-blue scales which extend beyond the lower median nervule; over these metallic scales there is a dark edging, extending up to the internal nervure.

․ Upperside: both wings pale violet; primaries with broadish blackish costa to near end of cell, where it increases suddenly into the exceedingly broad apical area; outer margin rery broad; secondaries with broad dark costa and decidedly less broad outer margin.

I have before me three distinct forms of the female, viz. :- the type; another form from Penang, in which the colour is bright deep lustrous blue, not violet at all, with quite typical males; and a third form from Tenasserim, in which the colour is pale lustrous silvery blue, but here many of the males are paler, bluer, somewhat silvery, and more lustrous, approaching near to the colour of pastorella Doherty. The underside pattern of each is just the same, like the typical males. The species can only be separated from cpimuta by the presence of tails. 'The violet colour of the upper surface distinguishes the males from any close allies, and also the pattern beneath, especially the dislocated transverse band.

Staudinger's species aricia is identical with the pale silvery-blue form from Burma, showing the darker patch of scales, but less distinctly. The genitalia also help to scparate this species from eyimuto, the clasps being less broad at the base and rounder at the extremities; the hooks in both are broadish and inclined to be spatulate, not tapering narrower as is often the case (see Pl. V. fig. 5).

Anhorala epimuta Moore (nec Hewitson). (Plate II. fig. 9, ơ; Plate V. fig». 6 \& 6 a.)

Amblypodia epimuta Moore, Cat. Lep. E.I.C. p. 42 (185\%).

Arhopala epimuta Druce, P. Z. S. Lond. 1895, p. 593.

Arhopala antimuta de Nicéville, Butt. India, vol. iii. p. $2 \pi$ (1890).

Arhopala antimuta de Nicéville and Martin, J. A. S. 3. vol. lxiv. pt. 2, p. 469 (1895).

Arhopala epimuta Druce, P. Z. S. 1895, p. 593.

Hab. Borneo Straits; Perak; Penang; Mergui; Tenasserim.

Expanse, of \& o , 44-46 mm.

The species is an exceedingly close ally of atosia Hew. : in fact, almost the only character by which they can be separated is that Hewitson's species has tails and this has none. This is the insect that de Nicćville identified as antimuta Feld., the type of which I have carefully examined, and I find that davisonii de $\mathrm{N}$. is the antimuta of Felder. It will be observed that it has an exactly similar distribution as atosia Hew. I have specimens before me from each of the same localities. The genitalia of this species are referred to in the description of A. atosia Hew.; in both the penis is 
peculiar, being strongly curred near the centre, whilst the orifice is somewhat trumpetshaped, but with a strongly projecting upper lip, which is best shown in the figure of the previous species (Pl. V. fig. $5 a$ ).

Arhopala moolataia (Moore). (Plate II. fig. 6, o .)

Narathura moolaiana Moore, P. Z. S. Lond. 18\% \%, p. 835.

Amblypodia epimuta Hewitson (nec Moore), Cat. Lycenidæ B.M. p. 11. n. 51, pl. vi. figs. 59 \& 60 , \& (1862).

Arhopala pastorella Doherty, J. A. S. B. vol. Iriii. pt. 2, p. 418, pl. xxiii. fig. 12 (1889); de Nicéville, Butt. Ind, vol, iii. p. $2 \pi+(1890)$.

Arhopala moolaiana de Nicérille, Butt. Ind. vol. iii. p. 27t (1890).

Arhopala agelastus de Nicérille, Butt. Ind. vol. iii. p. 278 (1890).

Narathura agelastus Moore, Journ. Limn. Soc. Loud., Zool. vol, xxi. p. $44(1886)$ ?

Hab. Burma; India ; Tenasserim; Mergui; Penang; Perak; Bheeling.

Expanse, ㅇ $47-52$, 우 $47-50 \mathrm{~mm}$.

đ. Upperside: both wings morpho-blue, shading towards the outer margins into darker slightly purplish blue; primaries with a narrow blackish costa and outer margiu; secondaries with a not very broad brown costa and narrow outer margin. Inderside: both wings ochreous brown with darker spots palely encircled. Primaries with three increasing cell-spots, first and second rather small. third subquadrate, below the two last are two other spots separated by the lower median nervule; transverse band composed of six spots, the first four almost conflnent and with an outward oblique inclination, forming a very slight arc, the first spot on the costa quite small, fitth spot shifted inwards, below which is the sixth: submarginal row distinct; marginal row barely discernible; submedian area pale; subdiscal area with a purplish-brown tinge. Siecondaries with four small basal spots below each other; second and fourth shifted slightly inwards, followed by three large spots below each other, the middle one shifted slightly inwards; cell closed by a slightly reniform spot, below which is a small one in the lower median angle; transrerse band composed of eight rather distinct spots, the second shifted right out, just touching the outer edge of the first, third shifted right outwards again, touching the fourth below it, fifth shifted well inwards, sixth outwards, serenth angular spot right inwards, not discomected, touching the irregular-shaped eighth spot; submarginal row distinct, marginal row less distinct, a blackish spot at the anal angle preceded by two other's which are almost hidden by the superimposed pale greenish-metallic scales, the spot at the angle having a broadish upper edging of these scales.

ㅇ. Upperside: both wings pale morpho-blne, darker at the edges; primaries with broad black costa, increasing towards the apex, and very broad outer margin; the black apical area is extensive; secondaries with a very broad blackish costa and narrow onter margins. Underside as in male.

VOL. XII.-PART I. No. 12.-Aingust, 1903. 
In a male specimen from Perak the blue has a violet tinge, but is almost as lustrous as in the usual form.

De Nicéville $(l . c$. ) has referred to this species under the name agelastus Hew. In his fine collection of this group, which he has so kindly lent me, is a large series of this species, the females preponderating by two to one male, taken mainly in Burma and Tenasserim, but there are specimens also from Mergui, Penang, and Bheeling. I have no doubt, from the single example of Doherty's species pastorella before me, and from his figure of it, that this is identical with moolaiana.

Arhopala amphimuta (Felder). (Plate II. fig. 7, 0.)

Amblypodia amphimuta Felder, Wien. ent. Monatsch. iv. p. 396 (1860).

Arhopala amphimuta Felder, Reise Novara, Lep. vol. ii. p. 232, tab. xxix. fig. 8 (1865).

Arrhopala amphimuta de Nicéville and Martin, J. A. S. B. vol, lxiv. pt. 2, p. 469 (1895)?

Arhopala amphimuta Druce, P. Z. S. 1895, p. 592.

Hab. Malacca.

Expanse, ơ, $50 \mathrm{~mm}$.

o. Upperside: both wings soft violet, with a brownish shade in side-lights; primaries with costa and outer margin very narrowly brown; secondaries with broad brown costa and very narrow outer margins. Underside clear ochreous brown with slightly darker spots palely encircled. Primaries with three increasing cell-spots, below the third a small one in the lower median angle; transverse catenulated band composed of six spots fractured below the fourth, the upper four have a slight outward inclination, almost a curve, the first spot on the costa being very small, the fifth is shifted well inwards, and the sixth slightly inwards also; there is the least trace of a submarginal row ; the submedian area is slightly paler than the ground-colour. Secondaries with four basal spots below each other, the second and fourth shifted slightly inwarls, followed by three larger spots with a slight inward inclination; cell closed by a subovate spot, below which is a small one in the lower median angle; transverse catenulated band composed of eight spots in pairs, the first two quite separated and distinct, the lower of which is shifted well outwards, the third and fourth confluent, shifted well outwards, fifth and sixth confluent, shifted inwards, seventh angular spot confluent with the eighth and shifted again inwards; submarginal row distinct, marginal row less distinct; at the anal angle is a very large blackish spot extending into the next nervule space and well covered with a bright pale blue metallic spot, of which there is a slight trace in the second median nervule space.

This species can at once be separated from moolaiana Moore by the violet colour of the upperside, which in Moore's insect is almost morpho-blue; the underside is also somewhat different as described. From inornata Feld., a still closer ally, it is more difficult to separate; it has, however, a much duller upper surface and is not so blue, whilst beneath the pattern is much more distinct and both transverse bands are more 
dislocated. Both Mr. Butler and Mr. de Nicéville are right in considering this species distinct from hypomnta Hew. It is quite distinct. I have examined the type of each most carefully and have no hesitation in saying that they are so distinct that probably both Mr. Hewitson, and certainly Mr. Distant, wrongly identified Felder's species. I am led to this conclusion from Mr. Distant's figures, which do not resemble the species in either shape, colour, or patteru. It is quite different in shape from hypomuta, its costa beiug very strongly arched and the wing very much broader in the primaries; in the secondaries the outline is more angular, hypomuta having the outer margin a very even curve, it (amphimuta) is also half as large again and the underside pattern will be seen, on reference to my figures, to be also different. Amphimuta appears to be an exceedingly rare species, and as yet I have not seen a female of it.

Arhopala inoriata (Felder). (Plate II. fig. 8, 8*.)

Amblypodia inornata Felder, Wieu. ent. Monatsch. vol.iv. p. 396 (1860): Hewitson, Cat. Lycenida B.I. p. 1: (1 $\$ 62)$.

Arhopala inornata Felder, Reise Novara, Lep, vol. ii. p. 234, pl, xxix. tig. 12, ơ (1865)

Narathera inornata Distant, Rhop. Malay. p. 271, woodeut n. $81, \delta$ (1885).

Hab. Malacca, interior; Philippine Islands.

Expanse, of 49, \& 49-50 mm.

§. Upperside: both wings rather bright violet-purple, with the linear brown costa and onter margin in the primaries; secondaries with a broadish brown costa and linear outer margin. Underside: both wings greyish brown, with slightly darker markings palely encircled. Primaries with all the pattern very obscme, with three increasing cell-spots, below the second and third are two almost obsolete spots divided by the lower median nervule; transverse band composed of five spots, beginning below the upper discoidal nervule, the first three confluent, with an outward inclination, the third spot being angled on its interior edge and so made almost confluent with the fourth and fifth, which are directly below each other and shifted slightly inwards; submedian area slightly paler than the ground-colour. Secondaries with pattern plainer than in primaries, with four small cramped spots very near the base of wings, followed by three decidedly larger ones below each other; cell closed by a reniform spot, below which is a small one in the lower median angle; transverse band composed of eight spots, the secoud being very much larger and directly below the first, the third and fourth confluent, shifted right out on to the outer edge of the second, fifth and sixth confluent with the fourth, but with their inner edges only shifted slightly inwards, serenth angular spot shifted right inwards, disconnected, but confluent with the eighth long spot; submarginal row represented by a band of dark shading.

․ Upperside: both wings pale violet, with a broad brown costa and outer margins increasing towards the apex, which is largely brown in the primaries. In the 
secondaries the costa is broadly brown and the outer margin narrowly browu, increasing slightly close to the anal angle. The underside is exactly like that of the male, but rather paler and with the pattern rather plainer. This description is taken from Felder's types from the Malacca interior, which the Hon. Walter Rothschild has kindly placed at my disposal.

The species is very distinct and easily recognisable. I have, however, a specimen from Perak in which the blue is very much more extensive and is of a lustrous azureblue with a violet tinge; the underside is of exactly the same tone and pattern. 'This species is very near amphimuta Feld, ; it is, however, decidedly brighter and purpler, and its dark margins are but linear, whilst on the underside the pattern is very obscure, the transverse band of the primaries is not fractured, and the same band in the secondaries is different, the four middle spots being practically confluent; it has also no dark spots or metallic scaling at all at the anal angle.

The species is evidently very rare: I have only seen three specimens, viz. the types from Malacca interior and a female from Perak.

Arhopala asia de Nicéville.

Arhopala asia de Nicéville, Journ. Bomlsay Nat. Hist. Soc. vol. vii. p. 333. n. 9, pl. H. fig. 16, ठ (1892) ; id. Journ. A. S. B. vol. lxiv. pt. 2, p. 470. n. 426 (1895).

Hab. Quang, Malay Peninsula; Sumatra, Borneo, and Malacca.

Expanse, of \& $q, 48-50 \mathrm{~mm}$.

I possess specimens of this species from Labuan, where Waterstradt obtained it in the year 1893 (I believe). The late Dr. Staudinger's collection also has specimens from Borneo. All these are somewhat bluer and darker than the type, though evidently the same species. I notice also that de Nicéville's Sumatra specimens are darker than his type from the Malay Peninsula. It is not difficult to separate them from inornata Feld., as its wings are broader and the secondaries decidedly more ample and the brown margins rather wider. Beneath it is more easily separated, as the pattern is much plainer and is very distinctly spotted, whereas in inornata the spots are much more confluent; this latter feature, of course, mainly refers to the transverse band.

It is, I imagine, not very rare where it occurs; 1 have a fair series before me from Borneo.

The genitalia are very similar to those of $A$. catori, but are decidedly larger.

ARHopala kURzi (Distant).

Narathura kurzi Distant, Rhop. Malay. p. 682. no. 12, pl, xxi. fig. 1, ơ (1885).

Arhopala kurzi de Nicéville, Butt. Ind. vol, iii. p. 278 (1890).

Hab. Malacca; Penang.

Expanse, ơ, $44 \mathrm{~mm}$.

'This is a smaller and slighter insect than asia of de Nicéville, and the colour above 
is decidedly different. On the nuderside the transverse band of the primaries will at once separate it, and the same band in the secondaries is also very different. I have only seen one specimen, kindly sent by de Nicéville.

Arhopala agesilaus (standinger). (Plate II. fig. 10, o; Plate V. figs, $7 \& 7 \pi$.)

Amblypodia agesilaus Staudinger, Iris, rol. ii. p. 12i, Taf. i. fig. 16 (non 17) (1889).

Arrhopala agesilaus de Nicéville and Martin, J. A. S. B. vol. Kxiv. pt. 2, p. 465 (1895).

Hab. Palawan; Sumatra; Mindanao; Borneo; Perak; Malacca.

Expanse, ot 44-45, \& 39-43 mm.

This species may be separated from asia de $\mathrm{N}$. by its much smaller size, the very broad borders to its wings, and by its bluer and paler upper surface. From kurzi Distant it may be separated by the difference in colour and by the rery broad borders of the upperside, and beneath by the very different transverse band. It appears to be widely spread throughout the Malay Islauds. I have many specimens before me from Palawan, and it also occurs in other islands of the Philippine group. I have examples also from Nias, Borneo (where it is not uncommon), Perak, and Sumatra, where the colour of the upperside is decidedly brighter blue.

staudinger suggested that the name v-major might be given to a larger insect which is paler beneath and also above; but this specimen from sumatra does not belong to this species at all; and though the Bornean specimens are decidedly larger than those from most other localities, there is no other difference, and as it was not described the name may be allowed to drop.

The genitalia are unusually small, the hooks have an upward inclination, and the penis is straight, with a trumpet-shaped orifice, as is shown in figure $7 a$, Plate V.

Arhopala catori, n. sp. (Plate II. tig. 11, o; Plate V. tigs. S \& S a.)

Hab. Bonneo; Bilit; Palawan.

Expanse, o 44-46, \& 42-44 mm.

c. Upperside: both wings dark purplish sublustrous blue, in a side light the tone being very deep; primaries with costa dark brown of medium width, outer margin rery broad, wider towards the apex; secondaries with very wide margins all round. Underside: both wings warm ochreous brown (occasionally sub-olivaceons), with rather darker spots palely encircled. Primaries with three rather small increasing cell-spots, below the third an indistinct one ; transverse band composed of five spots (very occasionally six by the addition of a small and very indistinct one just below the costa), the first (on the third subcostal nervule), second, and third almost confluent, with an oblique outward inclination, fourth and fifth shifted well inwards but having an oblique outward inclination; submarginal row obscure; submedian area very slightly paler than the ground. Secondaries with four very small basal spots, the third shifted outwards, il rather larger spot in the centre of the cell, below which is a larger one; cell closed by 
a subovate spot, below which is a very small indistinct one in the lower median angle; transverse band composed of eight spots, the first and second isolated, second shifted outwards, third and fourth shifted right outwards, fifth narrow inwards, sixth outwards, seventh right inwards and confluent with a long eighth spot; submarginal row fairly distinct, edged inwardly with a light border; a black spot at the anal angle preceded by a blackish patch almost entirely covered with bright azure-blue metallic scaling which edges the anal spot broadly above.

․ Upperside: both wings paler violet-blue; primaries with broad brown costa and very broad outer margin, each increasing towards the apex; secondaries with very broad brown margins all round. Underside just like that of the male, but rather paler.

This species is near agesilaus Stdr., but has rather broader borders above, whilst beneath it is at once recognizable from any of its near allies by the complete absence of any spot just below the costa between the upper basal and the first spot of the transverse band of the secondaries. This is quite a remarkable character. The spots are all smaller and more obscure.

I have sixteen specimens before me from Borneo and Bilit (a small island off the mainland), and one from Palawan. I dedicate the species to $\mathrm{Mr}$. Cator, who has brought home a good many examples of the genus and has kindly placed them at my disposal. I received it, however, in single specimens from other entomologists, but Mr. Cator brought the majority.

The genitalia have an ample hooded tegumen with moderately strong hooks that are inclined downwards, the clasps are conical at their extremities; the penis of moderate length, but not quite straight, as shown in figures $8 \& s a$ of Plate $V$.

\section{Arhopala similis Druce.}

Arhopala similis Drucc, Proc. Zool. Soc. Lond. 1895, p. 592.

Arhopala anila de Nicéville, J. A. S. B. vol. lxiv. pt. 2, p. 469 (1895).

Arrhopala anila de Nicéville, Jourı. Bomb. Nat. Hist. Soc, vol. x. p. 6 (1896).

Hab. Sandakan; Sumatra; Salangor.

Expanse, of 42-43, ㅇ 44-45 mm.

7. Upperside : both wings bright blue with a violet tinge; primaries with a broad blackish costa and posterior margin, each of which increases rapidly towards the apex, so that the apical area is as wide as in the female of most species of the group ; secondaries with broad margins all round, the costa being broadest. Underside as in agesias Hewitson, except that there is no transverse band at all in the primaries.

․ Just like the male, except that the blue of the upperside is less violet in tinge. There is no difference in the extent of blue in males and females. The species is very close to agesias, but may be recognised by the absence of the trausverse band in the primaries. Dr. Martin obtained it in fair numbers in Sumatra. 
Arhopala agesias (Hewitson). (Plate III. fig. 27 ; Plate V. figs. 9 \& 9 a.)

Amblypodia agesias Hewitson, Cat. Lyc. B.MI. p. 2. n. 49, pl. vi. figs. $55 \& 56$ (1862).

Amblypodia ovomaculata id. Ill. Diurn. Lep., Suppl. p. 22. no. 103, pl. suppl. viii. figs. 66 \& 67 (18\%8).

Arhopala agesias de Nicéville, Butt. Ind. vol. iii. p. 273 ; Druce, Proc. Zool. Soc. Lond. 1895, p. 592. Arrhopula agesias de Nicéville and Martin, J. A. S. B. vol. lxiv. pt. 2, p. 469 (1895).

Hab. Borneo; Malacca; Sumatra; Pulo Laut.

Expanse, of \& ㅇ, $39-43 \mathrm{~mm}$.

This species is subject to considerable variation as to the size and colour of the spots beneath; in Hewitson's type these are small and dull, whilst in others they are very large and very dark, and the metallic scaling is often much extended towards the costa and differs in colour. I have a specimen from Kina Balu before me in which the colour is brilliant golden bronze, others are bright blue or green; the blue is also subject to variation, some being quite violet, others much bluer, whilst in the Kina Balu specimen the blue is brilliant azure. Hewitson describes a female in which the transverse band is absent; this has been named similis by Druce and anila by de Nicéville.

The male of this species appears to have been mistaken for the female, as both sexes are precisely the same. I have mounted the clasping-organs of one male, and have betore me other specimens which I believe to be of the same sex. As I have specimens from sumatra, Borneo, and Pulo Lant (a small island off New Guinea), it is not improbable that it may be more widely distributed over these islands than is yet recorded.

The genitalia are peculiar ; the tegumen small with extremely broad clasps, the clasps are long, with a wared outline, and the penis is bent a quarter from the orifice (see figs. : \& 9 a, Plate V.).

1. ocomeculata I cannot regard as anything but a very handsome, darkly and very largely marked form of this species; the pattern is exactly the same, there being no difference whatever above or below, except that all the spots are very greatly exaggerated in the secondaries, as also is the metallic anal scaling. I have figured this form on Plate III. fig. 27.

Arhopala hesba (Hewitson). (Plate III. fig. 28, o .)

Amblypodia hesba Hewitson, Ill. Diurn. Lep., Lyc. p. 142, pl. iii $b$. fig. 47 (1865)

Ifal. Philippine Islands.

Expanse, of \& 오, 39- $\$ 0 \mathrm{~mm}$.

1 rery distinct and easily recognisable species; the brilliant morpho-blue of the upperside and the decided set pattern and warm chestnut-brown of the underside give it quite a marked individuality of its own. It has hitherto been recorded from the Philippine 1slands only. 
Arhopala dataona Semper. (Plate II. fig. 12, ơ.)

Arhopala davaona Semper, Schmett. Philip. Ins. Band v. p. 204.

Hab. Mindanao.

Expanse, of \& \& , $37 \mathrm{~mm}$.

$0^{*}$. Upperside : both wings exceedingly deep purplish indigo-blue, with a dead lustre in certain lights; in a side light the blue is scarcely visible at all: primaries with the brown costa not very broad, but the nervules appearing in the blue as brown lines; outer margius very broad brown, the blue being rather sharply defined on its outer edge: secondaries with the brown costa extending nearly to the cell, and the outer margins exceedingly broad, especially at the apex and the anal angle. Underside: both wings slightly rufous brown, with scarcely darker markings palely margined. Primaries with an indistinct spot in the middle of the cell and one at the end, below which is a very indistinct one in the lower median angle; transverse band almost straight, but with an outward inclination, composed of six small confluent spots of about equal width; occasionally there is a very slight bend at the fourth spot; submarginal row fairly distinct; marginal row almost obsolete. Secondaries with four small basal spots below each other, the third shifted outwards, followed by four rather large spots below each other, the fourth being really the eighth spot of the transverse band; cell closed by a quadrate spot, below which is a small one in the lower median angle; transverse band consisting of seven spots, the second the largest directly below the first, but with its outer edge shifted ontwards and touching both the spot closing the cell and the third spot of the band, which last is shifted right out on to its outer margin, fourth spot shifted outwards again, fitth spot slightly inwards, sixth slightly outwards, seventh spot very slightly angled, shifted inwards; submarginal row distinct, margiual row less so.

․ Upperside: both wings mauvish brown; primaries with a small riolet patch occupying the cell, the subdiscal area, and a very little of the submedian area; secondarles with the cell only occupied by some subdued indistinct violet scaling. Underside as in the male.

This species may be at once distinguished from catori mihi by its much smaller size, the very exceptionally deep purplish blue, with yet broader borders, and by its straight transverse band on the underside of the primaries. From avatha de Nicéville the exceptionally deep and dark colour of the upperside will at once separate it, as well as the more distinct markings of the under surface.

Arhopala atatha de Nicéville.

Arrhopala avatha de Nicéville, Joum. Bomb. Nat. Hist. Soc. vol. x. p. 174. 11. 23, pl. T. fig. 34, 8 (1896); de Nicérille and Martin, Journ. A. S. B. vol. 1xix. pt. 2, p. 469. n. 425 (1895).

Hab. Sumatri.

Expanse, o, 32-30 $111 \mathrm{~m}$. 
This species is very close to moorei mihi, but may be easily separated by the darker and more purplish colour and rather broader borders of the upperside, whilst beneath the transverse band differs, and in the secondaries the submarginal row is a very pronounced feature which is quite wanting in moore $i$; it is also more "spotted" than my species. From darnona semp. it can be distinguished by the purple being less dark, its borders less wide, its size smaller, whilst beneath the transverse band of the primaries is recurved, this in davaona being nearly straight.

Arhopala noorei Bethme-Baker. (Plate V. figs. 10 \& $10 \%$ )

Arhopala moorei Bethuue-Baker and Druce, P. Z. s. 1896, p. 669, pl. xxxi. fig. 1, o

IIab. Borneo; Malacca; Sumatra.

Expanse. of \& 오 $38-41 \mathrm{~mm}$.

Further material shows me that this species will not come next to metamuta, as I had originally placed it. In cle Nicéville's collection there is a very large series from Sumatra, where it is eridently a common insect; it can easily be separated from avatha de Nicéville as already mentioned. The genitalia are peculiar, the hooks are strongly curved downwards at the base, the clasps are broadish, particnlarly at the base, strongly excised in the centre of the upper margin; the penis is straight for the basal two-thirds, after which it is bent to a shasp upward curve.

Arhopala waterstradt Bethune-Bakes.

Arhopala materstradti Bethme-Baker and Druee, P. Z. S. 1896, p. 66s, pl. xxx. figs. 10 ơ, 11 o.

Hab. Borneo.

Expanse, of 42. ㅇ $40 \mathrm{~mm}$.

This species mar be separated from moorei Bethune-Baker by its decidedly larger size, very much brighter and bluer colour, and narrower margins on the upperside of the male. In the female the colour is brighter and more silvery than in the male, whilst in moorei it is darker and more violet.

I have only seen the pair sent me by Dr. Standinger, in whose museum the types remain.

Arhopala gcxoxgexsis Bethune-Baker. (Plate II. fig. 13, o.)

Arhopala gunongensis Bethune-Baker, Eut. Mo. Mag. vol, xxxiii. p. 205 (1897).

Hab. Perak (Gumong Ijau).

Expanse, of 36, if $30 \mathrm{~mm}$.

This species is an obscure little insect, and is known to me only by the two types in Mr. Rothschild's collection.

Vol. XVil.-PART I. No. 13.-August, 1903. 
Arhopala deva Bethune-Baker. (Plate V. figs, 11, 11 a.)

Arhopala deva Bethune-Baker and Druce, P. Z. S. 1896, p. 669, pl, xxxi. fig. 3.

Hab. N. Borneo.

Expanse, o \&,$+ 40 \mathrm{~mm}$.

Mr. Cator brought home a considerable series from Borneo, in which the females predominated largely. I am inclined to think that it replaces antimuta Feld. in North Borneo.

The genitalia are rery unusnal; the tegumen is very ample, hooded, and excavated in the centre, the hooks are stout with a slight downward curve, the tips very slightly spatulate; the clasps are large, excavated in the centre of the upper margin and also the outer margin, so as to make the upper extremity pointed; the inner portion of the clasps near the onter margin is studded with short spikes; the penis is long, irregular, with a globular orifice, the lower lip of which protrudes.

Arhopala antimuta Felder.

Arhopala antimuta Felder, Reise Novara, Lep. vol. ii. p. 233. n. 26 (1865).

Amblypodia antimuta (?) Butler, Trans. Linn. Soc. Loud., ser, 2, Zool. vol. i. p. 548, u. 8 (187\%). Nec Narathura entimuta Distant, Rhop. Malay. p. 266, pl. x xiii. fig. 11, q (1885).

Arhopalu antimuta de Nicéville, Butt. Ind. vol. iii. p. $2 \pi$ (1890).

Arhopalu davisonii de Nicérille, Butt. Ind. vol, iii. p. 280, froutispiece fig. 135, ठ (1890).

Arhopala antimuta Druce, Proc. Zool. Soc. Lond. 1895, p. 593.

Arrhopala davisonii de Nicéville and Martin, J. A. S. B. vol. lxiv. pt. 2, p. 469 (1895).

Nec Arhopala antimuta, iid. loc. cit.

Hıb. Malacca; Singapore Straits: Perak; Burma; Tenasserim; Borneo; Mergui.

Expanse, of \& ㅇ, $38-40 \mathrm{~mm}$.

I have carefully compared the Felderian type with all de Nicéville's specimens of davisonii de Nicérille, and find that they are identical. From deva mihi it may be separated by its darker and bluer colour (deve is bright purplish), and the shape of the wings is different, being narrower, the apex sharper and outer margins less ronnded than in my species; beneath the transverse bands are different, and my species is very spotted, the transverse bands being composed of distinct spots. From hypomutr Hew. it differs in like manner as to colour; hypomuta is bright purplish blue, with excessively fine linear margins; beneath Hewitson's species is also very much more spotted in pattern, and particularly so in the transverse bands.

Antimuta is apparently one of the commonest species in Sumatra, and Mr. Doherty considers it one of the most ubiquitous insects in the Malayan regions, and he says it is abundant in Borneo; I am, however, inclined to doubt this latter statement. I have not seen a dozen specimens from that locality, and $\mathrm{Mr}$. Cator, who evidently collected somewhat assiduously there, did not bring home from British North Borneo a single example; he, however, took a number of deva mihi, and 1 expect this is the species to 
which Mr. Doherty refers. The figure given by Mr. Distant, in his work ' Rhopalocera Malayana (l.c.), has nothing whatever to do with this species, and is quite distinct from it. The genitalia have scimitar-shaped hooks on the tegumen, the clasps are very narrow, with the extremity bluntly pointed; the penis is very small.

Arhopala brahia Bethune-Baker. (Plate II. fig. 14, o .)

Arhopala brahma Bethme-Baker, Lnt. Mo. Mag. vol, xxxiii. p. 203 (189\%).

Hab. Perak.

Expanse, o 4*2, ㅇ $45 \mathrm{~mm}$.

This species can be recognised from hypomita Hew. by its larger size and purpler colour, also by the obsoletion of the under-surface pattern, and by the lack of metallic scales at the anal angle below.

Arhorala hl'pomuta (Hewitson). (Plate II. tig. 1.j, 8.)

Amblypodia hypomuta Hewitson, Cat. Lye. B.M. p. 11, pl. vi. figs. 63 s 64,8 (1§62) : id. Ill. Diurn. Lep., Lyc. p. 1:2, pl. ii. fig. 13 (1863) ; Druce, P. Z. S. Lond. 1873, p. 354; Butler, Trans. Limn. Soc, Lond., ser. 2, Zool. vol. i. p. 549 (18;7).

Arhopela lnypomuta de Nicéville, Butt. Ind. vol. iii. p. 2r6 (1590).

Ilıb. India; Borneo; Penang; Malacca.

Expanse, of $\&$. about $42 \mathrm{~mm}$.

o. Upperside: both wings bright blue, with very tine linear hlack margins, the costa of the secondaries being broadish black, the abdominal fold greyish. Underside : botb wings warm ochreous brown, with darker spots palely encircled. Primaries with three increasing oval cell-spots, and a spot below the third in the lower median angle; bclow the second is a trace of some darker shading; transverse band composed of six spots, the first very small on the costa, second and third shifted very slightly inwards, fourth well out, fifth and sixth inwards, but inclined obliquely ontwards (Hewitson being thus right in saying " the last spot of this fascia projects outwardly"); submarginal row fairly distinct, submedian area slightly paler. Secondaries with four basal spots below each other, followed by three larger ones; cell closed by a subquadrate spot, below which is a small one in the lower median angle, and above it a small round one shifted inwards; transverse band composed of eight spots, the second placed obliquely and shifted right outwards, third shifted also well outwards, fourth out again, fifth inwards, sixth outwards, seventh angular, confluent with the eighth long spot shifted right inwards; this band is distinctly spotted, though the spots are not completely encircled with a pale edging; submarginal band distinct, marginal band obscure; a black spot at the anal angle edged above by brilliant pale blue metallic scales, which also cover the two black spots preceding it. 
․ Upperside bright violet-blue, the primaries with a broadish purplish-brown costa and very broad outer margins, the apical area being broader still; secondaries with very broad costa, the outer margin being narrow, but increasing towards the anal angle; the median and the discoidal nervules are blackish. Underside as in the male.

This species has rarely, if ever, been rightly identified with Hewitson's type and figures. In his collection are two males labelled hypomuta, one of which agrees absolutely with the figure (pl. ii. fig. 13) in the ·Ill. Diurn. Lepidoptera,' and very closely with the previous figures (pl. vi. figs. $63 \& 64$ ) given in the 'Catalogue Lycænidæ B.M.'; but the other specimen is quite different: there is no difficulty whatever, therefore, in settling which is the type, and I have taken my description of the male from the first type, whilst the female described is from singapore.

There is, however, another specimen under this name in the Hewitson cabinet, which is labelled Hypomuta amplimutr, and this no doubt has caused the confusion, more especially as the labelled female specimen belougs to this male; both are, however, absolutely distinct from Hewitson's species, but they agree fairly well with Felder's figures of amphimuta, and as he probably knew Felder's insect, we may correctly assume, I think, that they are that species. 'The figures given by Distant in his 'Rhopalocera Malayana' are probably taken from these two specimens, only his artist has thought it well to add tails to both sexes, which tney do not possess; were it not for this they would fairly well represent these insects. I have been very careful with the figures here given, and there should be no difficulty in future in recognising the species.

Arhopala metanuta (Hewitson). (Plate V. figs. 12 \& $12 a$.)

Amblypodia metamuta Hewitson, 111. Diurn. Lep., Lyc. p. 13. 1. 59, pl. ii. figs. 1+\& 15, ơ (1863);

Butler, Trans. Limu. Soc. Lond., ser. 2, Zool. vol. i. p. 518. n. 10 (18\%7).

Naruthura metamuta Distant, Rhop. Malay. p. 267. 11. 10, pl. xxiii. fig. 19, of (nce fig. 18 ơ, var. ?) (1885); Moore, Journ. Linn. Soc. Lond., Zool, rol. xxi. p. 4 (1886).

Arhopala metamuta de Nicéville, Butt. Ind. vol. iii. p. 275 (1890).

Arrhopala metamuta de Nicéville and Martin, J. A. S. B. vol. lxiv. pt. 2, p. 469.

Hab. Sumatra; Malacca; Mergui; Tenasserim; Penang; Burma.

Expanse, ơ \& ㅇ, 36-42 mm.

This species is recoguisable at once by the different blue of the two wings, the primaries being dark purplish blue, while the secondaries are lustrous azure. The genitalia are specialised, with ample tegumen and very strong short scimitar-shaped hooks; the clasps lave bilobed extremities, the outer lobe having a somewhat pointed tongue-shaped tip, and the inner lobe being spatulate, the incision being marked and moderately deep; the penis is of medium size, with a globose orifice, the lower lip of which protrudes. 
Arhop.la vita (Hewitson). (Plate V. tigs. $13 \& 13$ a.)

timblypodia muta Hewitson, Cat. Lycrenida B.M. p. 11. n. 50, pl. vi. figs. 57 \& 58 , o (1862); id. Ill. Diurn. Lep., Lyc. p. I: (I\$65).

Hril,. Java.

Expanse, of 31-37, 우 $31 \mathrm{~mm}$.

The genitalia have the hooks strongly curved downwards, with the attachment on the inside of the tegumen; the clasps are very broad at the base and at a third along the upper margin are highly excarated, the rest of the clasp being very considerably narrower.

This is a species that is reconnisable at a glance.

Arhopala alacosia (Hewitson).

Ambly/adia alaconia Heritson, Ill. Diurn. Lep., Lyc. p. 14, pl. iii. figs. 52 \& 53 (1865).

Ariopale alaconia Druce, Proc. Zool. Soc. Lond. 1895, p. 593.

Hal). Borneo.

Expanse, is ㅇ․, $4:-44 \mathrm{~mm}$.

o. Upperside: both wings dull violet, with umusually broad blackish borders all round both wings. Underside: both wings dark and olivaceous brown, with darker spots edged with cream-colour. Primaries with three increasing cell-spots ; below the second and third are two nthers divided by the lower median nervnle; transverse band composed of six spots, the first much compressed, third to sixth almost confluent, shifted ontwards, and having a slight oblique outward tendency ; the submarginal row distinct to the lower median nervule, a patch of creamy scaling between the upper three spots of the transererse band and the apex. Secondaries with spot at the basal extremity of the costa and four basal spots, the second and fourth shifted inwards, tollowed by four large ones below each other, the first and fourth of which touch the jurerious row ; cell closed by an irregular spot; transverse band composed of eight spots, the first two excessively large, confluent, and irregular, third and fourth shifted outwards, fifth smaller inwards, sixth outwards, seventh subangular, confluent with the small eighth; submarginal row distinct sublunular, with the second to fourth marks very dark; a very small metallic-blue spot near the anal angle and a dark spot at the angle.

The male and female of this species are precisely like each other. Oberthuri stgr. is its nearest ally, but it may at once be separated by the difference in colour of the upperside, and the underside of the secondaries is much more uniform than is standinger's insect.

Arhopala obertheri (Staudinger). (Plate II. tig. 16, ó.) Amblypodia oberthuri Staudinger, Iris, vol. ii. p. 132, pl. ii. fig. + (1889).

Hal. Palawan; Burma; Upper Tenasserim.

Expanse, $37-3 \delta$, ㅇ $40 \mathrm{~mm}$. 
I have before me, from the collection of Mr. de Nicéville, three specimens of this species from Tounghas (Central Burma), and one from the Dannat Range, Upper Tenasserim; they differ somewhat in that they are much greyer in the colour of the underside, and are also slightly smaller, but otherwise there is no difference whatever. From alesia Felder it differs in that it lacks a tail, and that its colour above is violetblue, not pale azure as in Felder's insect, whilst beneath it is much more uniform in general tone.

Arhopala alesia Felder.

Arhopala alesia Felder, Reise Novara, Lep. p. 235. n. 263, tab. xxix. fig. 18 (1864),

Nilasera wimberleyi de Nicérille, Proc. Zool. Soc. Lond. 188i, p. 462, pl. xl. fig. 4, q .

Arhopala wimberleyi de Nicéville, Butt. Ind. vol. iii. p. 258 (1890).

Hal. Philippine Islands; South Andaman Isles.

Expanse, of \& ㅇ, $38 \mathrm{~mm}$.

This species has a more variegated appearance beneath than oberthwi Stgr., the dark spots being darker, and the ground-colour not quite so dark, whilst the pale edging to the spots is much more marked than in Staudinger's insect, and it has also a goor many pale scales scattered more or less over its surface. De Nicéville's wimberleyi falls as a synonym to this.

Arhopala ocrida Hewitson.

Arhopala ocrida Hewitson, 1ll. Diuru. Lep., Lycæenidre, p. 146, pl. iii a. figs. 38 \& 39 (1865).

Hab. Philippines.

Expanse, of \& \& , 39-42 $\mathrm{mm}$.

On the upperside this species is almost exactly like alesir Feld., but is of a rather darker blue colour, while beneath the differences are greater. Ocido is greyer and much more uniform; it has none of the light patches of pale scales, and its pattern is smaller and not confluent, as is the case in the secondaries of alesia; there is also a distinct black lobe-spot and some metallic scaling in its neighbourbood, which is almost entirely (though not absolutely) wanting in Felder's insect. Hewitson says "this species and A. corinda scarcely differ on the underside." This is not quite accurate; there may be just at first sight a superficial resemblance, but it is exceedingly superficial. The two species are not really at all difficult to separate.

Arhopala adonias (Hewitson). (Plate II. fig. 17, $0^{*}$.)

Amblypodia adonias Hewitson, Cat. Lycrnidæ B.M. p. 8, pl. iv. ( 9 ?) figs. 32, 33 (1862); id. Ill. Diurn. Lep., Lyc. p. 9 (1865).

Amblypodia grynea Hewitson, Ill. Diurn. Lep., Lyc. p. 20, pl. (suppl.) vii. ( q ?) figs. 59 \& 60 (1878).

Hal. Java; Philippine Ísles.

Expanse, of \&,$+ 42 \mathrm{~mm}$. 
8. Upperside : both wings brilliant shining metallic emerald-green, with a slightly brassy tint; primaries with costa narrowly and posterior margin somewhat broadly blackish brown; secondaries with very broad brown margins all round, especially in the anal region : tail brown, white-tipped. Underside greyish brown, with dark spots palely encircled. Primaries with three increasing spots in the cell; beneath the second and third two more spots separated by the lower median nervule; transverse band composed of seven spots and fractured below the fourth-first spot small, second and third shifted outwards, fourth further out, fifth spot shifted right inwards, followed by two rather long oblique spots ending on the submedian nervure; submarginal shading obscure; submedian area paler. Secondaries with a small spot at the costal base; four basal spots, the fourth shifted well inwards, followed by three spots, the lowest of which is margined laterally only and is angulated in the centre; cell closed by a longish narrow spot margined laterally only, beneath which is a small triangular spot; transverse band composed of eight spots margined laterally, the second being the largest and tonching the spot closing the cell-the third spot is shifted outwards, but not detached, fourth further out, fifth well inwards, sixth outwards, seventh angular spot well inwards and touching the eighth, which is often almost broken into two spots; submarginal shading very obscure; a dark spot at the anal angle, and a trace of one hetween the second and lower median nervules, the space between and over which is sparingly filled with green-metallic scales, over which is a pale grey dusting.

ㅇ. Upperside: both wings briliiant shining pale azure-blue; primaries with costa broadly blackish brown and increasing to the apex, posterior margin very broadly blackish brown ; secondaries with very broad brown margins all round. Underside as in the male, except that the ground-colour is paler and yellower in the tint of brown.

Hewitson described the female only. Her Georg semper has been kind enough to lend me many of his specimens, and fortunately among them is one male of this species from Java; it is precisely of the same pattern on the underside as the female of adonias. Hewitson described an insect as yryner likewise from a female, but there is absolutely no difference between the two species.

The female of this species is very close to ocrida Hew., the uppersides of the females of these two species being almost identical, though the male has a greater expanse of blue in the secondaries: but beneath the difference is greater; the ground-colour of ocridt is paler and the markings more prominent, and the two transverse bands different; in the primaries this band is not completely dislocated as in adonias, and its shape in the secondaries will be readily differentiated from the description.

I have one female specimen from Mindanao, which I believe to be this insect, otherwise the species appears to be confined to the island of Java. 
Arhopala eumolphus (Cramer). (Plate II. figs. 19, 20, 21, 22 \% , $23 \& 24$ \& ; Plate $\mathrm{V}$. figs. 14 \& 14 \%.)

Papilio eumolphus Cramer, Pap. Ex. vol. iv. p. 19, pl. cexeix. figs. G, H, o (1780) ; Herbst, Pap. pl. cexcriii. figs. $3 \& 4$, o (1804).

Polyommatus eumolphus Godart, Enc. Méth. vol. ix. p. 652. и. 120 (18:3).

Amblypodia eumolphus Horsfield, Cat. Lep. Mus. E.I.C. p. 103. n. 35 (1829); Hewitson, Cat. Lyerenidæ B.M. p. 8. n. 36, pl. viii. fig. 89, ơ (1862).

Amblypodia bupola Hewitson, Ill. Diurn. Lep., Suppl. p. 21.n. 102, pl. (suppl.) vii. figs. 64 \& 65 . + (1878).

Satadra bupola Moore, Journ. A. S. B. vol. liii. pt. 2, p. 38 (1884); de Nicéville, Journ. A. S. B. vol. liv. pt. 2, p. 4. n. $302(1885)$.

Narathura farquhari Distant, Rhop. Malay. p. 264. n. 5, pl. xxiii. fig. 3, of (1885).

Amllypodia eumotphus Butler (nec Cramer), Trans. Linn. Soc. Lond., ser. 2, Zool. vol. i. p. $5+8$. n. $2(18 \pi)$.

Avhopala farquhari Doherty, Journ. A. S. B. vol. lviii. pt. 2, p. 421 (1889).

Arhopala liellenore Doherty, Journ. A. S. B. vol. lviii. pt. 2, p. 422. 1. 18, pl. xxiii. fig. $\tau$, $\delta$ (1889).

Amblypodia ermol, hus de Nicéville, Butt. Ind, vol. iii. p. 263. n. 892 (1890).

Amblypodia farquhari id. op. eit. p. 261.

Amblypodia hellenore id. op. cit. p. 265 .

Narathura maxwelli Distaut, Rhop. Malay. p. 263. n. 4, pl, xxiii. fig. 10, q (1885).

Hab. Bengal coast; Java; Sikkim; Nepal; Assam; Chittagong Hill-tracts; Burma; Malay Peninsula; Sumatra; S.E. Borneo; Palawan (Philippine Islands); New Guinea (Staudinger's coll.).

Expanse, of 41-55, 오 43-51 mm.

ㅇ. Upperside: both wings deep emerald-green, with a stroug brassy lustre in certain lights; primaries with a narrow brown costa and broad brown outer margin, this latter varies in width, and is sometimes very broad; secondaries with very broad brown margins all round; tail brown, tipped with white; lobe slightly developed. Underside: both wings palish ochreous brown. with darker brown markings encircled with whitish. Primaries with three increasing cell-spots; above the third is another small one near the costa varying somewhat in size, below it (the third) is a large spot in the lower median angle, subdiscal area dark; transverse fascia consisting of seven spots from the costa to the submedian nervure, the first three spots ontwardly oblique, fourth spot slightly dislocated and shifted yet further out, fifth strongly dislocated inwards, fifth and sixth spots inclined very slightly outwards, the lowest being shifted slightly inwards, and sometimes it is quite small, not nearly touching the submedian nervure; submarginal and marginal row uarrowish in an almost continuous line; submedian interspace pale. Secondaries with a small dot at the extreme costal base; four small basal spots followed by three larger paler spots below each other; cell closed by a long subquadrate spot, below which is a smaller one connecting it with the lowest of the 
three spots; transverse bant composer of eight spots, the second much larger, and directly below the first and tonching the cell-spot, the third shifted well ontwards, but not detached, fourth shifted outwards again, fifth inwards, sixth outwards, seventh angular spot well inwards and almost confluent with the eighth long spot; submarginal row crescentic, fairly distinct; marginal row indefinite, ending in a darkish spot on the anal lobe; no metallic scales at the anal angle.

It will be well to describe hellenore Doherty and farquhari Iristant, and show how they merge one into the another.

A. hellenove Doh.-Upperside similar in colour to that of eumolpline Cram., but with the posterior margin of the primaries black, narrow at the apex, increasing in width to the anal angle, where it is broad. Secondaries with rather more green than in the case of exmolplus. On the underside the pattern is precisely the same as in Cramer's species, but the ground-colour is rariegated with pale patches and is dark greyish ; the lobe-spot is deep black and is precerled by green-metallic scales, which are often inclined to obsolescence.

A. faiquhari Distant.-Upperside similar in colour to that of eumolphws Cramer, but with a rather narrow black posterior margin to the primaries; secondaries with rather more green than those of emmolphus. Underside: both wings uniform dull ochreous brown, with rather darker spots palely encircled, the spots being of the same tone as the ground-colour but darker. In pattern this is similar to ('ramer's species, but it has a somewhat more "spotted" appearance, and the anal angle is very strongly irrorated with brilliant bluish-green metallic scales, with a dark spot at the anal angle and beyond the tail. The female is even more uniform in colour than the male.

If we take specimens of the extreme of each form they appear satisfactorily distinct, and it is evident that this has unfortunately been done. But in examining a large series, connecting-links are shown in every grade, so that it would be impossible to say where the dividing-line should come. Hellenore Doherty is the extreme form in the one direction, with its rather more angular wing and straighter outer margin, the black border of which is quite narrow at the apex, but increases in a very defined straight line to the anal angle where it is broad, whilst beneath it is dark greçish, variegated with pale grey or bronzy-grey patches. Between this and the originallydescribed eumolphus Cramer I have before me links of every grade, forming an absolute connecting-series between the two (there are abont sixty specimens before me now, and if the two can be connected with so small a number, what would it be with a really large series?). The same remark applies to the upperside, for the width of the dark border varies in a remarkable way, being in some specimens quite an eighth of an inch wide in the narrowest part, whilst in others it is very narrow. At first sight farquhari seems to be much more distinct: the onter margin of the primaries is somewhat produced, thus giving the wings a more rounded shape; whilst the underside in extreme

VoL. XVII.-PART I. No. 14.-Alugust. 1903. 
specimens is different, the colour being very uniform darkish ochreous brown with the pattern more spotted in appearance. I have about thirty specimens, more or less typical, before me, in addition to which I have about a dozen connecting them with eumolphus Cramer, almost as closely as in the preceding instance, and one or two of the latter approaching the grey colour of the underside of farquhari Distant : the connectingspecimens are from Java, Palawan, New Guinea, Borneo, and one from Darjeeling; the typical specimens before me being from Sumatra, Borneo (S.E.), and New Guinea. I have not yet seen a typical eumolphus from the Malay Islands, but I have a link very close indeed to farquhari Distant from Darjeeling. Under these circumstances, and considering the fact that I can trace no difference whatever in the genitalia, I am forced to the conclusion that these three names represent one variable species, the female of which may be occasionally dimorphic, as in other species of this green group, for I have one or two very pale azure females which might be claimed by each of the anthors as the female of his insect. De Nicéville pointed out (Butt. India, vol. iii. p. 265) that maswelli Distant was probably the female of farquhari Distant; and he is no doubt quite correct in this, for if we compare the underside of the figures of the two insects, they will be found to agree precisely. I have mounted in balsam several genitalia of each of the named varieties, and find they all agree precisely, and in this gemus I consider this potent evidence that all are but one species. It is most probable that these very highly metallic-green colours and other such-like hues are a comparatively recent development, and we slaall therefore not expect to find the female of a similar colour. I have no doubt, as de Nicéville has already pointed out, that the supposed female described by Horsfield is no other than Pagenstecher's more recently described horsfieldi.

The genitalia of this green group are very specialised, but all follow the same main lines: the tegumen is much less ample and distinctly angled where it resolves itself into its arm-like supports; the hooks are sharply bent at their muscular attachment inside the tegumen, whence they project horizontally in a slight curve; the clasps are bilobed, the upper lobe being anvil-shaped, the upper fore extremity being sharply pointed and very highly excavated internally, whence it is projected into the long finger-shaped lower lobe, which has an upward curve. The penis is very long, with a contrary angle fore and aft, with a large trumpet-shaped orifice much expanded on its outer lip.

Arhopala aUrea (Hewitson).

Amblypodia aurea Hewitson, Cat. Lycænidre B.M. p. 8, pl. viii. figs. $87 \& 88$ (1862); id. Ill. Diurn. Lep., Lyc. p. 9 (1863).

Arhopala aurea Druce, Proc. Zool. Soc. Loud. 1895, p. 591.

Hab. Borneo (Sarawak, Labuan, Tameaug-Lajang); Sapagaya.

Expanse, o, about $45 \mathrm{~mm}$. 
This species may at once be recognised from the preceding by its very much smaller size, by its brassy-green colour, and by the quite different pattern of the underside.

The female is, I believe, entirely unknown. It is apparently a rare species, being either not represented, or, if represented, in most collections it is only by two or three specimens. Mr. Cator brought home from the small island of Sapagaya more specimens of this butterfly than I had seen before in all the collections I had been through, yet there was not a single female among them.

Arhopala bornenssis Bethune-Baker.

Arhopala borneensis Bethune-Baker and Druce, Proc. Zool. Soe. Lond. 1896, p. 666, pl. xxx. fig. $5, \delta$.

Hal. Borneo (Kina Balu, Tameang-Lajang): Malacca.

Expanse, 8* 4:-46 mm.

From aurea Hew. this species may be recognised by the deeper tone of the green, by the decidedly paler and more uniform colour of the underside, the pattern being likewise paler, aud by the pattem itself. In the primaries the transverse band is straighter and wider, in auren it is rather sharply: angular, whilst in the secondaries this band is decidedly obscure. The female of this species also is at present unknown to me.

Arhopala trogor Distant.

Arhopala troyon Distant, Ann. \& Mag. Nat. Hist. ser. J, vol. xir. p. 201 (1884); id. Rhop. Malay p. $2 \pi 5$, woodeut $8 \pi, \delta$ (1845), and p. 461 (1886).

Arhopala trogon de Nicéville and Martin, J. A. S. B. vol. Ixiv. pt. 2, p. 46z (1\$95).

Hab. Perak; sumatra.

Expanse, of 40, 우 $37-38 \mathrm{~mm}$.

This beautiful species may immediately be separated from its near allies by the purple tinge of its underside, and by the large and prominent pattern thereof. Like some others of this green group, it is apparently very local and very rare.

Arhop.la horsfield Pagenstecher. (Plate II. fig. 26, 5 .)

Amblypodia horsfieldi Pagenstecher, Jahr. des Nass. Ber. für Naturk. vol, xliii. pp. 96,106 (1890). Nec Arhopala horsfieldi de Nicéville and Martin, J. A. S. B. vol. lxiv. pt. 2, p. 46\%. n. 411 (1895).

Hab. Java.

Expanse, ơ $\$$ ㅇ $39-40 \mathrm{~mm}$.

o. Upperside: both wings dark brown, with a large bronzy metallic-green patch in the primaries from about the costal nervure to the internal margin up to half the median area, but ending abruptly at the close of the cell; in the secondaries this metallic patch is very small and does not much exceed the cell itself; tail brown, whitetipped. Underside: both wings brown, very slightly lustrous, with dark spots palely 
edged. Primaries with three increasing discal spots; below the second and third are two others divided by the lower median nervule, and above the third is a very small one on the costa; transverse fascia irregular, first spot small, second and third confluent, inclined outwards, fourth shifted well ontwards, fifth and sixth confluent and shifted right inwards, but not detached, seventh shifted slightly inwards and oblique, sometimes quite small; snbmarginal row distinct, but with obscure margins ; submedian area slightly paler. Secondaries with an ubscure spot at the costal base; four basal spots, the fourth shifted inwards on to the inmer margin, followed by three spots below each other; cell closed by a longish narrow spot, beneath which is a small triangular one; transverse fascia composed of eight spots, the second larger than the first and touching the upper outer extremity of the narrow spot closing the cell, third spot shifted right outwards but not detached, fourth further out, fifth inwards, sixth outwards, seventh angular spot inwards and tonching the eighth long one; submarginal row rather obscure: lobe-spot black; a small black spot is also between the second and lower median nervules, the space between and over which is filled with bluish or greenish-metallic scales.

․ Exactly like the male, except that the green is replaced by a violet-blue patch on the upperside of both wings, and the underside is somewhat lighter.

This species was originally described by Horsfield as the female of eumolphus Cram. It can readily be separated from all others of this group, except basiciridis de $\mathrm{N}$., by the green colour being limited to less than two-thirds of the primaries and to less than one-third of the secondaries. It is much closer to de Nicéville's insect, in the description of which species the comparison will be found : horstieldi appears to be entirely confined to the island of Java, and it is interesting to notice how very local all these green species are with the exception of eumolphus.

Arhopala basiviridis de Nicéville. (Plate 11. tig. 27, ơ ; Plate V. tigs. 15 \& $15 \%$.) Arhopala basiriridis de Nicéville, J. Bombay N. H. Soc. 1891, p. 373, pl. G. fig. 22, 6 . Arhopala horsfieldi, Druce, Proc. Zool. Soc. Lond. I895, p. 591 ; de Nicéville and Martin, J. A. S. B. vol. lxiv. pt. 2, p. $46 \tau$ (1895).

Hab. Borneo, Malacca, Burma.

Expanse, 0*, 42- $44 \mathrm{~mm}$.

o. Upperside: both wings dark brown, with a bluish-green metallic patch occupying the cell to the upper margin and one-third of the median area of the primaries. In the secondaries this metallic patch extends from just above the cell to the submedian nervule, but scarcely beyond the cell as to the outer margin. Tail brown, white-tipped. Underside: both wings of a warm brown, with slightly dlarker spots and fascia palely margined. Primaries with three gool-sized discal spots increasing in size; beneath the second and third are two other large spots separated by the lower median nervure, and above the third a small obscure spot; transverse band irregular, composed of 
seven spots, usually terminating on the submedian nervure, second spot larger and shifted very slightly ontwards, third further out, fourth still further out, fifth inwards and confluent with the sixth, which is outwardly oblique, seventh spot shifted inwards and sometimes obscure; submarginal row distinct and continuous, marginal row obscure; submedian area paler. Secondaries darker in hue, with an obscure spot at the costal base, three dark basal spots, below which on the inner margin is a rather paler one, following these are three larger spots below each other; cell closed by a longish subquadrate spot, below which is a triangular one; transverse band composed of eight syots, the second larger than the first and touching the spot closing the cell, third spot detached from the second (usually but not always) and shifted right outwards, fourth shifted further ont and confluent with the tifth, sixth shifted outwards, serenth spot well inwards and touching the long eighth spot; submarginal row fairly distinct. Three anal black spots, the middle one being almost entirely obliterated, with bluish or grecnish-blue metallic scales, which also edge the other two spots above. All the spots are rather large and the fascia edged laterally.

+ . Upperside : both wings rather pale, sublustrous, violet-blue, rather bright; cell closed by a black spot; all the horders of the primaries broadly brown, apical area very hroad; secondaries with costa and onter margin very broadly brown, decreasing at the anal angle, abdominal told greyish. Underside exactly like that of the male in every respect.

Mr. Druce has a male and temale from Burma, taken respectively at Bankasoon and Meetan; the female has the blne of an exceedingly pale lustrous azure instead of the usual riolet colour.

This species is distinct from horsfieldi Pagenst.; it is altogether a larger insect than the latter; the colour beneath is much browner and warmer in tone, making the spots much less prominent, though they are larger than in horsfieldi; the transverse fascia has a much more spotted appearance. The points of difference are difficult to describe, but are such as to separate the two species easily. The ground-colour of horsfieltit is much greyer in tone. In the female the blue of de Nicéville's insect occupies a decidedly larger area in both wings and is brighter and rather lustrons. The figures will show the differences quite readily.

The genitalia are similar to eumolphus Cram., but the hooks are straight, and the anvil-shaped part of the clasp is deeply excavated fore and aft.

Arhopala staudingeri semper. (Plate 11. tig. 2j, ơ.)

Arhopala staudingeri Semper, Schmett. Philip. Ins. Bd. v. p. 195.

Hab. Mindanao.

Expanse, ơ, $45 \mathrm{~mm}$.

ऽ. Upperside: both wings brilliant metallic green; primaries with costa narrowly dark brown, posterior margin rather broadly brown, increasing considerably at the anal 
angle; secondaries with very broad brown margins all round. Underside : both wings brown, with spots and fascia edged with white. Primaries with three large increasing discal spots; in the submedian area below the first two are two large confluent blotches making the whole basal area dark, with a pale mark showing the juncture in the middle; below the third is another spot, and above it (the third, which is very irregular and large) are two small spots, one touching it, the other on the costa ; transverse band very irregular and very broad, tonching the third spot and that below it and ending on the submedian nerrure; the first spot on the costa is small, the second and third each larger, fourth larger still and shifted outwards, fifth and sixth larger still and each shifted inwards, the sixth only as to its inner margin, seventh spot smaller, but still smaller at its lower extremity, area between this and the dark basal spots whitish; submarginal row very finely and obscurely edged with whitish; extreme margin white with an interior dark spotted row; internal area whitish grey. Secondaries with a spot at the costal base, four basal spots, the npper three touching a very large dark patch, occupying the central and upper part of the wing from the costal to the median nervures; the spots in the centre of the cell and closing it marking its lower extremity at the costal nervure, a white mark showing that the spots have become conflnent; transverse band beginning on the lower discoidal nervure and tonching the large patch; the second oval spot is shifted inwards, third outwards, fourth very large angular spot inwards and confluent with the fifth long spot; subapical area whitish grey; submarginal row indefinite, the three lower spots being very dark with obscure internal definitions; lobe fairly developed, with a black spot followed by two subanal black spots, the middle one being almost obliterated with bright blue-metallic scales, which also edge the other two spots above; tail brown, white-tipped, over the metallic spots is a greyish irroration; margin finely whitish.

I have only one male before me, but it appears to be quite a distinct species. the pattern beneath being very distinctive. The rery striking and handsome underside of this species should separate it without the least difficulty from all its allies.

Arhopala anella de N.

Arhopala anella de Nicéville, Journ. Bombay Nat. Hist. Soc. vol. ix. p. 289, pl. P. fig. 32 (1895).

Hab. Perak, Malay Peninsula.

Expanse, ㅇ, $51 \mathrm{~mm}$.

The unique type specimen is before me and is certainly a distinct species, its nearest ally being irregularis Röber, also a three-tailed species; it has, however, a much larger area of blue on the upperside, whilst beneath the colour is very much paler and ochreous, and the spots fewer and more separated than in Röber's species. 
lahopala IRregularis, n. sp. (Plate II. fig. 1s, q.)

Hah. C'elebes, Banka.

Expanse, o* 38-43, \& $35-38 \mathrm{~mm}$.

$\therefore$. Upperside: both wings very deep, slightly shining, violet-blue; the primaries with costa broadly, apical and posterior marginal areas very broally purplish black; secondaries with very broad margins all round, anteciliary line black, edged internally from the upper median nervule to the anal angle with white; fringes to both wings tipped with white. Three tails fine brown, each white-tipped, central one very long. Underside: both wings greyish brown, witl very dark spots edged with white. Primaries with a small spot at the extreme base of the cell, followed by two larger roundish ones, the third well before the end of the cell; two small spots are over the second and in advance of it, the upper one touching the costa, one spot is over the third and in adrance of it, and touches a very broad irregular fascia which crosses the end of the cell; this faseia is narrower on the costa and terminates very widely on the lower median nervule, and in its centre is a faint white dash indicating the end of the cell. Transverse fascia very imegular, edged laterally only; the second spot with its outer margin shifted ontwards, third with the inner margin shifted inwards, fourth ontwards and angulated in the centre of its inner margin, fifth right inwards, with its onter margin slanting outwards and its inner very oblique and slightly angulated, sixth spot shifted slightly inwards and oblique; below this under the lower median nervule is an indefinite small oblique dash; submarginal row distinct, the lower spots very much suffused inwardly and large, the three upper ones being quite >-shaped and much suffused inwardly with whitish; marginal stripe dark almost obsolete in centre; anteciliary line dark, edged internally with whitish; submedian area greyish white, underneath the base of the cell slightly darker. Secondaries darker than the primaries, with a guodsized spot at the costal base; a basal row of five spots all touching, the third and fourth shifted outwards, the fifth beyond the internal nervure unusually large, followed by three large spots, the upper one pear-shaped; cell closed by a large spot with a pale central dash, below which is a narrow suboval spot: transverse band very irregular and edged laterally only, the upper spot having a double curve, followed by a larger one whose lower inner margin touches the large spot closing the cell; third spot shifted right outwards, fourth outwards again, the fifth spot oblique, shifted inwards, sixth merely a very dark narrow stripe, seventh and eighth also confluent, shifted right inwards and little more than a very dark narrow stripe; ontside the three upper spots there is a very dark suffusion up to the pale edging of the narrow scalloped submarginal stripe, which stripe is continued from the costa right round above the metallic scaling to the internal nervure; a black spot at the anal angle and between the second and lower median nervules, the space between and over which is broadly filled with brilliant bluish or greenish-bronzy metallic scales, which also extend into the upper median space; anteciliary line very dark, edged internally with whitish. 
ㅇ. Upperside : both wings warm brown; primaries tinged with a shade of purple, with a good-sized bright violet patch up to half the median area; cell closed by a dark spot, this patch being smaller in the secondaries. I have before me one specimen from Banka in which the shade is as deep in tone as in the male, but it is more violet in hue.

This species is very strikingly marked on its underside and should be recognised at once; it is perliaps nearest to abseus Hew., but can be very easily separated by its very much larger size, by the umusually broad borders of the male and the very dark blue of the upperside, whilst on the underside the spots are very much more distinct and are markedly outlined with whitish, whereas abseus is more uniform in tone and darkly clouded. The specimen figured is a female in my own collection; it would have been better had I figured the male, which is much more distinct. but I had returned the male specimens to Herr Ribbe before I was ready to figure it.

Arhopala abseus (Hewitson).

Amblypodia abseus Hewitson, Cat. Lycenidæ B.M. p. 9. n. 40, pl. v. figs. 41 \& 42 (if corrected in IIS., then figs. 51 \& 52), \& (1862); id. Ill. Diurn. Lep., Lyc. p. 10. 11.44(1863); Druce, Proc.

Zool. Soc. Lond. 1873, p. 353. 1. 6.

Satadra abseus Moore, Journ. A. S. B. vol. liii. pt. 2, p. 41 (188t).

Arhopula abseus de Nicéville, Butt. India, vol. iii. p. $24: 2$.

Arhopala amphea Felder, Reise Novara, Lep. p. 234, tab. xxix. fig. 19 (1865); Druce, Proc. Zool

Soc. Lond. 1895, p. 589 ; de Nicéville and Martin, J. A. S. B. vol. lxiv. pt. 2, p. 465 (1895).

Hab. Sylhet; Sikkim; Burma; Mergui; Singapore; Sumatra; Borneo.

Expanse, ơ 우, 36-41 $\mathrm{mm}$.

o. Blue areas distinctly fractured beyond the lower median nervule, where the fascia becomes very narrow ; below the upper discoidal nervule is a dark patch extending to the margin, submarginal row obscured. A black spot at the anal angle and between the second and lower median nervules, over and between which are some greenish submetallic scales more or less scattered, margined above with a dark dash up to the abdominal margin. The secondaries are glossy and the spots much darker than in the primaries.

ㅇ. Exactly like the male, except that the blue is paler and more restricted.

All the male specimens from Borneo that I have seen are quite glossy purple. The species is very different from any others except irregularis and should be recognised without difficulty.

Arhopala amphea Felder.

Hab. Philippines.

Expanse, of $35-45$, ㅇ $33-44 \mathrm{~mm}$.

This is, without doubt, a local race of absens, being merely of a darker blue above, with the borders not so broad. 
Arhopala kuhri (Röber). (Plate II. figs. 28 o , 29 ㅇ.)

Amblypodia kuhni Röber, Iris, vol. i. p. 200, Taf. ix. figs. 5 \& 8 (1887).

Hab. Isle of Banka.

Expanse, ot 47, ㅇ $38 \mathrm{~mm}$.

This species should at once be recognised by the female, which is peculiar in the dark spots of the upperside closing the cell on both wings, which are specially noticeable on the secondaries, and by the three tails.

The male is of a violet shade, not purple above, aud is easily recognisable from diardi Hew. by the compact dark basal area and by having no purplish tinge below, and from fulyide by a similar difference in colour, and by its decidedly larger size, whilst the contour of its primaries differs from both, the onter margin of the apex being nearly straight, with a slight excavation in the median area.

Arhopala diardi (Hewitson). (Plate T. figs. 16 \& 16 a.)

Amblyporlia diardi Hewitson, Cat, Lycienidæ B.Mi. p. 9. n. 43, pl. ₹. figs. 51 \& 52 (if eorreeted in

IIS. then figs. 41 \& 42), of (1862); Druce, Proc. Zool. Soe. Lond. 18\% 4, p. 10\% n. 2.

Amblypodia? diardi Butler, Trans. Linu. Soc. Loud., ser. 2, Zool, rol. i. p. 519. n. 13 (18\% ).

Satadra diardi Moore, Journ, A. S. B. vol. liii. pt. 2, p. 41 (1884).

Panchala diardi Distant, Rhop. Malay. p. 272. n. 1, pl. sxiii. fig. 14, f (1885).

Arhopala diardi de Nicéville, Butt. India, vol. iii. p. 256 (1890); de Nicéville and Martin, J. A.

S. B. vol. Ixiv. pt. 2, p. 466 (1895).

Amblypodia capeta Hewitson, Ill. Dium. Lep., Suppl. p. 22, pl. viii. figs. 70 \& 71 (18z8).

Amblypodia viardi Standinger, Iris, vol. ii. p. 130 (1889).

Ilab. India; Assam; Siam; Penang; Malacca; Singapore: Sumatra; Palawan; Bosobusa (Philippines); Mindanau; Java; Borneo; Celebes.

Expanse, 우, $40-48 \mathrm{~mm}$.

I have before me a specimen of this insect trom Palawan of a most beautiful rich blue, almost as beantiful as amiclla, but with a purple tinge in it ; the underside, however, agrees entirely with this species, it has but little of the red at the base. I have compared Hewitson's capeta very carefully with this species and can finl no ralid points of difference.

It is very close to the next species, fulgitr Hew., but is decidedly darker and more violet in the tone of the underside, and has the very finest possible dark linear onter margin and costa, whereas fiulgide has both these margins decidedly wider though still narrow. Its distribution is extensive, occurring from the Khasia Hills (Assam) to the Philippine Islands on the east, to Sumatra on the west, into Java, where apparently it is not uncommon, and probably in suitable places throughout Borneo, as I have specimens from the south-east of the island and from the coast opposite Labuan.

I bave before me one extraordinary male from Lompa-Battan (Celebes), taken about 3000 feet high in March 1896, in which the underside is extremely dark; whilst it VOL. XVII.-PART I. No, 15.-August, 1903. 
measures in expanse no less than $66 \mathrm{~mm}$. In the genitalia the tegumen is very simple with hardly any hood and the sides very broad almost to the juncture with the clasps; the hooks are long, angled alnost at $45^{\circ}$ about their centre, and fixed very close to the top of the tegumen; the clasps are small; the penis is rather like that organ in the eumolphus group, but much shorter, not having the narrow internal portion as in that section.

\section{Arhopala fulgida (Hewitson).}

Amblypodia fulgida Hewitson, Ill. Diurn. Lep., Lycænidæ, p. 11. n. 49, pl. v. fig. 31, o (1863). Nilasera? fulgida de Nicéville, Journ. A. S. B. vol. liii. pt. 2, p. 80. n. 21, pl. ix. figs. $3 \delta, 3 a q$ (1883).

Satadra fulyida Mloore, Jomru. A. S. B. vol. liii. pt. 2, p. 41 (1884).

Arhopala fulgida de Niceville, Butt. India, vol. iii. p. 254 (1890).

Panchala sinyapura Distant, Rhop. Malay. p. 273, woodeut 84 (1885).

Hab. Philippines; N. India; Sikkim; Khasia Hills; Singapore.

Expanse, of 40-49, क $45-46 \mathrm{~mm}$.

This species may be safely recognised from the preceding, $A$. diardi Hew., by the slight differences of the upperside as already enumerated under that species, but more especially by the fact that the subbasal broad dark band is always unbroken.

$A$. fitlgidla has a much more restricted range than diurdi. The genitalia are of just the same type as in diardi Hew., but the hooks are angled at a third from their attachment and the clasps are much more pointed.

Arhopala anniella (Hewitson).

Amblypodia anniella Hewitson, Cat. Lycrenidæe B.M. p. 10, pl. viii. figs. 83 \& 84, ठ (1862).

Narathura anniella Distant, Rhop. Malay. p. 269, pl. xxi. fig. 20 (1885).

Arhopala anniella Druce, Proc. Zool. Soc. Lond. 1895, p. 592; de Nicéville and Martin, J. A. S. B. vol. Ixiv. pt. 2, p. 468 .

Arhopala triangularis Stgr. (in litt.).

Hab. Singapore; Province Wellesley; Perak; Sungei Ujong; Borneo; Batchian (Semper); Java; Philippine Islands ; Sumatra; Tenasserim.

Expanse, of 40, o $38-40 \mathrm{~mm}$.

Mr. Distant has severely strictured Hewitson's figure of this species, yet his own is but little better; in shape it is worse than the original figure; the costa and posterior margin of the primaries should be much straighter, especially the former, and the tip of the apex slightly produced, whilst the secondaries are absolutely wrong in shape and should be as described already, instead of rounded as figured by Mr. Distant.

The rich beautiful blue of the male will separate it from any of its near neighbours, whilst below it is much more uniform in tone, and the secondaries are rery dark rich purplish red, washed here and there with very pale lavender scales, and it has no 
distinct tail, only a very slight tooth. The specimens, however, from the Philippines and Batchian and Malacea have a slight tail and are not so uniformly dark as those from Borneo on the underside of the secondaries. These specimens seem to form a sort of "transit" to fulgitle Hew, as the upperside is not so intensely blne as in the Bornean specimens. It appears to be a local and rare insect, as only 19 specimens have passed through my hands, and I have not seen many in any collection, except that of the late Mr. de Nicéville, which contained 12, and added to our knowledge of the distribution of the species, there being specimens from Perak, Sumatra, Penang, and Tenasserim (Dannat Range).

Arhopala artegal (Doherty).

Flos artegal Doherty, J. A. S. B. vol. Wvii. pt. 2, p. 423, pl. xxiii. fig. 5 (1859).

Arhopala artegal de Nicéville, Butt. 1nd. vol. iii. p. 225 (1890).

Hab. Mererui.

Expanse, 8, $85 \mathrm{~mm}$.

I have not seen this species, but from the figure it is very elose to amiella Hewitson. Mr. Doherty states that the two specimens he took were males; were it not that he is so accurate an observer I should doubt this, and if one can judge from the figure there is every appearance of a female in the shape of the wings. It is not impossible that these may prove to be females of Hewitson's previous species.

Arhop.lla apidanus (Cramer). (Plate V. figs. 17 \& 17 a.)

Papilio apidanus Cramer, Pap. Ex. vol, ii. pll. cxxxvii. figs. F \& G, $\delta$ (17at); Vabricius, Lep. Ins. vol. ii. p. 119. 11. 530 (1781); id. Mant. Ins, vol. ii. p. 69. 11. 658 (1787).

Hesperia apidanus Fabricius, Ent. Syst. vol. iii. pt. 1, p. 280. n. is (1793).

Polyommatus apidamus (Godart, Enc. Méth. vol. ix. p. 652. n. 118 (1823).

Amlilypodia apidanus Horsfield, Cat. Lep. Mus. E.I.C. p.100. n. 32 (18:9); Horsfield and Moore, Cat.

Lep. Mus. E.I.C. vol. 1. p. 39. 11. 53, pl. i. figs. 5 larva, 5 a pupa (1857); Butler, Cat. Fabr. Lep.

B.M. p. 180. n. 2 (1869); id. Trans. Linn. Soc. Lond., ser. 2, Zool. vol. i. p. 519. n. 12 (1877). Satadra apilanus Moore, Journ. A. S. B. vol. liii. pt. :2, p. 41 (1884).

Panchala apidanus Distant, Rhop. Malay. p. 273. 11. 3, woodeut n. 85, of (1885).

Thecla apridanus Horsfield, Cat. Lep. Mus. E.I.C. pl. iv. figs. 3 larva, 3 a pupa (1829).

Amllypodia apidanus Druce, Proc. Zool. Soc. Lond. 1873, p. 353. 1. 7.

Papilio dorimond Stoll, Suppl. Cramer, pl. xxxvii. figs. $4,4 a$, $q$ (1790).

Arhopala apidanus de Nicéville, Butt. India, vol. iii. p. 253 (1890); Druce, Proc. Zool. Soc. Lond. 1895, p. 590.

Arrhopula apidanus de Nicéville and Martiu, J. A. S. B. vol. lxiv. pt. 2, p. 466 (1895).

Var. palawanus Staudinger, Iris, vol. ii. p. 130 (1889).

Flos ahamus Doherty, J. A. S. B. vol. 1x. pt. 2, p. 33, pl. i. fig. 6, ㅇ (1891).

Hab. Mergui; Moulmein; Malacca ; Singapore; Sumatra; Java; Borneo; Nias ; Tenasserim; Philippines; Sambawa; Balabac; Assam.

Expanse, of $q$, 38-50 mm. 
The females of this species are subject to variation as to the colour of the blue; I have two with a very pale silvery-blue tinge, many are pale purplish, others are quite dark blue, and some pale violet.

All my Java specimens are of the brilliant or silvery-blue forms, but the other forms appear to obtain indiscriminately in Nias, Sumatra, the Philippines, and Borneo. I cannot trace any difference between this and Dr. Staudinger's palawanus; the colour of the under surface is rather paler, but otherwise they are essentially the same. I have two or three females entirely brown, with no blue area at all. The red basal area varies considerably in the secondaries; I have specimens in which there is quite a suffusion of it, whilst in some it is almost absent, but I believe the streak on the costa of the primaries is always present. This strongly marked species is widely distributed, it having been taken in Moulmein, Burma (de Nicérille has sent me two from Tenasserim in his collection), Mergui, Penang (Herr Semper has sent me a pair from this island), Malacca, Singapore, Sumatra, Nias (Semper), Java, Sambawa (my specimens from this island are of the ordinary form, Doherty says a local race occurs in the hills), Celebes (where a beautiful local race has apparently been set up), Borneo, and the Philippines.

I have no doubt whatever that Doherty's Flos ahamus is merely a pale form of this species. The genitalia are specialised in every point, the tegumen with its extraordinary beak-shaped hook and projection below this, the hooks recurved at their tips; the clasps small and evenly oblong; the penis stout, curved, with a globose orifice, at the tip of which is a strong thorn-like spur.

Arhopala arca de Nicéville.

Arhopala arca de Nicérille, Journ. Bomb. Nat. Hist. Soc. vol. vii. no. 3, p. 331. u. 8, pl. H. fig. 15, \& (1892).

Hab. Celebes.

Expanse, \&, $49 \mathrm{~mm}$.

This may be the Celebes form of apidanus Cram.

+ . The upperside is like the very pale silvery-blue form of Cramer's insect, but the blue is more restricted. Below it is plain dark brown and whitish, all trace of red or pink or lilac is quite gone, there being also no trace of the red costal streak in the primaries nor of the basal streak in the secondaries; in the primaries the markings are the same, but greyish white takes the place of the lighter brown interspaces and the submedian area, and the lilac scaling at the apex is replaced by light grey; the same differences obtain in the secondaries, and the fringes are wholly tipped with white, which gives the insect a very striking appearance.

I have before me the unique type from which de Nicéville described the species, and if all examples from Celebes agree with that specimen, it makes a very fine local race. 
Arhopala morphiNa (Distant). (Plate II. fig. 30, o .)

Panchala morphina Distant, Ann. \& Mag. Nat. Hist. ser. 5, vol. xiv. p. 201 (1881) ; Rhop. Malay. p. 27t, woodeut 86, ơ (1885).

Arrhopala morphina de Nicéville and Martin, J. A. S. B. vol. Kxiv. pt. 2, p. 468 (1895); Druce, Proc. Zool. Soc. Lond. 1896, p. 666.

Hal. Malacea; Snmatra; Borneo; Silam.

Expanse, of $46-50$, o $48 \mathrm{~mm}$.

+. Upperside: both wings pale violet; primaries with a broad brown costa up to the cell, a very broad and slightly increasing (as it nears the apex) outer margin, and yet broader apex; secondaries with very broad costa and broadish outer margin, increasing very considerably at the anal angle; underside exactly like that of the male.

Until now the female of this species does not appear to have been recorded; but Mr. Cator was fortunate enough to capture one at Silam, an island off the coast of British N. Borneo, on the 26th of January, 1892, which is the type female and is in his collection.

This species, though by no means the largest in size, is, I think, about the most magnificent of the genus. the intense richness of the deep ultramarine-blue of the upperside and the most beautiful softuess of the tones of the under surface, coupled with the rich depth of the basal area, combine to make it a species so striking that once seen it will never be forgotten. It appears to be a rare insect; I have only seen a single specimen from each of the localities given, each of which is from a different collection.

Arhopala adriava (de Nicéville). (Plate V. figs. 18 \& 18 a.)

Nilasera? adriana de Nicéville, J. A. S. B. vol. liii. pt. 2, p. 79. n. 20, pl. ix. figs. 5 o, 5 a 우 (1s83).

Arhopala adriana de Nicéville, Butt. Ind. rol. iii. p. 253 (1890).

Hah. Sikkim.

Expanse, of $46-50$, f $46-48 \mathrm{~mm}$.

This species is quite distinct and easily separated from apidanus Cram. by the broad outer border to the primaries, and by the underside pattern, which is quite different; the broad outer border of the primaries also separates it from asok $u$ de N. It is a very lncal insect, only having been recorded from Sikkim; I have specimens also from Darjeeling. The genitalia are most peculiar; the tegumen is elevated into a high saddle-back ridge, and then carried forwards into two strong, curved, pointed tusks, jointed at the base with the tegumen, below which are the usual hooks. The clasps are composed of two portions, the hinder portion extending upwards with a hammershaped head, the fore portion small, subtriangular, joined at its lower hind extremity to the other part. The penis is stout, strongly curved in its whole length. 
Arhopala asoka (de Nicéville).

Nilasera? asoka de Nieéville, J. A. S. B. vol. liii. pt. 2, p. 78. n. 19, pl. ix. figs. 6 ఫ̋, $6 a$ q (1883). Satadra chola Moore, J. A. S. B. vol. liii. pt. 2, p. 39 (1884). Arhopala asoka de Nicéville, Butt. Ind. vol. iii. p. 253 (1890).

Hab. Sikkim; Burma (Bhamo) (Standinger).

Expanse, of 48-49, ㅇ 46-48 mm.

A close ally of adriana de Nicév.; besides the difference in the outer margins, as already indicated under that species, it may also be separated by the presence of metallic-green scales at the anal angle, which are not present in adriana; the markings are more pronounced on the underside of the secondaries, especially the subbasal band, which is generally very dark and well marked.

This is another very local species, though of wider range than the last, as besides specimens from Sikkim I have a couple from Bhamo (Burna). The genitalia are closely similar to those of the prerious species, but the fore portion of the clasps is rather larger.

Arhopala chinensis Felder. (Plate III. fig. 1, o ; Plate V. figs. 19 \& 19 a.)

Arhopala chinensis Felder, Reise Novara, Lep. vol, ii. p. 231. n. 25\%, pl. xxix. fig. 10, ơ (1865).

Amblypodia chinensis Moore, P. Z. S. Lond. 1865, p. 7 it; Hewitson, Ill. Diurn. Lep., Lyc. p. I4g. n. 96 (1869).

Satadra chinensis Hoore, J. A. S. B. vol. liii. pt. 2, p. 41 (1884).

Nilasera? moelleri de Nicéville, J. A. S. B. vol. lii. pt. 2, p. 80 , pl. ix. figs. $1 \delta,+a$ \& (1883).

Satadra lazula Moore, J. A. S. B. vol. liii. pt. 2, p. 40 (1884).

Arhopala moelleri de Nicéville, Butt. Ind. vol. iii. p. 266 (1890).

Hub. Shanghai ; Sonth China; Darjeeling; North India; Sikkim; Khasia Hills; Sibsagar, Upper Assam.

Expanse, of $47-50$, of $43-47 \mathrm{~mm}$.

․ Upperside: both wings purplish brown, with a purplish-blue central patch, in the primaries extending orer the discoidal cell, the submedian and about half of the median areas, in the secondaries extending just ontside the cell and about halfway beyond towards the outer margin. Underside precisely as in the male.

Felder's species chinensis has for long remained practically unknown, and I was surprised in looking at this type in Mr. Rothschild's Museum to recognise it as probably moelleri de Nicév. I have since carefully examined it with a number of de Nicéville's species and I have no donbt it is that insect. There are two slight differences: in the type chinensis is a small light spot on the underside near the base in the cell of the primaries, this is not present in ordinarymollevi de Nicev., but there are indications of it in several specimens before me; and in the secondaries the broad dark band at the base is more broken up on its outer margin than is the case with 
moelleri, this, however, is decidedly variable in the specimens before me of the latter sprecies. Inder these circumstances I have no option but to sink de Nicéville's moflleri under chinensis Felı. My figure is taken from Felder's type. The genitalia have the tegumen highly excavated, so that the apex is produced into a strong curved hook, the hooks themselves are sharply angled, the clasps are in two portions, the fore portion receding within the hinder portion to a large extent, the latter being rather small. The penis is very stout and strongly curved.

Arhopala areste (Hewitson).

Amblypodif areste llewitson, Cat. Lyc. B.M. p. 10. n. 44, pl. v. figs. 13 \& 4 , ? (1862).

Nilesera? areste de Nicéville, J. A. S. B. vol. lii. pt. 2, p. 97. 11. 217 (1883).

Sutadra areste Moore, J. A. S. B. vol. liii. pt. 2, p. 41 (1884).

Satudre fatuma Nloore, tom. eit. p. 10.

Arhopala areste de Nicéville, Butt. Ind. vol. iii. p. 271 (1890).

Hrib. Nepal; sikkim; Khasia Hills.

Expanse, of \& ㅇ, $33-41 \mathrm{~mm}$.

This species is very close indeed to chinensis Feld., from which it may be separated by the different colour and pattern of the underside of the secondaries, by the absence of any metallic scales at the anal angle, and by the absence of any red at the base of the primaries, and in a lesser degree by the tact that chinensis has an exceedingly short tail, little more than a tooth perhaps, but in areste this is represented only by the outline of the wings being strongly scalloped.

It has hitherto been taken only in sikkim and Assam; de Nicéville says it is a rare species, occurring at low elevations in August, September, and November, so that it is one of the most restricted species of the genus. The genitalia are very close to the previous species, but the clasps are more pointed and clifferently placed.

Irhopala bazalus (Hewitson).

Amblypodia bazalus Hewitson, Cat. Lyc. B.M. p. 8. n. 38, pl. iv. figs. 37 \& 38, f (1862).

Situdra bazalus Moore, J. A. S. B. rol. liii. pt. 2, p. 39 (1884).

Sutull ra teestu de Nicéville, J. A. S. B. vol. lv. pt. 2, p. 253. n. 6, pl. xi. fig. 3, б (1886).

Arhopalu teeste de Nicéville, Butt. Ind. vol. iii. p. 250. n. 806, pl. xxvii. fig. 197, бo (1890).

Arrhopela teesta de Nicéville and Martin, J. A. S. B. vol. lxiv. pt. 2, p. 466. n. 400 (1895).

Nee trhopala bazalus de Nicéville, Butt. Ind. vol. iii. p. 249. n. 804 (1890).

Hub. Sikkim; sylhet; Upper Tenasserim; Snmatra; Borneo; Japan.

Expanse, of \& ㅇ, $46-54 \mathrm{~mm}$.

*. Upperside: both wings excessively deep dull purple, suffused with a silkybrown lustre; primaries with the costa very narrowly, and the outer margin less narrowly black: secondaries with the costa very broadly and the outer margin less broadly blackish. Tail blackish, tipped with white, moderately long. Underside exactly like that of singla de Nicév., except that in the primaries the transverse band 
is usually extended to the submedian nervure instead of to the lower median nervule only, whilst in the secondaries there is usually a very distinct though sparing scaling of metallic-green colour at the anal area.

ㅇ. Indistinguishable from singla, except perhaps by the green-metallic scaling of the anal area.

I have very c.... fully compared de Nicérille's species A. teeste with this species of Hewitson's and find they are identical in every particular. A. bazalus Hew., of de Nicéville's 'Butterflies of India,' no. 804 , p. 249, vol. iii., should be referred to A. bazaloides Hew.

The ordinary form of this insect is intensely deep blackish purple, but this varies, even in specimens from the same locality. From the Khasia Hills I have specimens as dark as any I have seen, and I have also a few specimens not nearly so dark, of merely a dark sublustrous violet-purple. The width of the border varies also in like manner, some are almost linear, whilst others are broader, and one specimen, lent me by Mr. Druce, is most remarkable in this respect, the border being nearly an eighth of an inch wide and increasing at both the apex and anal angle.

Turbata Butl., from Japan, is, without doubt, the same species, the only difference being that the underside is perhaps a little more uniform; the pattern is precisely the same, and it varies in the blue of the upperside exactly in the same manner as do the Khasia Hill specimens. It is a widely distributed insect, though apparently local: the types are from Sylhet and Java; it also occurs in Sikkim, Assam, Upper Tenasserim, Sumatra, Java, S.E. Borneo (from where I have one female), and Japan.

Arhopala singla (de Nicéville). (Plate T'. figs. $20 \& 20 a$.)

Satadra singla de Nicéville, J. A. S. B. vol. liv. pt. 2, p. 119, pl. ii. figs. 7 \& , 8 o (1885); id. Butt. Ind. vol. iii. p. 250 (1890).

Hab. Sikkim; Burma (Shan States).

Expanse, of about 46 , of $46-50 \mathrm{~mm}$.

De Nicéville says: "I have no doubt whatever that $A$. singla and $A$. teesta (i. e. bazalus Hew.) represent two perfectly distinct species, as the males can be distinguished at a glance by the coloration of the upperside; but as the undersides of the two species are alike $I$ do not know how their respective females from Sikkim are to be recognised. As $A$. singla is only known from Sikkim, females from other localities may safely be placed under A. teesta (i. e. bazalus Hew.) (Butt. Ind, vol. iii. p. 250)." I have no doubt that this remark is quite correct. A. singla is evidently a local and not common species, at least A. bazalus is sent to this country in far greater numbers, but since de Nicéville wrote as above the species has been taken in the Shan States of Upper Burma. The genitalia hare a good-sized tegumen, the hooks of which are strongly curved at their bases, the clasps have a long arm-like extension; the penis is stout, rather long, with a trumpet-shaped orifice. 
Arhopala corinda (Hewitson). (Plate III. fig. 2, ot.)

Amblypodia corinda Hewitson, Ill. Diurn. Lep., Lyc. p. $14 c$. n. 81, pl. iii $a$. figs. 34 \& 35 万人, 33 우 (1865).

Arhopala acestes de Nicéville, Journ. Bomb. Nat. Hist. Soc. vol. vii. p. 330, pl. H. fig. 14, §ే (189:2).

HIab. Philippines; Malacca; Penang; Perak.

Expanse, of \& o , $42 \mathrm{~mm}$.

ह. Upperside: both wings shining brownish violet, central area brown. Costa and posterior margin of primaries very finely blackish; costa of secondaries broally brown, posterior margin finely black; tail black, white-tipped, and a short tooth-like projection at the end of the second median nervule. The exact hue of this insect is difficult to describe; the discoidal, submedian, and median areas are really brown, with a broad costa and narrow posterior and interior margins of a subdued lustrous violet, so suffused that the interior boundaries are not determinable; the secondaries are entirely of this subdued violet except the costa, whilst in certain lights the whole surface looks lustrous brown. Underside: both wings warm brown, with darker spots margined with whitish grey. Primaries with three increasing discal spots and below the thirl a smaller one; the basal area between the cell and the submedian nervure is darker brown margined outwardly with a pale line; area beneath the lower median nervule pale greyish; transverse band composed of five spots, contuent, the first to the third ontwardly inclined, especially the third, fourth and tifth shifted slightly inwards, submarginal row very obscure. Secondaries with a small spot at the costal base, fonr basal spots, the third shifted slightly outwards, and fourth inwards beyond the internal nervure, followed by three larger spots below each other; cell closed by a larger spot, beneath which is a smaller triangular one; the two upper spots of the transverse band are quite disconnected from the others but touch the large spot closing the cell, third spot of transverse band shifted right outwards, fourth outwards again. fifth well inwards, sixth outwards, seventh angular spot inwards and conflnent with the eighth long spot; submarginal row indefinite but distinct, followed by a marginal lunular row; a velvety-black spot is at the anal angle and between the lower and second median nervules, the space between and over which is filled with bright bluish-metallic scales.

. . Lpperside: both wings blackish brown; primaries with the discoidal, submedian, and two-thirds of the median area bright blue, which is invaded at the end of the cell by a black spot; secondaries with a much smaller and narrower bright blue area, also interrupted by a black spot closing the cell. Underside as in the male, but submarginal row distinct in primaries, and the upper two spots of the transverse band just comnected with the others; the colour is much greyer in parts than in the male.

In certain lights the blue of the upper surface is a true blue, whilst in others it has a purplish tinge.

FoL. XVII.-PART I. No. 16.-August, 1903. 
I have very carefully compared de Nicérille's acestes with this species and find it is identical; the upper surface of his two specimens (one from Perak and the other from Penang) is a shade purpler, but I have one from Dr. Staudinger from Malacca which is of the ordinary colour, and the underside pattern is precisely similar in all. The colour of the upper surface and the distinct markings of the underside at once separate it from any other species. Its distribution is peculiar, it hitherto having been recorded only from the Philippine Islands, Malacca, and Penang.

Arhopala bella Bethune-Baker.

Arhopala bella Bethune-Baker and Druce, P. Z. S. Lond. 1896, p. 661, pl. xxx. figs. 6 o , 7 q .

Hab. Kina Balu (Borneo).

Expanse, ơ 55, ㅇ $45 \mathrm{~mm}$.

This very beautiful and (in the male) very unusual looking species will come next to $A$. corinda Hewitson, but may at once be recognised by its large size, its brilliant purple margins, and its lustrous brown inner areas: the transverse bands are also somewhat different. A. corind a below has a more spotted appearance than $A$. bella .

Arhopala buruexsis Holland.

Arhopala buruensis Holland, Norit. Zool. vol. vii. p. 78 (1900).

Hab. Buru Island.

Expanse, ơ 32, ㅇ $30 \mathrm{~mm}$.

I have not seen this species, which Mr. Holland places near my kounga (the azimis de N.), and in my inability to compare the types it is impossible to do more than record the species, which in this section of the group are differentiated by so small or inconspicuous markings that it is not safe to make any remarks on the insect unless we have the species before us.

Arhopala aziNis de Nicéville.

Arhopala azinis de Nicéville, Journ. Bomb. Nat. Hist. Soc. 1895, p. 3, pl. T. fig. 31.

Arhopala kounga Bethune-Baker and Druce, P. Z. S. Lond. 1896, p. 662, pl. xxx. fig. t, of (nec fig. 3, ठ).

Arrhopala azinis de Nicéville and Martin, J. A. S. B. vol. lxir. pt. 2, p. 466. n. 403 (1895).

Hab. Sumatra (N.E.); Borneo (Kina Balu).

Expanse, o \& \& , $34 \mathrm{~mm}$.

ㅇ. Upperside: both wings like the male, but blue slightly more violet and much less extensive, the primaries having a large black invading patch at the end of the cell.

My description of kounga appeared just after de Nicéville's had been published, and I find the male figured in my paper is only a curious form of aroa, the female being that sex of de Nicéville's species. In that specimen, however, the black invading patch 
is not present in the primaries, and it will be interesting to note whether that is constant in the Bornean form. The species can readily be separated from A. ace de Nicéville by the broad borders to the primaries and the difference in the pattern beneath. My female from Kina Baln is apparently the only specimen of that sex yet taken.

Arhopala ace de Nicéville.

Arhopala ace de Nicéville, Journ. Bomb. Nat. Hist. Soc. vol. vii. p. 329, pl. H. fig. 13 (1892).

Arrhopele ace de Nicéville and Martin, J. A. S. B. vol. lxiv. pt. 2, p. 461. 1. 390 (1895).

Hal. Perak; sumatra.

Expanse. \& , $46-55 \mathrm{~mm}$.

The female of this species is at present unknown, but the insect is a strongly marked species and can be separated from azinis de $\mathrm{N}$. by the quite different colour of the upperside and by the linear markings beneath.

Arhopala agrata de Nicéville.

Arhopala ayrata de Nicéville, Butt. India, vol, iii. p. 251, frontispiece fig. 13\%, ơ (1890).

Hab. Singapore; Java; Burma.

Expanse, 우, $45 \mathrm{~mm}$.

I have not seen the types of this species, but Mr. de Nicérille has kindly lent his entire collection to me, in which are one specimen from singapore and two from Burma; the types from singapore are in the Raffles Museum at Singapore, which he (Mr. de Nicérille) describes as of the same colour as teesta de Nicév. (i. e. bazalus Hew.); the specimens before me, however, are by no means so deep in hue, being of a more real purple with less of the brown shade; this, of course, may be an individual aberration, but it is advisable to notice it. The underside pattern is somewhat near that of $A$. ace de Nicév, but the transverse band of the primaries is narrow and continuous, whilst in the latter species it is broad and distinctly fractured below the fourth spot; the markings are also very obscure indeed, which is not the case with ace, and the colour of the upperside of the latter is totally different.

ArHopala DETRita (Staudinger).

Amblyporlia detrita Standinger, Iris, vol. ii. p. 122 (1889).

Hab. Palawan.

Expanse, đo, $30 \mathrm{~mm}$.

This species was described by staudinger from an unique specimen, but it appears to be fairly distinct from agrata de Nicév. ; it may be known by its much smaller size, its brighter blue, its broad borders, and beneath by its transverse bands being straighter and in the primaries entirely unfractured. 
Arhopala moxotria (Hewitson). (Plate III. fig. 3, ơ .)

Amblypodia œnotria Hewitson, Ill. Diurn. Lep., Lỵe. p. $14 a$, pl. iii $c$. fig. 56 (1865).

Hab. Philippine Islands; Nias; Borneo.

Expanse, of \& i , 41-4.3 $\mathrm{mm}$.

§. Upperside: both wings brilliant lustrous bluish violet with excessively fine linear black costa, no black posterior margin, the fringes only being blackish. The same is the case with the secondaries, except that the costa is broadly brown and the abdominal fold is brown ; lobe-spot and tail brown, tipped with white. Underside: both wings brown, more or less with a chestnut tinge, with darker spots having pale borders. Primaries with the three usual discal spots, the second and third having each two small spots over them and one below each; transverse chain-like fascia consisting of seven spots, one on the costa. the three next shifted right out, the two below inwards, below which is an indefinite spot varying in size; submarginal row distinct. Secondaries with a spot on the extreme basal edge of the costa, with four basal spots, the lowest shifted beyond the internal nervure, followed by three rather larger spots; cell closed by an almost reniform spot, below which is a small triangular one; chainlike fascia composed of four pairs of spots, the second pair shifted outwards, third inwards, fourth inwards again and confluent; submarginal row distinct, a velvetyblack lobe-spot and another between the second and lower median nervules, each of which is edged above and in the intervening space with bright blue (occasionally green) metallic scales.

ㅇ. Upperside: both wings brown, with a small purplish patch over the discal and central area of the wing, reduced in the secondaries almost to the cell itself. Underside as in the male, but the second and third discal spots are linked together by two spots touching the costal margin of each.

The obliqueness of the first four spots of the transverse band in the primaries varies a good deal, but the species is well marked and easily distinguishable. It has often been confused with agnis Felder, which is a very much larger species.

Arhopala emias (Hewitson). (Plate III. fig. 4, ơ.)

Amblypodia adias Hewitson, Cat. Lycænidæ B.M. p. 6, pl. iv. fig. 36, o (1862); id. Ill. Diuru. Lep., Lye. p. 7 (1865).

Hab. Java.

Expanse, ơ, $51 \mathrm{~mm}$.

0. Upperside: both wings pale, very metallic, lilac-blue; primaries with linear brown costa and finest linear outer margins; secondaries with broad brown costa and very fine linear outer margins; abdominal fold pale brownish grey ; tail black, long, tipped with white. Underside pale chestnut-brown, with darker spots palely encircled. Primaries with three increasing cell-spots, between the second and third of which is 
another spot just orer the cell, and below the third a larger spot in the lower median angle; transrerse band rery distinctly spotted, composed of six spots, first spot small below the costa, second, third, and fourth outwardly oblique and shifted right out from the first, below these two shifted right inwards, but inclined slightly outwards; submarginal row distinct but indefinite; submedian and subdiscal area pale greyish. Secondaries rather darker than primaries, with four small rery dark basal spots, second and fourth shifted inwards, followed by three equally dark spots below each other; cell closed by a large subovate spot, below which is a smaller one in the lower median angle; transverse band very distinctly spotted, composed of eight spots, second separate shifted outwards, third shifted right out again, fourth slightly outwards, fifth well inwards, sixth slightly ontwards, seventh angular spot well inwards, confluent with the long eighth spot; submarginal row distinct, parallel with the outer margin; lobe very slightly developed, with velrety-black spot, and on each side of tail a dark spot with superimposed greenish-metallic scales, which also edge the lobe-spot above.

The beantiful metallic pale colour above will separate this species from any of its allies, together with the very distinctly marked underside. It is a species that does not appear to have been recognised since Hewitson's description, several identifications in collections I have seen being wrong.

Arhopala agis Felder.

Arhopala aymis Felder, Reise Novara, Lep. rol. ii. p. 228 (1865); Staudinger, Ex. Schmett. p. 981 , pl, xeri., of (1888).

Amblypodia agnis Hewitson, 111. Diurn. Lep., Lỵc. p. 14a. n. 74 (1869).

Narathura agnis Distant, Rhop. Malay. p. 262. n. 2, pl. xxi. fig. 29, o (1885).

Amblyporlia anarte Hewitson, Ill. Diurn. Lep., Lỵc. p. 4. n. 8, pl, i. figs. 6, i, $q$ (1863).

Arhopala agnis de Nicéville, Butt. Ind. rol. iii. p. 236 (1890); Druce, P. Z. S. Lond. 1895, p. 589.

Arrhopala agnis de Nicérille and Martin, J. A. S. B. vol. lxiv. pt. 2, p. 466 (1895).

Hab. Burma; Upper Tenasserim; Mergui; Malacca; Perak; Sumatra; Nias; Mindanao; Bomeo.

Expanse, o 55-56, ㅇ 53-64 mm.

The colour of agnis is subject to some rariation; I lave one specimen that is almost blue in tone, and several others very pale mauvy-violet.

This species is easily recognisable from any of the preceding near allies by its much larger size, by the difference in colour of the upperside; the pattern below is very similar, but the difference in tone of colour is very marked.

Arhopala Yendafa (Gr.-Smith).

Amblypodia yendava Grose-Smith, Ann. \& Mag. Nat. Hist. ser. 5, vol. xix. p. 297 (1887); id.

Rhop. Exot, Lycænidæ, pl, xiv. figs. 8 \& 9 ठ, 10 (1898).

Arhopala yendava de Nicéville, Butt. Ind, vol. iii. p. 238 . n. 790 (1890). 
Hab. Burma.

Expanse, of 58, \& $60 \mathrm{~mm}$.

The only difference between the two types of this species and agnis is that the blue in the female is of greater extent than is usual in Felder's insect and that it is paler and bluer, and I have but little doubt that the name shonld be sunk under agnis Felder

Arhopala tameanga Bethune-Baker.

Arhopala tameanga Bethune-Baker and Druce, P. Z. S. Lond, 1896, p. 568, pl. xxix. figs. 7 o, 8 o.

Hab. Tameang-Lajang (S.E. Borneo).

Expanse, of 57 , \& $54 \mathrm{~mm}$.

From agnis Feld. this species may be easily distinguished by the quite different colour of the upperside, which is very dark; the underside pattern is somewhat similar, but the spots of the transverse bands of both wings are more confluent, especially in the secondaries. In rgnis both these fascia are very distinctly spotted. The types are now in my collection.

Arhopala semper Bethuue-Baker.

Arhop ala semperi Bethune-Baker and Druce, P. Z. S. Lond. 1896, p. 659, pl. xxix. figs. 9 ơ, 10 q.

Hab. Borneo (Tameang-Lajang, Kina Balu); Baram River.

Expanse, ot 54, \& $50 \mathrm{~mm}$.

This species is very near tameanga Bethune-Baker, but may be separated by the difference in the colour of the upperside, which is dull riolet, and by the broadish borders; whilst beneath the pattern is similar, but the spots are larger, especially those at the base and the cell-spots. The ground-colour is paler, making the pattern stand out much more prominently. I have, since my first description was written, seen two females from the Baram River (N. Borneo) which I believe to be this species; they are in Mr. Rothschild's Museum, but are very darkly marked. The types are in my collection.

Arhopala barami, n. sp. (Plate III. fig. 5, o .)

Hab. Borneo ; Perak.

Expanse, of \& ㅇ, $50-51 \mathrm{~mm}$.

o. Upperside: both wings purplish blue, in a side light dull and rather dark: primaries with the costa of medium width, dark brown, and a broad outer margin rather wider at the apex; secondaries with a very broad brown costa and rather less broad onter margin; tail brown, tipped with white, of moderate length. Underside: both wings ochreous-brown, with darker spots palely encircled. Primaries with three large increasing cell-spots, below each of which is another, the first two obscure, the 
second being small, the third is dark and large and occupies the lower median angle; transverse band very wide, composed of six spots, the first the smallest, the first four spots being confluent, inclined outwards, with a very slight curve at the fourth, spots 5 and 6 confluent, shifted slightly inwards; submarginal row obscure, marginal row more obscure; submedian and subliscal areas pale. Secondaries with four very distinct basal spots below each other, fourth one shifted well inwards, followed by three largish spots below each other, second one shifted very slightly inwards; cell closed by a large spot, below which is a small one in the lower median angle; transverse band composed of eight spots, the first two large, the second very large and shifted outwards and touching both the spot closing the cell and the third spot which is shitted well outwards, fourth shifted again out, fifth slightly inwards, sixth very slightly outwards, seventh angular spot confluent with the eighth, which is almost bisected, shifted well inwards; submarginal row obscure, a deep black small spot at the anal angle preceded by two other black spots, which are well covered with pale azmre-blue metallic scales, which also edge the anal spot abore.

o. Upperside: both wings paler blue tinged with violet; primarles with a widish brown costa, increasing suddenly just before the end of the cell, where a blackish patch is thus formed invading the blue; outer margin broad, increasing somewhat towards the apex. Secondaries with less broad margins than those of the male. Underside exactly like that of the male.

This species can at once be separated from semperi Bethune-Baker by the purplish colour of the uppersicle, by the broad outer margins, and by the altogether paler tone of the undersice, as also by the pattern being more confluent than that of semperi.

I have before me a male from Perak, in which the outer margins are quite narrow. The male type is in the collection of Mr. Rothschild, and the female in that of the late Mr. de Nicéville, now in the Calcutta Museum.

Arhopala DaJagaKa (Staudinger, MS.).

Arhopale dajagaka Bethune-Baker and Druce, P. Z. s. Lond. 1896, p. 660, pl. xxix. figs, 11 o , 12 \% .

Hab. Kina Balu ; Labuan; Tameang-Lajang.

Expanse, o \& ㅇ, 55-56 mm.

This species may be readily distinguished from semperi mihi by the absence of a tail and by the colour of the underside. which is of a somewhat peculiar greenish brown, and by the isolated spot in the subdiscal area below the second spot in the discoidal cell of the primaries lying about midway between the median nervure and the inner margin. It may equally well be separated from barami mihi by the darker blue of the upperside, the narrow black outer margins, which are decidledly broad in barami, and by the under-surface differences just enmmerated. 
Arhopala axamuta Semper. (Plate III. fig. 6, ơ.)

Arhopala anamuta Semper, Schmett. Philip. Ins. Bd. v. p. 203.

Hab. Mindanao.

Expanse, o, 44-48 mm.

๙. Upperside: both wings dull brownish purple, looking in certain lights quite brown; primaries with narrow black posterior margins and a narrower costa; secondaries with a narrow dark posterior margin and a broad costa; abdominal fold brown. Underside: both wings warm brown, with darker spots palely encircled. Primaries with discal spots; between the second and third is often present on the discoidal nervure another minute spot, and below these two the usual spots are present in the pale internal area; transverse fascia composed of a curved row of six quite confluent spots ending on the lower median nervule, below which is a seventh spot shifted inwards; submarginal row rather indistinct, extreme margin finely dark. Secondaries with a half-spot at the extreme base of the costa; four basal spots inclined inwards, the third being projected outwards, followed by three larger spots; cell closed by a subquadrate spot, below which is a third triangular one connecting it with the lowest of the previous three; transverse chain-band composed of four pairs of confluent spots, the lower of the first pair has its onter margin shifted outwards, the second pair is shifted further outwards, the third pair inwards, the fourth pair consists of the angular seventh shifted inwards and the long eighth spot; submarginal row fairly distinct; a black spot is at the anal angle and between the second and lower median nervule, the space between which is filled with metallicgreen scales, with which the spots thenselves are surmounted; extreme margin finely dark. No tail, but the lower median nervule is elongated into a very short tooth-like projection, decidedly shorter than in dajayaka.

This species is a close ally of rajagaka Stgr., but is easily distinguished by the uniformly broad and regular transverse band on the underside of the primaries. I have also a small-sized specimen of a much brighter blue, with no brown shading at all.

Arhopala allata (Staudinger). (Plate III. fig. 7, $\delta^{*}$.)

Amblypodia allata Stgr. Iris, vol. ii. p. 125, Taf. ii. fig. 1 (1889). Arhopala allata Druce, Proc. Zool. Soc. Lond. 1895, p. 590.

Hab. Palawan, Mindanao, and Mindoro; Labuan.

Expanse, o 41-45, 우 $42-44 \mathrm{~mm}$.

๙. Upperside: both wings very dark, dull, almost brownish violet, in some lights looking almost brown; primaries with broad blackish posterior margins and narrow costa; secondaries with very broad dark brown margins all round; tail tipped with 
white. Inderside: both wings chestnut-brown, with darker spots with pale encirclings. Primaries with three discal spots; below the second and third is another spot, the second in the paler submedian area, that below the third at the angle of the lower median nervale; the transverse baul composed of five confluent spots, almost straight, but slightly inclined outwards: heneath this, under the lower median nervule, is sometimes a very minute dot; submarginal row somewhat indistinct, extreme margin excessively fine dark brown. Sccondaries with four basal spots, the second and fourth shifted inwarels, followed by three larger spots in a straight line below each other; cell closed by a long narrow spot, below which is a very small one in the lower median angle; transverse land composed of two upper detached spots, the second shifted outwards, four confluent spots shifterl right outwards, the lower two of which are each slightly shifted inwards, seventh and eighth spots quite confluent, the angular seventh being shifted well inwards: submarginal row fairly distinct, the upper white margin of which reaches the internal nervure; anal spot black, and a black dash is between the lower and second median nervules, the space between and above which is filled with motallic bluish-green scales.

9 . Upperside: both wings dull bluish purple, brownish purple in certain lights. Primaries with rery broat posterior and apical brown margins and a broad brown (usta. Secondaries with very broad margins all round, in fact the purple only occupying an area a little beyond the discoidal cell. Underside like that of male, but in the transverse band in the secontaries the thirt of the confluent spots is shifted decidedly inwarels; this is constant in the five females before me.

The late 1)r. Staulinger most kindly lent me his two original types of this species, which were figured in the 'Iris,' rol. ii. pl. ii. fig. I, of but there must have been a mistake' with this figure, for it does not agree with the type f'male, nor yet with any female I possess, neither with any male. There is no spot beneath the lower median nervale of the transverse band in the primaries, and in the secondiaries the two upper spots of the transverse band are quite detached and are distinct and well defined, not confluent and almost obliterated as in the figure. The spots and markings are also much sharper than the figure would lead one to suppose. The only sperimen from Mindoro is bright almost ultramarine-blue, not dull purplish as usual. The peculiar colour of the upperside, brownish violet, will separate this species firom any of its neighbours.

Arhopala kHamti Doherty.

Ailopala likemti Doherty, J. A. S. B. vol. 1., pt. 2., p. 32, pl. i. fig. 5, of (1891).

Ilab. Margherita, Upper Assam.

I have not been able to see this species, but from the description it is evidently near wrea 11 ew.

vol. XVII.-PART I. No. 17.-Lugust, 190:3. 
Arhorala GNe.1 (Hewitson). (Plite V. figs. 21 \& 21 a.)

Amblypodia anea Hewitson, Mll. Dimrn. Lep., Lye. p. 11.e, pl. iii $c$. fig. 55 (I869).

Arhopale anea de Nicéville, Butt. Ind. vol. iii. p. 213 (1890).

llub. Siklim; Khasia Hills.

Expanse, of \& o, 41-44 mm.

This species is local, but not nncommon where it occurs; it may be readily distingnished from its neighbours by its brighter colomr, larger size, and the clear, clean-looking ochre-brown of the under surface. 'The genitalia bave the tegumen excavated and open at the apex, and the looks, jointed at the elbow, are from that point long and slender; the clasps are very deep, excavated at the tips, forming a sort of jaw, the upper part of which is resolved into a long, curved, sharp hook. The penis is long and slruder.

Arhopala rama (Kollar). (Plate V. figs. 22 \& $22 \%$.)

Theclu rame Kollar, Hü̈grl's Kaschmir, vol. iv. pt. 2, p. 112. n. T, pl. iv. figs. 1, 2, 万( (1818).

Amblypodie rame liewitson, Cat. Lyeenide B.M. p. 13. 11. 59, pl. vii. figs. 69, 70 o, 71 o

(I\&6.2) ; Lecch, Traus. Ent. Soc. Lond. 1889, p. 111. n.51.

Panchala rama Moore, Proe. Zool. Soe. Lond. 1882, p. 252 ; Doherty, Joum. A. S. B. vol. Iv.

jt. 2, p. 126. 11. 122 (1856); Butler, Aun. \& Mag. Nat. Ilist. ser. (5, vol. i. p. 145. n. 38 (1888).

Amblypodin querceti Noore; Horsficld and Moore, ('at. Lep. Mius. E.1.C. rol. i. p. H3. n. (j. (185i).

Arleopala rana de Nicéville, Butt. Int. vol. iii. p. 251 (I890).

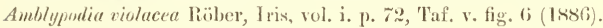

Ilab. IIimalayas; Bmma; China; Sikkim.

Expanse, of 3j, क $33-35 \mathrm{~mm}$.

IIerr Röber has described his violacfa, from " the Last Indies," as a distinct species, but it agrees in every respect with this insect-there is not one small point in which 1 can differentiate it. It may be known from rener Hew. by the broadish onter margins, by the pale colonr of the underside, by the tail being little more than a long tooth, and by the absence of an anal black spot and any metallic scaling.

The exceedingiy broad dark margins of the secondaries are also a marked characteristic of the species. The genitalia are not mnlike those of renea liew., but the tegumen-hooks are short and not elbowed; the clasps are broader, with the upper part of the jaw pointed but broader. The penis is decidedly stouter.

Arhopali atrax (Hewitson). (Plate 1II. fig. 8, o .)

Amblypodia atrex IIewitson, Cat. Lye. B.M. p. 13. 11.58 (nec pl, vii. figs. 80 \& 89. f) (1862)

Noore, Proc. Zaol. Soe. Lond. 1865, p. Trt; ffewitson, Ill. Dimrn. Lep., Lyc. p. 13 (1869).

Satalra atrax Moore, J. A. S. B. vol. liii. pt. 2, p. 39 (1881).

Arhopalu atrux de Nicéville, Butt. India, vol. iii. p. 2140 (1890). 
Hah. India (ilistribution unknown to me); Tavoy Valley; Burma.

Fixpanse, \& \& $8,42 \mathrm{~mm}$.

: (type). Upperside: both winese rather bright purplish bluc, shull in a side light; primaries with a narrow black costa and broad posterior margin ; secondaries with a spot (n) each side of the tail, which is black, rather long. tipped with white. Underside pale brown, washed with pale pinkish lilac, with darker spots palely cilged. I'rimaries with three increasing cell-spots, the first and second of a narrow-ovil shaje ; below the second and third are two spots divided by the lower median nervule; tonching the tip of the imer edge of the third cell-spot is another one on the elge of the cell; on the costa are two small spots. one over the third and the other narer the second cell-spot; transverse band composed of seven spots dislocated below the fourth, first spot small, second larger, shifted outwards, third inwarels, fourth outwards, fifth well inwards, sixth slightly out, seventh slightly inwards but with an ontward inclination; submarginel row narrow, rather obscure; submedian area pale. Sccomilurics with four small basal spots, secoud and fourth shified inwards, followed by three larger ones below each other, the second of which is shifted inwards; a large snbruatrate spot closes the cell, below which is a small one in the lower median angle, where it joins the lowest of the series of three spots; transwerse band composed of eight spots, the second very large and shifted slightly oitwarels ats to its outer margin, but well inwarels as to its imner margin, where it touches the spot closing the cell, thirel sput shifted woll ontwark, fourth further ont, fitth inwarls, sixth outwards, seventh ingular spot shifted right inwards and touching the eighth spot (this transrerse band his the appearance of a bifurcated band owing to the second spot tonching the cell-spot, which is joined to the two spots below, as described); submarginal row very obscure; lobe-spot blackish (lobe scarcely developed), ant a small blackish spot just beyomet the tail well covered with pale bronzy-green scales, which fill up the space between it and the lobe-spot, and also edge the latter one.

क. Upperside: both wiugs bright rather pale blue, darker in a side light; primaries with very broat costa, bruater beyond the cell, outer margins very broarl; secondaries with very broad costa and rather less broad outer margin. Under surface exactly as in the male, but the spots are rather larger.

In describing this insect Ifewitson, as he intimates, confused two quite distinct species; fortmately his type male is preserved in the National collection, and it is distinct from the female in the Hewitson Collection. Colonel bingham has given a pair to the Museum which he captured in Burma (Tavoy Valley) in March I893, so that $1 \mathrm{am}$ thus enabled to describe the true female. My description of the male is from the original type. The female described with the male by Hewitson is entirely distinct, and I have therefore re-named and re-described it with its correct male under the nane hewitsoni. 
Arhopala hewitsoni n. sp. (Plate III. fig. 9, o; Plate V. figs. 23 \& 23 a.)

Hab. India; base of Himalayas from Dehra Dun to Bhutan; Malda and Chota Nagpur Districts; Central Provinces; Calentta; Orissa; Nilgiris ; Burma.

Expanse, ơ 35, ㅇ $38 \mathrm{~mm}$.

๙. Upperside: primaries dull like, with costa narrowly dark brown, and a very dark brown posterior margin. Secondaries darkish brown, with a lilac-blue patch situated just orer the discoidal cell. Tail brown, white-tipped. Underside pale greyish brown, with a somewhat shining pale lilac tinge, spots darker, palely encircled. Primaries with three small discal spots increasing in sizc; beneath the second and third are two spots separated by the lower median nervule, and on the costa, a little forward of the third, is another small one; transverse fascia continuous, gently arehed; fifth and sixth spots inwardly inclined, seventh spot detached and obscure; submarginal row obscure but dark, and followed by a darker shading up to the margin; submedian area paler. Secoudaries more tinged with lilac, with four very small dark basal spots, the fourth paler and obseure and shifted inwards, followed by three small spots, the upper two dark, the lowest paler and obsenre; cell closed by a larger spot, below which is a small triangular one; transverse fascia-spots-first and second almost confluent, the second rather the larger, the third and fourth confluent and shifted right ontwards though not quite detached, fifth shifted inwards, sixth outwards, seventh shifted well inwards, detached from the eighth, which is small and really forms a fourth lowest spot beneath the three middle ones; submarginal band darker, and followed by a darker shading up to the margin; a very dark spot on the lobe, followed by a scanty scattering of greyish seales mixed with a few metallic-bluish ones on the margin almost to the second median nervure.

․ Upperside: both wings brown: primaries with a darker patch at the apex of the cell, and a largish brighter lilac-blue patch occupying the discal, central, and submerian areas, but not below the submedian nervure; secondaries uniform brown. Underside as in the male, but spots and fascia a little more distinct.

'This species has hitherto passed as $A$. atiax Hewitson. 'That author described two distinct species under that name. The male being described first, as nsual, the name of atrax must attach to it, Hewitson's type of which is in the National collection. The female described by IJewitson is this species, both sexes of which are now quite common, and are mentioned and re-described by de Nicéville in his 'Butterties of India' (vol. iii. p. 246). The colour of the upperside alone easily separates it from atrax, which latter is very decidedly brighter and blucr than the present species, which is of a very obscnre violet colour. 'The genitalia do not call for special remark, and are figured on Plate V. figs. $23 \& 23 a$. 
Arhorala alemon de Nicéville. (Plate $V$. figs. 24 \& 2 4 a.)

Arhoprala alemon de Nicéville, Joum. Bomb. Nat. Hist. Soc. p. :371, pl. F. figs. 201 o , :21 of (1891),

IIn). Burma.

Expause, \& 40, \& $16 \mathrm{~mm}$.

De Nicéville likens this species to A. rmma Kollar, but it is a much eloser ally of A. hewitioni mihi; iudecd the males are difficult to separate; ulemon is somewhat larger, with the violet colour rither more sulducd, slightly more extensive and indefinite as to its onter margins; the females arc, howerer, more easily separated, being very much larger, with the whitish patch pupilled with black elosing the cell, whilst helow the ground-colour is without any violet tinge, decidedly paler than A. hemitioni, the spots comseruently showing proportionately darker.

I have at present seen only this species from Burma, where it probably replaces A. hevitsoni in certain districts. 'The genitalia are slighter in proportion than those of the previous species, the hooks are longer, and the clasps smaller. The penis is neirly straight.

Irhopala canalatca (Mogre).

Satadra cunareica Noore, Journ. A. S. B. vol. liii. pt. 2, p. 39 (1881); Waterhouse, 1id, pl. elxv. figs. $5,5 u, \delta(1886)$,

Arliopale canaraica de Nicérille, Butt. India, vol. iii. p. ‥5. 1. 799 (1890).

Ilub. ('anara, S. India (Hoore); Travancore (de Nicrille).

Expanse, of $40-45$, f $44-45 \mathrm{~mm}$.

This speeies is somewhat near alemou de $\mathrm{N}$., but can le easily separated by the lihe colour of the upperside and by the purplish tinge of the brown of the under surface, which is also decidedly darker than in alemon; the pattern is likewise smaller and darker.

Armop.ala alda (Hewitsin).

Amblypodin alea Hewitson, Cat. Lycienida B.M. p. 1:. 11, 5\%, pl. vii. figs. $79,81, \delta$ (1862). Situder alea Mloore, J. A. S. B. vol. liii. pt. 2, p. 38 (3884).

Arhopulu aleu de Nicéville, Butt. Ind. vol. iii. p, :214; (18990).

Ilab. India.

"Male. Upperside: both wings violet-blue; fore wing with the outer margin rather broad. Hind wing with the margins as broad as in the females of other species. Underside: both wings brown, tinted with lilac. Fore wing with the transverse hand long and narrow, slightly curved. Hind wing with the baud broken, ill-defined; the anal angle irrorated with white." (Ilewitson, l. c.)

This species Hewitson described from a specimen in the National Collection which 
is now lost, there being no insect in the Mnseum that at all agrees with Hewitson's figure. I possess one very close, but the transverse band of the secondaries is not absolutely broken, as shown in his figure.

Ariopala dodonea (Moore). (Plate V. figs. 25 \& $25 a$.)

Amblypodin dodonea Moore; Horsfield and Moore, Cat. Lep. Mus. E.I.C. vol. i. p. 43. n. 65, pl. i $a$. fig. 8 (1857).

Panchala dodonea Moore, Proc. Zool. Soc. Lond. 1882, p. 252.

Panchele dodoncea Butler, Amm. \& Mag. Nat. Hist, ser, 6, vol, i. p. 144. 1. 37 (1888).

Panchala? dodonee Butler, Proc. Zool, Soe. Lond. 1886, p. 364. n. 32.

Arhopala dodoncea de Nicéville, Butt. Ind. vol. iii. p. 258 (1890).

Hal. Western Himalayas.

Expanse, of \& i , 40-48 mm.

This is a very distinct species, easily recognisable from all others; both sexes are exactly alike. It is perhaps nearest $\mathcal{A}$. rema Kollar, bnt the very pale, almost silvery, blue, and the extremely broad borders of the upper surface separate it easily, whilst below it is quite different, being very pale, with the markings standing prominently ont, the pattern heing very similar. Mr. de Nicéville (l.c.) thought this might be a dimorphic form of rama. I have, however, examined several males and mounted dissections of the genitalia, which show. I think, that the species are quite distinet, though very close. It will be seen that the claspers differ somewhat, and all the organs are very much larger and stouter.

Armopala comica de Nicéville.

Arlopala comicu de Nicéville, Journ. Bomb. Nat. 11 ist. Soc. vol. xiii. p. 170 (1900).

Hab. Live Lomg, near Bhamo, Upper Burma (5000 feet).

Expanse $43 \mathrm{~mm}$.

When describing this species from a single example, de Nicéville himselt says it may be an aberration, but that he is at a loss to conjectnre of what species. I have no donbt whatever that it is a sport of A.durlonea Moore. The shapes of the tail and of the lobe are almost identical ; the outline of the wing is very similar. The colour of the wings above, together with the denticulate invasion of the blue patch, at once remind one of Moore's inseet, whilst below the around-colom is very close in hue, and though the spots are aberrant, the general line of pattern is similar. This is an instance of the undesirability of describing a species from an unique example.

Aritopala Japonica (Murray). (Plate 11l. fig. I0, *; P'late IV. figs. 2̇l \& 21 a.)

Lycena japonica Murray, Lint. Mo. Mag. vol. xi. p. $16 z$ (18r t).

llab. Japan.

Expanse, of \& ㅇ , 45-47 mm. 
In both sexes the apex of the primaries is produced into a short hook tip.

This species is somewhat near puremutu de N., but may easily be recognised by the paler and brighter lilue, the cell being closed by a black spot on the npperside of the primaries, and by its larger size, whilst the colour of the under surface is much smonther aud rather more uniform. The genitalia are very close to those of $A$. irema and dodonea, with the penis strongly bent near the oritice. The clasps are, howerer, broader, and the lateral supports of the tegumen straighter.

Ariopala parameta (de Nicrivile). (Plite IV. figs, 22 \& 2.2 a.)

I'anchalu? puranutu de Nicéville, Journ. A. S. B. vol. liii. pt. :2, p. 81. n. 23, pt. ix. ligs. $\sigma$ o, ; $a$ \& (1883).

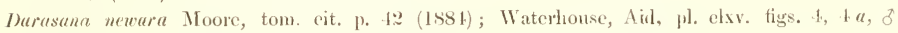
(1886).

A hehopala parameta de Nicérille, Butt. 1nul. vol. iii. p. 298 (1890).

llub. Nepal; Nikkim; Lhasia llills.

Expanse, of \& o, :34-36 $\mathrm{mm}$.

1). Nicriville says $(l, r)$ this is a common species in Sikkim, occurring in April and Vay. It is very easily separated from those near it, being a very distinct little species. The genitalia are distinct, having a compact heary tegumen, with short, nearly straight hooks; the clasps are just the shape of a ham cut off sharply at the kunckic end. The penis is nearly straight.

A Hilopala zeta (Moore).

Amblypodin zeta XLoore, Proe. Zool. Soe. Lond. 187\%, p. 590, pl. lviii. fig. 6, $q$.

Satudra zeta Hoore, J. A. S. B. vol. liii. jt. 2, p. 11 (18st).

Arhopalu zeta Moore; de Nicéville, Butt. India, vol. iii. p. 268 (1890).

Ilab. S. Andaman 1sles.

Expranse, 오, $31 \mathrm{~mm}$.

ㅇ. Upperside: both wings hrilliant pale blue; primaries with costa broally black up to apex of cell, where it suddenly increases in width up to the apex, onter margin very broadly black; secondaries with very broad margins all romd. Under side: both wings warm cimmamon-brown, with darker spots palely encircled. Primaries with three increasing cell-spots, below the third another spot in the lower median angle; transverse band composed of five (? six) spots; both wings have been injurcd here, and it is not possible to say whether there is a small spot on the costa or not; spots confluent, the first three forming a very slight arc. and the fourth and fifth having a slight inward tendency, submarginal and marginal rows olsenre; subliscal area darker, snbmedian paler, than the ground-colour. Secondaries with four small basal spots, the third shifted slightly outwards, followed by four larger spots below each 
other; cell closed by a larger spot, below which is a small one in the lower median angle; above the spot elosing the cell are two spots above each other, reaching to the costal nervure; these usually form the first two of the transverse band, which band is shifted slightly ontwards, the second spot is shifted slightly out, the third inwards, fourth ontwards, fifth inwards, the band being composed of only five spots ; snbmarginal and marginal rows fairly definite, no spots or metallic scaling at the anal angle.

Mr. Moore has very kindly lent his type specimen (unique) to me, from which this description is taken. I have more to say abont it under the next species.

Ariopala roona (Moore).

Narather roona Moore, J. A. S. B. vol. liii. pt. 2, p. 12 (1884).

Arhopala roona Moore; de Nicéville, Butt. lndia, vol. iii. p. 268 (1890).

Ilab. Andaman Isles.

Expanse, of \& i , $33-39 \mathrm{~mm}$.

o \& $\&$. Uppersile: both wings rather bright violet-blue; primaries with costa broadly blackish up to the apex of the cell, where it sudilenly increases up to the apex of the wing, onter margin very broad; secondaries with broad margins all round. Inderside exactly like zito Moore, except that the colour is paler and the markings larger, and also that in the secondaries the two spots usually forming the first two spots of the transverse band are just attached to the rest of the band; in the type of zeta they are detached. There is no trace of the usual dark anal spots or metallic sealing.

De Nicéville has very correctly diagnosed these two species. I keep them apart with great rehctance: the blue of the upperside is, however, quite distinct, being quite pale, almost silvery and lustrous in zetu; in roona it is quite violet. The specimen of zrtu has, however, a somewhat crippled appearance, and is decidedly smaller, and it gives me the impression of the larva having been starved. If this is so it is not at all unlikely that the colour is abnormal. Recent material has bronght to our hands more roona from the Andaman Isles and also from Burma, but no zeta have come. I feel that they are probahly one and the same species, but in the absence of snfficient material I refrain from definitely miting them.

Arhopala agelastus (Hewitson).

fmblypodia agelustus Hewitson, Cat. Lye. B.M. p. 12, pl. vi. figs. 61 \& 62, \& (1862:).

Nurathure agelustus Moore, Journ. Linn. Soe. London, Zool. vol, xxi. p. H. (1Ksti).

A.hopala agelastus de Nicéville (in parte), Butt. India, vol. iii. p. 278 (18:90).

IIab. India; Mergni ; Burma.

Expanse, o , $47 \mathrm{~mm}$.

๙. Upperside: both wings rather bright dark purplish blue; primaries with eosta narrowly black, slightly increasing towards the apex, posterior margin rapidly decreasing 
towards the anal angle, apical area very broadly black; secouderies with it bread costa and rather narrow posterior margin. Tnder surface ochre-brown. with darker markings palely but faintly encircled. Primaries with three small increasing cell-spots, below the third a small one in the lower molian angle; transverse band composed of six eonfluent spots, with a very slight curve in the three upper ones, the whole band being slightly oblique outwards; submarginal and marginal row obseure; submedian area pale; subdiscal area dark. Seeondiries with four, guite small, basal spots, the fourth shifted well inwards, followed by three larger ones heluw eafl other, the second shifted slightly inwards, and the third the liargest of the three ; cell closed by a subreniform spot, below which is a rery small one in the lower median angle; over the spot closing the coll are two others (usually forming the two upper spots of the transserse hand) above each other, the lower our being the larger; transverse baud componed of sis spots begiming on the upler discoidal nervule, the first two conftuent, the second shifted very slightly outwards, third with the inner marein only shifted inwarls, fourth almost contluent with the thirel, fifth angular spot touching the sixth ant shified well inwards; submarginal and marginal row obscure; a small black spot at the amal angle, preceded by two others, which are nere or less covered with pals greenish-blur metallic spots.

Ahopula perissa Dolnexty is a very elose ally of this speeies; in fiact, I am extremely doubtful if they are not one and the same, but as I have so little material I deem it best to keep them distinct for the present. Woherty's speeies has the spots and finscia wider and larger, and the borders of the upperside broader.

1). Nicéville says (Butt. Ind. l. (.) that Mr. Doherty slowerl him certain specimens taken at Meraui and in T'enasserim, and that some of them bore traces of a circular patch of differently shacled seales on the upperside of the fore wing, as in A atosin Hewitson. I have these specimens now before me, named ugelestus by de Niceville; but they are moolaiana Moore, and not Hewitson's speciens: the reference to atosia should therefore be eliminated from the accomnt of ayelastus in de Niceville's work.

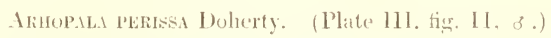

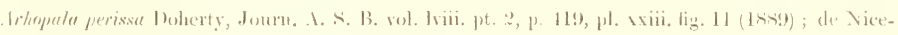
ville. Butt. Indiat, vol. iii. p. 22\% 8 . 11. $812(1890)$.

/lab. Vyitta; Tenasserim Valley; Burma.

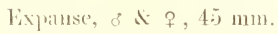

'There appear to loe two forms of this species, dhffering on the mplersite only; the

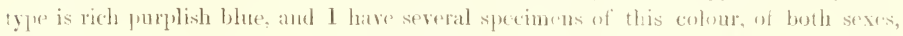
hefore me, but 1 have also in de Nicéville's series sereral of both sexes which are brilliant gale lustrous blue, withent any ardmixture of purple at all ; the underside is precisely the same in every respect. I notice the same thing in foungure (ir.-. Smith, but the difference is by no means so market.

Vol. XHIL-PALT I. No. 1s.-Angust, 1903. 
This species is an exceedingly close ally of tounguve Gr.-Smith, but as I lave only seen about a dozen of each species, I have thought it better to keep them distinct. It is quite possible, however, that further material may prove them to belong to one and the same insect; in fact I believe this will prove to be so. They obtain in almost exactly the same district; both are local, this species being only recorded from Burma, and tounguva from Burma and the Andaman Isles.

Arhopala tounguva (Gr.-Smith). (Plate III. fig. 12, * .)

Amblypodia tomnyura Grose-Smith, Am. \& Mag. Nat. Hist. scr. 5, rol. xx. p. 268 (1887).

Arhopala tounyuva de Nieéville, Butt. India, vol. iii. p. 269. 11. 830 (1890); (Grose-Smith, Rhop.

Exot., Lyc. pt. H, pl. xr. figs. 1, 5 (1898).

Ilab. Toungu; Burma; Andanian Isles.

Expanse, of \& ㅇ , 44-47 mm.

In some specimens the undersile is irrorated slightly with ochreous, whilst the upperside is occasionally of a violet-blue. Both sexes are almost the same. The markings of the underside are very close to perissa Doh., and also to asopia Hew.; from the former it can be distingnished by the difference in the transverse band of the secondaries, and also by the colour of perissa being clear, smooth, cinnamon-brown beneath, whilst tounguva has more or less of an irrorated or dusted appearance.

Asopia Hew. is sufficiently distinct not to require differentiating. As mentioned moder the previous species, I believe that tounguve will prove to be one and the same as Doherty's insect.

Arhopala asopta (Hewitson). (Plate HII. tig. 13, ơ.)

Amblypodia asopia Hewitson, 11l. Diurn. Lep., Lyc. p. 11.f. 110. 90, 1l. iii c. figs. 50, 51 (1869). Irhopale asopia de Nicéville, Butt. Ind. vol. iii. p. 270 (1890).

Hab. Moulmein, Upper Tenasserim, Tilin Yaw, and Bhamo (N. Burma).

Expanse, o \& ㅇ, 46-48 mm.

o. Upperside: both wings dull sublustrous violet, rather dull in tone; primaries with the costa narrowly, posterior margin broadly, apex more broadly dark brown; secondaries with costa broadly, and posterior margin less broadly brown; abdominal margin greyish. Underside: both wings cimnamon-brown, with darker spots palely encircled. Primaries with spots darker than secondaries, and tinged with violet; three discal spots, below which the submedian area is dark, below the third spot is another arljoining it ; transverse band very regular and even in width, widish, slightly curved near the custa, and with a slight outward inclination; below the submedian nervure is an obscure spot beneath the band; submarginal band dark, but obscure; submedian area pale. Secondaries with spots paler than in primaries, one on the costal base, four basal spots, the upper two very small and dark, followed by four larger ones; cell 
closed by an elongated spot, below which is a small triangnlar one; two spots from the costa below each other, of which the lower one is slightly oblique and touches both the elongated spot and the npper one of the transwerse hand, which begins on the upper discoidal nervure and extends beyond the submedian; the second spot, rectangular like the first, is shifted slightly ontwards, the inner margin of the third is shifted inwards, fourth spot outwards, fifth right inwarls, not detacherl, and confluent with the small sixth; submarginal row very obscure; the lower median nervure is slightly clongated, so as to form a short tooth-like projection.

q. Upperside: both wings bright blue; primaries with costa broally, outer margins more broadly, and apical area still more broadly blackish; secondaries with hroadish borders all round, but decreasing towards the anal angle, the costa being the bruadest. Inderside as in the male.

I have one female from Tilin Iaw ( $\mathrm{N}$. Burma) before me in which the colour of the upper surface is exactly of the same violet tint as in the male, not bright blue as usual. In de Niciville's fine collection I find several specimens of this insect, and it is from these that I am enabled to add Tenasserim and Tilin law to its distribution, whilst Haberhauer took a female in Bhamo, which is in I)r. Standinger's collection now before me. It is evilently a rare and local species, but is uot difficult to separate from its near neighbours by the pale violet colour, and also by the mderside being very decidedly paler than any of its allies. It should be easily recognised from the figure (Plate. III. fig. I\%, os).

Arhopala geta de Niciville.

Arhopala reeta de Nicéville, Journ. Bombay Nat. Hist. Soc. vol. vii. p. 333. n. 10, pl. II. fig. 17, o (1892).

Hicl). Bumm:

Expanse, ㅇ, $43 \mathrm{~mm}$.

I cannot help regarding this as merely an aberration of asopir Hew.; the whole appearance of the specimen bears this out. In a difficult genus like this, where the species are so closely related and are separable by such small characteristics, it would be a wise plan never to describe a species from a unique example (as in this case) unless it should happen to be a palpably new and strongly marked insect.

dimopala perimuta (Mome).

Amblypodia perimute Moore; Horsfickl and Noore, ('at. Lep. Mus. li.I.C. vol. i. p. 42. n. 61

(185\%) ; Ilewitson, (at. Lycienide B.M. p. 1:. 11. 55, pl. vi. figs. 65, 66, of (1862) ; id. Ill.

Dium. Lep., Suppl. p. 2I. n. 62, pl, vii. suppl. fig. 61, of (18\%

Darasema perimuta Moore, Journ. A. S. B. vol. hiii. pt. :, p. 4: (1884); it. Jomrn. Limn. Soet

Lond., Zool. vol, si. p. 14 (1886).

Arhopalu perimuta de Nicrville, Butt. Ind. vol. iii. p. $270(1890)$. 
Itul. Sikkim; Sylhet; Khasia Ulills; Cherra Punji, Margaree; Pegu; Burma; Nergui.

Expanse, o $30-32$, ㅇ $29-30 \mathrm{~mm}$.

This species en be easily recognised from asopir IIew. by its much smaller size and its blue (olour (asopia being quite violet in tonc), whilst the quite tifferent colour leneath, yellow and pmolish, will at once separate it. 'The genitalia lave the tegmmen short and of a heary scimitar-shape; the clasps are bilobed, and the penis is a straight tube.

Amiopala azenti (Hewitsom).

Amblyporlia azenia Hewitson, 13l. Dium. Lep., Lye. p. 7, pl. iii. figs. 22, 23 (1865).

1Iwb. New Guinea.

Expanse, of 44-52, of 4 (i-48 mm.

This very beantiful species has heen exceedingly rine mutil within the last few year, but recent collections from New (iuinea have contained considerable numbers. It has been somewhat difficult to give it and the following species ( $A$. ncron Hew.) their right position; but the latter is evidently near to admete Hew, so this will be their best position, though the brilliance of the blue of azenin Hew. at first makes it look out of place.

There is no difficulty in recognising the species at a glance, the lustrous almost morpho-like blue of the upperside, and the beantiful white underside just tinged with faintest pink, beneath which the nsual spots and bands (nearly allied in position to those obtaining in admete) show through as a sort of purplish-lilac colour, should make the insect distinguishable at once. It is a beatiful species, but apparently with about the most limited range of distribution in the group.

Armopala ackon (Hewitson). (Plate III. fig. 14, o.)

Amblypodia acron Hewitson, Cat. Lyc. B.M. p. 9, pl. v. Higs. 53 \& 5 t. (186:2); id. Ill. Dium. Lep., Lye. p. 7 (1865).

Hal. Batchian.

Expanse, of \& $9,46 \mathrm{~mm}$.

This insect is a close ally of the preceding species, but can be distinguished at once in that the blue colour of the upperside is decidedly durker, whilst beneatli the colour is uniform greyish brown, with the spots and bands a trifle darker, outlined sharply with fine whitish edgings. It is, I believe, a very rare species; I have only seen about lualf a dozen examples in all the collections that have passed throngh my hands, and tne of those is in my own collection. Though Hewitson's figure of the underside is not good, it is quite sufficient to enable the species to be recognized. Neither this nor the preceding species is likely to be confused easily with other species. I can trace no records of this butterfly elsewhere than from batchian. 
AHHOPALA ADMETE (Hewitson).

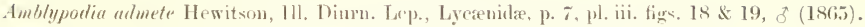

Amblyporlia encolpris Kirseh, Mitth. 1. k. zool. Mos. Dresden, Helt ii. Tat'. vi. fier. 6; Ribbe, lris, vol. ii. p. $257(18999)$.

Arhopela admete (irose-Śmith, Norit. Zool. vol. i. p. ist (15!)1).

Ilal. Il:almaheina : Ceram; (iilolo: Now (iminea .

Rixpanse, * \& $P, 44-i 0 \mathrm{~mm}$.

This species is at once separable from its noar allies ly its large size and by its molerside pittern, which in the primaries is marked by the absence of any spot in the cell (I have specinens in which the least trace of ome is just discernible), the first spot being that closing the ecoll, and hy the broad dark transverse band, whilst in the secondarios the main chameteristic is the very white efleing (generally more or less suffused in the male) to the transverse band.

Its distribution is somewhat confined and local, it boing at present only recordeal from Ceram, Gilolo, IIalmaheira, and New Ginineas.

Var. Walieolssis, nov. var. (Plate III. fig. 15, o .)

*. Upperside: both wings bright rich lustrous blue, rather dark, but not at all lull, as in admete, but much brighter. Underside similar to admete in the markings of both wings, but the ground-colour quite pale; the apical area of the primaries is tinged broadly with pale lilac; the secondaries are entirely tinged with very pale pinkish lilac, and the white external suftission to the transverse band is rery broal indeed, forming a most marked character. The spots and markings are fully as dark as in admete, and therefore stand ont very prominently in the pale wround.

ㅇ. Upperside: both wing very much paler and greener in tint, with the median nerrules in the secondaries broadly black. Underside as in the male, but the tint of the secondarjes is more pinkish ochreous, not shining, and there is no broad white suffusion to the transverse band. There is a trace of a small and obscure spot in the centre of the cell of the primaries, both in this variety occasionally and also sometimes in admete. 'This variety forms a sort of link between eprimete and admete.

Ilal). Waigeoe.

Expanse, o $37-40$, क $33-3.5 \mathrm{~mm}$.

I have three nates and two females of this very pretty form from the island of Thaigeoe, where 1 expect it replaces admete Hew.

Ariopala Epimete (Staudinger). (Plate III. fig. 16.)

Amblypodia rpimete Standinger, lris, vol. ii. p. 128, pl. ii. tig. 2, 3 (1859).

Jlab. Palawan.

Expanse, o $\mathrm{d}+34-35 \mathrm{~mm}$.

๙. Tpperside: primaries violet-blue, with costa broally, posterior margin rery broadly. 
and apical area more broadly still, purplish brown; secondaries dark brown, with an obscure blue patch occupying the cell or thereabouts; no tail. Underside: both wings pale ochreous brown, tinged with pinkish; spots and fascia darker, margined with whitish. Primaries with three increasing discal spots, beneath and above the third another spot, that above being close on the costa, subdiscal space up, to the lower median branch dark; transierse band composed of six laterally margined spots ending on the lower median nervule: the first spot on the costa is small, second shifted well outwards is larger, thiri with its imer margin only shifted a little inwards, fourth large spot shifted well ontwards and oblique (these spots are sharply margined and form a slight irregular curre), fifth and sixth spots are indefinite somewhat as to their margins, and the sixth is shifted outwards from the iffth; below this is usually another very indefinite and obscure spot, not reaching quite to the submedian nervule, and not always present. Secondaries more pinkish than the primaries, with four basal spots, the third shifted slightly outwards, followed by four larger spots and occupying equivalent positions; cell closed by an irregular spot, below which is another small one touching the third spot of the previons row above, and tomching the spot closing the cell are two others, the upper of which is shifted outwards: transverse band begimning on the upper discoidal nervule and composed of six small spots, the second shifted well outwards, but inclined inwards, the third right inwards, fonrth ontwards, fifth right inwards, the sixth very small, slightly inwards; these with the lowest of the two rows of four spots form an irregular imer half-circle round the lobe, posterior and abdominal margins; submarginal row as usual, the anal portion of which is broadly margined internally with greyish; margin obscurely and darkly spotted; the usual submarginal row followed by a slight darker marginal spotting; apical area slightly dusted with greyish; submedian area from the transverse band pale.

i. Exactly like the male. except that the obscure blue patch in the secondaries is almost absent.

This is apparently a rare insect, and at present is only recorded from the island of Palawan; it is rather near admete, var, waineoensis, but may be separated by its smaller size, its more violet colour, which is very much less extensive in the primaries and is almost absent in the secondaries, whilst beneath it is more uniform in tone and pattern and is much more spotted.

Arhopala bejphebe Doherty.

A.liopala belphabe Doherty, J. A. S. B. vol. lviii. pt. 2. p. 421, pl. xxxiii. fig. 18 (1889); de Nicéville, Butt. India, vol. iii. p. 2r:2 (1890).

Ilab. Myitta; Tenasserim Valley; Burma.

Expanse $8 \mathrm{~mm}$.

T have not seen this insect, but from the figure and description it evidently belongs 
to this section. The resemblance to "agfrsins" I cannot quite follow, as that is a rery different-looking and strongly-marked species.

Arimesta derisi Moherty.

trhopala duesset Doherty, Journ. 1. S. 13. vol. 1viii. pt. :2, p. 119, pl. xxiii. tig. 6 (1889); de Niceville, Butt. Ind. vol. iii. p. 2\% (1890).

Mlıl. Myitta; Dannat Range; Tenasserim.

Expanse $36-3 . \mathrm{mm}$.

This species is near cpimete stgr., but the brilliancy of the blue of the upperside will at once separate it from that insect. The underside of Standinger's species is so dose to this that I believe the one is probably a local form of the other.

Arhopal. ammoxides (Doherty). (Plate III. fig. 31, o*.)

Acesinu ammonides Duhcrty, J. 1. S. B. vol. 1.. pt. 2, p. 31. 1. 5 (1\$9(9).

Itrth. Tenasserim.

Expanse, d $80-31 \mathrm{~mm}$.

'This species is rery close to duesse Doh. in the colour of its upperside, but is paler, and it has at tail. which durser has not; beneath it is deeper in general tone, whilst the light parts are whiter, and it has the marked whitish spot on the costa of the secondaries. It forms an excellent link from the tailless group we have just bcen comsidering with the tailed group named by Moore Acesina. I do not sece my way, however, to retain this genus, as the characters given are quite inconstant in the various species that should form the subgenus, and would aplly cqually well to others widely separated from these.

Arhopala amaro: (Hewitson).

Amblypodia ammon Hewitson, Cat. Lycienidie B.M. 1.9. 1. 1.1, pl. v. figs, 19, 50, $\neq(186: 2)$.

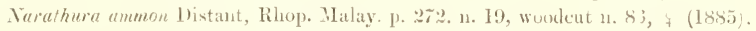

Arhopala ammon de Nicéville, Butt. Ind, vol. iii. 1. 2.1:3 (1890).

Arhopale nmmon it. Niciville and Martin, J. A. S. B. vol. lxiv, pt. 2, p. fro (1595).

lleh. Malacca; Sumatra.

Fixpanse, of \& $8,320.30 \mathrm{~mm}$.

This species maty be (anily separated fiom ammonides 1)oh. by the lilac tonte and the narrow borders of the primaries, and also by the uniform colon of the under surface.

Arilopala MYKZaL. Hewitson.

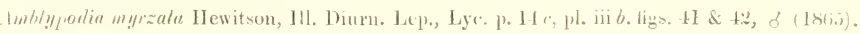

1lab. Nindanao; Philippine Islinds.

Kxpanse, o \& $\&$, $4.2 \mathrm{~mm}$. 
This species, from its size and general appearance, looks scarcely in keeping with its near neiglabours, being about half as large again, but the underside pattern is so very similar that I cannot place it elsewhere; it may at once be recognised by its large size.

Arhopala birmana (Moore).

Panchala birmanu Noore, Proe. Zool. Soe. Lond. 1883, p. 531.

Achopala birmana de Nicriville, Butt. Ind. vol. iii. p. 227 (1890).

Acesinu arisbe de Nicéville, Journ. Bomb. Nat. Hist. Soe, vol. vi. p. 369 (1891).

Arhopala birmana Grose-Smith, Rhop. Exot., Lye. pt. 1t, pl, xr. figs. 1, 2, 3 (1898).

IInb. Toungu; Burma; Tenasserim.

Expanse, of $37-40$, ㅇ $32-40 \mathrm{~mm}$.

The with of the border's is variable. Specimens from Tilin Yaw (13urma) have the borders decidedly wider than those from Tenasserim, but in all cases they are much wider than in aberans de N.; the blue is also darker and the size decidedly smaller. From paraganesa de N. it may be distinguished by its larger size, its darker and very much more extensive blue. I lave the type specimens now before me, and they agree precisely with those of arisba de Niceiville.

Referring to the original descriptions of this speeies, I have not been able to examine the genitalia of them, but I have no doubt in my own mind that the specimen with the white spot, describerl as a male, is the female, and that the one with the darker and larger blue area is the male which was described as the female; the same remark also applies to both the text and the plate in Mr. Grose-Smith's 'Rhopalocera Exotica.'

Alinopala abelilians (de Nicéville).

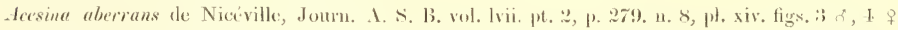

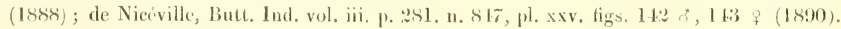

Hub. Upler Tenasserim; Tilin Jaw (N. Burma).

Expanse, of \& $8.40-44$ mm.

This species on the upperside is very distinct, but on the undersicle it is alnost an exact copy of permfenese te $\mathrm{N}$., only very much larger. It is also latger than birmene Noore, and of a much paler ani rather brighter bhe, whilst the female has a very marked patch of white at the upper extremity of the cell of the primaries.

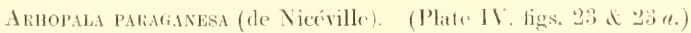

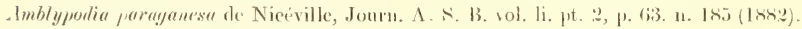

Panchale parayanesa Hoore, Proe. Zool. Soc. Lend. 1883, p. 530. 
Acesina farayanesa Moore, Jomrn. A. S. B. vol. liii. pt. :. p. 1:2 (1s81); de Niciville, Butt. Ind. vol. iii. p. 281. 11. \& 46 (1890).

Hhb. Northern India; Nepal; Sikkin; Assam; Jilva (Gerle) (Fruhstorfer).

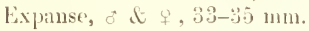

This species has, I believe, been litherto confined to Xorth-eastern India, but recently Herr Fruhstorfer, of Berlin, has sent me some specimens of Arhopula to determine, among which is a single male of this species taken on Gede Mountain in Java; it is not, however, a typical specimen, the unlerside being more like ammonides in colour and general appenrance-it is, however, most probably this species. 'The genitalia are quite typical of the genus Ahopalı, with the clasps rather larger than usual: the penis is bent in the middle.

ARHopal. zephyietta (Doherty).

Aresina zephyretta Doherty, I. 1. S. B. vol. 1. pt. 2, p. 33. n. 3 (1891).

Helb. Nargherita: Upuer Issan; Cherra Punji.

Expanse, of of $\div, 30 \mathrm{~mm}$.

at . Upherside: both wings dirk brown; primaries only with a very small diffused patch of pale blue extending but little over the cell. Under surface with the markings just like parrengese de Niceville, but the general tone is much more uniform without the strong white contrasts usually present in that species.

This is probably only a local form of de Nicciville's species.

Arhopata ariel (1)oherty). (Plate III, fig. 24, ơ .)

Aresine ariel Doherty, .J. A. S. 13. vol. 1x. pt. :2, p. 333. n. 1 (1891).

IIah. Vargherita; Upler Assam; Klasia Ilills; Cherra Punji.

Expanse, \& 31 , $35 \mathrm{~mm}$.

ठ. Upperside: both wings very deep lustrous bluish purple; primaries with the purple colour having a strong, oval, well-defined onter margin, leaving the apex and the anal angle exceedingly broadly black, the outer margin less broadly so, and the costa up to the end of the cell rather narrowly black; in the secondaries the purple has the same oval onter margin, but only extends to just beyond the cell. T'ail blackish, tipped with white; fringes dark, with scarcely a trace of light edging. Underside: both wings dark brown tinged with purple, with a slight lilac dusting. Primaries with the purple tinge eonfined to the costa and outer margin and the lilac dusting to the apex; all the spots are precisely as in paragancsu do $X$., with the exception of the forrth spot of the transserse hand which is shifted strongly outwarks, and there is but little white on the interior of this band. Secondaries with all the markings precisely as in paraganesa de $\mathrm{X}$., but the ground is very dark, strongly tinger all over with purple, with a slight lilac dusting especially near the apex, and a prominent white spot between the two outer spots on the costa.

vol. XVil.-PakT I. No. 1!-duyust, 1903. 
ㅇ. Uppersitle: both wings black; primaries with a very small, pale blue, basal area ; secondaries with the leats trace of a pale blue dusting elose to the base, very much less in each case than in puruganesu de $\mathrm{N}$. Underside: both wings darkish brown, with a slight violet tint and no lilac dusting; otherwise just like the male.

This species is quite distinct from paragunes de $\mathrm{N}$. ; the upperside is quite different, being very much darkes blue, whilst the secondaries have a very much less extent of blue; beneath it is fairly miform in tone, with very little white indeed, almost confined to the costal spot of the secondaries.

Arhopala ginesa (Moore). (l'late 1V. figs. 24 \& 24 a.)

Amblypodia yanesa Moore; Horsfield and Moore, Cat. Lep. Mus. E.I.C. vol. i. p. 4t. n. 66, pl. i $u$. fig. $9(1857)$.

Panchala ganesa Moure, Proc. Zool. Soc. Lond. 1882, p. 252; Doherty, Journ. A. S. B. vol. iv. pt. 2, p. 126. n. 121 (I886).

Arhopala ganesa Staudinger, Ex. Schmett. p. 281, pl. xevi., ơ (1888); de Nicéville, Butt. Ind. vol. iii. p. 28:2 (1890).

Ilab. Western Himalayas.

Expanse, of of, 28-31 mm.

This species may be recognised from all its neighbours by the entire paleness of the underside of the secondaries; the primaries are also very much paler than any of its allies. The underside pattern is close to this subgroup of the genus, to which it is more nearly related than to dudonea Moore, near which it has usually been placed.

1)e Nicrivile says (l. c.) it appears to be confined to an altitude of 5500 to 6500 feet in forests. It has a wide range, occurring in Kashmir on the west to Kumaon on the east, always in oak-forests, where it is rather common.

The genitalia are similar to those of praraganesa de N., but the clasps are of a different shape, and the curve of the penis is nearer the base.

Arhorala loomisi Pryer.

Arhopala loomisi Pryer, Rhop. Nih. p. 11, pl, ii. fig. 15 (1886).

Arliopala yanesa var. scminiyra Lcech, Eutomologist, xxiii. p. 4.

Arhopala ganesa var. loomisi Pryer; Leech, Butt. China, pt. ii. p. 3-13, pl. xxx. fig. 11 (1893).

Mub. Japan; ('bang-yang (Central China); Chow-pin-sa (Westeru ('hina).

Expanse $82 \mathrm{~mm}$.

"Male. Primaries blne, paler beyond the cell ; costa and outer margin deeply bordered with black; the discoilal spot, which is within the costal borler, is more intensely black. Secondaries black, suffined with blue, most pronounced along the central area. Fringes fuscons grey. Under surface (primaries) pale brownish grey, with four whitish wavy-edged darker bands, the first two are basal, the third is abbreviated, the fonrth hroar and the only one which is clearly defined; subnarginal line slender and 
interrupted: secondaries greyish brown, with four intermpted hambs these are of the gromml-colonr, but darker at the ciges, and bordered with whitish; brownish submarginal line wavy, bordered with whitish, and followed by a few hrownish lincal dots on the margin; finges pale grey, preceded loy a darker line. Expanso 320 mm.

"- It the time I described the abose form of $A$. grenest, I wat not acyuainted with Pryer's loomisi; I now find that the latter and my var. seminigne are identical; as, however, Pryer's name is the carlier one, it must stand for the Japanese and Chinese form of the Indian A. genese. The type lomisi was taken at Kanozan, in Kadnoa, Japan; I received one example from Chang-yang, Central China, and another from Chow-pin-sa, Western China."-Leech, l. c.

I have not seen a specimen of this insect.

Arhopala arvixi (Hewitsom).

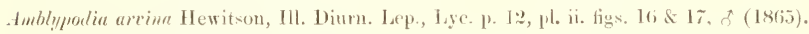

Arhopala aboe de Nicéville, Journ. Bomb. Nat. Hist. Soc. vol, ix, p. 281, pl. O. tig. 266, J (1<95).

Hab. Java, Assam, Tentasserim.

Expanse, o,, $39 \mathrm{~mm}$.

s. Upperside: both wings intense ultramarine-blue; primaries with very fine black margins; secondaries with the costa broadly, posterior margin very finely black, abdominal fold blackish. Underside: both wings brown, suffused with lustrous purplisli, entirely as to the secondaries, but only as to the uppre two-thirds in the primaries; spots browner, with paler purplish edgings. Primaries with three discal increasing spots, the first two obscure, below which the submedian area is darker, below the third there is another spot; transverse band of moderately even width, ontwardly oblique for the first four spots, followed by two spots below each other, shifted inwards; the band continuous, a small detached spot beneath the band is below the submedian nervule; snbmarginal lumular row rather obscure, followed by a marginal interrupted narrow band. Secondaries entirely purpish with resldislı spots, four near the base, followed by three rather larger ones; cell closed by an elongated curved spot, below which is a triangular one; on the costa are two spots below each other, the lower one being much larger than the first and touching both the elongated spot and the upper spot of the transverse band, which comsists of three pairs of spots, each pair being quite confluent, the second pair is shifted inwards, the third pair well inwards, the latter spot of which is almost divided into two and tonches the internal nervure; submarginal row lumular, but rather indefinite. No tail.

ᄋ. Upperside: both wings pale sublustrous azure-blue; primaries with a broad brown costa, very broad outer margin, and yet broader apical area; secoudaries with very broad margins all round, the costa being the broadest. Undersile like the male, but much paler and not so rich in colour; pattern just the same, but inclined to be rather obscure. 
The male of this species is a benutiful inseet, the intense riehness and depth of the blue being very striking. I have one specimen from Java, in which the reddish purple of the underside is entirely replaced by a curious subdued steely bronzy green, something like the colour occasionally found in meunter Boisd.

In de Nićville's collection are two males and one female from Tenasserim, and in Staudinger's collection there is one male from Assam.

The female has not hitherto been described, but Herr Fruhstorfer has sent me a tine pair from Java for identification and 1 have described the female sent by him.

Arhopala adala de Nicéville.

Arhopala adala de Nicéville and A. adulans de Nicéville, Journ. Bomb. Nat. Hist. Soc. vol. ix. pp. 28:2-281, pl. O. figs. $27 \& 28$ 万, 29 q (1895).

Hab. Dannat Range and Ataran Valley; Tenasserim; Burma.

Expanse, of 43-44, \& 44-46 mm.

I have very earefully examined this speeies and compared it most particularly with 1. adulans deseribed by de Nicéville at the same time. and I cannot believe that they are other than one and the same speeies. The main differences stated by him are that the latter is darker and less reddish, and lacks the small costal spot over and beyond the third eell-spot. Now I find that in all species that have a reddish, or a reddish tinged with lilac or violet, underside, the colom is very liable to vary, and except in very fresh specimens the lilac or violet colour is apt to evanesee and leave a merely reddish hue behind; then as to the laek of the costal spot, in one of de Nicéville's specimens of alala there is a very small spot present on the costa of one wing, and 1 have noticed in this group of inseets that this particular spot seems given to oecasional disappearance.

This species is very close indeed to arvinu Hew., and will come next to it, indeed so close is it that on first examination 1 quite thought it was the female of that speeies, but eloser inspection revealed that some of the specimens were males.

Arhopal. BLDDHa, n. sp. (Plate IIl. fig. 25, o.)

Hab. Java.

Expanse $40 \mathrm{~mm}$.

6. Upperside: both wings pale azure-blue; primaries with a broad black costa, broader outer margin, and yet broader apical area ; secondaries with very broad margins all round, the costa being rather the broadest. Tail short, fairly stout, tipped witl white; at the end of the cell in the primaries is a distinct black spot invaling the blue. Benenth both wings fairly dark purplish lilic, with rather darker spots tinged with red. The pattern is just the same as in alcla de Nicérille, exeept that there is a distinct bend in the first four spets of the transverse band of the primaries and a very slight fracture below the fourth spot; there is also a slight trace of some submetallic scales at the anal angle. 
I have described this species from an example taken by Iterr Fruhtorter on Gede Mountain in Western Java at an altitude of about 4000 foet.

ArHOPALA C.EL (Hewitson).

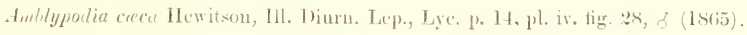

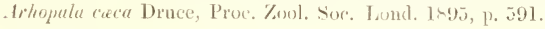

Hab. Bomen.

Lixpanse, * \& $90-12 \mathrm{~mm}$.

o. Upperside: both wings submetallic violet-lilac, in a side light more distinctly lilacine; primaries with exceedingly fine linear brownish margins; secondaries with the costa broadly brownish and the posterior linear margin exceedingly fine. Underside: both wings brown, with a somewhat bronzy lustre, with darker spots and fascice palely edged. Primaries with a minute spot beyond the centre of the cell, which is closed by a larger one; transverse fascia oblique and curved, ending on the lower median nervure, this fascia is quite broad at its end but tapers upward to a very narrow line at the costa ; submarginal row very obscure; subdiscal area dark, two semi-confluent small dots are beneath the origin of the lower median nervile; subunedian area very slightly paler. Sccondaries with all markings much darker, fonr very minute somewhat indistinct basal dots, followed by three spots below ench other, the upper two being very small indeed, the lower one lituger; cell closed by an elongated good-sized spot, from which up to the costa runs an equally broad straight stripe shifted slightly outwards and also slightly outwardly oblique; transverse band from the upper discoidal to the internal nervere composed of two very small spots, the third spot is larger and slifted inwards, fourth larger still and shifted outwards, fith right inwards and confluent with the long sixth spot; anal angle with a small dark dot followed by a very slight brilliant green-metallic scaling, orer which is an irregular whitish stripe. 'lail short, very stout, blackish, tipped with white; fringes scalloped with white on each side of the tail.

T. Upperside: both wing purplish blue; primaries with a blackish spot closing the cell and a broad black costa, yet broader onter margin, and broader still apical area; secondaries with extremely broad margins all round, the costa being the broadest. Underside like that of the male.

This species is entirely distinct from any others that I know and atpears to be contined to the island of Borneo.

Arllopala candua (Hewitson). (Plate IlI. tig. 26, . .) Amilypodia canulia Hewitson, Ill. Diurn. Lep., Lyc. p. 1+f. n. 91, pl. iii a. figr. it, o (1869).

Hab. Philippines; Batchian.

Expanse, \& $\&, 37-39 \mathrm{~mm}$.

o. Upperside: both wings deep purplish, with very fine black linear margins; in the 
secondaries the costa is broad. Underside: both wings brownish grey. Primaries with a narrow, even, obscure, transverse band to the lower median nervule; submarginat band larker and broadish at the anal amgle, tapering away below the apex. Secondaries with an obscure narrow spot elosing the cell and another obscure one below the cell; transverse band distinct, moderately even, lightly edged interiorly, but the outer pater edging diffused; submarginal row obseure, palely edged in the anal area; it small black spot at the anal angle, a larger one between the second and lower median nervule, the space between and orer which is very pale bluish white.

f. Upperside : primaries blackish, with a paler and less purple-blue patch from the discoidal to the submedian nervule and abont a third over the median area. The secondaries are bluish from the upper diseoidal to the submedian nervure with a broad dark margin, all the nervures showing broally black. Underside as in the male, but with all the markings very much obscured.

This is a very distinct species and is recognisable at a glance; it is very near fulle Hewitson, the distinctions being recorded under that insect.

Arhopala fulal (Hewitson).

Amblypodia fulla Hewitson, Cat. Lycetnidie B.M. p. 10. 11. 17, 13. vi. figs. 67, 68, o (186:2); Hewitson, Ill. Diuru. Lep., Lyc, p. 11 (1865).

Hab. Boiron; Andamans; Amboina.

Expanse, o 37, o $36 \mathrm{~mm}$.

๙. Upperside: both wings brilliant shining riolet-blue; the primaries with an exceedingly narrow black costa and narrow black posterior margin; sccondaries with the costa broadly and the posterior margin narrowly black, abdominal fold greyish, a slight tooth-like projection at the end of the lower median nervule. Underside: both wings pale, slightly rufous brown. Primaries paler in the submedian area, spotless, with a narrow transverse band to the lower median nervule somewhat obscure; submarginal and marginal areas rather darker. Secondaries with an exceedingly obscure spot in the cell and a very narrow dash closing it; beyond this a broadish band of darker shading edged indefinitely rather palely, the exterior edging broadly pale; marginal and submarginal areas darker, divided at the anal angle by a pale curved line; a very small black dot at the extreme anal angle.

f. Upperside: both wings paler and less violet than in the male; primaries with costa and posterior margin broadly and apex very broadly blackish; secondaries with costa very broadly and posterior margin narrowly black. Underside as in the male.

'This species may be known from canulin Hewitson by the bluer and brighter colour of the npper surface and by the darker, redker, and warmer tone of the under surface. Camlia has a very cold greyish under surface and has also distinct black anal spots with metallic scaling, which are absent in this species. 
Alimopata (andananiea) W.-M. \& de N. (Plate IV. figs. 25 \& 25 a.)

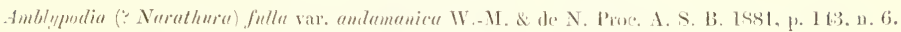
Nuruthure sulfefesciate Moore, Trans. Ent. Sise. Tond. 1s81, p. 31:..

Arhopula andamanica de N. Butt. 1udia, vol. iii. p. 267, pl. xxvii. fig. 199, (1890).

Ilel). Andamans.

Expanse $40 \mathrm{~mm}$.

c. Upperside: both wings bluer than in 1 . fulla Hew., and with less violet in it; the costa and posterior margin more broadly and the apex much more broadly black in the primaries; the costa is also shorter, the apex sharper, and the posterior margin ronnder than in fullu Hew. Underside as in A. fullu, but ochreons instear of shightly rufors.

?. Upperside: both wings paler and bluer than in the male; primaries with a broal black costa, very broad onter margin, and very much broader apical area; secondaries with a very broal dark costa and rather narrow onter margin.

This species is quite listinct from fullt IIew., and is a mnch smaller insect. The genitalia have the tegumen-hooks stontish and the clasps are heavy and broad, terminating in short uptmmer points.

Arhop.la whoti Miskin. (Plate I. figs. 18 o, 19 \%.)

A.hopale wildei Niskin, Ann. Qneensl. Mns. no. 1, p. zl (1891).

Amblypodiet cupido standinger, in litt.

IIal. Queensland.

Expanse $44-45 \mathrm{~mm}$.

6. Upperside: both wings suhlnstrous azure-blne of a ronghish texture, with narow black costa to the primaries and wide onter maroins increasing towards the anal angle; secondaries with broad dark greyish costa, white above the costal nervure, and wide black onter margins increasing at the anal angle; tail black, tipped with white; abdominal fold pale greyish. Underside: both wings white with brown spots and fascia. Primaries with costa broadly brown, extending between the discal spots, which thus show a white margin; two spots in the cell and one closing it, beyond which are three very oblique (ontwarlly) spots, forming a short very oblique row from the third subcostal nervule; submarginal row very distinct at the anal angle, tapering finely into obscurity at the apex; submarginal band continuous. Secondaries with three basal spots followed by three rather larger ones below eacil other; submarginal row distinct and Inmulated; margin pale brown, moderateiy broad, lomnlated as to its imner edge; extreme margin finely white; at the anal angle is a black spot, a very slightly metallic marginal dusting is between the lower aml submediun nervures.

\%. Uppersile: both wings dark brown. with a large suow-white patch in the 
primaries extending orer the discal, submedian, and two-thirds of the median areas. In the secondaries the white patch is confined by the upper discoidal and submedian nervures and is not in the cell, except at its outer extremity, where it is closed by a dark spot. At the base of both wings there is a bright pale azure-blne scaling, extending half over the cell and more than halfway along the inner margin of the primaries, but almost confined to the cell in the secondaries. Tail brown, tipped with white.

This is a very distinct species and should be recognisable without the least difficulty.

1). Siandinger sent me one female with his collection, and I found three males in the Tring Mnsem, these being all the specimens I have seen.

Arhopala disparalis (Felder).

Amblypodia disparalis Felder, Sitz. Akad. Wiss. Wien, xl. p. 54 (1860); Hewitson, Ill. Diurn. Lep., Lyr. p. 1?, pl. iv. fig. 25, $\delta$ (1865).

Arluopala disparalis Felder, Reise Nov., Lep. p. 230. n. 256, tab. xxviii. figs. 4 \& 5.

Amllypodia coutrvoisieri Rible, Iris, vol. xiii. p. 335, Taf. vi. fig. 2, o (1901).

Hab. Amboina; Coram.

Expranse. of $43 \mathrm{~mm}$.

c. Upperside: both wings pale silvery blue not lustrous, with a lilac shade in a side light; primaries with a fine dark costa and rather wider outer margin; secondaries with a greyish costa not very broal, posterior margin narrow; tails black, whitetipped. Underside: primaries greyish white, becoming greyish brown on the outer margin, with no markings at all except a trace of a submarginal band; the subdiscal area is darker grey. Secondaries whitish, with a dark grey spot closing the cell; transverse band composed of eight dark grey isclated spots, with the exception that the seventh and eighth tonch each other; submarginal and marginal rows distinct, the latter fine; a dark spot on each side of the tail.

․ Upperside: both wings white, with very broad borders all round. Underside like that of the male.

This species is near wildei Miskin, but is smaller, with narrower borders, rather different colour, and darkish grey beneath, not white, whilst the spots are also different.

The specits described under the name courvoisieri by libbe (l.c.) is withont doubt Felder's insect.

Alimopala chitala (Felder).

Amlilypodia critala Felder, Lep. Amboin., Sitz. Akad. Wiss. Wicn, xl. p. 453 (1860); Ilewitson, Cat. Iyye. B.Ml. no. 67, p. 15 (1862); id. 11l. Diurn. Lep., Lye, p. 9, pl. iv. tigs, 26,27 (1865). Arlopula critala Standinger, Exot. Selnuett, p. 281 (1888).

Ilab. Amboina.

Expanse, ơ 48, f $46 \mathrm{~mm}$.

o. Upperside: primaries excedingly pale azure-blue, with white showing through 
in the median area; costa and posterior margin very broally dark brown; the onter margin of the blue is very strongly scalloped. Secondaries with extreme base dark brown, followed by a rery broad band of white, extending aleng the costa to beyond the subcostal nerrure and all down the abdominal fold; the rest of the wing to the margin is very dark blackish brown ; the cell and about a quarter bevond it and the submedian area for a like distance are exceedingly pale azure-blue; tail dark brown, margin strongly scalloped on each side of it, tipped with white, each of the nervure-spaces from the anal angle to the npper median nervure has a broadish submarginal dash of very pale whitish blne, with which colour the fringes of both wings are tipped. Underside: primaries with the cell, the costa, and the posterior margin very broarly dark brown, the rest of the wing forming a large triangular white area. Secomdaries, a broul dash of brown at the extreme base, followed by a very broad transverse band of white; rest of wing to posterior margin dark brown; from the intemal to lower discoidal nervure is an exceedingly broad marginal band of very pale metallic greenish blue intermpter ly the nervures, between each of which is a long black spot in the blne.

f. Upperside: like that of the male, but with no blue whatever, the blue area of the primaries being white; the margins are also broader. There is a trace of a very scanty blue scaling at the base of the primaries. Undersile as in the male.

This is an instance of the very rare case of mimicry in this gromp, the species mimicking the genus Danais very beautifully.

Arlopala aхютthen (Hewitson).

Amllypodia axiothea Hewitson, HI. Diurn, Lep., Lyc. p. 7. 11. 2T, pl. ii. figs. M) \& 11, o (1865).

Amblyporlia strophe Grose-Sinith, Novit. Zool. vol. iv. p. 366 (1897); il. Rhop. Exot., Lycenide, pl. xiv. figs. 6 \& $\approx$ (I898).

Mah. New Guinea (Ilewitson); Kapauu, Dntch s.W. New Guinea (Gir.-Smith).

Expanse $46 \mathrm{~mm}$.

This species is like no other of the group; the broad and peculiar fascia of the underside will separate it immediately from every other species. 

PLATE I.

X - 


\section{PLA'TE I.}

Fig. 1. Mahathale heinene, o+, n. sp., p. 23.

‥ Iraota lazarene, ㅇ, p. 13.

3. Surentre amisena, o, 1. 6.

4. ", ", type + , p. 6 .

5. " " $"$ blue \&, p. 6 .

6. ., vivarna, type o, P. 6.

7. Arhopala viola, o, p. 51.

8. ," dohertyi, o, n. sp., p. 64 .

$9 . \quad, \quad$ hereules, var. hereulina, o, p. 28.

10. . kiriwinit, of, n. sp.. p. 38 .

11. ", expolis, o, p. 41.

12. ", padus, क. p. 46.

13. ", " blue o, p. 46 .

14. " erilomes, o, p. 49.

15. " tephlis, type o, p. 53.

16. " " of, from C'elebes, p. 53 .

17. " bazaloides, ơ, 1. 55.

18. " wildei, o, p. 151.

19. , , क, p. 151 .

20. " sengire, o , p. 57.

21. " helius, o, p. 58 .

22. " " var. anthelius, o, p. 58.

$23 . \quad$ "2. myrtha, o , p. 61.

24. ", mindanensis, ơ, n. sp., p. 6.'.

25. ", myrtule, o, 1. 63.

26. ", quercoiles, o, p. 68 .

27. " phanops, o, p. $6 \mathrm{~s}$.

2.S. " ijanensis, o, p. 80 .

29. ", brookei, of, p. 84.

30. $\quad$ psendomuto, o, p. 87. 
PLATE II. 


\section{PLATE 11.}

Fig. 1. Arhopala vihaide, of , p. 66

$$
\begin{aligned}
& \text { 2. ", malayict, o, P. } 71 \text {. } \\
& \text { 3. , nicévillei, o, p. } 73 . \\
& \text { 4. "nobilis, of, P. } 74 \text {. } \\
& \text { 5. , , }, \text { ю, } 7 \text {. } 74 \text {. } \\
& \text { 6. ," moolaiana, o, p. 89. } \\
& \text { 7. ", amphimuta, o, p. } 90 . \\
& \text { 8. " inoinutu, of, p. } 91 . \\
& \text { 9. " "pimut", of, p. } 88 . \\
& \text { 10. ,, "gersilnus, o, p. 93. } \\
& \text { 11. „, catori, 8, p. 93. } \\
& \text { 12. " denceana, o, p. } 96 . \\
& \text { 13. , yunongensis, o, p. 97. } \\
& \text { 14. " hrehme, oे, p. } 99 . \\
& \text { 15. „, hypomente, of, p. } 99 . \\
& \text { 16. , olserthuri, o, p. } 101 . \\
& \text { 17. " alonias, of, P. 10:. } \\
& \text { 18. . irregularis, o, p. } 111 . \\
& \text { 19. „, enmolphus, o, ex Darjecling, p. } 104 . \\
& \text { ๖0. , , „, ex Java, p. } 104 . \\
& 21 . \quad, \quad \text {, }, \text {, ex Khasia Hills, p. } 104 .
\end{aligned}
$$

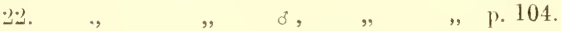

$$
\begin{aligned}
& \text { 23. ,, , क, type form, ex Sikkim, p. } 104 \\
& \text { 24. " " } \quad \text { q, pale blue, ex Palawan, p. } 104 . \\
& \text { 25. „2 staudingeri, of, p. 109. } \\
& \text { 26. " horstieldi, o, p. } 107 . \\
& 27 . \quad, \quad \text { basiviridis, of, p. } 108 . \\
& \text { 28. ", liuhni, o, p. 11:. } \\
& \text { 29. } \because \quad \text {, क, p. } 113 . \\
& \text { 30. , morphina, o, p. } 117 .
\end{aligned}
$$


PLATE III. 


\section{PLATE III.}

Fig. 1. Arhopale chinensis, of, p. 118.

2., corinda, ơ, p. 121.

$3 . \quad$ anotrin, o*, 1. 124 .

4. " adias, o, p. 124.

5. " berami, of, p. 126.

6. ", anamute, o*, p. 128.

7. , allata, o, p. 128 .

S. ., $\quad \operatorname{atrax}$, o , p. 130 .

$9 . \quad$, hewitsoni, of, p. 132.

10. " japonica, oै, p. 134

11., perissu, of, p. 137 .

12. " tounguva, ơ , p. 188.

13. " asopia, o, p. 138.

14. ", acron, of, p. 140.

15. ., admete, var. waigeoensis, of, P. $1+1$.

16. $"$ equimete, o, p. 141.

18. , artes, oै, p. 45.

19.,$\quad$ "numle, o, p. 76 .

20. , , , के var., p. 76 .

21. , ,,$\quad$, pale blue var., p. 76 .

22. " axone, o, p. 35 .

23. ", auxesia, o, p. 80.

24. " ariel, ơ, p. 145.

25. „ Ineddha, o, n. sp., p. 148.

26.,$\quad$ canulia, of, p. 149 .

27.,$\quad$ argesias, o , p. 95 .

28. " hesla, o , p. 95.

29. ,, viola, type \&, p. 51.

30 . , , var. ㅇ, p. 51 .

31. ", ammonides, of, p. 143. 
PLATE IV.

VOL. XVII.-PART I. No. 21.-Angust, 1903. 


\section{PLATE IV.}

Fig. 1. Surendra amiseure. genitalia profile; $1 a$, penis: p. 6.

2. Ircotu timoleon, . ", , $\quad 2 a, \quad ., \quad$ p. 9.

3. Amblypodia made, ", , $3 a, \quad, \quad$ p. 16.

4. Mahathala remeriu. ,. " $44, \quad, \quad$ p. 22.

5. Thaduka multicaudata, genitalia profile: $5 \mu$, penis : p. 24 .

6. Arhopalo hermes, $\quad, . \quad$, $\quad 6 a, \quad, \quad$ p. 28 .

7. " plitander, " , $, \quad 7 \mu, \quad . \quad$ p. 30 .

s. " mermer, " " " s", , p. 32 .

9. " amytis, " " , 9 " $4, \quad, \quad$ p. 33.

10. " $\quad$ centamus, $, \quad, \quad 10 \alpha, \quad, \quad$ p. 39.

11. " amantes, " " $111, \quad, \quad$ p. 42.

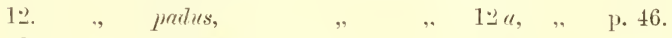

13. ., erilanus, $\quad, \quad$., $13 \pi, \quad$, p. 49.

14. " tephlis, " " 14 ", , p. 53.

15. " buzqloides, $, \quad, \quad 15 u, \quad, \quad$ p. 55 .

16. " $\quad$ mmulate, $, \quad, 16 \alpha, \quad, \quad$ p. $5 \%$.

17. " "thelue, ", " 17 ", , p. 56.

18. " "nthore, " " $18 a, \quad$, p. 58 .

19. " alitiens, " " $, 19 a, \quad, \quad$ p. 61 .

20. " dohertyi, $\quad, \quad$, $20 \%, \quad, \quad$ p. 64 .

21. " jifronicr, ", "21", , , p. 134.

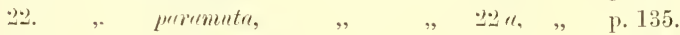

23. " parayenesa, " " $\quad 23 a, \quad, \quad$ p. 144.

24. " $\quad$ yanesa, $\quad, \quad$, $24 \mu, \quad, \quad$ p. 146.

25. " andamanica, " , , $25 a, \quad, \quad$ p. 151 . 
PLATE V. 


\section{PLATE V.}

Fig. 1. Arhopala alce, genitalia profile; 1 ", penis : p. 76 .

2.,$\quad$ amuda, genitalia profile ; $2 a$, penis : p. 76 .

3. " $\quad$ aroa, $, \quad, \quad 3 a, \quad, \quad$ p. 85 .

4. " $\quad$ elopura, , , $, \quad 4 a, \quad, \quad$ p. 86 .

5. " atosia, $, \quad, 5 \pi, \quad, \quad$ p. 87 .

6. " epimuta, ", " $6 a, \quad, \quad$ p. 88 .

7. ", agesilaus, , $\quad, \quad 7$ ", , p. 93.

8. " catori, " $, \quad 8 a, \quad, \quad$ p. 93.

9. " agesias, , " $\quad 9 \%, \quad, \quad$ p. 95 .

10. " moorei, ", " $10 a, \quad, \quad$ p. 97.

11. ", deva, " , $11 a, \quad, \quad$ p. 98 .

12. " metamuta, genitalia profile; $12 a$, penis: p. 100 .

13. " muta, " " $13 a$, , p. 101 .

14. " exmolphirs, , , $\quad 14 a$, , p. 104 .

15. " basiviridis, ", ,. 15 ", , p. 108.

16. " diarli, ", $, 161, \quad, \quad$ p. 113.

17. , "prilans, " , $17 a$, , p. 11 5.

18. " adrimu, " , $\quad 18 a, \quad, \quad$ p. 117.

19. " chinensis, " " $\quad 19 a, \quad, \quad$ p. 118 .

20. " single,,.$\quad$ " $20 \%$, " p. 120 .

21. " "nea, , , $211, \quad, \quad$ p. 130 .

2.2. " "rma, " " $, 22 ", \quad, \quad$ p. 130

23. " hewitsoni, , , , $23 a, \quad, \quad$ p. 132.

24. " alemon, " ,, $24 a$, , p. 133.

25. " $\quad$ dodonea, , " $25 \alpha, \quad, \quad$ p. 134. 


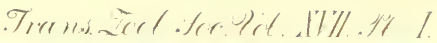
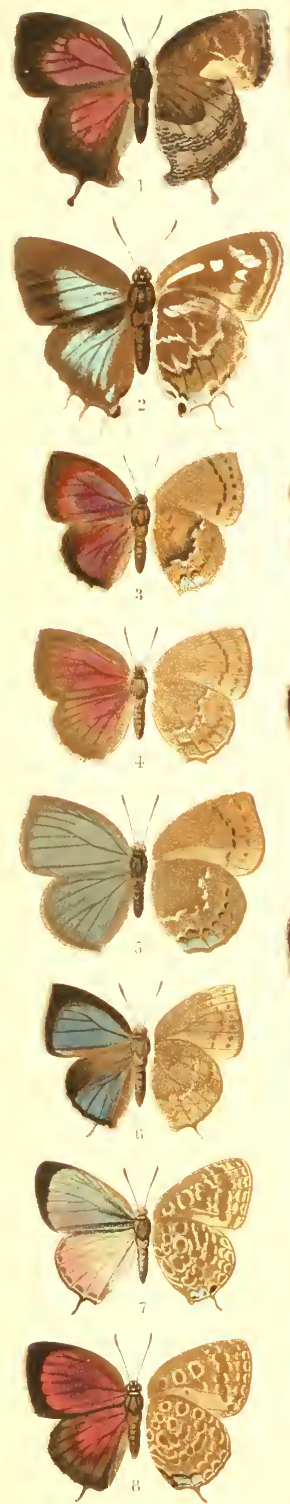
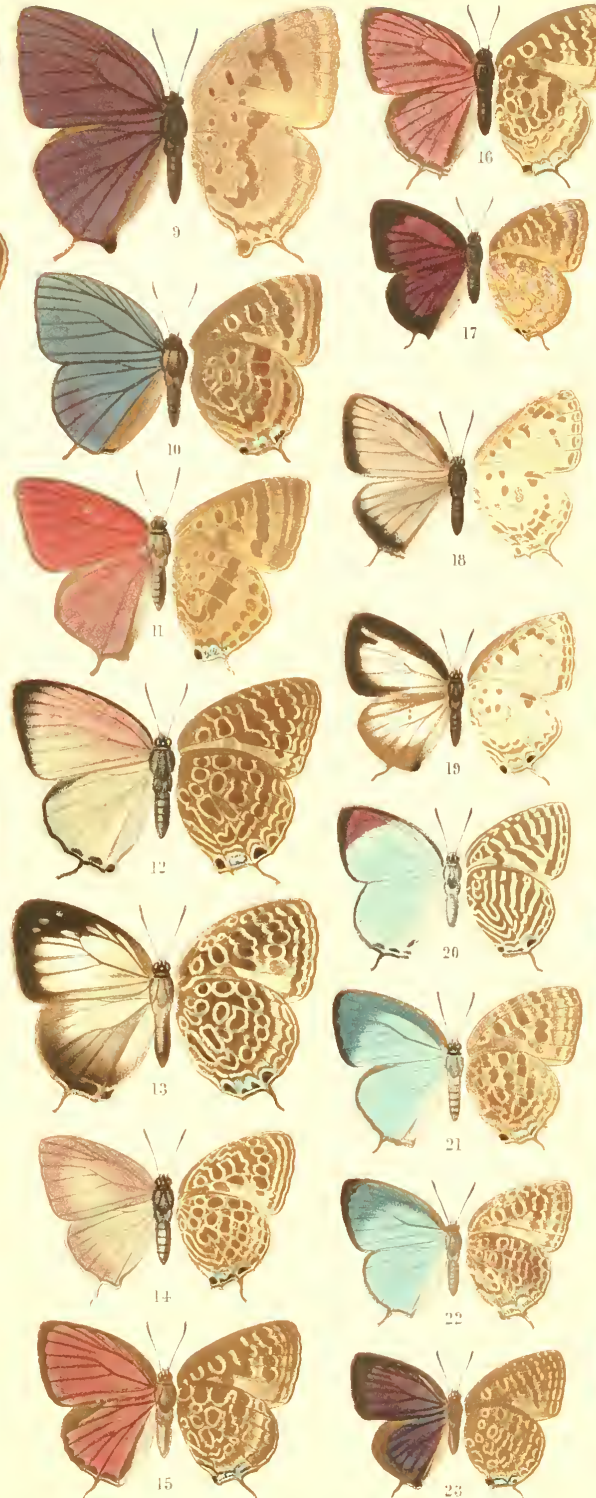
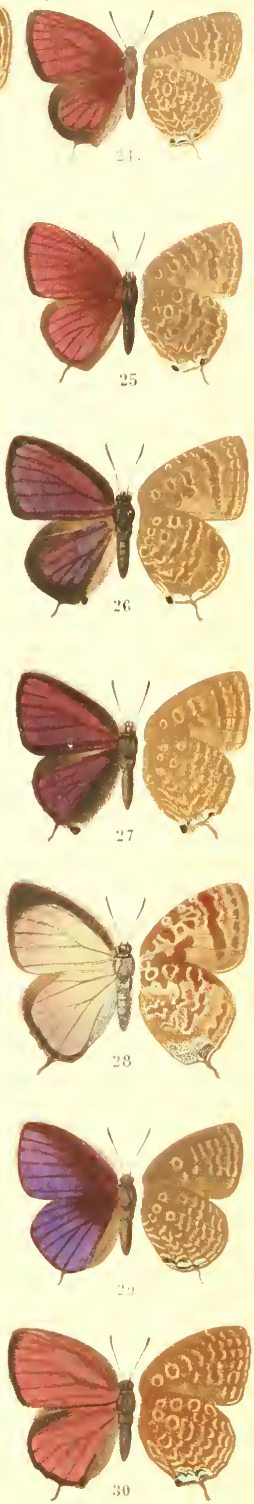


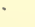




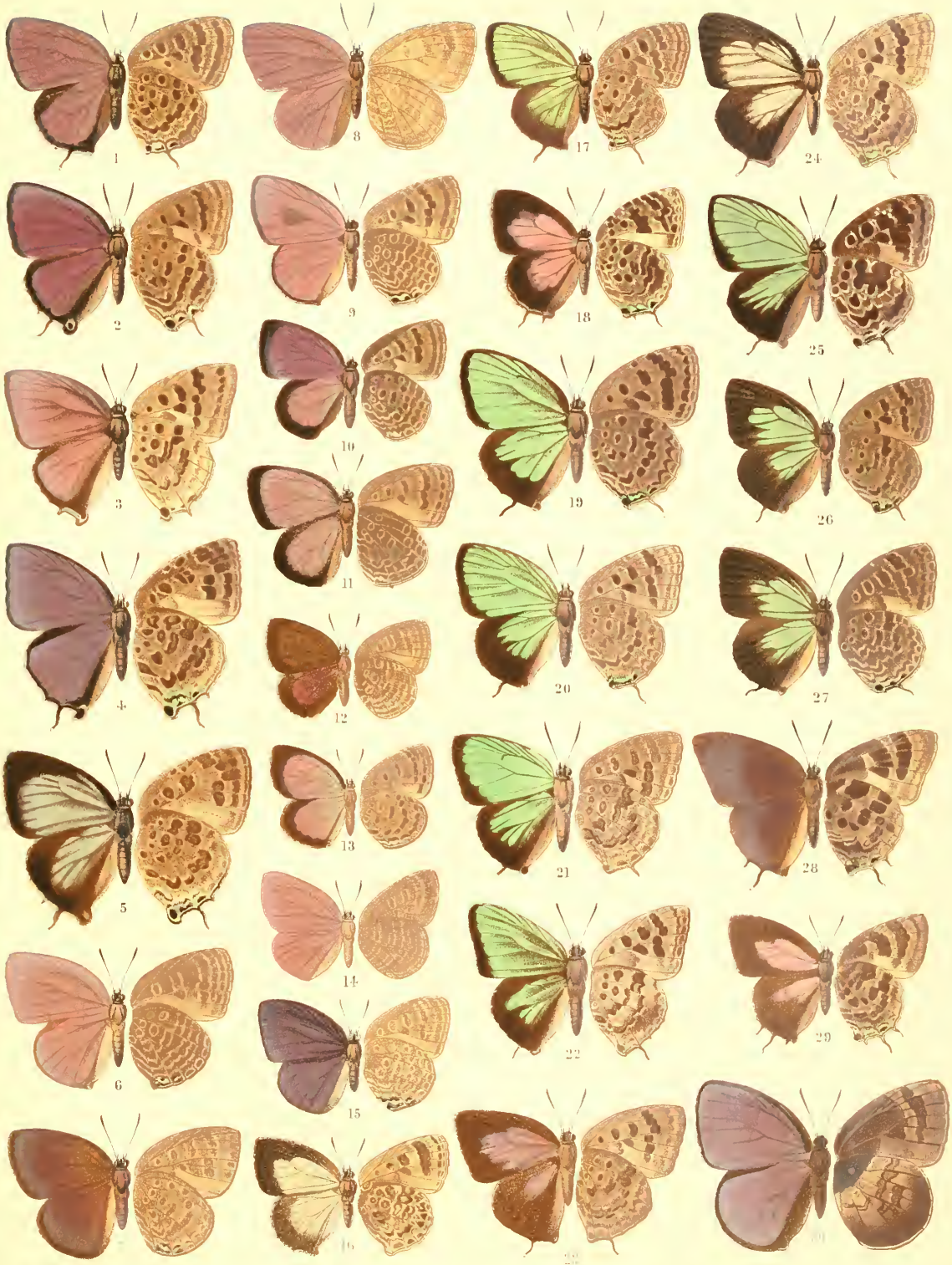




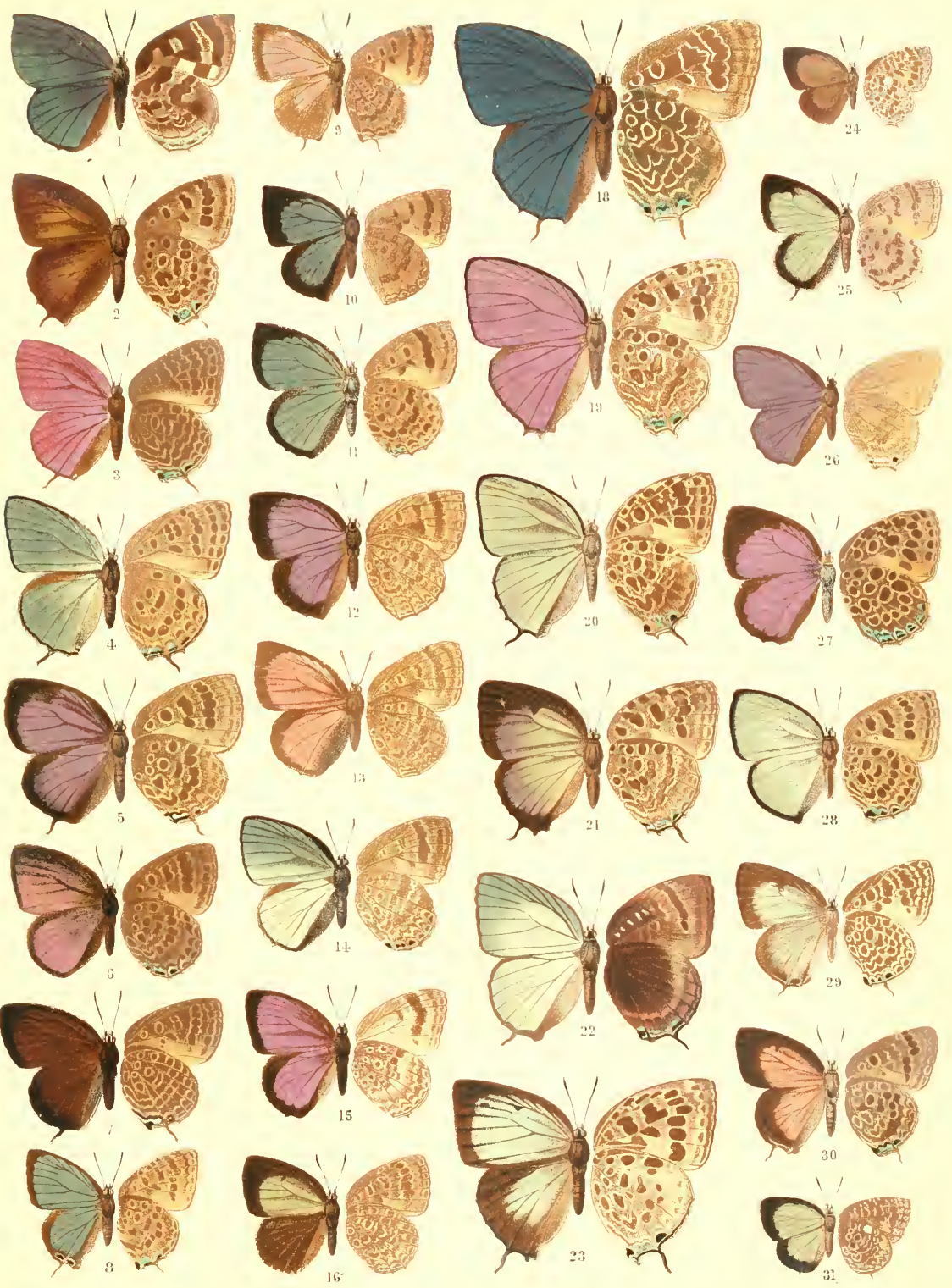




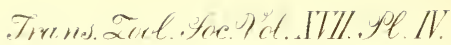
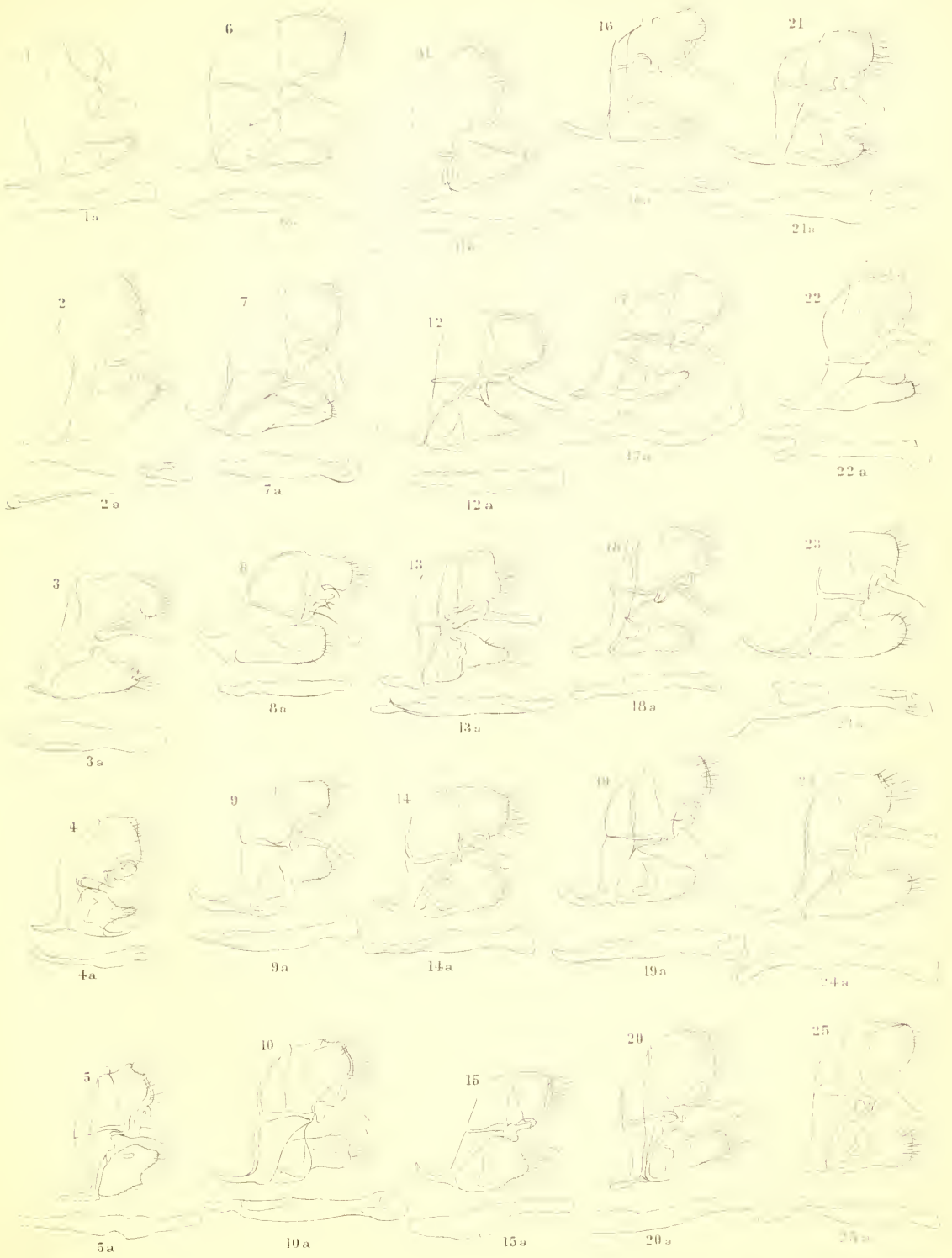

25

Wilutass th

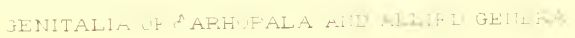




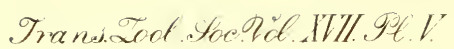
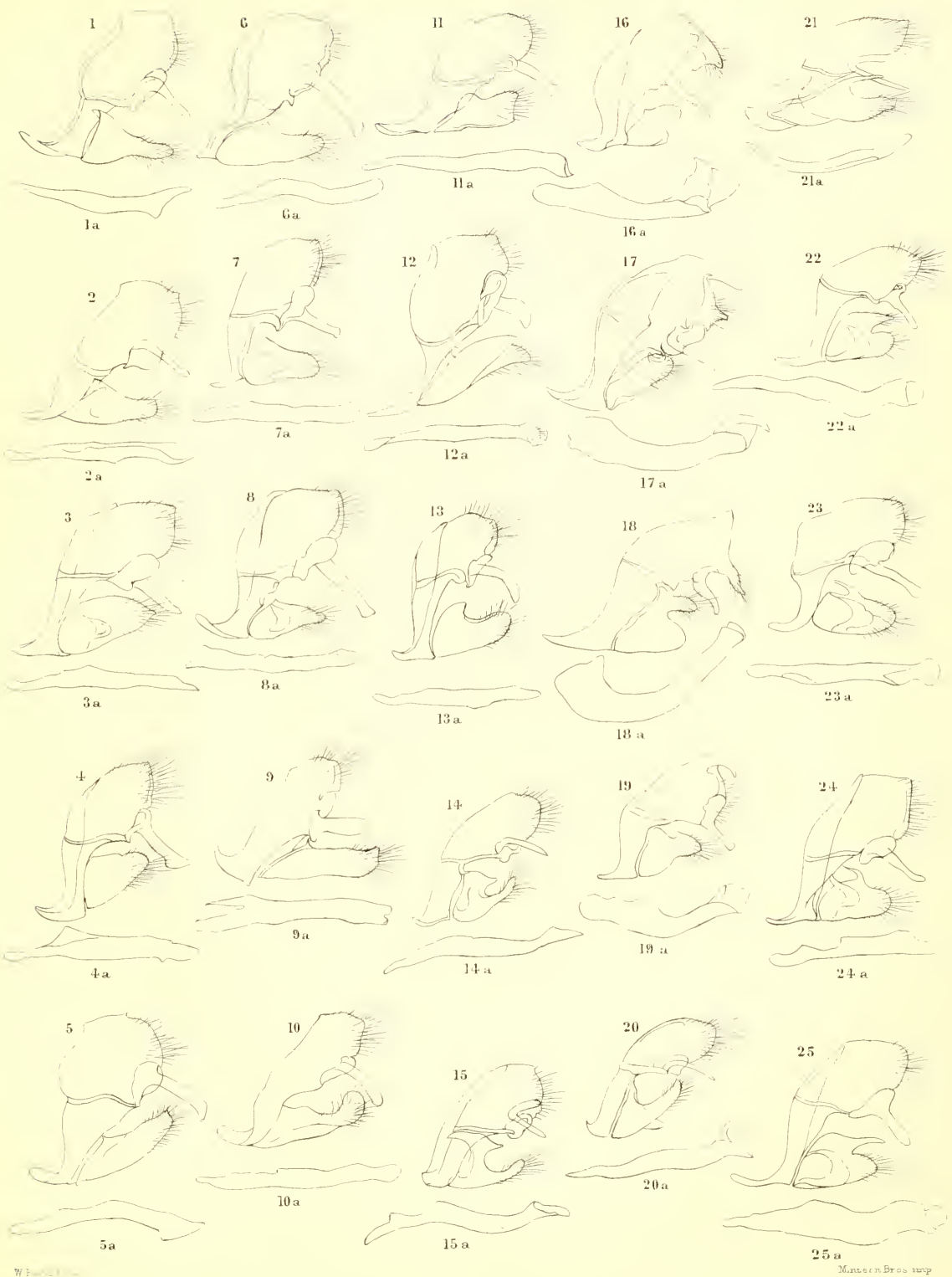

GENITALIA OF d ARHOPALA AND ALLIED GENERA 


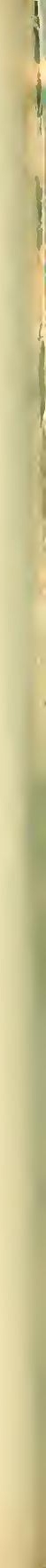




\section{TRANSACTIONS OF THE ZOOLOGICAL SOCIETY OF LONDON}

(continued).

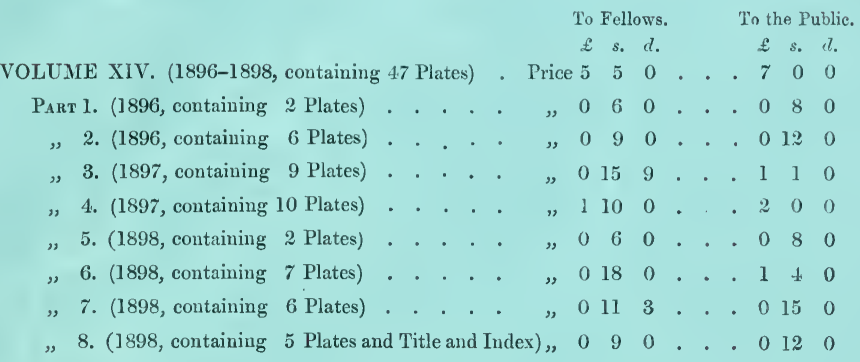

VOLUME XV. (1898-1901, containing 52 Plates) . Price 5156 . . 7140

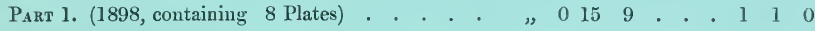

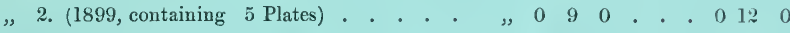

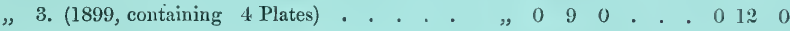

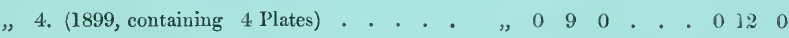

„5. (1900, containing 24 Plates) . . . . " " 2126 . . . 3100

"6. (1901, containing 4. Plates) . . . . „ $0113 \ldots 0.0150$

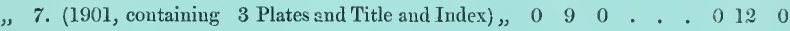

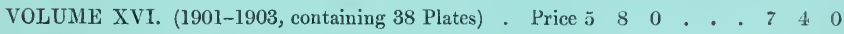

PARt 1. (1901, containing 6 Plates) . . . . , 0180 . . 1 \& 0

„2. (1901, containing 5 Plates) . . . . „, 0113 . . 0150

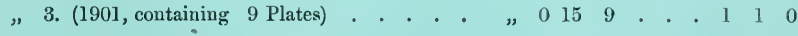

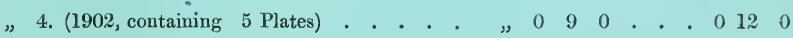

„5. (1902, containing 4 Plates) . . . . „ 0136 . . . 0180

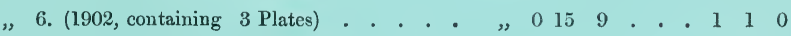

” 7. (1902, containing 3 Plates) . . . . „ 0113 . . . 0150

„8. (1903, containing 3 Plates andTitle and Index), 0136 . . . 0180

VOLUME XVII.

PART 1. (1903, containing 5 Plates) . . . Price 126 . . 1100 


\section{CONTENTS.}

I. A Revision of the Amblyodia Group of Butterfies of the Family Lrcenide. By George T. Bethune-Baker, F.L.S., F.Z.S., \&c. (Plates I.-V.). . . page 1

THE PUBLICATIONS OF THE ZOOLOGICAL SOCIETY OF LONDON.

THE scientific publications of the Zoological Society of London are of two kinds- "Proceedings," published in an octavo form, and "Transactions," in quarto.

According to the present arrangements, the "Proceedings" contain not only notices of all business transacted at the scientific meetings, but also all the papers read at such meetings and recommended to be published in the "Proceedings" by the Committee of Publication. A large number of coloured plates and engravings are attached to each annual volume of the "Proceedings," to illustrate the new or otherwise remarkable species of animals described in them. Among such illustrations, figures of the new or rare species acquired in a living state for the Society's Gardens are often given.

The "Proceedings" for eacl year are issued in four parts, in the months of June, August, October, and April, the part published in April completing the volume for the last half of the preceding year. Beginning from January 1901 they form two half-yearly volumes.

The "Transactions" contain such of the more important communications made to the scientific meetings of the Society as, on account of the nature of the plates required to illustrate them, are better adapted for publication in the quarto form. They are issued at irregular intervals.

Fellows and Corresponding Members, upon payment of a Subscription of $£ 1$ s. before the day of the Anniversary Meeting in each year, are entitled to receive all the Society's Publications for the year. They are likewise entitled to purchase the Publications of the Society at 25 per cent. less than the price charged for them to the Public. A further reduction of 25 per cent. is made upon purchases of Publications issued prior to 1871, if they exceed the value of five pounds.

Fellows also have the privilege of subscribing to the Annual Volume of the 'Zoological Record' for a sum of $\mathfrak{\ell l}$ (which includes delivery in the United Kingdom only), but this privilege only holds good if the subscription is paid before the First of December in each year.

Such of these publications as are in stock may be obtained at the Society's Office (3 Hanover Square, W.), at Messrs. Longmans', the Society's publishers (Paternoster Row, E.C.), or through any bookseller.

August, 1903.

P. CHALMERS MITCHELL, Secretary. 



(n) 3. 3.53

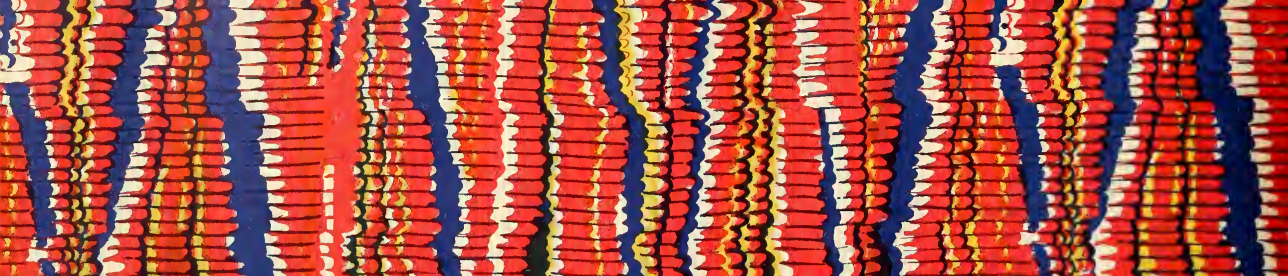

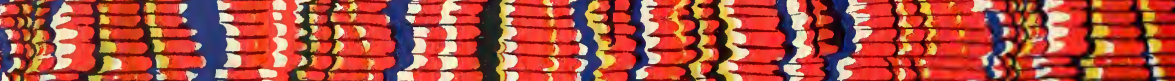

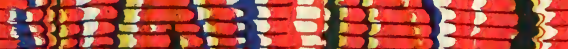
$-3,2+25: 5=3$

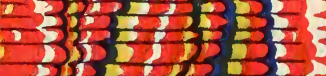

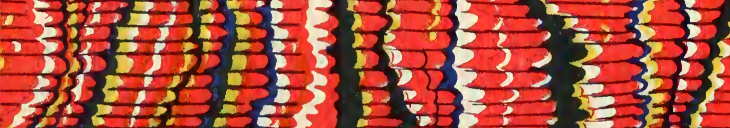

$-3 \frac{12}{32}$

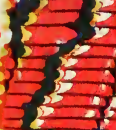

है

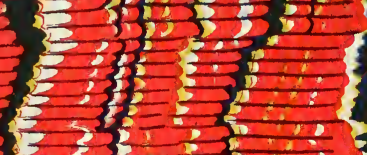
$T_{2} x^{2}-33^{2}$

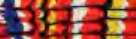

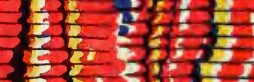
है: $30,2>3$

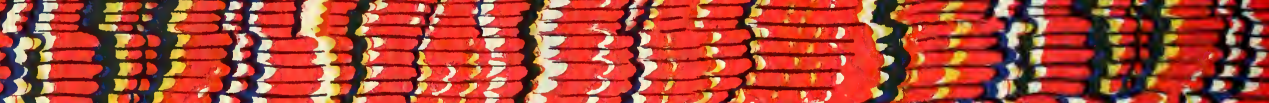

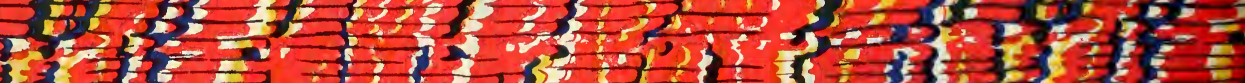

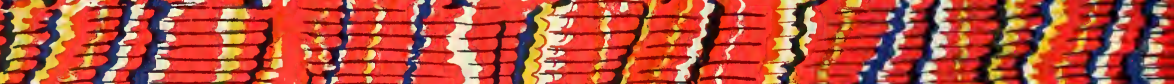

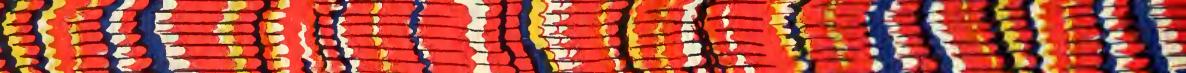

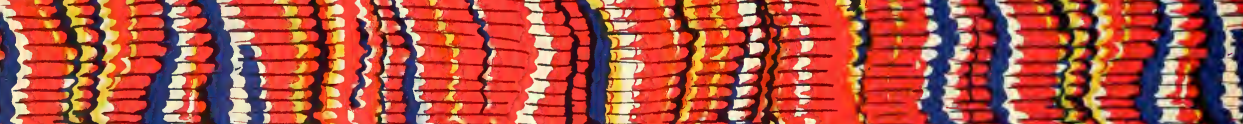

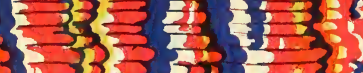

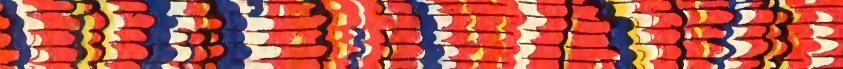


